\title{
TSUNAMI INUNDATION MAPS FOR KING COVE AND COLD BAY COMMUNITIES, ALASKA
}

\author{
E.N. Suleimani, D.J. Nicolsky, R.D. Koehler, J.T. Freymueller, and A.E. Macpherson
}

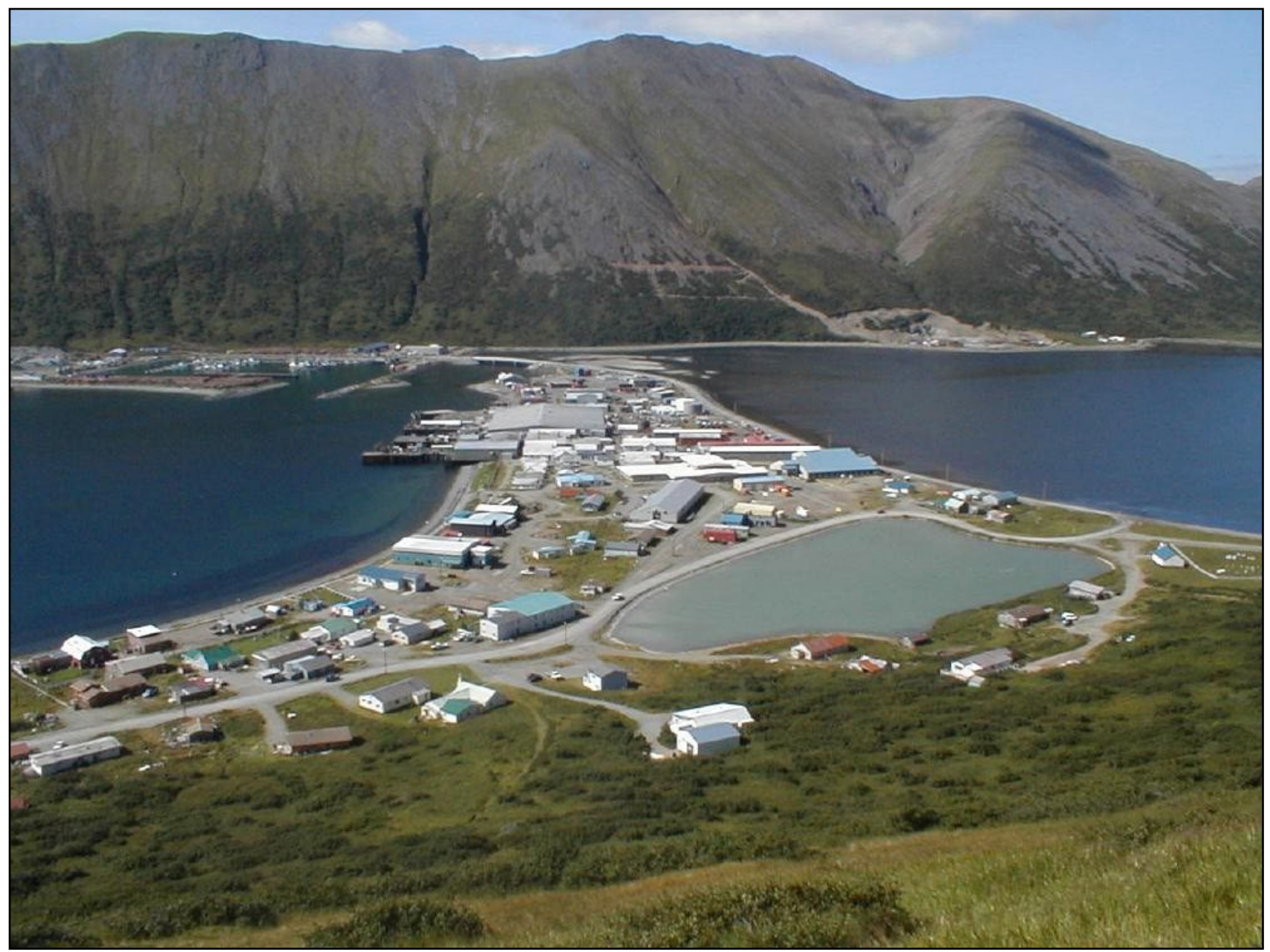

View, looking west, of King Cove, Alaska. Boat Harbor Service Road provides vehicle access across King Cove Lagoon to West Lagoon Road. According to the report, this area is likely to be inundated by a future tsunami. Photo courtesy of www.city-data.com.

\section{Published by}

STATE OF ALASKA

DEPARTMENT OF NATURAL RESOURCES

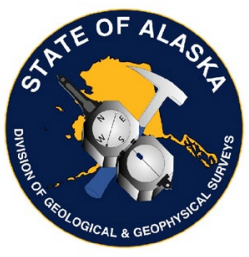

DIVISION OF GEOLOGICAL \& GEOPHYSICAL SURVEYS 



\section{TSUNAMI INUNDATION MAPS FOR KING COVE AND COLD BAY COMMUNITIES, ALASKA}

E.N. Suleimani, D.J. Nicolsky, R.D. Koehler, J.T. Freymueller, and A.E. Macpherson Report of Investigations 2016-1

State of Alaska

Department of Natural Resources

Division of Geological \& Geophysical Surveys 


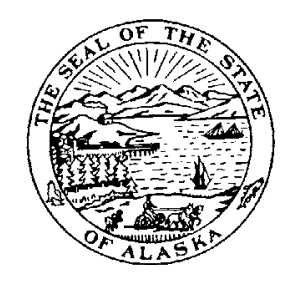

STATE OF ALASKA

Bill Walker, Governor

\section{DEPARTMENT OF NATURAL RESOURCES}

Marty Rutherford, Acting Commissioner

\section{DIVISION OF GEOLOGICAL \& GEOPHYSICAL SURVEYS}

Steve Masterman, State Geologist and Director

Publications produced by the Division of Geological \& Geophysical Surveys (DGGS) are available for free download from the DGGS website (www.dggs.alaska.gov). Publications on hard-copy or digital media can be examined or purchased in the Fairbanks office:

\section{Alaska Division of Geological \& Geophysical Surveys 3354 College Rd., Fairbanks, Alaska 99709-3707 \\ Phone: (907) 451-5010 Fax (907) 451-5050 \\ dggspubs@alaska.gov www.dggs.alaska.gov}

Alaska State Library

State Office Building, 8th Floor 333 Willoughby Avenue

Juneau, Alaska 99811-0571
Alaska Resource Library \& Information

Services (ARLIS)

3150 C Street, Suite 100

Anchorage, Alaska 99503-3982 


\section{CONTENTS}

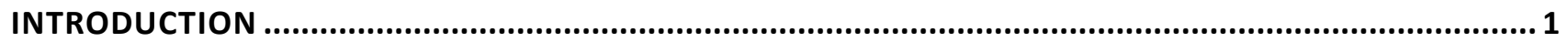

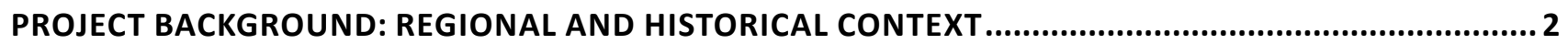

Setting

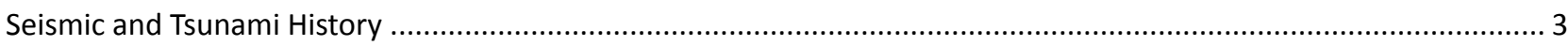

Landslide-Generated Tsunami Hazards in King Cove and Cold Bay....................................................................

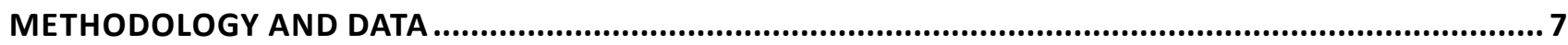

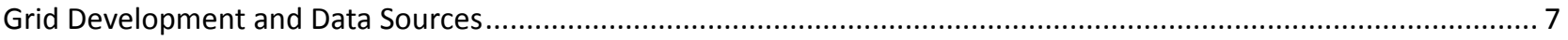

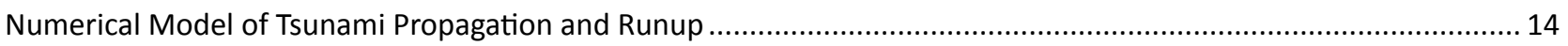

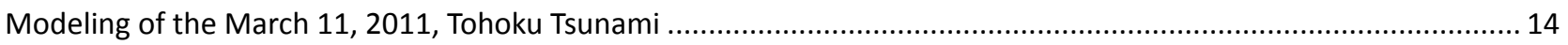

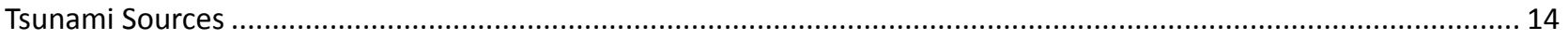

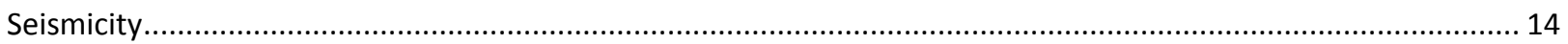

Geodetic studies

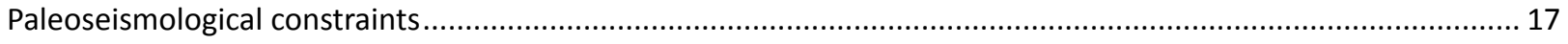

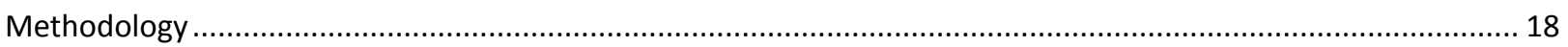

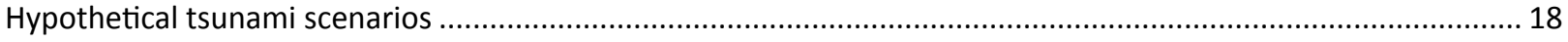

Scenario 1. $M_{W} 9.1$ earthquake in the western Alaska Peninsula region: Two asperities and trench ................ 18

Scenario 2. $M_{W} 9.1$ earthquake in the western Alaska Peninsula region: Two asperities, weakly

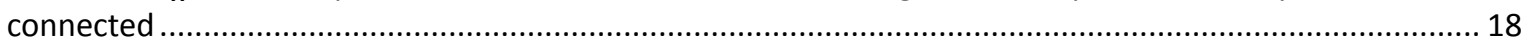

Scenario 3. $M_{W} 8.9$ earthquake in the western Alaska Peninsula region: Eastern asperity and trench ............. 20

Scenario 4. $M_{W} 9.0$ earthquake in the western Alaska Peninsula region: Western asperity and trench............ 20

Scenario 5. $M_{W} 8.6$ earthquake in the western Alaska Peninsula region: Eastern asperity only ...................... 20

Scenario 6. $M_{w} 8.3$ earthquake in the western Alaska Peninsula region: Western asperity only ...................... 21

Scenario 7. $M_{W} 8.9$ earthquake in the western Alaska Peninsula region: Gap-filling event ............................. 32

Scenario 8. $M_{W} 9.0$ earthquake in the western Alaska Peninsula region: Predominantly shallow slip in

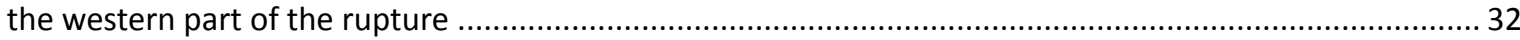

Scenario 9. $M_{w} 9.1$ earthquake in the western Alaska Peninsula region: Predominantly shallow slip in

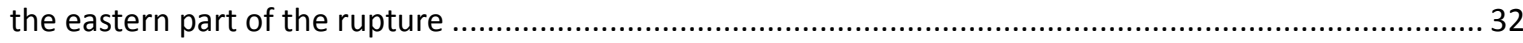

Scenario 10. $M_{W} 9.2$ earthquake in the western Alaska Peninsula region ..................................................... 32

Scenario 11. $M_{W} 9.3$ earthquake in the western Alaska Peninsula region ..................................................... 32

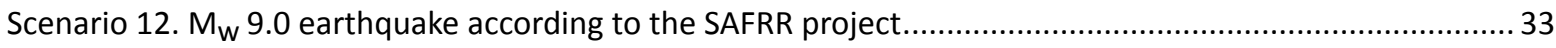

Scenario 13. $M_{W} 9.0$ earthquake in the western Alaska Peninsula region: SAFRR-type event.......................... 33

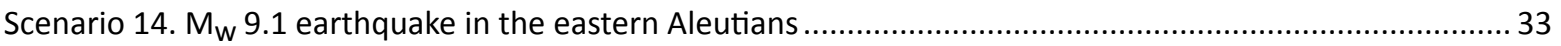

Scenario 15. Rupture of the tensional outer-rise part of the subduction plate south of the trench in the

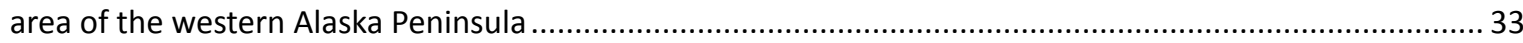

Scenario 16. Rupture of the Cascadia zone including the entire megathrust between British Columbia and

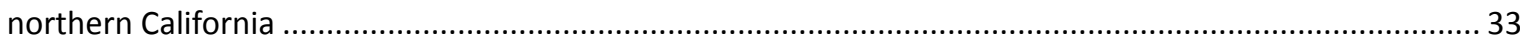

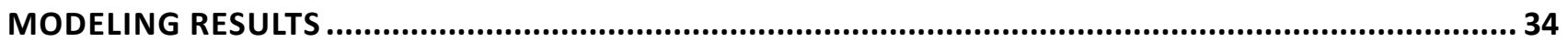

King Cove

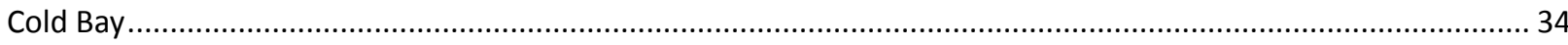

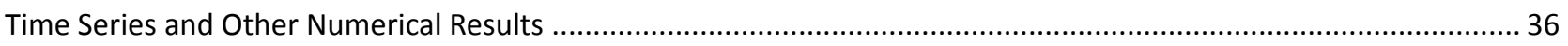

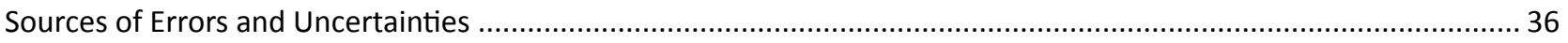

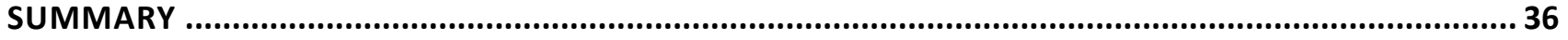

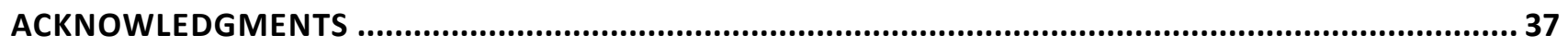

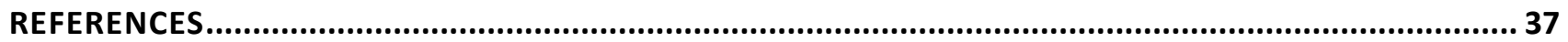




\section{FIGURES}

Figure 1. Map of the eastern Aleutian Islands and Alaska Peninsula .............................................................. 2

2. Map of western Alaska Peninsula and Unimak Island, showing the locations of the communities of King Cove and Cold Bay.

3. Earthquakes along the Alaska Peninsula and Aleutian Islands, 1980-2013, from the Alaska Earthquake Center catalog.

4. Map of the continental slope near Unimak Island that shows location of Lone Knoll relative to Scotch Cap.

5. Bathymetry map of Lone Knoll

6. Nesting of the bathymetry/topography grids for numerical modeling of tsunami propagation and

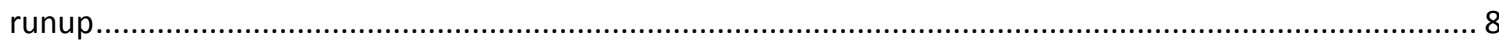

7. Locations of RTK (real-time kinematic) GPS measurements at King Cove and Cold Bay.....

8. Predicted water-level dynamics and fitted GPS measurements of the water level in the MHHW datum for King Cove and Cold Bay

9. Vertical deformations of the ocean floor and adjacent coastal region corresponding to the March 11, 2011, Tohoku earthquake

10. Observed and simulated water-level dynamics at the King Cove tide station during the March 11, 2011, Tohoku tsunami.

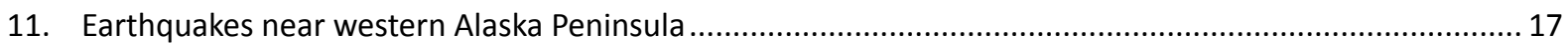

12. Discretization of the plate interface model to compute the coseismic vertical displacement................... 19

13. Mosaic of the plate interface in the study area used for the construction of hypothetical ruptures ..........20

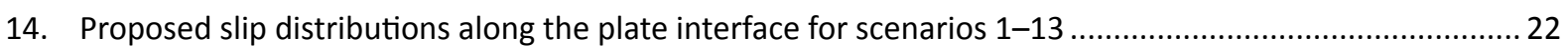

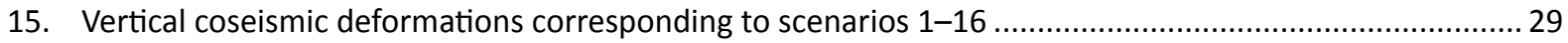

16. Modeled potential inundation in King Cove by tectonic waves for all scenarios that result in a significant inundation.

\section{TABLES}

Table 1. Nested grids used to compute propagation of tsunami waves generated in the Pacific Ocean to the communities of King Cove and Cold Bay.....

2. All hypothetical scenarios used to model tsunami runup in King Cove and Cold Bay..............................21

3. Fault parameters for the hypothetical tensional Mw 8.6 outer-rise earthquake ......................................3 33 


\section{APPENDICES}

APPENDIX A: KING COVE

Figure A-1. Maps showing locations of time series points in King Cove

Table A-1. Maximum water levels at time series points in King Cove...

A-2. Maximum water velocities at time series points in King Cove

Figure A-2. Graphs showing time series of water level and velocity for selected locations in King Cove for scenarios 2, 4, 5, 7, and 8

A-3. Graphs showing time series of water level and velocity for selected locations in King Cove for scenarios 10,13,14, 15, and 16

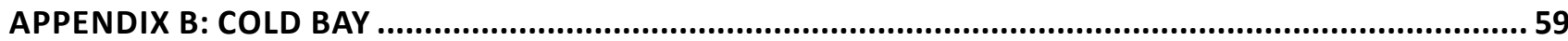

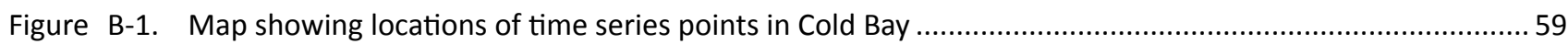

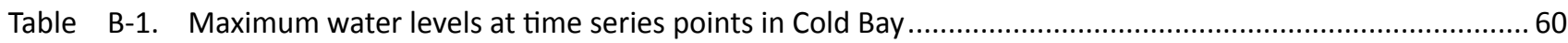

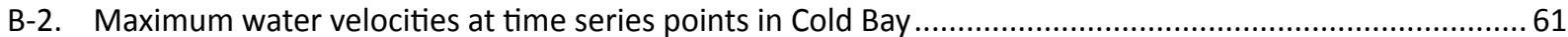

Figure B-2. Graphs showing time series of water level and velocity for selected locations in Cold Bay for scenarios 2, 4, 5, 7 and 8 .

B-3. Graphs showing time series of water level and velocity for selected locations in Cold Bay for scenarios $10,13,14,15$ and 16

APPENDIX C: KING COVE AND COLD BAY 74

Figure C-1. Map showing potential maximum permanent flooding in King Cove. Values of subsidence corresponding to each scenario are listed in table 2 .

C-2. Map showing potential maximum permanent flooding in Cold Bay. Values of subsidence corresponding to each scenario are listed in table 2 .

\section{SHEETS}

Sheet 1. Maximum estimated tsunami inundation, King Cove, Alaska

2. Maximum estimated tsunami inundation, Cold Bay, Alaska 



\title{
TSUNAMI INUNDATION MAPS FOR KING COVE AND COLD BAY COMMUNITIES, ALASKA
}

\author{
E.N. Suleimani ${ }^{1}$, D.J. Nicolsky ${ }^{1}$, R.D. Koehler ${ }^{2}$, J.T. Freymueller ${ }^{1}$, and. A.E. Macpherson ${ }^{1}$
}

\begin{abstract}
Potential tsunami hazards for the Alaska Peninsula communities of King Cove and Cold Bay were evaluated by numerically modeling the extent of inundation from tsunami waves generated by hypothetical earthquake sources and taking into account historical observations. Worst-case hypothetical scenarios are defined by analyzing the tsunami dynamics related to various slip distributions along the Aleutian megathrust. Our results show that the worst-case scenarios for King Cove and Cold Bay are thrust earthquakes in the western Alaska Peninsula region, with magnitudes ranging from $M_{w} 8.9$ to $M_{W} 9.3$, which have their greatest slip at 10-20 km (6-12 mi) depth. We also consider Tohoku-type ruptures and an outer-rise rupture in the western Alaska Peninsula area. Results presented here are intended to provide guidance to local emergency management agencies in tsunami inundation assessment, evacuation planning, and public education to mitigate future tsunami hazards.
\end{abstract}

\section{INTRODUCTION}

Subduction of the Pacific plate under the North American plate has resulted in numerous great earthquakes and has the highest potential to generate tsunamis in Alaska (Dunbar and Weaver, 2008). The Aleutian megathrust (fig. 1), the fault formed by the Pacific-North American plate interface, is a seismically active tsunamigenic fault zone. The latest sequence of great earthquakes along the Aleutian megathrust began in 1938 with a $\mathrm{M}_{\mathrm{w}} 8.3$ earthquake west of Kodiak Island (Estabrook and others, 1994). Four subsequent events, the $1946 \mathrm{M}_{\mathrm{W}} 8.6$ Aleutian (Lopez and Okal, 2006), the $1957 \mathrm{M}_{\mathrm{W}} 8.6$ Andreanof Island (Johnson and Satake, 1993), the $1964 \mathrm{M}_{\mathrm{W}} 9.2$ Alaska (Kanamori, 1970), and the $1965 \mathrm{M}_{\mathrm{W}} 8.7$ Rat Island (Wu and Kanamori, 1973) earthquakes, ruptured almost the entire length of the megathrust. Tsunamis generated by these great earthquakes reached Alaska coastal communities within minutes after the earthquakes and resulted in widespread damage and loss of life (National Centers for Environmental Information/World Data Service [NCEI/WDS]). Saving lives and property depends on how well a community is prepared, which further depends on estimating potential flooding of the coastal zone in the event of a local or distant tsunami.

On April 1, 1946, the eastern Aleutian Islands were struck by a $M_{W} 8.6$ megathrust earthquake, which initiated near Unimak Island (fig. 1). This earthquake generated a major destructive far-field tsunami in the Pacific Ocean that reached Antarctica (Lander, 1996). The tsunami killed 159 people in Hawai'i and caused damage in California, Oregon, and Washington before traveling to such distant countries as Chile, Japan, French Polynesia, New Zealand, and other areas of the Pacific (NCEI/WDS). In Alaska this event produced an extremely high runup of $42 \mathrm{~m}$ (138 ft) on the Pacific shore of Unimak Island, destroying the lighthouse at Scotch Cap (Okal and others, 2002). The communities of King Cove and Cold

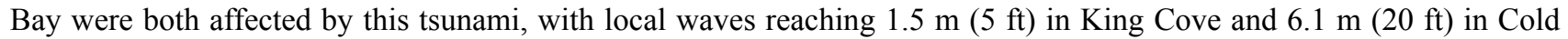
Bay (Lander, 1996). To help planners mitigate the risk from potential future earthquakes and tsunamis, it is necessary to develop inundation and tsunami evacuation maps they can use. In this report, we provide an analysis of the tsunami hazard and develop tsunami inundation maps for the communities of King Cove and Cold Bay.

The methodologies used to develop tsunami inundation maps are described in detail in multiple publications. Refer to Suleimani and others $(2010,2013,2015)$ and Nicolsky and others (2011a, 2013, 2014, 2015) for a full description of the procedure. First we develop hypothetical tsunami scenarios on the basis of credible potential tsunamigenic earthquakes. Then we perform model simulations for each of these scenarios and compare the results with historical tsunami observations, if available. Finally we develop a "worst case" inundation line that encompasses the maximum extent of flooding based on model simulation of all credible source scenarios and historical observations. The worst-case inundation line becomes a basis for local tsunami hazard planning and development of evacuation maps.

This report is intended for use by scientists, engineers, and planners interested in applying modeling based on historic events to develop tsunami inundation and evacuation maps. Digital data and documentation provided with the report enable technical users to explore the range of tsunami inundation expected for future events.

\footnotetext{
${ }^{1}$ Alaska Earthquake Center, Geophysical Institute, University of Alaska, P.O. Box 757320, Fairbanks, AK 99775-7320; ensuleimani@alaska.edu ${ }^{2}$ Alaska Division of Geological \& Geophysical Surveys, 3354 College Rd., Fairbanks, AK 99709-3707; now at Nevada Bureau of Mines and Geology, Mackay School of Earth Science and Engineering, University of Nevada, Reno, 1664 North Virginia Street, MS 178, Reno, NV 89557
} 


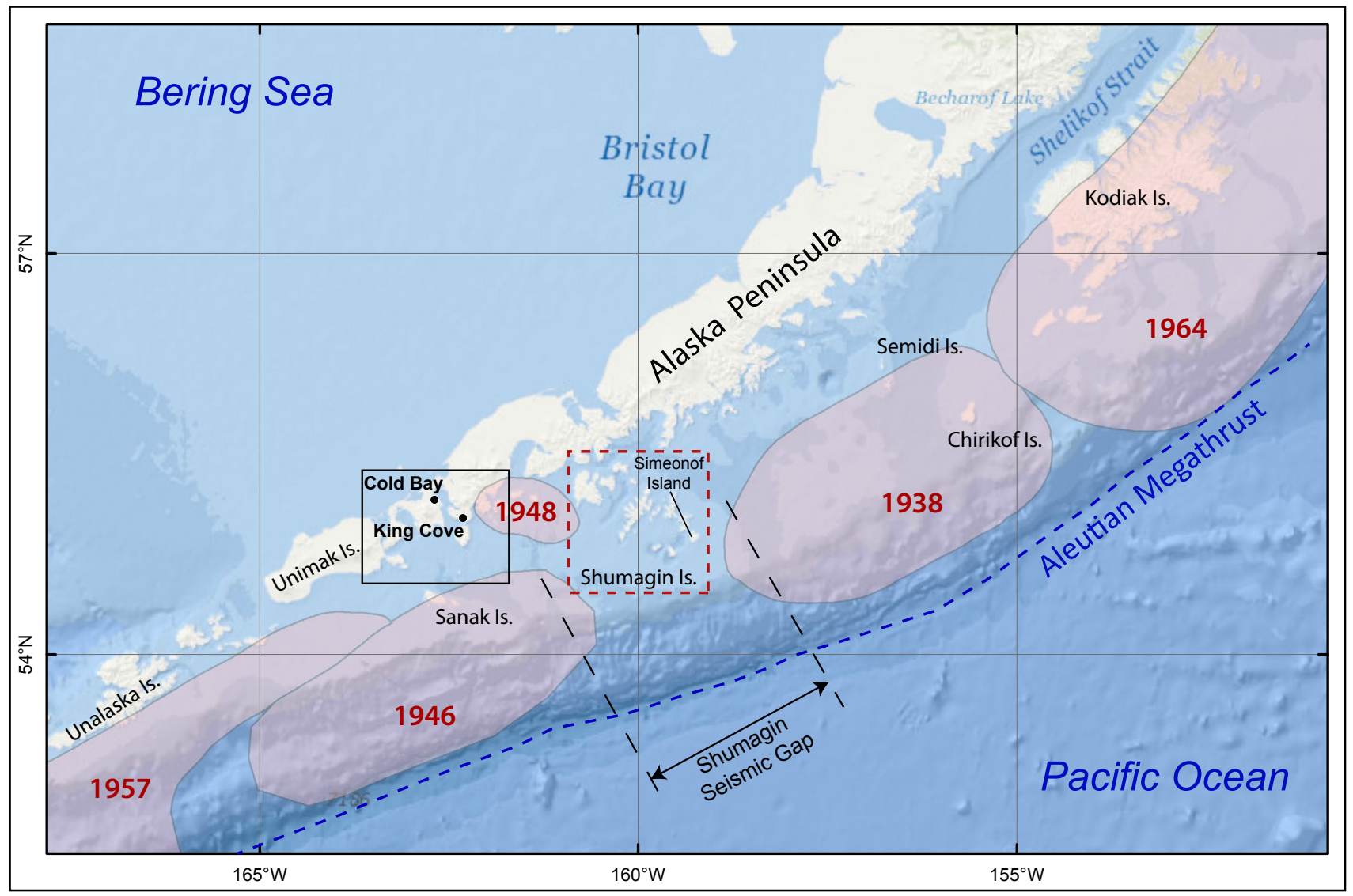

Figure 1. Map of the eastern Aleutian Islands and Alaska Peninsula. Shaded polygons delineate rupture areas of great earthquakes and are based on distribution of aftershocks. The dashed red rectangle marks the Shumagin Archipelago. The black rectangle outlines the study area, which is shown in detail in figure 2.

\section{PROJECT BACKGROUND: REGIONAL AND HISTORICAL CONTEXT}

\section{SETTING}

The community of King Cove $\left(55^{\circ} 04^{\prime} 20^{\prime \prime} \mathrm{N}, 162^{\circ} 19^{\prime} 05^{\prime \prime} \mathrm{W}\right)$, population 792 , is on the Pacific side of the Alaska Peninsula on a sand spit fronting Deer Passage and Deer Island (figs. 1 and 2). It is $30 \mathrm{~km}$ (18.6 mi) southeast of Cold Bay and $1,005 \mathrm{~km}$ (625 mi) southwest of Anchorage. According to the Alaska Department of Commerce, Community, and Economic Development (Division of Community and Regional Affairs [DCRA], 2013b) King Cove was founded in 1911 when Pacific American Fisheries built a salmon cannery there. Early settlers were of Unangan, Scandinavian, and other European heritage. The city was incorporated in 1949 and the cannery operated continuously from 1911 to 1976 until partially destroyed in a fire. Today the town is home to Peter Pan Seafoods' largest processing facility and boasts the largest salmon canning capacity of any plant in Alaska. King crab, pollock, salmon, halibut, and black cod are processed here throughout the year. At peak seasons, in both winter and summer, nearly 500 employees staff the plant. The economy of King Cove depends almost entirely on year-round commercial fishing and processing. King Cove has no road access and is accessible by air and sea only. A state-owned gravel runway exists but gale force crosswinds are common, as the airport lies in a valley between two volcanic peaks. A proposed road connecting King Cove and Cold Bay would provide a more reliable link to the outside world during emergencies. A state ferry provides biweekly service to King Cove between May and October. A new harbor provides moorage for large vessels between 60 and 150 feet in length.

The small community of Cold Bay $\left(55^{\circ} 12^{\prime} 33^{\prime}\right.$ 'N $\left.162^{\circ} 42^{\prime} 51^{\prime \prime} \mathrm{W}\right)$, population 108, is in the Izembek National Wildlife Refuge at the western end of the Alaska Peninsula (figs. 1 and 2). The Izembek Refuge is between the highly productive waters of the Bering Sea and the Pacific Ocean and contains Izembek Lagoon, a unique coastal ecosystem with more than 200 species of wildlife. The community of Cold Bay is 1,020 km (634 mi) southwest of Anchorage and $290 \mathrm{~km}(180 \mathrm{mi})$ northeast of Unalaska. Archaeological sites dating to the last ice age indicate that the area around Cold Bay was once inhabited by a large Native population (DCRA, 2013a). It was used by European hunters and trappers throughout the 19th century. During World War II, Cold Bay was the site of the strategic air base Fort Randall. At that time, the airport was the largest in the state, with a $\sim 3,050 \mathrm{~m}(10,000 \mathrm{ft})$ runway. The city was incorporated in 1982 . Cold Bay services the fishing 


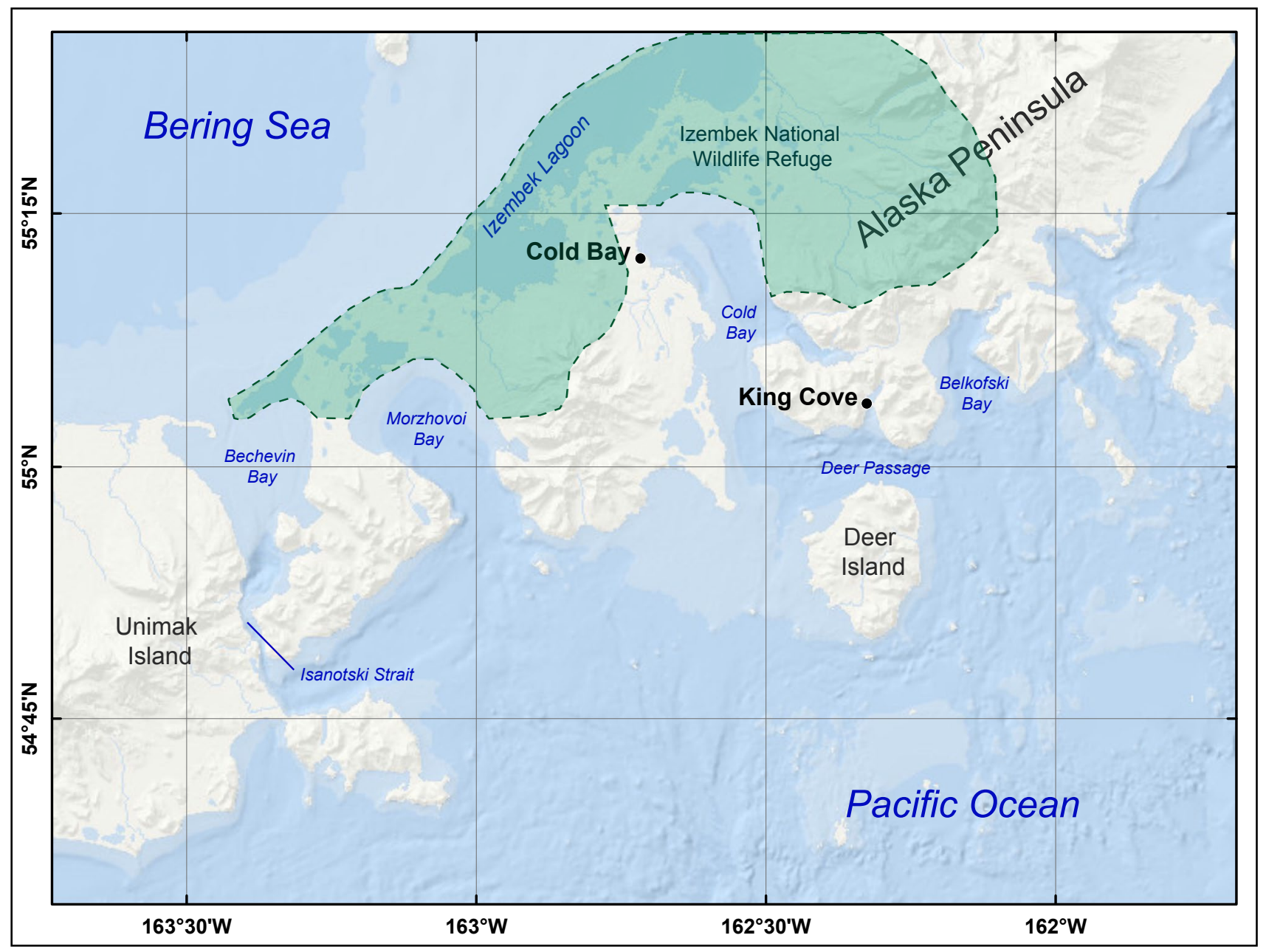

Figure 2. Map of western Alaska Peninsula and Unimak Island, showing the locations of the communities of King Cove and Cold Bay. The area shaded in green is the Izembek National Wildlife Refuge.

industry and houses a number of federal offices with services focused on Aleutian transportation and wildlife protection. Subsistence and recreational fishing and hunting are an important part of the local culture. Up to 70,000 Canada geese migrate through Cold Bay in the fall. Cold Bay is one of the main commercial centers of the Alaska Peninsula, and is home to Cold Bay Airport, a state-owned paved and lighted facility with a crosswind runway. Cold Bay is a regional transportation center and provides scheduled flights to surrounding communities. The community has a dock but wants to develop a breakwater, boat harbor, and boat launch. Marine cargo services are available monthly from Seattle, and the state ferry operates biweekly from Kodiak between May and October.

\section{SEISMIC AND TSUNAMI HISTORY}

The communities of King Cove and Cold Bay are at the western tip of the Alaska Peninsula, where this arcuate landform is separated by Bechevin Bay and the narrow Isanotski Strait from Unimak Island, the easternmost in a chain of Aleutian islands (fig. 2). This island arc constitutes the boundary along which the Pacific and North American tectonic plates converge and form the Alaska-Aleutian subduction zone (AASZ). The Shumagin archipelago of about 20 islands is in the same area (fig. 1). The rate of plate convergence near the archipelago is approximately 63-66 $\mathrm{mm}$ (2.5-2.6 in) per year (DeMets and others, 1990; Page and others, 1991; Argus and others, 2010), and the Alaska Peninsula segment of the Aleutian megathrust has produced some significant tsunamigenic earthquakes (shaded polygons in fig. 1). Refer to "Seismic and Tsunami History" in Nicolsky and others (in review) for a detailed description of these events and a summary of the tectonic regime in the Shumagin gap area.

Numerous earthquakes have been felt in the area where the communities of King Cove and Cold Bay are now located. Figure 3 shows seismic activity along the Alaska-Aleutian subduction zone with locations determined by the Alaska Earthquake Center (AEC) at the University of Alaska Fairbanks. Davies and others (1981) provide a regional map showing seismicity near the Shumagin Islands. Both Lander (1996) and the National Centers for Environmental Information (NCEI) Global Historical Tsunami Database list only one event in which King Cove and Cold Bay were affected by tsunami waves. 


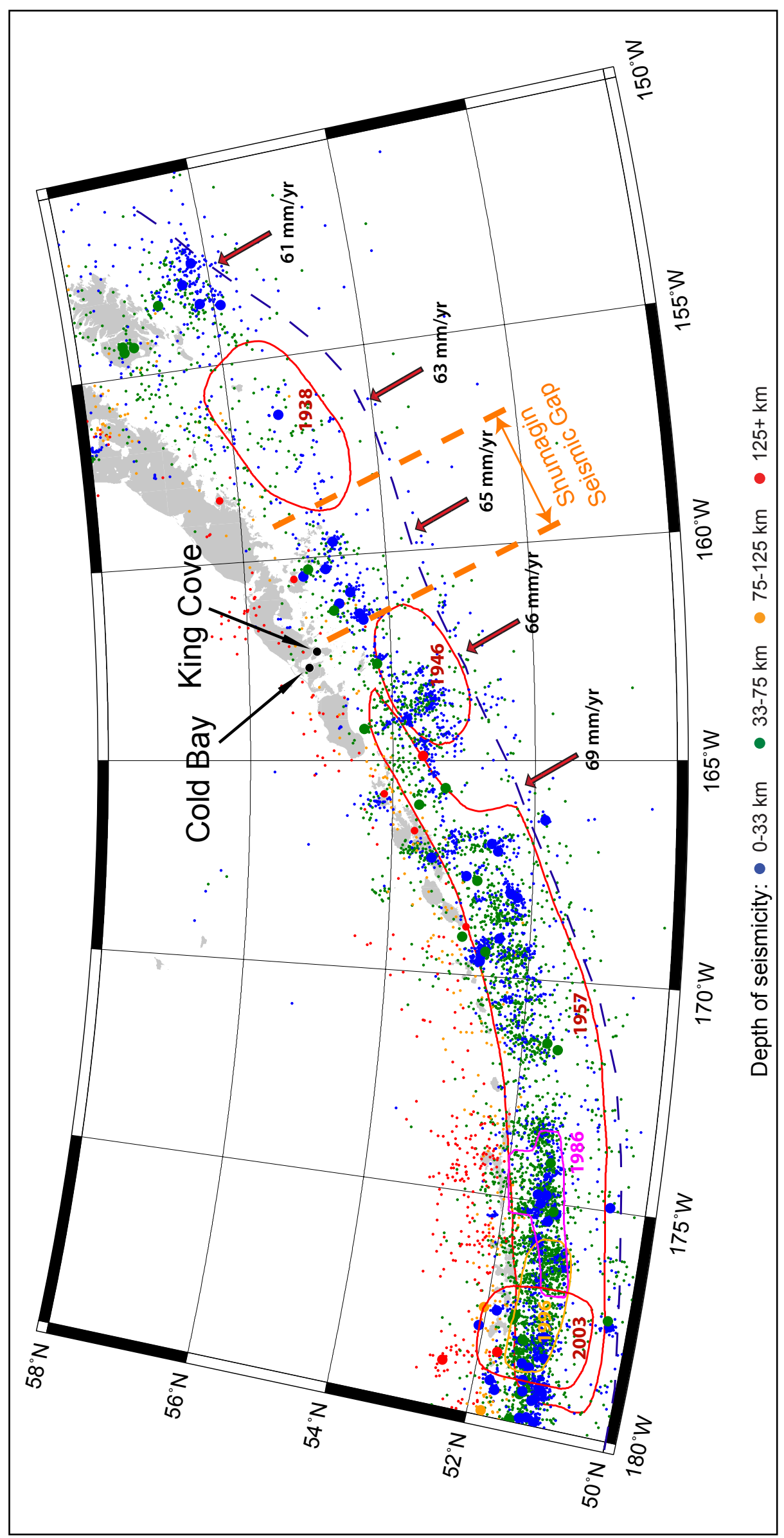

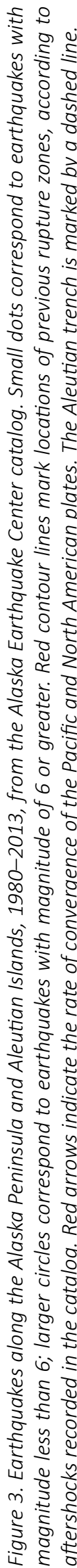


On April 1, 1946, a strong $\mathrm{M}_{\mathrm{W}} 8.6$ earthquake (Lopez and Okal, 2006) near Unimak Island triggered a major destructive

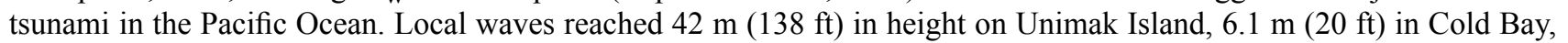

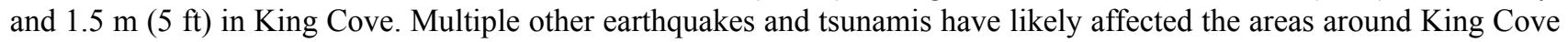
and Cold Bay; however, no records of events prior to 1946 are currently available.

Historical records, unfortunately, are usually too short to sample the variability of slip on the megathrust (Stein and Okal, 2007). Paleotsunami and paleoseismic studies have the potential to extend available historical records back in time and thus help to develop hypothetical maximum credible scenarios. In an effort to document tectonic deformation in the outer Shumagin Islands, Witter and others (2014) conducted a paleoseismic study on Simeonof Island (fig. 1), the island closest to the trench. This investigation determined that there was no evidence for sudden coseismic land-level changes produced by great earthquakes or any trace of marine deposits left by high tsunamis (Witter and others, 2014). The authors concluded that the lack of geologic evidence for great earthquakes and tsunamis on Simeonof Island indicates that aseismic slip may accommodate a substantial component of plate convergence along the Shumagin segment over the past 3,400 years. Witter and others (2014) suggested that large M 7-M 7.5 earthquakes might be sufficient to release the strain stored in the Shumagin gap. The implications of this geologic/paleoseismologic study on the development of the hypothetical tsunami scenarios are discussed later in the report.

\section{LANDSLIDE-GENERATED TSUNAMI HAZARDS IN KING COVE AND COLD BAY}

The destructive effects of tsunamis generated by subaerial and underwater slope failures have been identified previously in south-central and southeastern Alaska. See Suleimani and others $(2010,2015)$ and Nicolsky and others (2013) for an overview of primary causes and triggers of tsunamigenic landslides in Alaska. Several authors suggested a landslide component in the tsunami generation mechanism of the 1946 earthquake, for which the size of the tsunami was much larger than that estimated from the surface wave magnitude (Sykes, 1971; Johnson and Satake, 1997). Fryer and Watts (2001) proposed a particular sea floor feature that could have been the source of the large 1946 tsunami and could explain the exceptionally high local runup on Unimak Island. Recently von Huene and others (2014) analyzed a seismic reflection transect and multibeam bathymetric surveys in the area of the epicenter of the 1946 earthquake and discovered a large recent slide (a different feature than that proposed by Fryer and Watts [2001]), which they proposed as a candidate for the 1946 landslide tsunami source. This feature was called Lone Hill by Miller and others (2014); von Huene and others (2014) refer to it as Lone Knoll. Figure 4 shows the location of Lone Knoll relative to the epicenter of the 1946 earthquake, shown as a red star, and to Scotch Cap, where the $42 \mathrm{~m}$ (138 ft) tsunami runup destroyed the lighthouse (Lander, 1996). The area outlined by the black rectangle is also shown in detail in figure 5 as a high-resolution bathymetry image of the sea floor around Lone Knoll (from von Huene and others, 2014). The white dashed line in figure 5 is the proposed original location of Lone Knoll, from which it was detached. From analysis of seismic profiles and sea floor morphology, Lone Knoll was characterized as a translational slide that remained largely coherent due to its travel path across gently sloping and fluid-rich seafloor sediment (von Huene and others, 2014). These features may have contributed to the extreme wave runup on Unimak Island.

To assess landslide hazards in King Cove and Cold Bay and their potential contribution to tsunami hazards, one needs to complete site-specific slope-stability analyses (which cannot currently be completed for King Cove and Cold Bay because of insufficient data) that integrate geophysical, geological, and geotechnical data. While it is known that earthquakes have triggered major submarine mass movements in many places around the world (Mather and others, 2014; Lastras and others, 2013; Lee and others, 2006; Hance, 2003a, 2003b; Kulikov and others, 1998) and that numerical simulations of landslide-generated tsunamis are technically possible, more field data and scientific research are necessary to constrain the landslide sources before meaningful modeling results can be generated. Therefore, due to insufficient data on the locations and volumes of potential mass failures, in this report we do not model ${ }^{3}$ tsunamis generated by landslides.

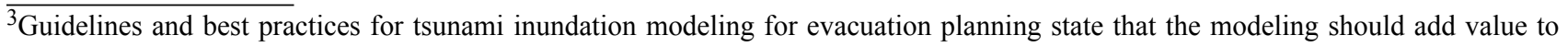
mapping products (National Tsunami Hazard Mapping Program [NTHMP], 2010).
} 


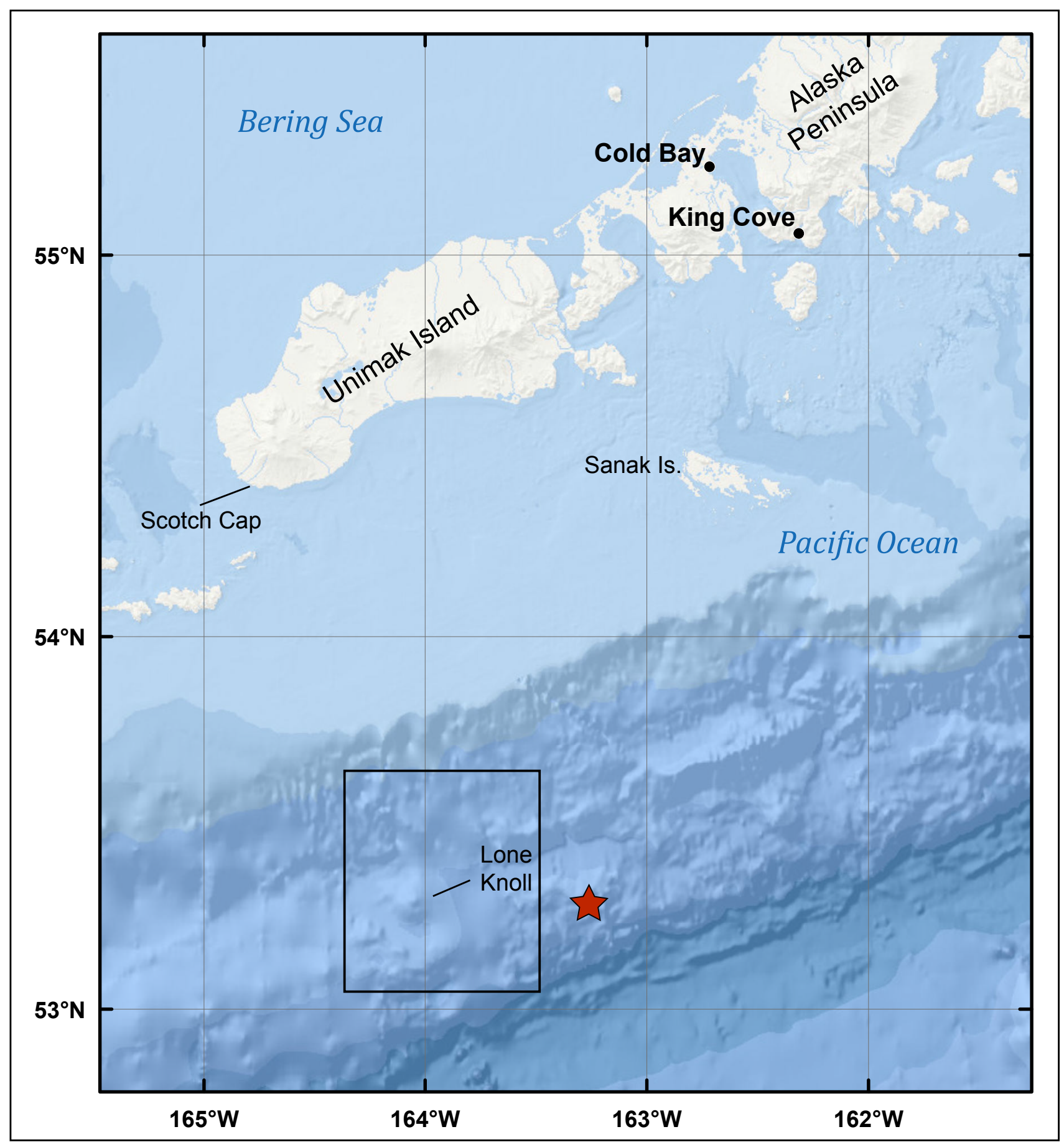

Figure 4. Map of the continental slope near Unimak Island that shows location of Lone Knoll relative to Scotch Cap. Red star indicates the epicenter of the 1946 earthquake, and black rectangle outlines area shown in detail in figure 5. 


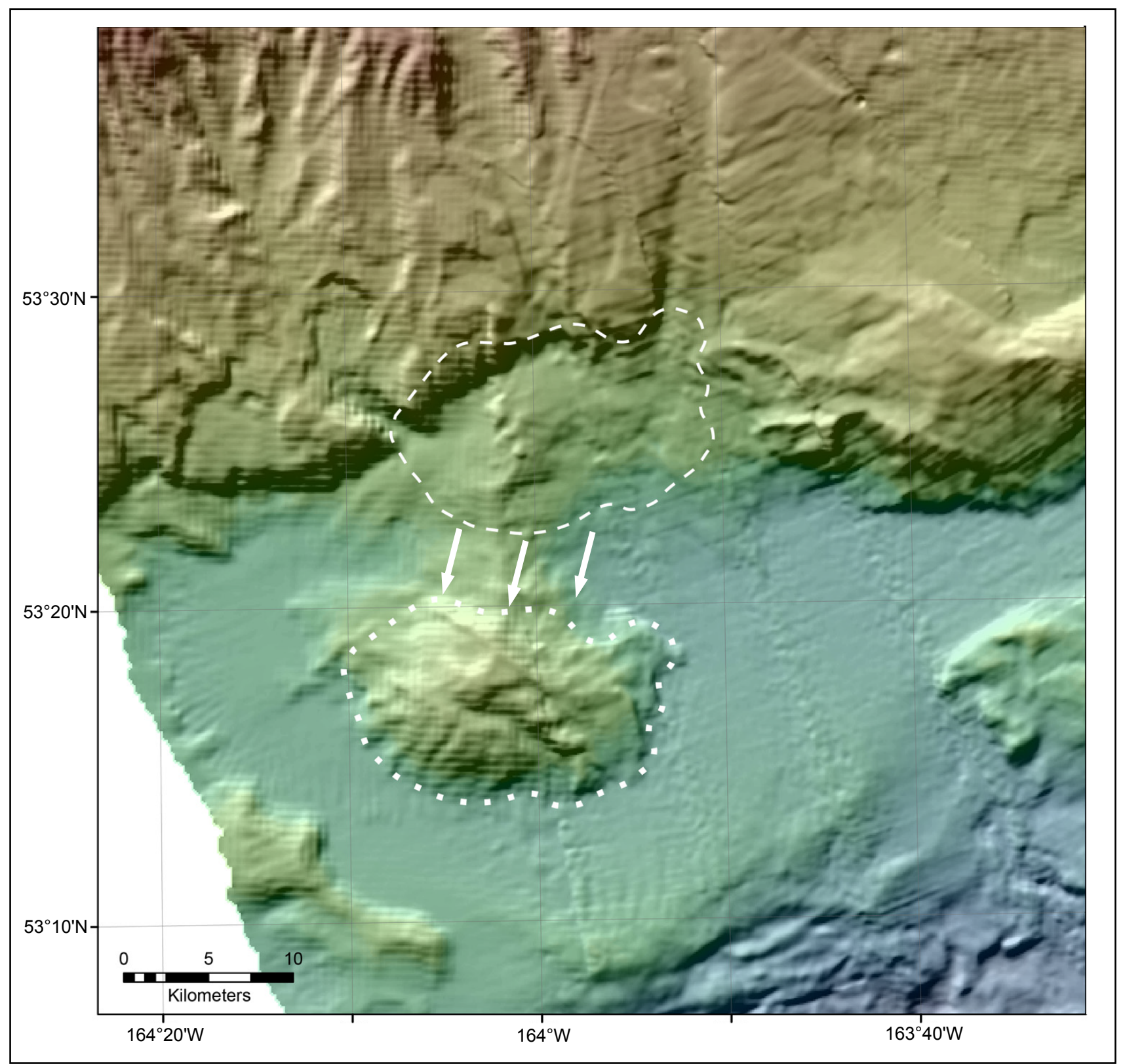

Figure 5. Bathymetry map of Lone Knoll (from von Huene and others, 2014). The inferred Lone Knoll landslide deposit indicated by dotted white line; inferred original location of the slide mass on the continental slope indicated by dashed white line.

\section{METHODOLOGY AND DATA}

\section{GRID DEVELOPMENT AND DATA SOURCES}

To compute a detailed map of potential tsunami inundation triggered by local and distant earthquakes we employ a series of nested computational grids. A nested grid allows for higher resolution in areas where it is needed without expending computer resources in areas where it is not. The bathymetric and topographic relief in each nested grid is based on digital elevation models (DEMs) developed at the National Centers for Environmental Information (NCEI) of the National Oceanic \& Atmospheric Administration (NOAA) in Boulder, Colorado. The extent of each grid used for the King Cove and Cold Bay mapping project is shown in figure 6 and listed in table 1. The coarsest grid, with 2-arc-minute (approximately 1.85 $\mathrm{x}$ $3.7 \mathrm{~km}$ [1.15 x $2.3 \mathrm{mi}]$ ) resolution, spans the central and northern Pacific Ocean (fig. 6A). The highest-resolution grid for King Cove covers the community of King Cove, the King Cove Lagoon and Harbor, and a part of Deer Passage, and the highest-resolution grid for Cold Bay covers the village of Cold Bay and a part of Cold Bay (fig. 6B). 


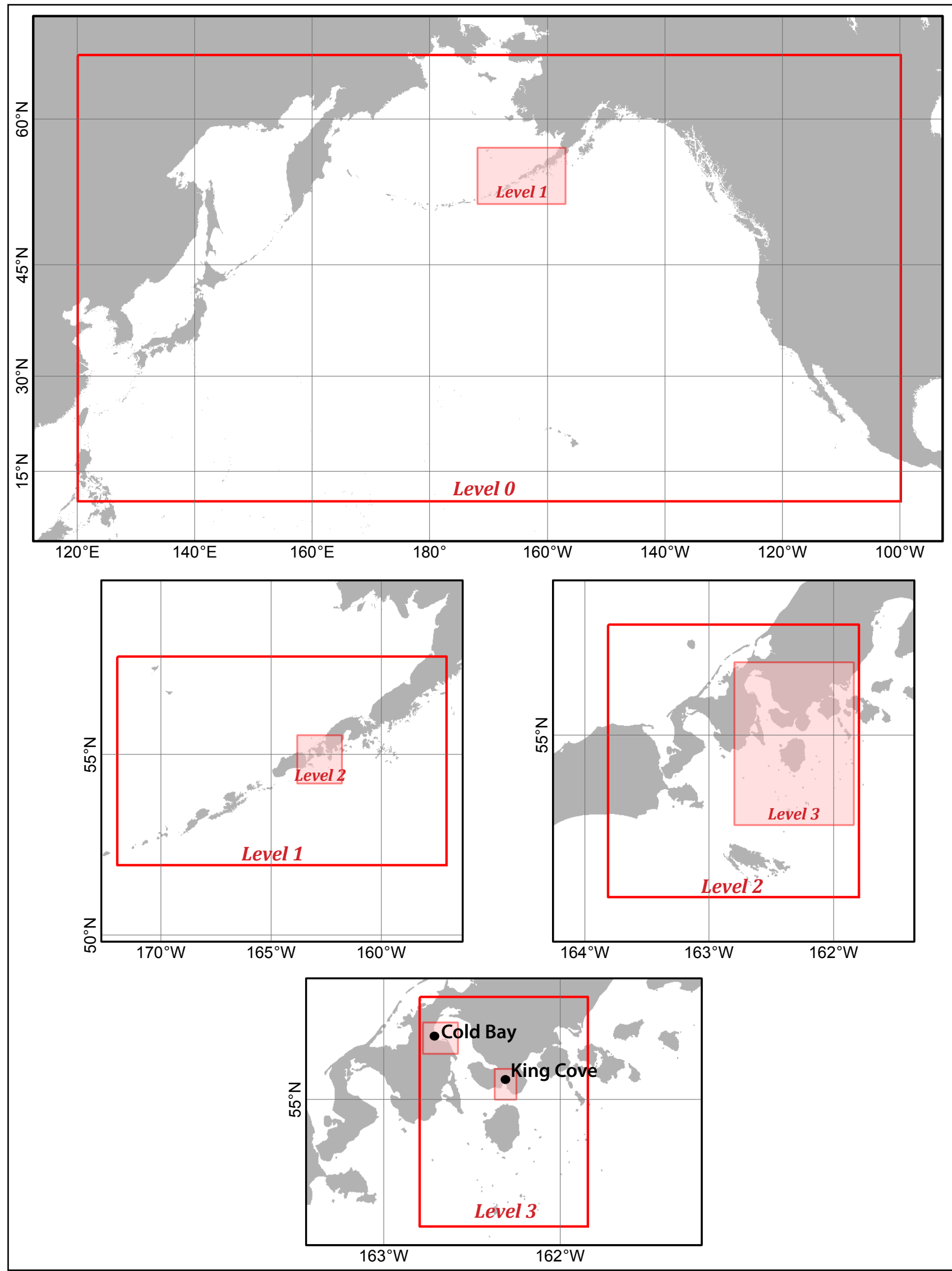

Figure 6. (A) Nesting of the bathymetry/topography grids for numerical modeling of tsunami propagation and runup. The coarsest grid, Level 0 , covers the central and northern Pacific Ocean. The location of each embedded grid is marked by a semi-transparent red rectangle. Refer to table 1 for grid parameters. 


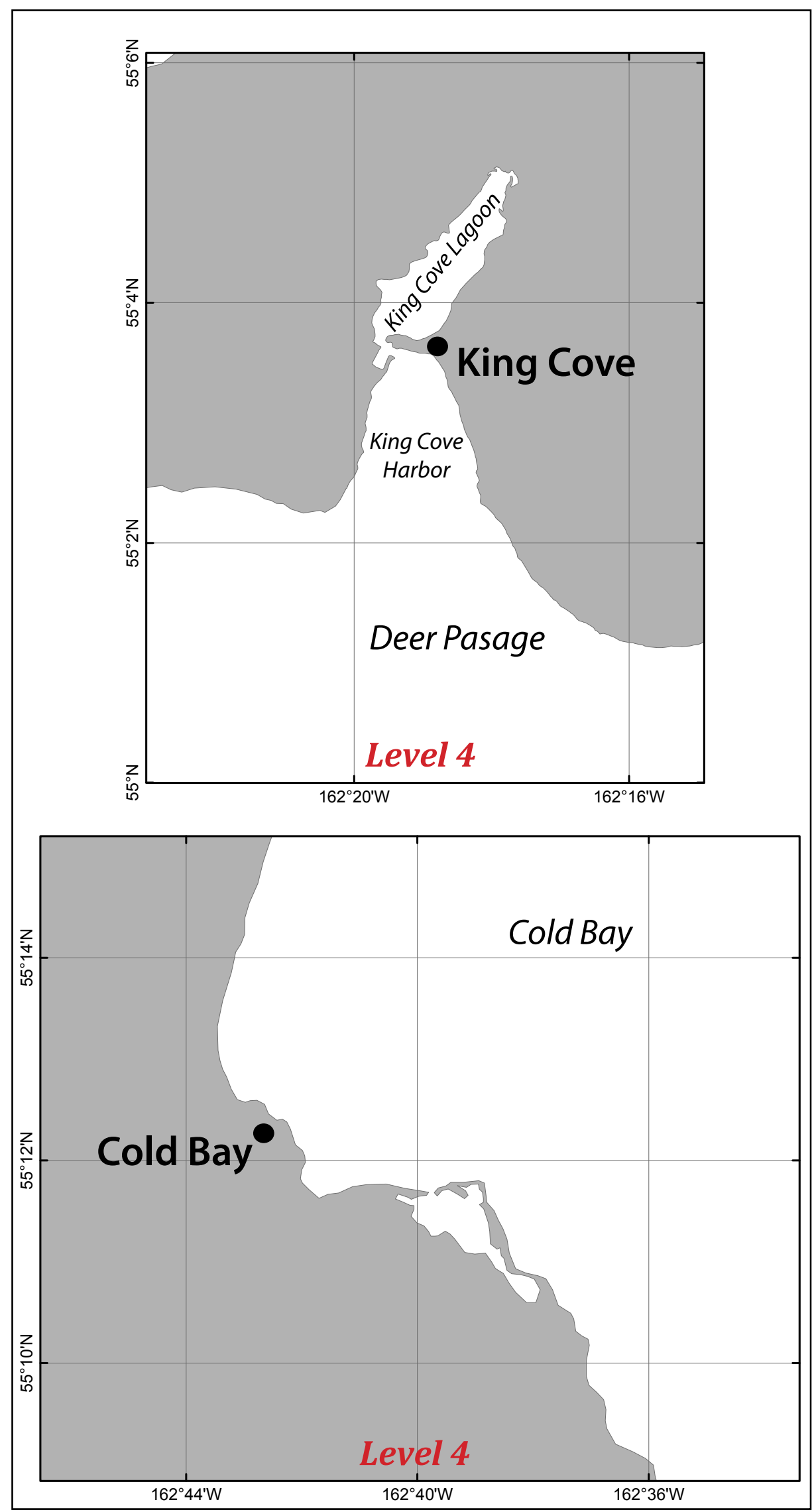

Figure 6 (cont). (B) Level 4 high-resolution bathymetry/topography grids for King Cove and Cold Bay. Refer to table 1 for grid parameters. 
Table 1. Nested grids used to compute propagation of tsunami waves generated in the Pacific Ocean to the communities of King Cove and Cold Bay. The high-resolution grids are used to compute the inundation. Note that the grid resolution in meters is not uniform and is used to illustrate grid fineness in the King Cove region. The first dimension is the longitudinal grid resolution, while the second is the latitudinal resolution.

\begin{tabular}{|l|c|c|c|l|}
\hline \multirow{2}{*}{ Grid name } & \multicolumn{2}{|c|}{ Resolution } & \multirow{2}{*}{$\begin{array}{c}\text { West-East } \\
\text { boundaries }\end{array}$} & $\begin{array}{l}\text { South-North } \\
\text { boundaries }\end{array}$ \\
\cline { 2 - 4 } & arc-seconds & $\begin{array}{c}\text { meters } \\
\text { (near King Cove) }\end{array}$ & $\begin{array}{l}120^{\circ} 00^{\prime} \mathrm{E}- \\
100^{\circ} 00^{\prime} \mathrm{W}\end{array}$ & $\begin{array}{l}10^{\circ} 00^{\prime} \mathrm{N}- \\
65^{\circ} 00^{\prime} \mathrm{N}\end{array}$ \\
\hline Level 0, Northern Pacific & $120 \times 120$ & $\approx 1,850 \times 3,700$ & $\begin{array}{l}171^{\circ} 58^{\prime} \mathrm{W}- \\
157^{\circ} 02^{\prime} \mathrm{W}\end{array}$ & $\begin{array}{l}52^{\circ} 00^{\prime} \mathrm{N}- \\
57^{\circ} 28^{\prime} \mathrm{N}\end{array}$ \\
\hline Level 1, Eastern Aleutians & $24 \times 24$ & $\approx 430 \times 740$ & $\begin{array}{l}161^{\circ} 47^{\prime} 44^{\prime \prime} \mathrm{W}- \\
163^{\circ} 48^{\prime} 42^{\prime \prime} \mathrm{W}\end{array}$ & $\begin{array}{l}54^{\circ} 14^{\prime} 35^{\prime \prime} \mathrm{N}- \\
55^{\circ} 30^{\prime} 14^{\prime \prime} \mathrm{N}\end{array}$ \\
\hline $\begin{array}{l}\text { Level 2, Coarse resolution western } \\
\text { Alaska Peninsula }\end{array}$ & $8 \times 8$ & $\approx 150 \times 250$ & $\begin{array}{l}161^{\circ} 50^{\prime} 24^{\prime \prime} \mathrm{W}- \\
162^{\circ} 47^{\prime} 53^{\prime \prime} \mathrm{W}\end{array}$ & $\begin{array}{l}54^{\circ} 34^{\prime} 54^{\prime \prime} \mathrm{N}- \\
55^{\circ} 19^{\prime} 59^{\prime \prime} \mathrm{N}\end{array}$ \\
\hline $\begin{array}{l}\text { Level 3, Fine resolution western } \\
\text { Alaska Peninsula }\end{array}$ & $8 / 3 \times 8 / 3$ & $\approx 48 \times 82$ & $\begin{array}{l}162^{\circ} 14^{\prime} 58^{\prime \prime} \mathrm{W}- \\
162^{\circ} 22^{\prime} 16^{\prime \prime} \mathrm{W}\end{array}$ & $\begin{array}{l}54^{\circ} 59^{\prime} 59^{\prime \prime} \mathrm{N}- \\
55^{\circ} 6^{\prime} 1^{\prime \prime} \mathrm{N}\end{array}$ \\
\hline $\begin{array}{l}\text { Level 4, High resolution King } \\
\text { Cove }\end{array}$ & $8 / 9 \times 8 / 15$ & $\approx 16 \times 16$ & $\begin{array}{l}162^{\circ} 34^{\prime} 47^{\prime \prime} \mathrm{W}- \\
162^{\circ} 46^{\prime} 50^{\prime \prime} \mathrm{W}\end{array}$ & $\begin{array}{l}55^{\circ} 8^{\prime} 58^{\prime \prime} \mathrm{N}- \\
55^{\circ} 15^{\prime} 3^{\prime \prime} \mathrm{N}\end{array}$ \\
\hline Level 4, High resolution Cold Bay & $8 / 9 \times 8 / 15$ & $\approx 16 \times 16$ \\
\hline
\end{tabular}

The spatial resolution of the high-resolution grid cells, with dimensions of about $16 \times 16 \mathrm{~m}(53 \times 53 \mathrm{ft})$ satisfies NOAA minimum recommended requirements for computation of tsunami inundation (National Tsunami Hazard Mapping Program [NTHMP], 2010). We use three intermediate grids between the coarsest- and highest-resolution grids (table 1). The bathymetric data for the 2-arc-minute-resolution grid is extracted from the ETOPO2 dataset (NCEI/NOAA). To develop 8/3-, 8-, and 24-arc-second-resolution grids, we obtained shoreline, bathymetric, and topographic digital datasets from the following U.S. federal and academic agencies: NOAA's National Ocean Service (NOS), Office of Coast Survey, and National Geophysical Data Center (NCEI); and the U.S. Army Corps of Engineers (USACE). All data were converted to World Geodetic System 1984 (WGS 84) horizontal datum and Mean Higher High Water (MHHW) vertical tidal datum. The data sources and methodology used to develop high-resolution 8/3-, 8-, and 24-arc-second DEMs are described in detail by Carignan and others (2013) and Lim and others (2011).

Accuracy of the high-resolution DEM is determined by the DCRA (Alaska Division of Community and Regional Affairs) elevation dataset, which contains survey data with the original Geoid 99 vertical datum of unknown accuracy. Because conversion of the DCRA datum to the MHHW tidal datum might introduce some vertical errors, prediction of the potential tsunami inundation using those data can be invalid. Hence, this topographic dataset was augmented with realtime kinematic (RTK) GPS survey data along near-shore areas in King Cove and Cold Bay; surveys in these communities were conducted August 9-14, 2012. Locations of the GPS measurements in King Cove and Cold Bay are shown in figures $7 \mathrm{~A}$ and 7B, respectively; the comparison of the GPS-estimated and NOAA-observed tide dynamics is shown in figures 8A and $8 \mathrm{~B}$. A detailed description of the survey procedure and the process of fitting the GPS results to the tidal variations is provided in Nicolsky and others (2014).

We check the accuracy of our conversion of the GPS data to the MHHW level by estimating the height of the tidal station disk '9881C 2005' in King Cove. According to the NOAA website (http://tidesandcurrents.noaa.gov) the disk is $4.266 \mathrm{~m}$ (13.996 ft) above Mean Lower Low Water (MLLW), or $2.184 \mathrm{~m}(7.165 \mathrm{ft})$ above MHHW. After measuring the height of this disk during the GPS survey and converting to the MHHW datum, we estimate that the disk is $2.206 \mathrm{~m}$ ( $7.238 \mathrm{ft}$ ) above MHHW. The difference of less than $0.1 \mathrm{~m}(0.33 \mathrm{ft})$ between the NOAA stamping and our estimates demonstrates that the conversion of the GPS measurements to the MHHW level provides sub-meter accuracy. Unfortunately, we were not able to locate a suitable tidal disk in Cold Bay to check the accuracy of data conversion at this location. However, exactly the same technique was used to convert the GPS data for Cold Bay as was used for King Cove. While the difference between any two GPS measurements has a horizontal error of 3-5 cm (1.2-2.0 in), a horizontal error for any point is defined by the error of the base station. We allowed the base station to establish its position by averaging the received coordinates for 5-15 minutes, but we did not reference our GPS measurements to any horizontal benchmark. Therefore, for the sake of safety, we assume that a horizontal error in the base station location is about $3-5 \mathrm{~m}(10-16 \mathrm{ft})$, which is comparable with the handheld GPS device and the spatial resolution of the tsunami DEMs $(15 \times 15 \mathrm{~m}[49 \times 49 \mathrm{ft}])$. The converted GPS survey has been provided to the NCEI, where the high-resolution DEMs of King Cove, Cold Bay, and adjacent areas have been developed. 


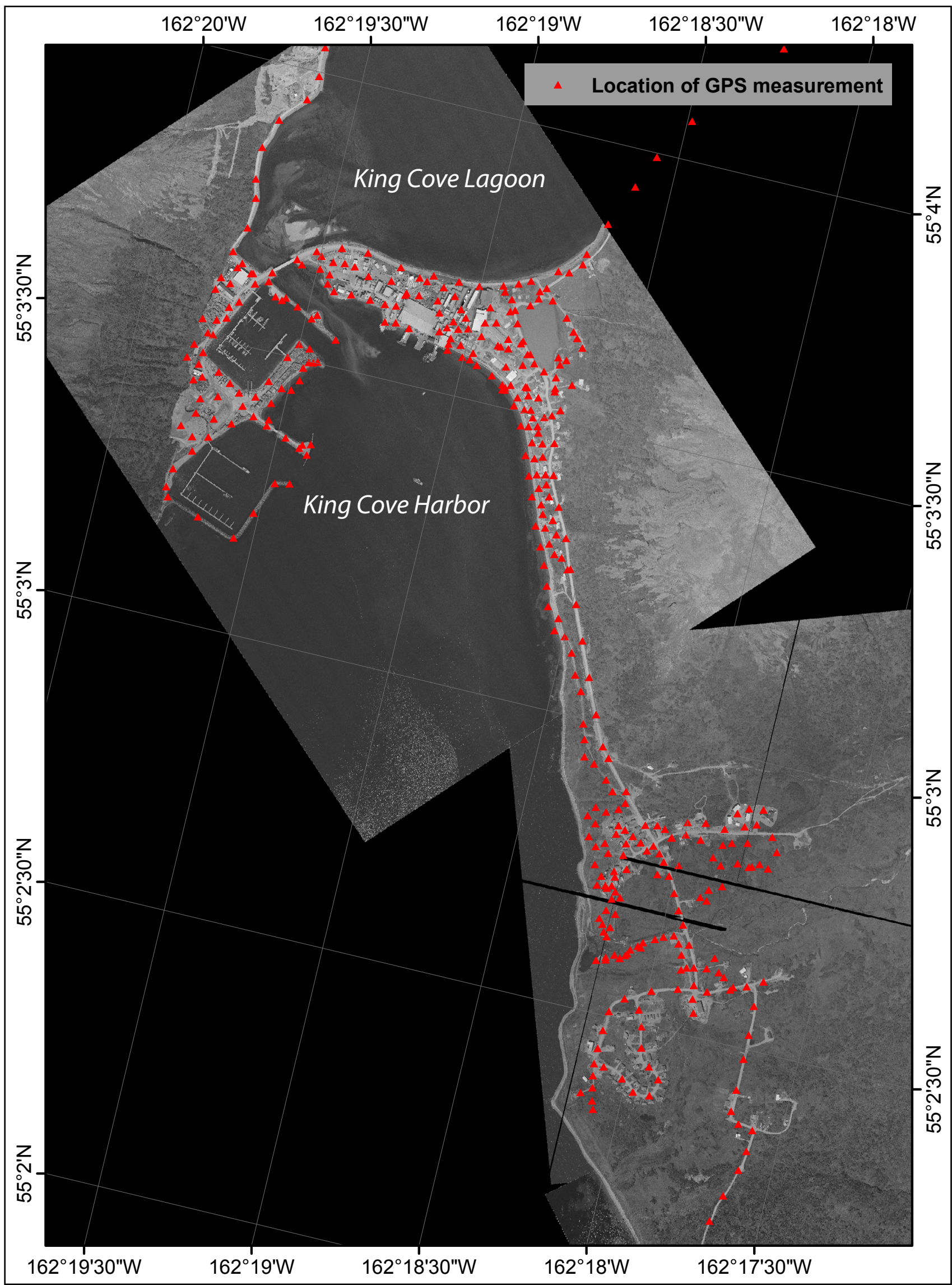

Figure 7. (A) Locations of RTK (real-time kinematic) GPS measurements at King Cove. 


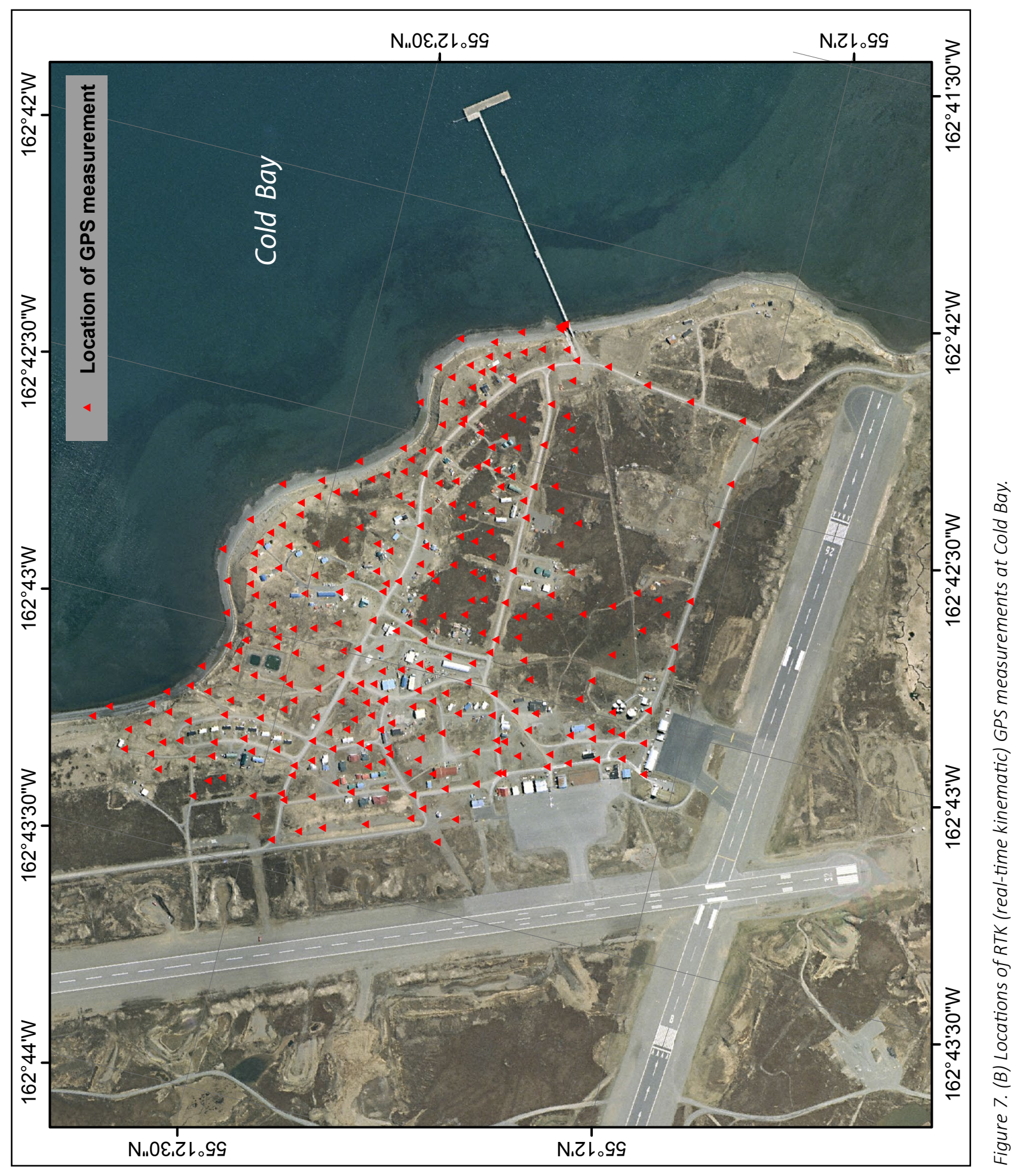




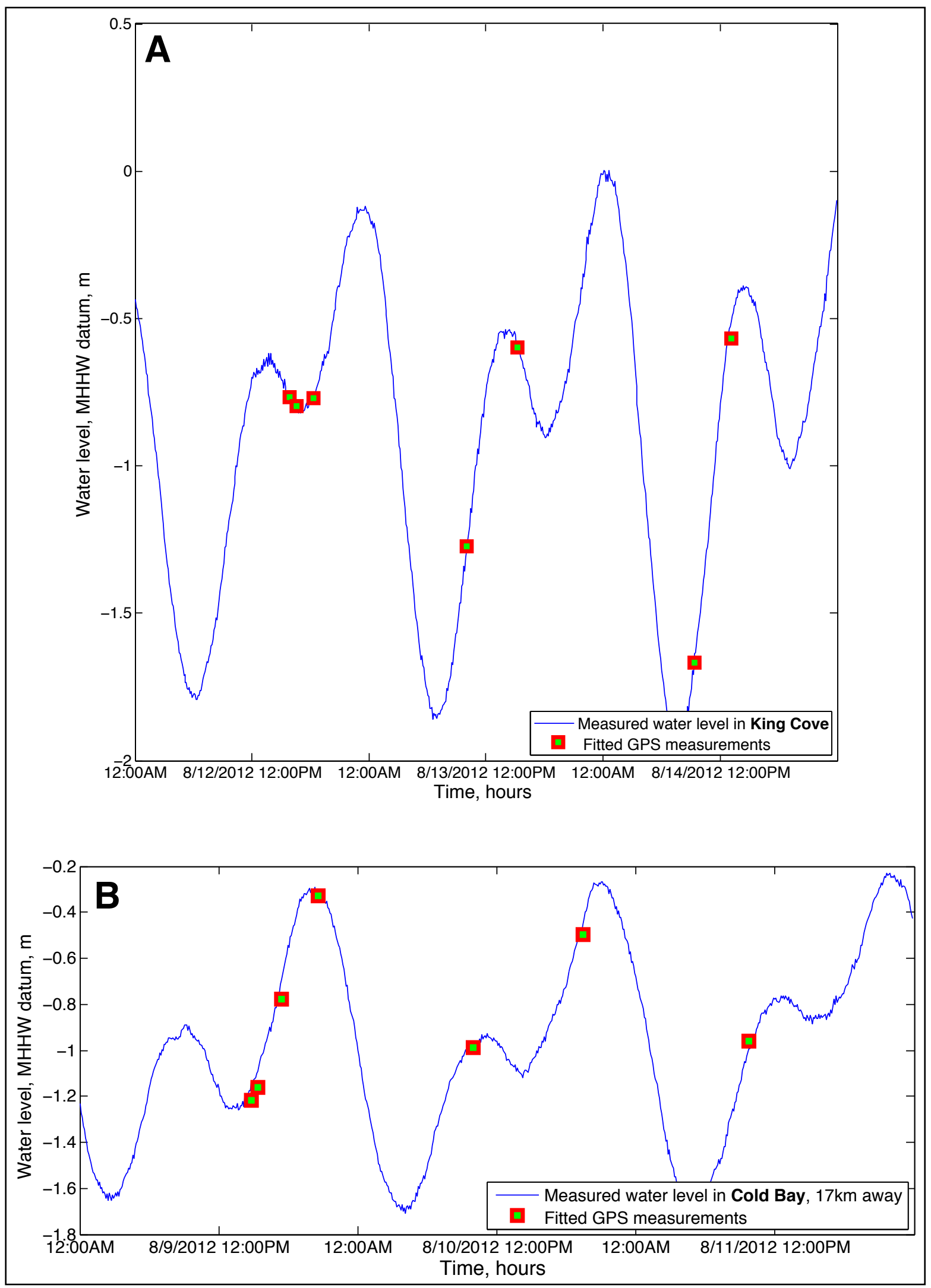

Figure 8. Predicted water-level dynamics and the fitted GPS measurements of the water level in the MHHW tidal datum for King Cove (A) and Cold Bay (B). 


\section{NUMERICAL MODEL OF TSUNAMI PROPAGATION AND RUNUP}

The numerical model currently used by the Alaska Earthquake Center (AEC; http://earthquake.alaska.edu/) for tsunami inundation mapping has been validated through a set of analytical benchmarks and tested against laboratory and field data (Nicolsky and others, 2011b; Nicolsky, 2012). The model solves the nonlinear shallow-water equations using a finitedifference method on a staggered grid. For any coarse-fine pair of computational grids we apply a time-explicit numerical scheme as follows. First we compute the water flux in a coarse-resolution grid. These calculated flux values are used to define the water flux on a boundary of the fine-resolution grid. Next the water level and then the water flux are calculated over the fine-resolution grid. Finally the water level computed in the fine-resolution grid is used to define the water level in the area of the coarse-resolution grid that coincides with the fine grid. Subsequently we compute the water elevation for all other points in the coarse grid and proceed to the next time step. More details about the numerical scheme, grid nesting, and time stepping can be found in Goto and others (1997) and in Nicolsky and others (2011b). The application of the model to tsunami inundation mapping of Alaska coastal communities, including its assumptions and limitations, is described in a number of previous tsunami reports, for example, Suleimani and others $(2010,2013,2015)$ and Nicolsky and others (2011a, 2013, 2014, 2015). In this study we conduct all model runs using bathymetric data that correspond to the MHHW tide level in King Cove and Cold Bay.

\section{MODELING OF THE MARCH 11, 2011, TOHOKU TSUNAMI}

To assess tsunami hazards in King Cove and Cold Bay, we consider both local and distant potential tsunami sources. Among many reasons for model verification listed in Synolakis and others (2007), the one that is most significant for distant tsunami events is checking the consistency of the DEM nesting. To test the accuracy of the grid nesting around King Cove and Cold Bay, we complete a model verification study of the Tohoku tsunami of March 11,2011. Using a method similar to Nicolsky and others (2015), we compare modeling results with observed wave dynamics at the King Cove tidal station (point 28 in fig. A1). We employ Shao and others' (2011) finite fault inversions model phase III, which predicts the vertical coseismic deformation shown in figure 9. The Tohoku tsunami produced a $0.54-\mathrm{m}$-high (1.8-ft-high) maximum wave in King Cove (NCEI/WDS Global Historical Tsunami Database), whereas the simulation predicts a 0.8-m-high (2.6-ft-high) wave (fig. 10). Similarly to Tang and others (2012), we observe a time delay between the computed and observed waves. The computed wave arrives at King Cove $\delta \mathrm{T}=9$ minutes sooner than the observed one. The comparison between the computed and observed wave shows good correspondence between the amplitude and the phase of the first arrival. The later waves in the simulated signal are larger, which could be due to low resolution of the coastline in the Level 1-3 grids (table 1 and fig. 6). Overall, the model provides a good approximation to the recorded tsunami amplitudes in King Cove harbor, which indicates that the proposed coseismic deformation model adequately describes the coseismic slip distribution, and the DEM nesting is selected appropriately.

The far-field Tohoku tsunami did not result in a significant wave at King Cove due to its distance from the tsunami source and directivity patterns of the energy propagation. However, other distant events might produce greater wave heights in King Cove and Cold Bay and should not be dismissed without a proper evaluation.

\section{TSUNAMI SOURCES}

A critical component of the Alaska tsunami-inundation mapping project is accurate identification and characterization of potential tsunami sources. As demonstrated by the 2011 Tohoku tsunami, correct estimation of the maximum size event for a given segment of the subduction zone is particularly important. Based on seafloor GPS and seafloor pressure gage observations, during the 2011 Tohoku earthquake, an unexpectedly large amount of slip occurred approximately updip of the epicenter of the main shock, generating a much larger tsunami than anticipated (Fujii and others, 2011). In our project, we employ the deterministic method to develop potential tsunami sources, which is distinctly different from the probabilistic tsunami hazard analysis used in projects with different objectives, such as land-use planning or insurance estimates (Geist and Parsons, 2006). The Alaska tsunami inundation maps are produced on the basis of a maximum credible tsunami scenario for a given segment of the coastline (for example, Nicolsky and others, 2011a, 2013, 2014; Suleimani and others, 2010, 2013, 2015). To determine credible sources, we study the region-specific subduction processes and use up-to-date geophysical data and research models that define the magnitude range of possible future tsunami events. Nicolsky and others (2015) also outlined a strategy for generating worst-case credible tsunami scenarios for locations that have a short or nonexistent paleoseismic/paleotsunami record, and in some cases lack modern seismic and GPS data. Below we briefly review some aspects of the region's plate tectonics and locations of locked and creeping zones along the Aleutian megathrust in the study area. These factors are taken into account when we define spatial extents of hypothetical tsunamigenic ruptures.

\section{Seismicity}

The Alaska-Aleutian arc is one of the most seismically active regions in the world and has experienced some of the largest events in recorded history. Almost the entire arc ruptured in a series of events $M_{W}$ 7.4-9.2 starting with the $M_{W} 8.3$ earthquake near Kodiak Island in 1938 and culminating with the $\mathrm{M}_{\mathrm{W}} 8.7$ Rat Island earthquake in 1965. However, there has not been a great earthquake rupture along the megathrust underneath the Shumagin Islands archipelago in historic time. Figure 11 shows the area of the Shumagin gap with background seismicity and the focal mechanisms of the three 


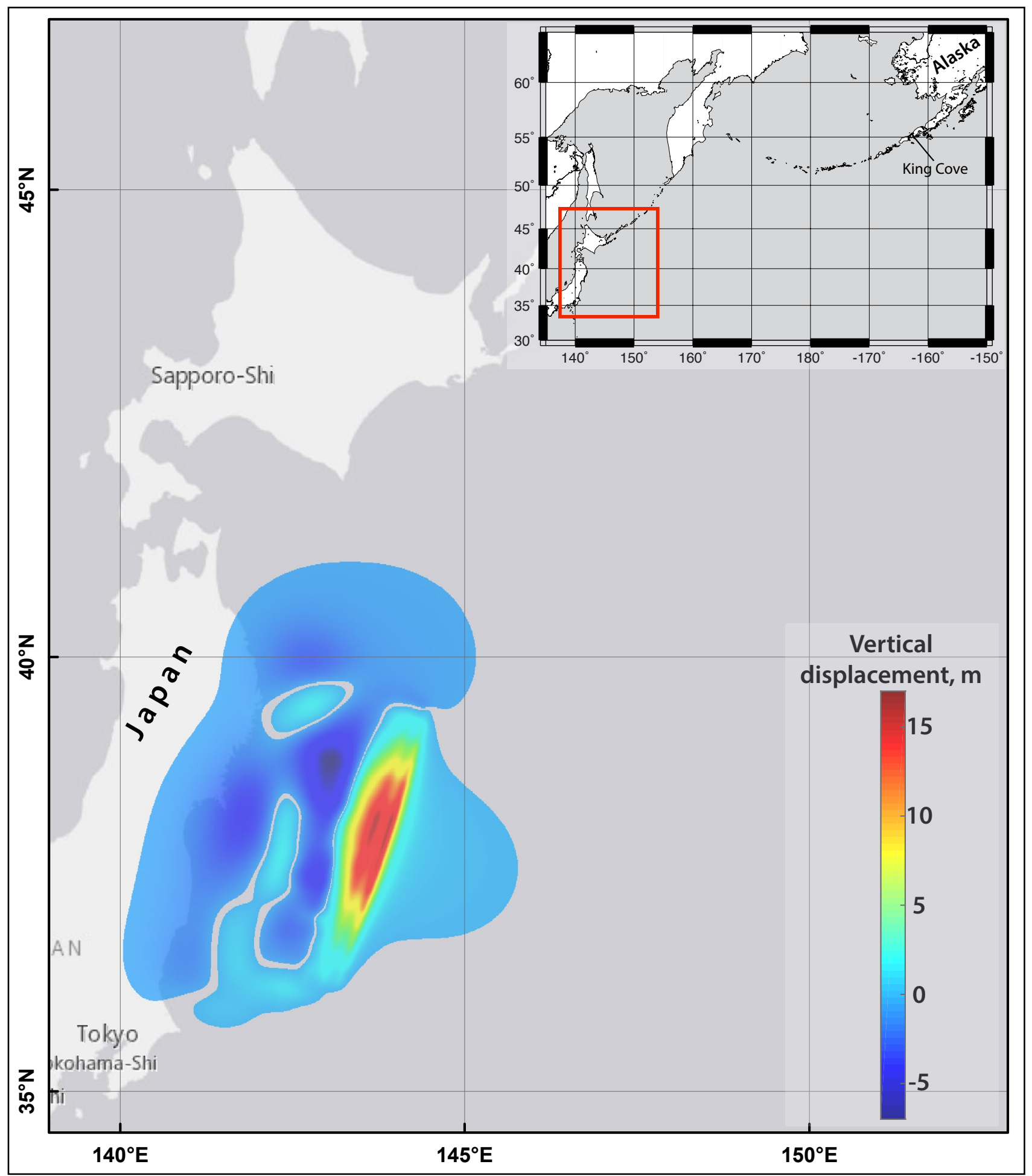

Figure 9. Vertical deformations of the ocean floor and adjacent coastal region corresponding to the March 11, 2011, Tohoku earthquake, based on a finite fault model by Shao (http://www.tectonics.caltech.edu/). Warm colors indicate uplift; blue indicates subsidence. Inset map shows the location of the Tohoku earthquake source with respect to the King Cove tide gauge. 


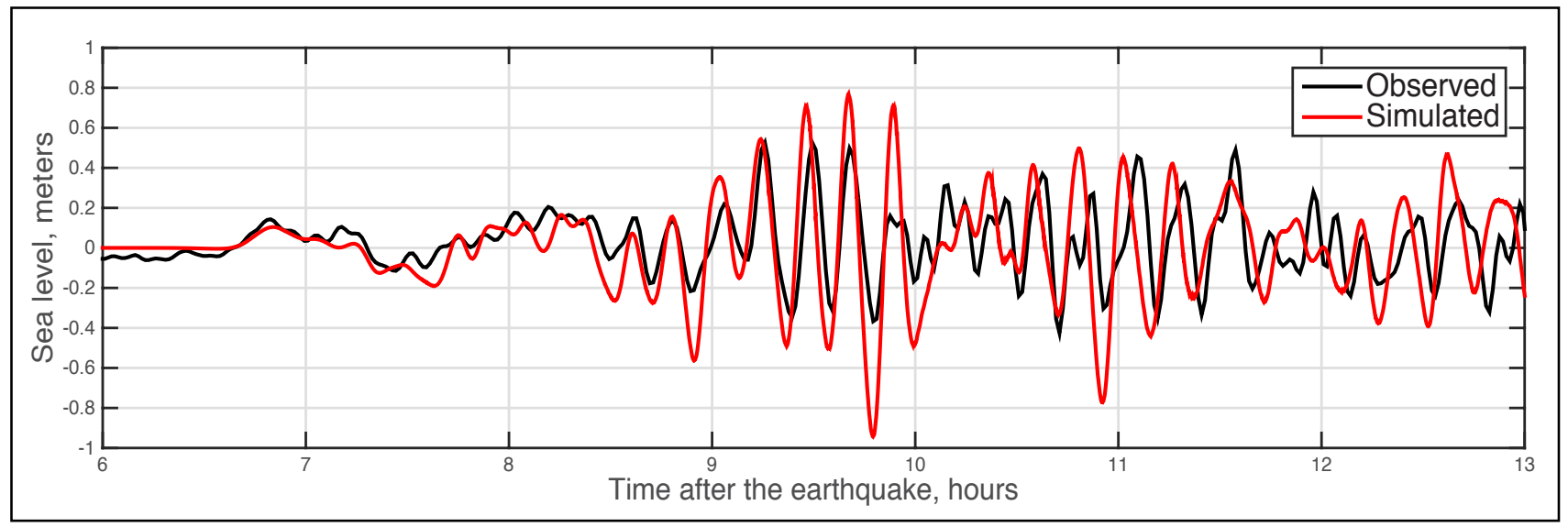

Figure 10. Observed and simulated water-level dynamics at the King Cove tide station during the March 11, 2011, Tohoku tsunami.

most recent significant earthquakes in the region. The largest of them, $M_{W} 7.1$, occurred in the study area in 1948, before deployment of the World Wide Standardized Seismograph Network. Detailed analyses of this event are contained in Davies and others (1981), who suggested that the seismic gap could be broken by a series of large earthquakes with $\mathrm{M}_{\mathrm{W}}$ ranging from 7.2 to 7.8. Tanioka and others (1994) studied the $\mathrm{M}_{\mathrm{W}} 6.91993$ earthquake and calculated synthesized tsunami waves. They concluded that their estimation of the seismic moment and rupture area are consistent with the observed absence of a tsunami signal. Nishenko (1991) analyzed the seismic potential of the Shumagin gap region and pointed out that while the gap may not be capable of producing a great earthquake, it is capable of independently producing mid-7 magnitude events, and also could be part of a bigger rupture. An additional analysis of other significant thrust earthquakes along the Alaska Peninsula can be found in Tichelaar and Ruff (1993).

\section{Geodetic studies}

Fournier and Freymueller (2007) used geodetic observations of active deformation in the Shumagin region to assess strain accumulation related to the earthquake cycle. They modeled GPS velocities from the Alaska Peninsula to find the extent of locking on the subduction interface. The plate interface between the Pacific and North America plates along the Alaska Peninsula and Shumagin Islands was divided into several rectangular planar segments (fig. 11 shows three of these segments). They estimated the amount of slip occurring on each segment; results are reported in terms of a coupling ratio for each plane. A coupling ratio of zero results when the plate interface is constantly slipping at the long-term relative plate velocity; this indicates that no strain is building up to contribute to future great earthquakes. A coupling ratio of 100 percent indicates no slip, that the plate interface is completely locked over that segment; regions of high coupling ratio are termed locked zones. A coupling ratio between these high and low values may mean that only a portion of the plate interface is locked, or it could mean that the entire interface creeps at a rate somewhat slower than the rate of plate motion. The coupling ratio for each plane is marked by percentage values shown in red in figure 11. The modeling results of Fournier and Freymueller (2007) reveal that the plate interface near the Shumagin Islands (plane 2) is dominated by creeping (coupling ratio only 30 percent), but indicate that shear stress is accumulating on part of the interface. Note that most of the significant earthquakes that have been recorded by the AEC in this area are near the Shumagin Islands at the downdip end of plane 2, around $37 \mathrm{~km}(23 \mathrm{mi})$ in depth. The estimated downdip extent of seismic coupling inferred from these earthquakes quantitatively agrees with the analysis of upper plate seismicity (Tichelaar and Ruff, 1993). Tichelaar and Ruff (1993) predict the downdip limit of the locked region to be at $37-41 \mathrm{~km}(23-26 \mathrm{mi})$ depth.

Determining the location of the updip limit of the locked zone is hindered by the lack of geodetic data close to the Aleutian trench, and is essentially unconstrained by the land-based geodetic data. Seafloor GPS/acoustic measurements would be required to constrain the existence or absence of high coupling at shallow depth. Fournier and Freymueller (2007) assumed that the locked zone extended to the trench. Plane 1, which is offshore of King Cove and Cold Bay, is estimated to be almost entirely creeping (coupling ratio of 2 percent), because zero deformation is observed between geodetic sites along that segment. However, because of the poor model resolution near the trench there could still be a shallow locked zone. Fournier and Freymueller (2007) tested models to evaluate the area of the largest possible locked zone that did not violate the data. Assuming the locked zone started at the trench and had a coupling ratio of 100 percent, the shaded area of plane 1 in figure 11 shows the widest possible fully locked interface, at the 95 percent confidence level. Recent studies comparing the Alaska and Tohoku margins (Ryan and others, 2012; Kirby and others, 2013) propose that a hypothetical rupture might propagate to shallow depths, similar to the $\mathrm{M}_{\mathrm{W}}$ 9.0 Tohoku earthquake, based on several similarities between the two margins. Therefore, in our scenarios, we allow earthquakes that rupture the potential shallow locked zone where tectonic plates near the trench may be coupled. 


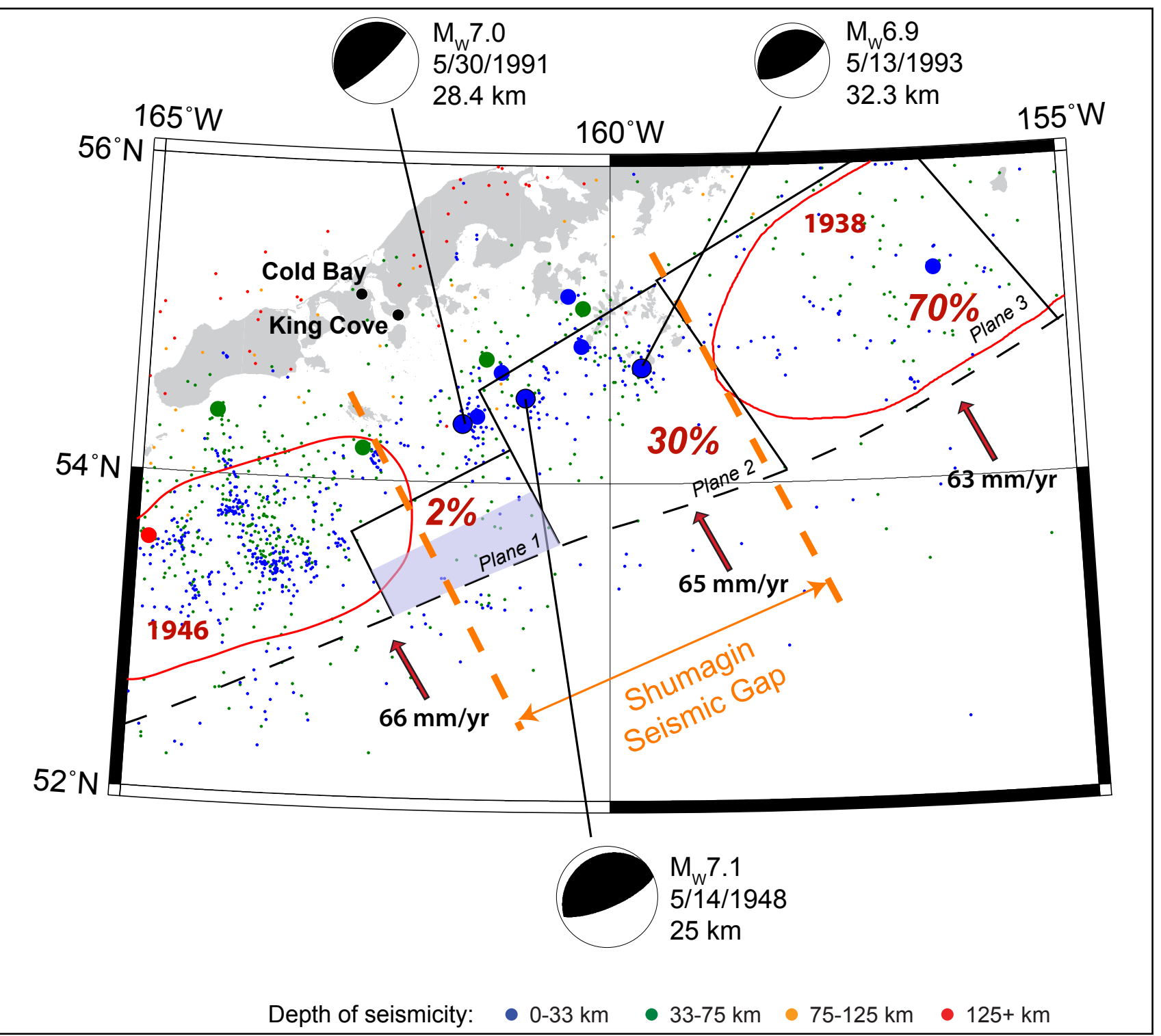

Figure 11. Earthquakes near western Alaska Peninsula (data from Alaska Earthquake Center catalog). Small and large dots correspond to earthquakes with magnitudes less than 6 and 6 or greater, respectively. Source mechanisms are shown for the three largest earthquakes in the area of the Shumagin Islands. The trench is marked by a dashed black line. Red arrows indicate the rate of convergence of the Pacific and North American plates. Black rectangles mark locations of fault planes for which the percent of unit coupling is estimated by Fournier and Freymueller (2007). Location of the Shumagin seismic gap is bounded by dashed orange lines. The shaded area in Plane 1 indicates the widest possible fully locked interface, according to Fournier and Freymueller (2007).

\section{Paleoseismological constraints}

Witter and others (2014) analyzed data collected during a field paleoseismic investigation of Simeonof Island, the easternmost island of the Shumagin archipelago (fig. 1). The data indicate that there have been no sudden coseismic vertical

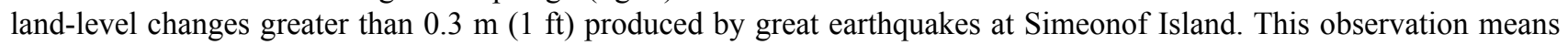
that if great earthquakes have ruptured that segment of the megathrust, Simeonof Island must lie very close to the hinge line - the line of zero vertical displacement that separates the region of uplift near the updip end of the rupture from the region of subsidence near the downdip end of the rupture. However, for the segment to the west of Shumagin Islands, no paleoseismic constraints are available and a wider range of slip distributions is geologically plausible. 


\section{Methodology}

Our goal is to determine geologically plausible worst-case scenarios that will result in maximum tsunami inundation in King Cove and Cold Bay. To do that, we consider all possible scenarios that do not contradict existing data.

To simulate potential earthquakes on the Aleutian megathrust we employ a model of the Alaska-Aleutian plate interface between the subducting and overriding plates. The plate interface model by Hayes and others (2012) is discretized into a number of rectangles ranging from 3 to $6 \mathrm{~km}(1.9-3.7 \mathrm{mi})$ in the along-strike direction of the plate interface. The upper and lower edges of each rectangle coincide with depth contours of the plate interface that are spaced at $1 \mathrm{~km}(0.6 \mathrm{mi})$ (fig. 12). The rectangles, called subfaults, are later used to compute coseismic ground deformation (Okada, 1985). Using this discretization of the plate interface, we can model potential earthquake scenarios by first prescribing a general pattern of slip distribution in the proposed rupture, and then computing the slip at the center of each subfault using seismic moment as a constraint.

Next we construct local hypothetical ruptures that could generate tsunami waves at King Cove and Cold Bay. In this study we focus on the Shumagin gap region and adjacent segments of the megathrust. Figure 13 shows the plate interface in the study area, divided into five regions in the along-strike direction, and into four depth intervals in the downdip direction, for a total of 20 interface segments. We use this mosaic to develop hypothetical ruptures that satisfy different geodetic and geologic constraints. Considerations for selecting or excluding certain segments are outlined below in the description of the scenarios. For each modeled slip distribution on the plate interface, we simulate the impact of the resulting tsunami in King Cove and Cold Bay. In addition to the near-field tsunami sources that are constructed based on the assessment of locked regions near the Shumagin Islands and geologic data, we include several tsunami sources that have been considered in previous inundation mapping reports, such as the rupture of the Cascadia subduction zone involving the Juan de Fuca plate from Vancouver Island in British Columbia to northern California, an outer-rise earthquake, and a Tohoku-type earthquake in the Shumagin Islands region.

\section{Hypothetical tsunami scenarios}

For the eastern part of the study area, represented by sections $\mathrm{D}$ and $\mathrm{E}$ in figure 13, the potential slip distributions are constrained by field data that indicate the absence of any sudden coseismic vertical land-level changes greater than $0.3 \mathrm{~m}$ $(1 \mathrm{ft})$ produced by great earthquakes at Simeonof Island (Witter and others, 2014), and suggest that the island must lie very close to the megathrust hingeline. Segments 17-20 are areas of the interface that are not locked at depths greater than about $30 \mathrm{~km}$ (18.6 mi) (Lisowski and others, 1988; Fletcher and others, 2001; Fournier and Freymueller, 2007). Segments 7-8 and 12-13 are areas that have no record of great earthquakes and is a freely slipping segment of the plate interface, based on the modeling of GPS velocities by Fournier and Freymueller (2007). Also, the green shading of segments 17-20 indicate that these areas of the interface at depths greater than about $30 \mathrm{~km}(18.6 \mathrm{mi})$ are not locked (Lisowski and others, 1988; Fletcher and others, 2001; Fournier and Freymueller, 2007). The green shading of segments 7-8 and 12-13 indicates the area that has no record of great earthquakes and is a freely slipping segment of the plate interface, based on modeling of GPS velocities (Fournier and Freymueller, 2007). These constraints are taken into account in development of selected scenarios.

Table 2 lists all hypothetical tsunami sources evaluated for King Cove and Cold Bay. The proposed slip distributions for selected scenarios are shown in figure 14; vertical coseismic deformations for all scenarios are shown in figure 15. The developed scenarios demonstrate the sensitivity of tsunami runup in King Cove and Cold Bay to variable slip distributions and are valuable in determining the tsunami hazard zone in these communities. Below we describe the scenarios, grouped by specific source characteristics.

The first group of tsunami scenarios includes six sources (scenarios 1-6) that reflect the presence of Shumagin gap as a freely slipping segment of the plate interface, and therefore do not have any slip placed in the green-shaded segments of the rupture mosaic in figure 13. For the remaining segments shaded in pink, we allow a maximum slip of $50 \mathrm{~m}$ (164 ft) in the shallow part (segments 1-5), and a maximum slip of 35-40 m (115-131 ft) in other segments. The average and maximum slip as well as the rupture areas for scenarios 1-6 are set according to the scaling relations of Papazachos and others (2005) and Moss and Travasarou (2006).

\section{Scenario $1 . \mathrm{M}_{\mathrm{W}} 9.1$ earthquake in the western Alaska Peninsula region: Two asperities and trench}

This event is a hypothetical $\mathrm{M}_{\mathrm{W}} 9.1$ earthquake rupturing the Aleutian megathrust. Zero slip is assigned to segments 7, 8, 12, 13, and 17-20. The source consists of a western and eastern asperity, separated by the Shumagin gap and connected only by slip in the shallow part of the rupture, close to the trench. The maximum slip of $50 \mathrm{~m}$ (164 ft) is at a depth of 5-15 km (3-9 mi). The proposed slip distribution is shown in figure 14A; vertical coseismic deformations for this scenario are shown in figure 15A.

Scenario 2. $\mathrm{M}_{\mathrm{W}} 9.1$ earthquake in the western Alaska Peninsula region: Two asperities, weakly connected

This event is a hypothetical $\mathrm{M}_{\mathrm{W}} 9.1$ earthquake rupturing the Aleutian megathrust. Zero slip is assigned to segments $7,8,12,13$, and 17-20. The source consists of a western and eastern asperity, separated by Shumagin gap and connected only by slip in the shallow part of the rupture, close to the trench. The difference between this scenario 


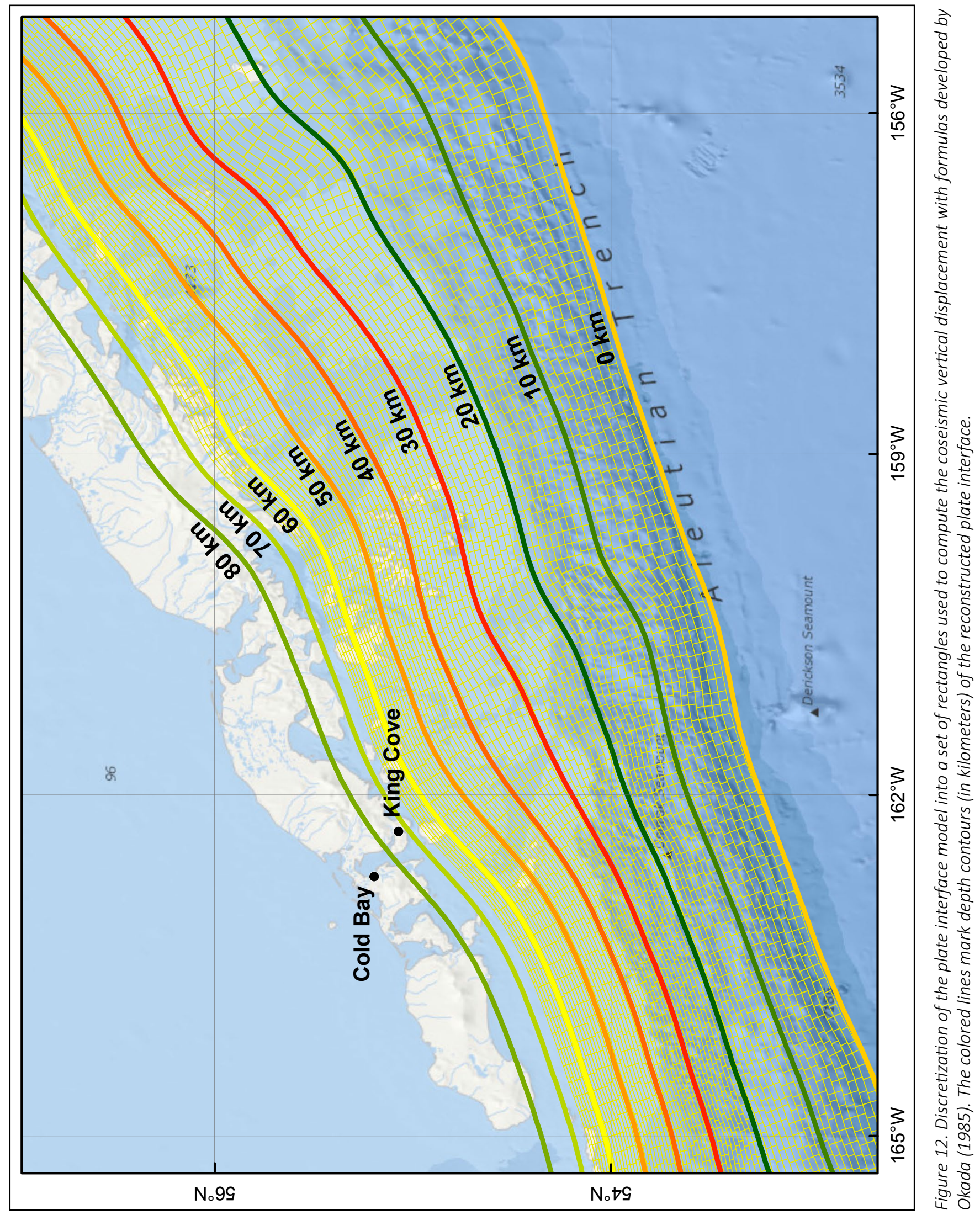


and scenario 1 is in the amount of slip placed in the area connecting the two asperities, which is much smaller in this scenario. The maximum slip of $50 \mathrm{~m}(164 \mathrm{ft})$ is at a depth of 5-15 km (3-9 mi). The proposed slip distribution is shown in figure 14B; vertical coseismic deformations for this scenario are shown in figure 15B.

\section{Scenario 3. $\mathrm{M}_{\mathrm{W}}$ 8.9earthquake in the western Alaska Peninsula region: Eastern asperity and trench}

This event is a hypothetical $\mathrm{M}_{\mathrm{W}} 8.9$ earthquake rupturing the Aleutian megathrust. Zero slip is assigned to segments 6-8, 11-13, and 16-20. The source consists of an eastern asperity and an area of higher slip at shallow depth close to the trench. The maximum slip of $50 \mathrm{~m}(164 \mathrm{ft})$ is at a depth of 5-15 km (3-9 mi). The proposed slip distribution is shown in figure 14C; vertical coseismic deformations for this scenario are shown in figure 15C.

\section{Scenario 4. $\mathrm{M}_{\mathrm{W}} 9.0$ earthquake in the western Alaska Peninsula region: Western asperity and trench}

This event is a hypothetical $\mathrm{M}_{\mathrm{W}} 9.0$ earthquake rupturing the Aleutian megathrust. Zero slip is assigned to segments $7-10,12-15$, and 17-20. The source consists of a western asperity and an area of higher slip at shallow depth close to the trench. The maximum slip of $50 \mathrm{~m}(164 \mathrm{ft})$ is at a depth of 5-15 km (3-9 mi). The proposed slip distribution is shown in figure 14D; vertical coseismic deformations for this scenario are shown in figure 15D.

To expand the range of possible tsunami events and include sources that are considered more realistic for the Shumagin gap segment of the megathrust (Wesson and others, 2007, 2008), we considered scenarios 5 and 6 with magnitudes $M_{W} 8.6$ and $\mathrm{M}_{\mathrm{W}}$ 8.3, respectively, which represent the eastern and western asperities of the earthquake source in scenario 2.

\section{Scenario 5. $\mathrm{M}_{\mathrm{W}} 8.6$ earthquake in the western Alaska Peninsula region: Eastern asperity only}

This event is a hypothetical $\mathrm{M}_{\mathrm{W}} 8.6$ earthquake rupturing the Aleutian megathrust. Zero slip is assigned to segments $1-3,6-8,11-13$ and 16-19. The source consists of an eastern asperity only. The maximum slip of $15 \mathrm{~m}$ (50 $\mathrm{ft})$ is at a depth of 5-15 km (3-9 mi). The proposed slip distribution is shown in figure 14E; vertical coseismic deformations for this scenario are shown in figure 15E.

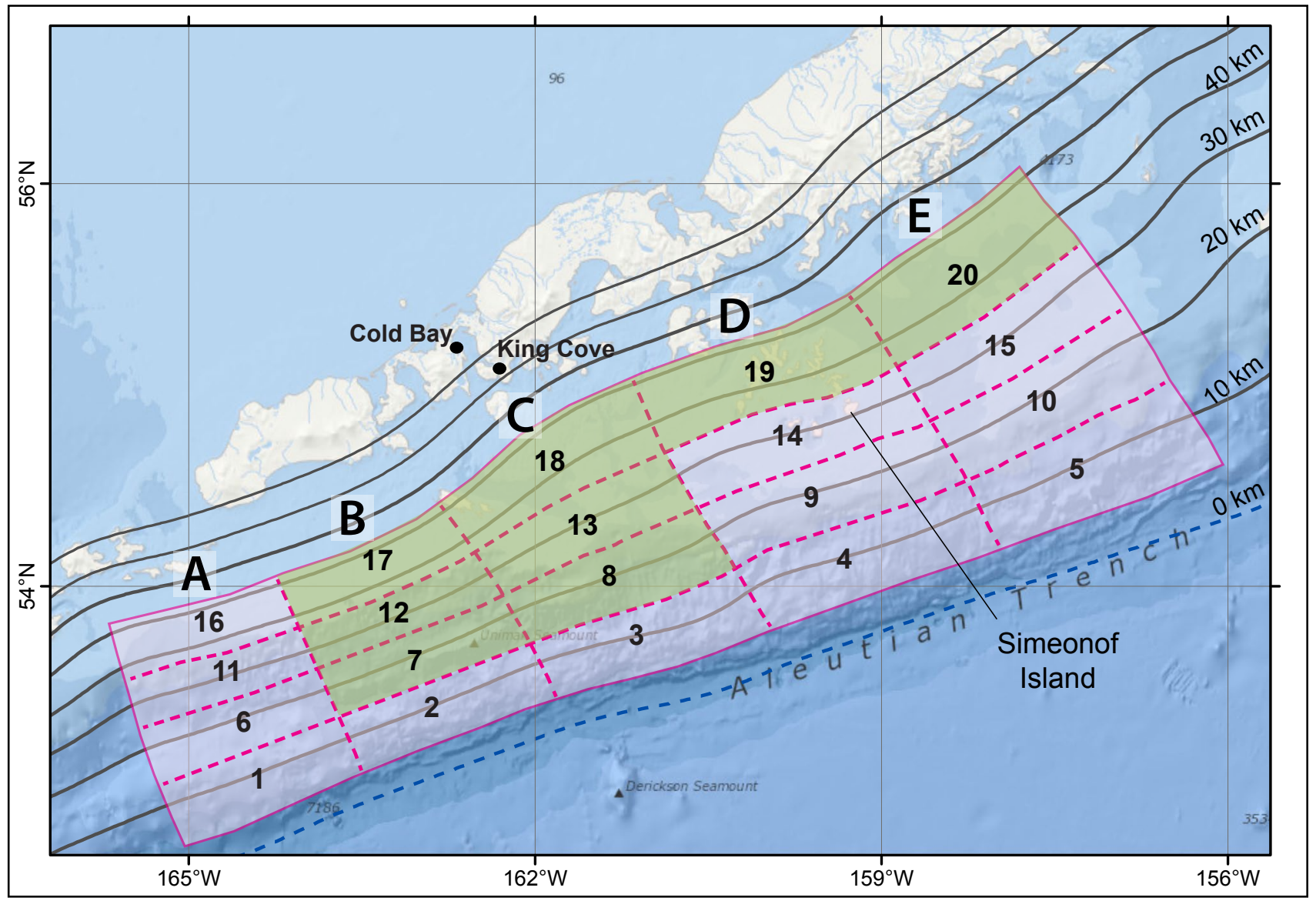

Figure 13. Mosaic of the plate interface in the study area used for the construction of hypothetical ruptures. Green-shaded area indicates segments that have zero amount of slip in some scenarios due to different geodetic and geologic constraints. 
Scenario 6. $\mathrm{M}_{\mathrm{W}} 8.3$ earthquake in the western Alaska Peninsula region: Western asperity only

This event is a hypothetical $\mathrm{M}_{\mathrm{W}} 8.3$ earthquake rupturing the Aleutian megathrust. Zero slip is assigned to segments $2-5,7-10,12-15$, and 17-20. The source consists of a western asperity only. The maximum slip of $9.9 \mathrm{~m}$ (32 ft) is at a depth of 5-15 km (3-9 mi). The proposed slip distribution is shown in figure 14F; vertical coseismic deformations for this scenario are shown in figure $15 \mathrm{~F}$.

The second group of tsunami scenarios includes three sources (scenarios 7-9) that are developed under the assumption that the geodetic data are not representative of the long term, and therefore any segments of the mosaic in figure 13 can be included in a hypothetical rupture. The objective for this approach is to determine whether the inclusion of the Shumagin gap segments in a scenario will result in significantly higher runup at King Cove and Cold Bay compared to runup produced by scenarios that are constrained by geodetic and geologic data. For the scenarios in the second group, we allow the maximum slip of $50 \mathrm{~m}(164 \mathrm{ft})$ in the shallow part (segments 1-5), and the maximum slip of 35-40 m (115-131 ft) in other segments. The average and maximum slip as well as the rupture areas for scenarios 7-9 are set according to the scaling relations of Papazachos and others (2005) and Moss and Travasarou (2006).

Table 2. All hypothetical scenarios used to model tsunami runup in King Cove and Cold Bay (WAP = western Alaska Peninsula). Scenarios marked with an asterisk are the same as in the Elfin Cove, Gustavus, and Hoonah tsunami modeling study (Suleimani and others, 2015) and in the Unalaska/Dutch Harbor modeling study (Nicolsky and others, 2015). Maps of potential permanent flooding in King Cove and Cold Bay due to coseismic subsidence are given in appendix C.

\begin{tabular}{|c|c|c|c|c|c|c|c|c|}
\hline \multirow{2}{*}{$\stackrel{2}{0}$} & \multirow{2}{*}{\multicolumn{2}{|c|}{ Tectonic Scenarios }} & \multirow{2}{*}{$\begin{array}{c}\text { Depth } \\
\text { range } \\
(\mathbf{k m})\end{array}$} & \multirow{2}{*}{$\begin{array}{l}\text { Maximum } \\
\text { slip (m) }\end{array}$} & \multirow{2}{*}{$\begin{array}{l}\text { Maximum } \\
\text { Subsidence } \\
\quad(\mathbf{m})\end{array}$} & \multirow{2}{*}{$\begin{array}{l}\text { Maximum } \\
\text { Uplift } \\
\text { (m) }\end{array}$} & \multicolumn{2}{|c|}{$\begin{array}{c}\text { Vertical } \\
\text { displacement (m) }\end{array}$} \\
\hline & & & & & & & $\begin{array}{l}\text { King } \\
\text { Cove }\end{array}$ & $\begin{array}{l}\text { Cold } \\
\text { Bay }\end{array}$ \\
\hline \multirow{6}{*}{ I } & 1 & $\begin{array}{l}\mathrm{M}_{\mathrm{w}} 9.1 \text { earthquake in WAP region: } \\
\text { Two asperities and trench }\end{array}$ & $5-35$ & 50 & 7.2 & 19.9 & -0.23 & -0.11 \\
\hline & 2 & $\begin{array}{l}\mathrm{M}_{\mathrm{w}} 9.1 \text { earthquake in WAP region: } \\
\text { Two asperities, weakly connected }\end{array}$ & $5-45$ & 50 & 5.9 & 20.1 & -0.32 & -0.16 \\
\hline & 3 & $\begin{array}{l}\mathrm{M}_{\mathrm{w}} 8.9 \text { earthquake in WAP region: } \\
\text { Eastern asperity and trench }\end{array}$ & $5-35$ & 50 & 7.1 & 20.1 & -0.2 & -0.1 \\
\hline & 4 & $\begin{array}{l}\mathrm{M}_{\mathrm{w}} 9.0 \text { earthquake in WAP region: } \\
\text { Western asperity and trench }\end{array}$ & $5-45$ & 50 & 8.6 & 17.5 & -0.08 & -0.05 \\
\hline & 5 & $\begin{array}{l}\mathrm{M}_{\mathrm{w}} 8.6 \text { earthquake in WAP region: } \\
\text { Eastern asperity only }\end{array}$ & $5-45$ & 15 & 1.56 & 6.06 & -0.07 & 0.0 \\
\hline & 6 & $\begin{array}{l}\mathrm{M}_{\mathrm{w}} 8.3 \text { earthquake in WAP region: } \\
\text { Western asperity only }\end{array}$ & $5-45$ & 9.9 & 0.68 & 3.52 & 0.0 & 0.0 \\
\hline \multirow{3}{*}{ II } & 7 & $\begin{array}{l}\mathrm{M}_{\mathrm{w}} 8.9 \text { earthquake in WAP region: } \\
\text { Gap-filling event }\end{array}$ & $5-45$ & 50 & 4.7 & 19.6 & -2.77 & -1.46 \\
\hline & 8 & $\begin{array}{l}\mathrm{M}_{\mathrm{w}} 9.0 \text { earthquake in WAP region: } \\
\text { Predominantly shallow slip in the western } \\
\text { part of the rupture }\end{array}$ & $5-45$ & 49 & 5.5 & 19.0 & -1.04 & -0.5 \\
\hline & 9 & $\begin{array}{l}\mathrm{M}_{\mathrm{w}} 9.1 \text { earthquake in WAP region: } \\
\text { Predominantly shallow slip in the eastern } \\
\text { part of the rupture }\end{array}$ & $5-45$ & 50 & 6.2 & 20.3 & -1.07 & -0.48 \\
\hline \multirow{4}{*}{ III } & 10 & $\mathrm{M}_{\mathrm{w}} 9.2$ earthquake in WAP region & $7-50$ & 36.6 & 4.8 & 13.6 & -2.5 & -1.37 \\
\hline & 11 & $\mathrm{M}_{\mathrm{w}} 9.3$ earthquake in WAP region & $5-31$ & 50 & 4.9 & 22.9 & -0.39 & -0.16 \\
\hline & 12 & $\begin{array}{l}\mathrm{M}_{\mathrm{w}} 9.0 \text { earthquake according to SAFRR } \\
\text { project }\end{array}$ & $8-54$ & $55-65$ & 2.8 & 14.8 & -0.06 & -0.05 \\
\hline & 13 & $\begin{array}{l}M_{w} 9.0 \text { earthquake in WAP region: } \\
\text { SAFRR-type event }\end{array}$ & $8-54$ & 50 & 3.3 & 14.7 & -0.35 & -0.14 \\
\hline \multirow{3}{*}{ IV } & $14 *$ & $\mathrm{M}_{\mathrm{w}} 9.1$ earthquake in Eastern Aleutians & $2-45$ & 36 & 3.0 & 14.6 & -0.2 & -0.14 \\
\hline & $15^{*}$ & $\begin{array}{l}\mathrm{M}_{\mathrm{w}} 8.6 \text { outer-rise earthquake in WAP } \\
\text { region }\end{array}$ & $2-23$ & 25 & 10.5 & 2.5 & -0.05 & -0.05 \\
\hline & $16^{*}$ & $\begin{array}{l}\mathrm{M}_{\mathrm{w}} \text { 9.0-9.1 earthquake in Cascadia } \\
\text { subduction zone }\end{array}$ & $\begin{array}{c}\text { Wang and } \\
\text { others } \\
(2003)\end{array}$ & $35-45$ & 7.5 & 10.9 & 0.0 & 0.0 \\
\hline
\end{tabular}



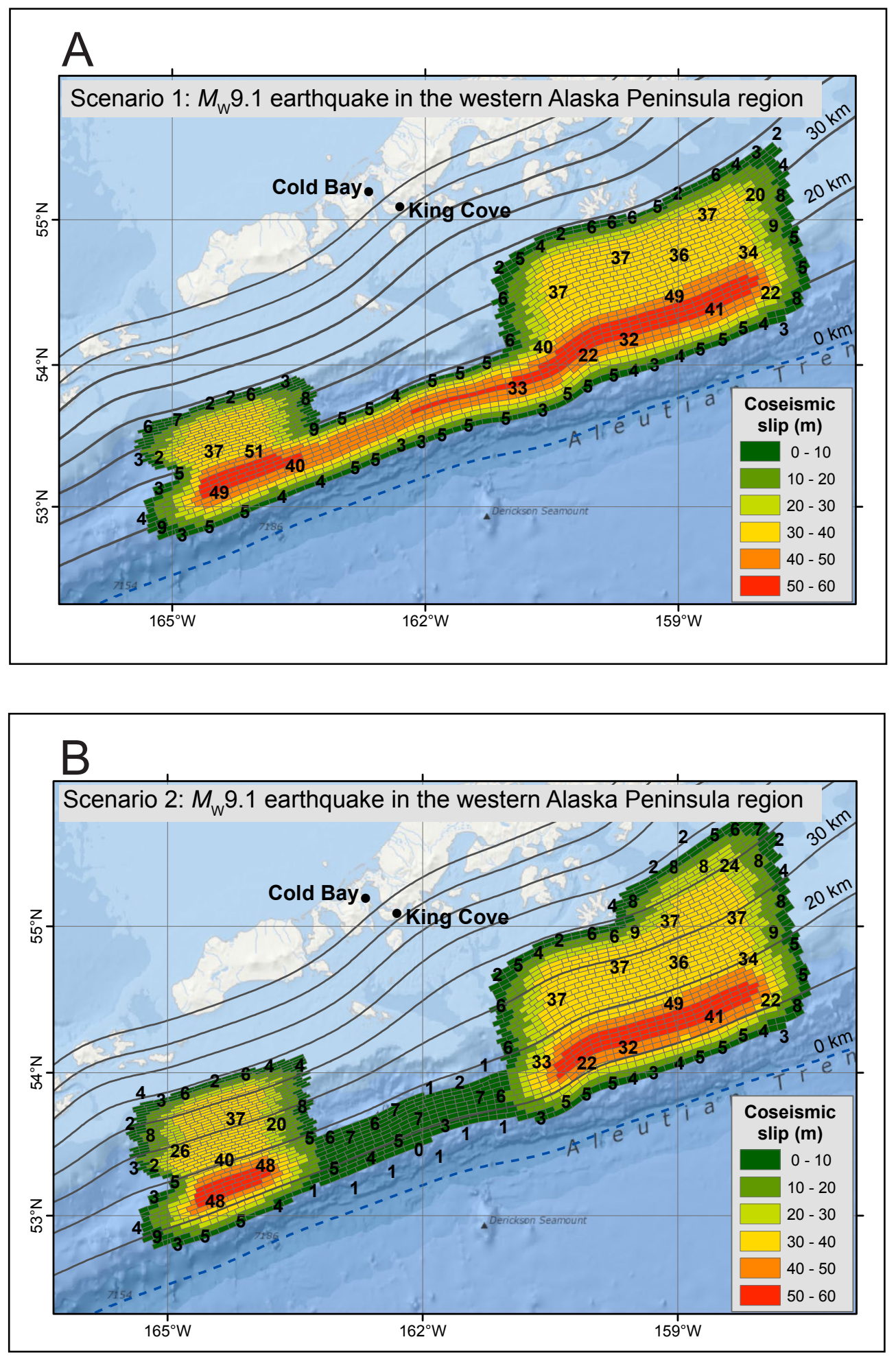

Figure 14. Proposed slip distributions along the plate interface for scenarios 1 and 2. Slip values in meters are marked by small black labels. The depth contours of the Aleutian interface are shown by black lines. 

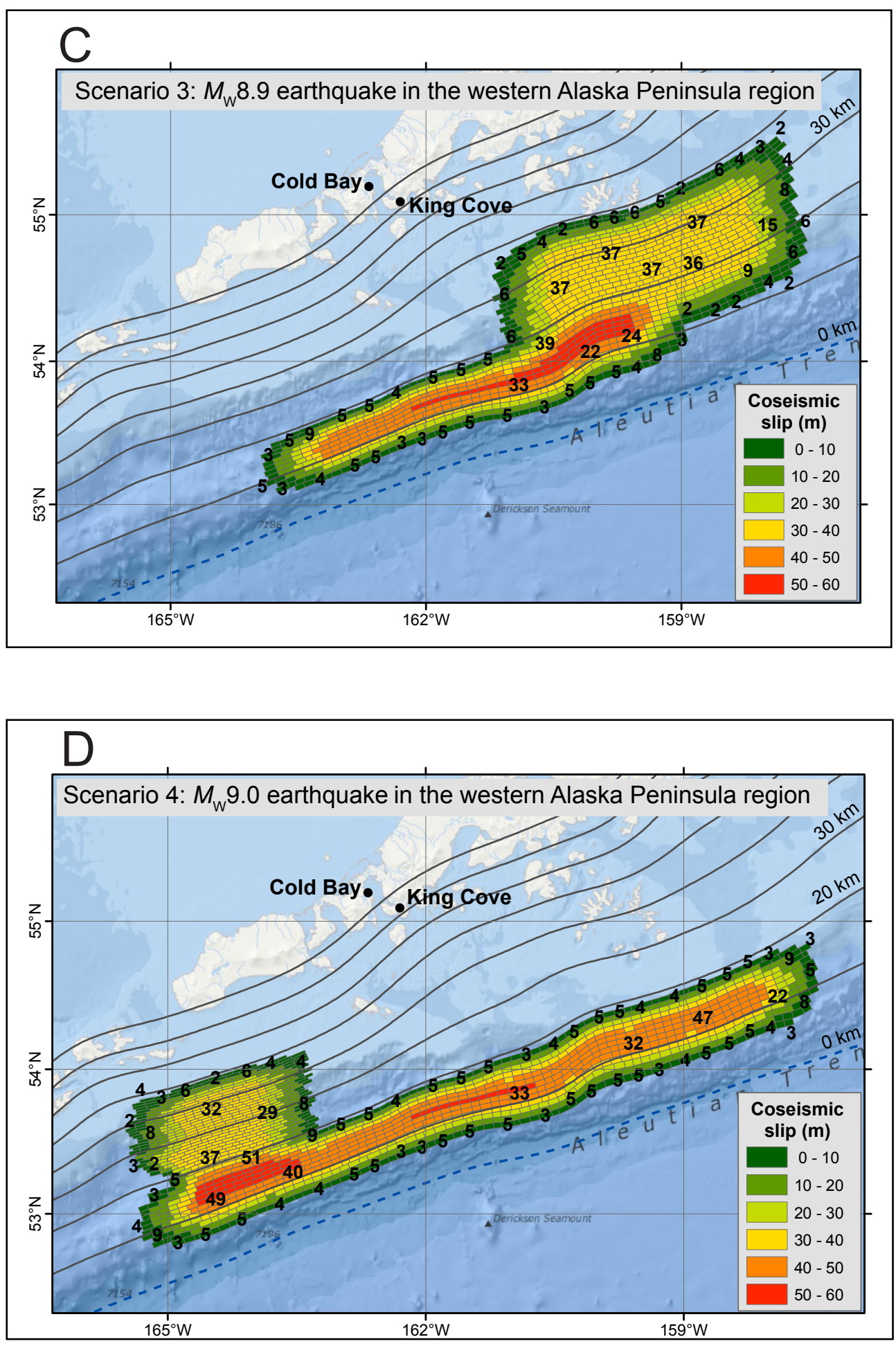

Figure 14 (cont.). Proposed slip distributions along the plate interface for scenarios 3 and 4. Slip values in meters are marked by small black labels. The depth contours of the Aleutian interface are shown by black lines. 

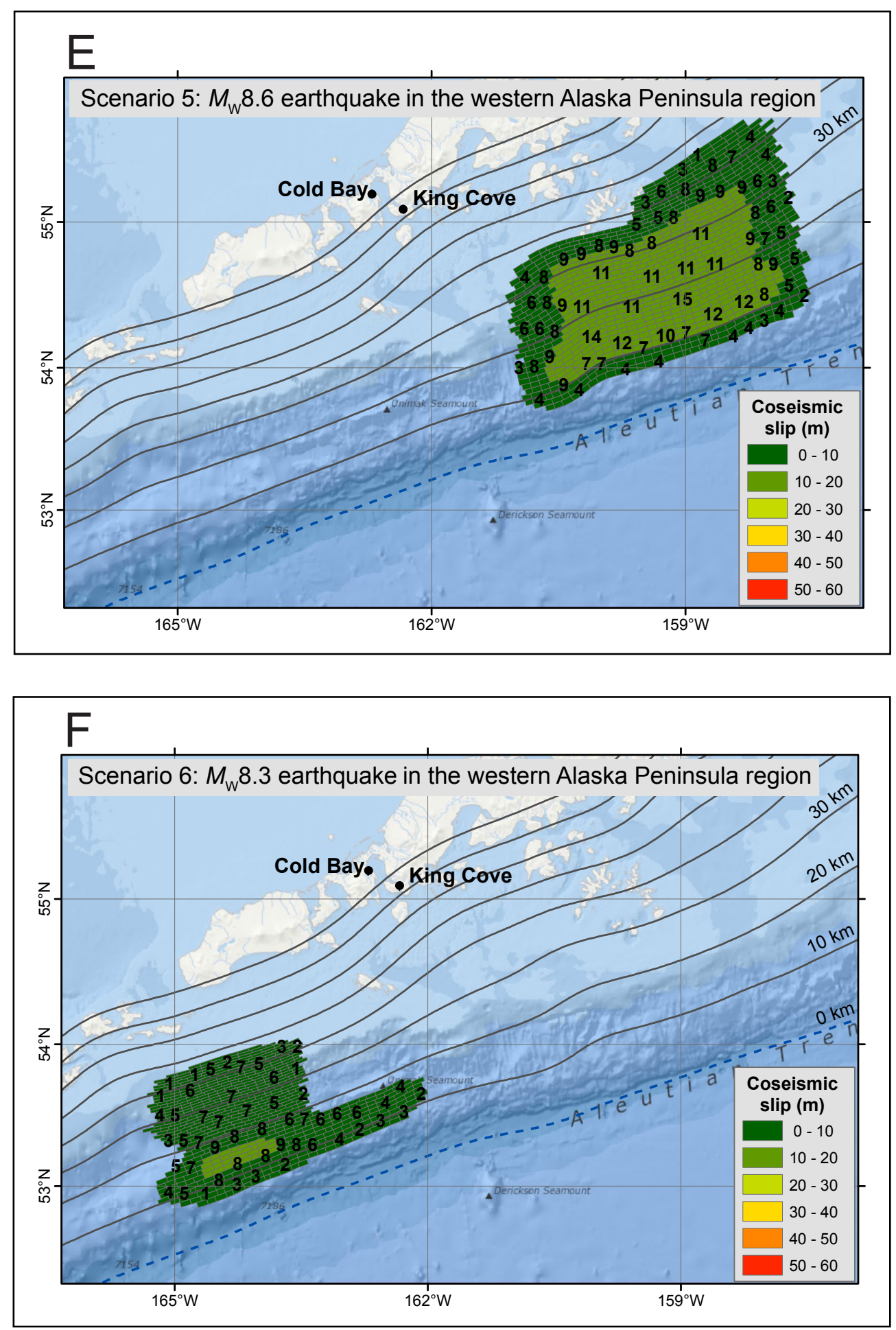

Figure 14 (cont.). Proposed slip distributions along the plate interface for scenarios 5 and 6. Slip values in meters are marked by small black labels. The depth contours of the Aleutian interface are shown by black lines. 

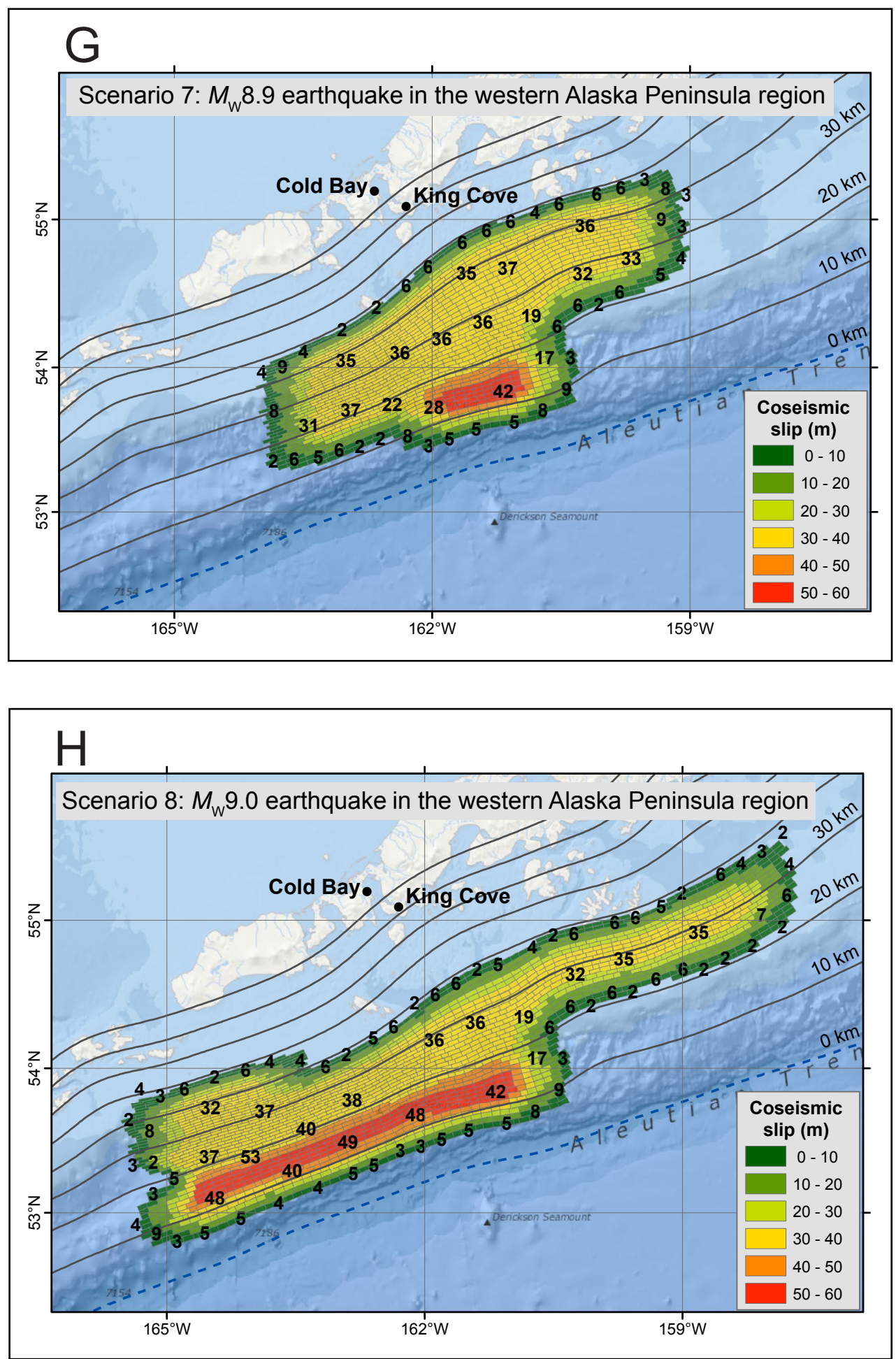

Figure 14 (cont.). Proposed slip distributions along the plate interface for scenarios 7 and 8. Slip values in meters are marked by small black labels. The depth contours of the Aleutian interface are shown by black lines. 

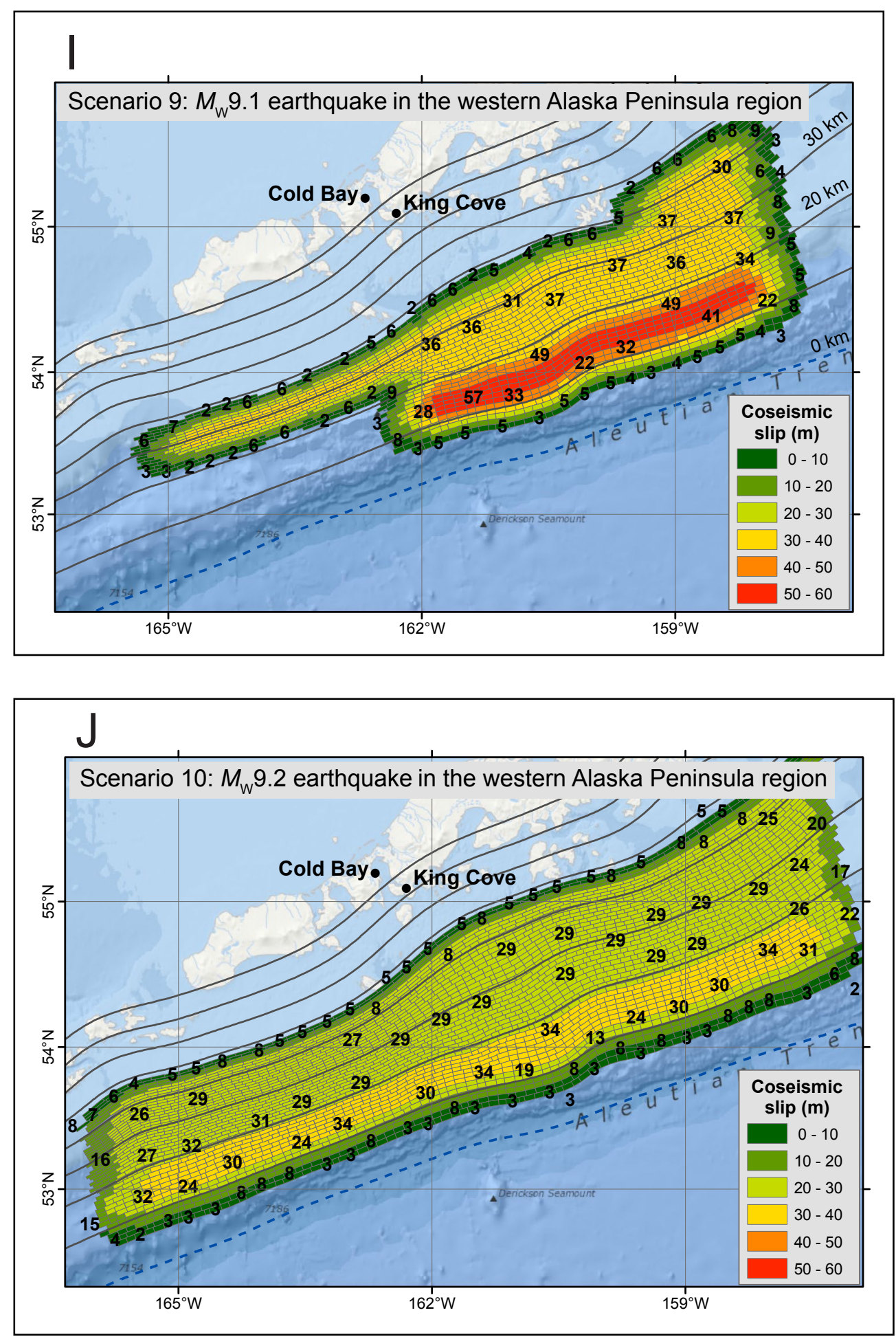

Figure 14 (cont.). Proposed slip distributions along the plate interface for scenarios 9 and 10. Slip values in meters are marked by small black labels. The depth contours of the Aleutian interface are shown by black lines. 

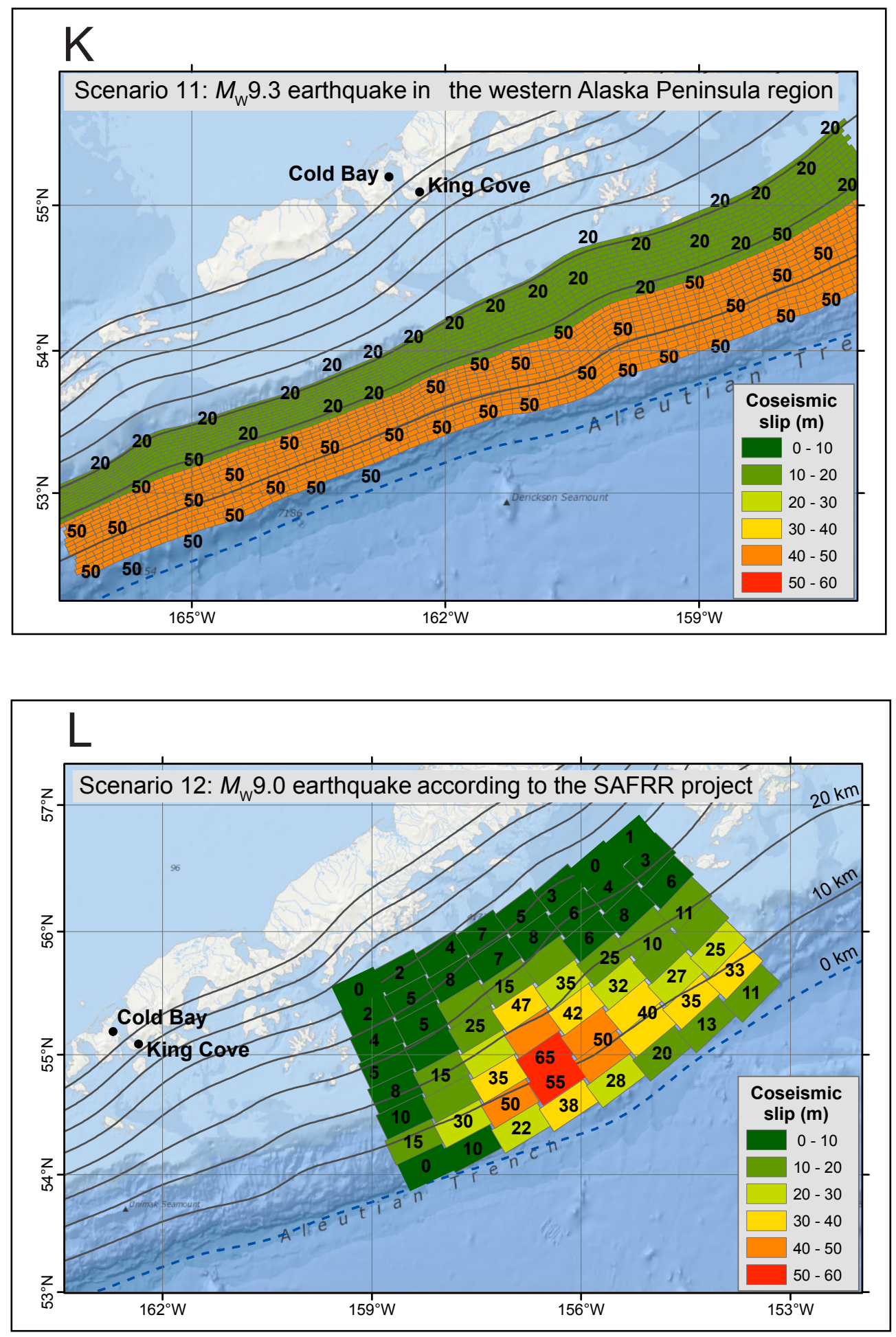

Figure 14 (cont.). Proposed slip distributions along the plate interface for scenarios 11 and 12. Slip values in meters are marked by small black labels. The depth contours of the Aleutian interface are shown by black lines. 


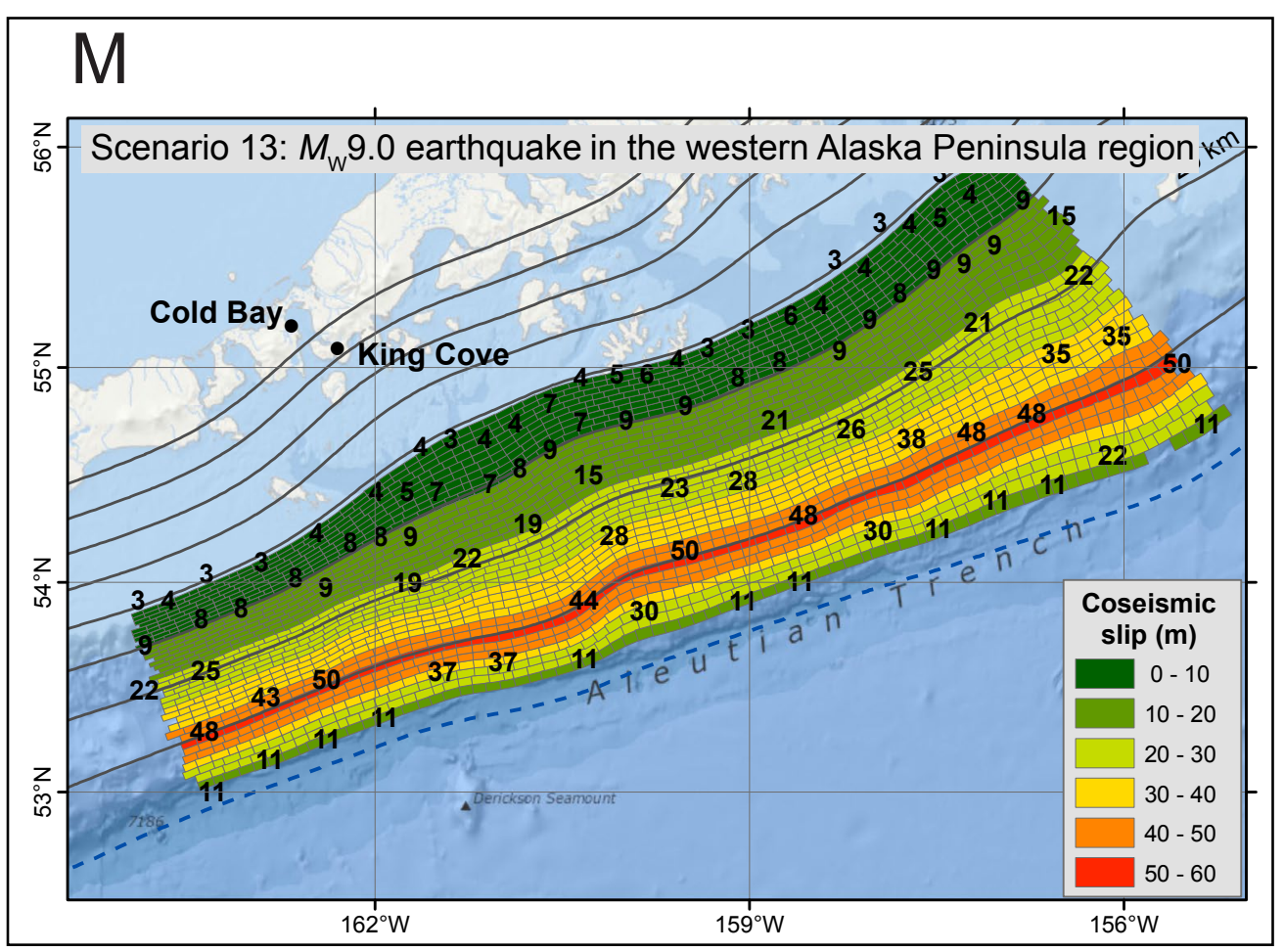

Figure 14 (cont.). Proposed slip distributions along the plate interface for scenario 13. Slip values in meters are marked by small black labels. The depth contours of the Aleutian interface are shown by black lines. 


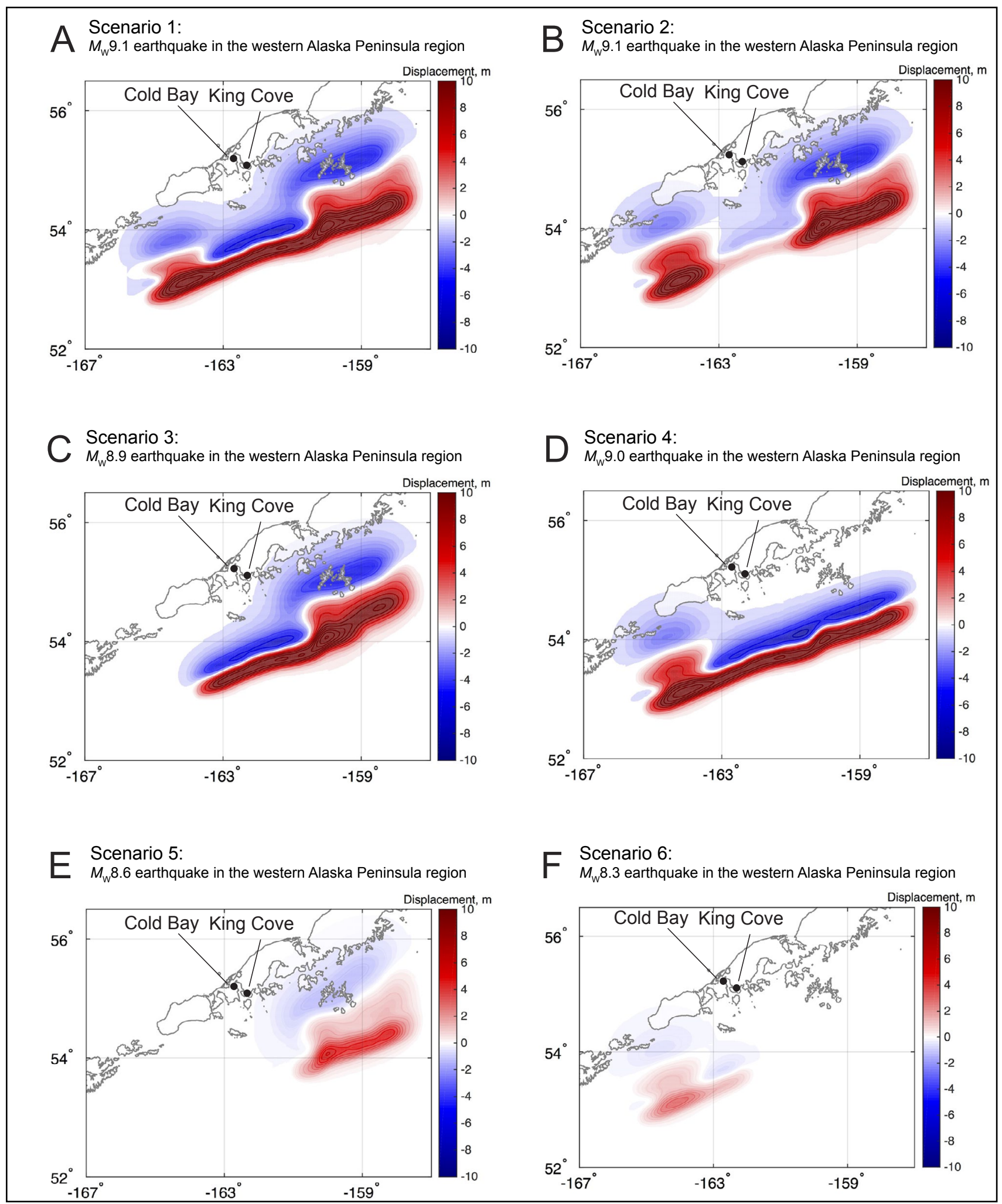

Figure 15. Vertical coseismic deformations corresponding to scenarios 1-6. Blue areas are associated with coseismic ground subsidence; areas of uplift are shown in red. 


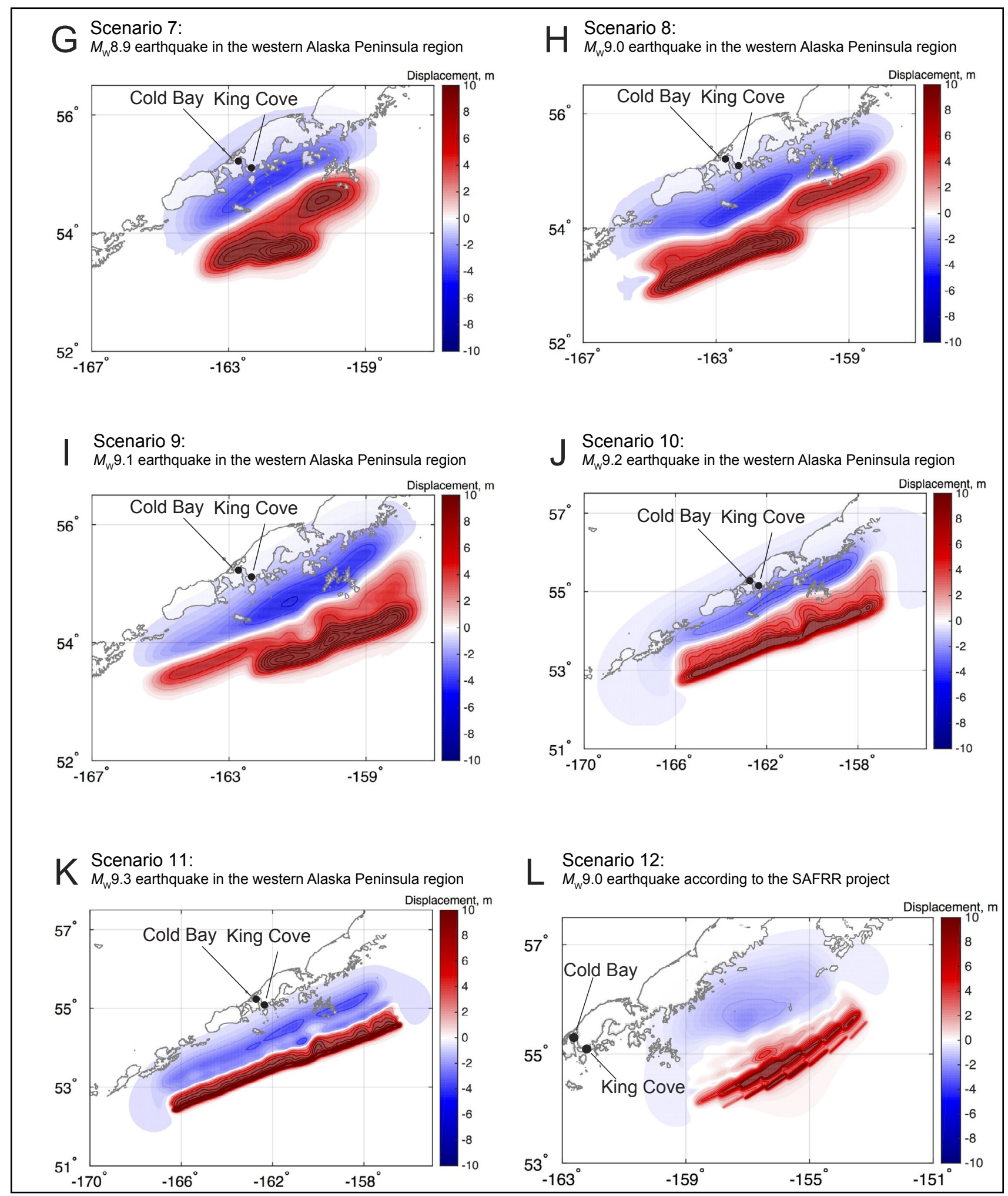

Figure 15 (cont.).Vertical coseismic deformations corresponding to scenarios 7-12. Blue areas are associated with coseismic ground subsidence; areas of uplift are shown in red. 


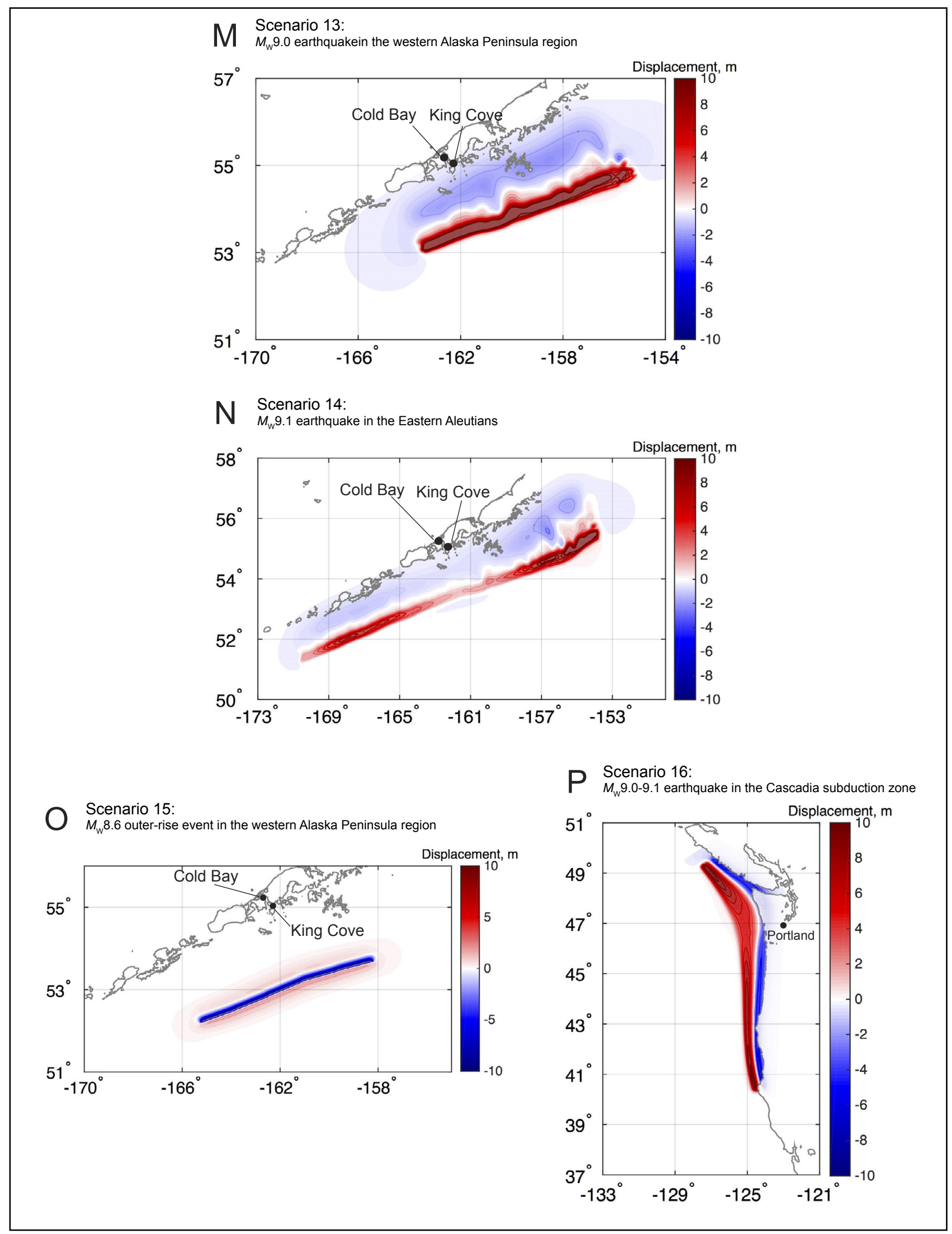

Figure 15. (cont.) Vertical coseismic deformations corresponding to scenarios 13-16. Blue areas are associated with coseismic ground subsidence; areas of uplift are shown in red. 


\section{Scenario 7. $\mathrm{M}_{\mathrm{w}} 8.9$ earthquake in the western Alaska Peninsula region: Gap-filling event}

This event is a hypothetical $\mathrm{M}_{\mathrm{W}} 8.9$ earthquake rupturing the Aleutian megathrust. Zero slip is assigned to segments 1, 2, 4-6, 9-11, 15, and 20. In this scenario, the segments representing the Shumagin gap have non-zero slip. The source consists of a patch with maximum slip of $50 \mathrm{~m}$ (164 ft) at a depth of 5-15 km (3-9 mi), and in the major part of the rupture, at a depth of $15-45 \mathrm{~km}(9-28 \mathrm{mi})$, the maximum slip is $37 \mathrm{~m}$ (121 ft). The proposed slip distribution is shown in figure $14 \mathrm{G}$; vertical coseismic deformations for this scenario are shown in figure $15 \mathrm{G}$.

Scenario 8. $\mathrm{M}_{\mathrm{W}} 9.0$ earthquake in the western Alaska Peninsula region: Predominantly shallow slip in the western part of the rupture

This event is a hypothetical $\mathrm{M}_{\mathrm{W}} 9.0$ earthquake rupturing the Aleutian megathrust. Zero slip is assigned to segments $4,5,10$, and 17-20. The source consists of a western asperity that is spread downdip between 5 and $45 \mathrm{~km}$ (3.1-28 mi) depth, and a narrow segment in the eastern part of the rupture at a depth of 20-40 km (12-25 mi). In this scenario, the segments representing the Shumagin gap have non-zero slip. The western asperity has the maximum slip of $50 \mathrm{~m}(164 \mathrm{ft})$ at a depth of 5-15 km (3-9 mi), close to the trench, and in the rest of the rupture

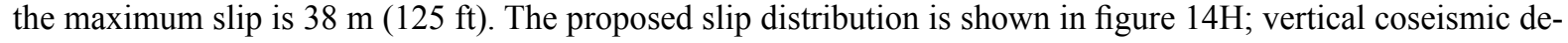
formations for this scenario are shown in figure $15 \mathrm{H}$.

Scenario 9. $\mathrm{M}_{\mathrm{W}} 9.1$ earthquake in the western Alaska Peninsula region: Predominantly shallow slip in the eastern part of the rupture

This event is a hypothetical $\mathrm{M}_{\mathrm{W}} 9.1$ earthquake rupturing the Aleutian megathrust. Zero slip is assigned to segments 1, 2, 6, 7, and 16-19. The source consists of an eastern asperity that is spread downdip between 5 and 45 $\mathrm{km}(3.1-28 \mathrm{mi})$ depth, and a narrow segment in the western part of the rupture at a depth of 30-45 km (18.6-28 $\mathrm{mi})$. In this scenario, the segments representing the Shumagin gap have non-zero slip. The eastern asperity has the maximum slip of $57 \mathrm{~m}(187 \mathrm{ft})$ at a depth of 5-15 km (3-9 mi), close to the trench, and in the rest of the rupture the maximum slip is $37 \mathrm{~m}(121 \mathrm{ft})$. The proposed slip distribution is shown in figure 14I; vertical coseismic deformations for this scenario are shown in figure 15I.

The third group of tsunami scenarios includes four sources (scenarios 10-13) that represent great megathrust earthquakes with rupture areas extending from the eastern Aleutian Islands to the western Alaska Peninsula.

A recent study by Butler and others (2014) describes a layer of sand that was discovered in the Makauwahi sinkhole on the island of Kaua'i, Hawai'i. The origin of this layer is attributed to inundation of the sinkhole by a giant paleotsunami following a $\mathrm{M}_{\mathrm{W}} 9+$ earthquake in the eastern Aleutian Islands. It is hypothesized that the great earthquake was located between the source regions of the 1946 and 1957 earthquakes and had a magnitude larger than 9.3. Butler (2012) provides an in-depth examination of previous great Aleutian earthquakes and tsunamis impacting Hawai'i. Butler (2014) considered several hypothetical events with a $35 \mathrm{~m}(115 \mathrm{ft})$ displacement on the megathrust and up to $50 \mathrm{~m}(164 \mathrm{ft})$ displacement near the trench. Thus we consider two scenarios as follows.

\section{Scenario 10. $\mathrm{M}_{\mathrm{W}} 9.2$ earthquake in the western Alaska Peninsula region}

In this scenario we assume $35 \mathrm{~m}$ (115 ft) slip on the plate interface and up to $46 \mathrm{~m}(151 \mathrm{ft})$ slip near the trench. The slip is distributed almost uniformly along strike except for the edges of the rupture, where it tapers. The proposed slip distribution is shown in figure $14 \mathrm{~J}$; vertical coseismic deformations for this scenario are shown in figure $15 \mathrm{~J}$.

\section{Scenario 11. $\mathrm{M}_{\mathrm{W}} 9.3$ earthquake in the western Alaska Peninsula region}

In this scenario similar to Butler (2014) we assume a $20 \mathrm{~m}(65 \mathrm{ft})$ slip on the plate interface between the $17.9 \mathrm{~km}$ $(11.1 \mathrm{mi})$ and $30.8 \mathrm{~km}(19.1 \mathrm{mi})$ depth, and up to a $50 \mathrm{~m}$ (164 ft) slip near the trench, that is, between $5 \mathrm{~km}(3.1 \mathrm{mi})$ and $17.9 \mathrm{~km}(11.1 \mathrm{mi})$ depth. The slip is distributed uniformly along strike. According to the USGS letter (Butler, 2014, Appendix 2), this so-called 50/20 slip model "is starting to approach that more realistic model" that could occur in the Aleutian Islands. The proposed slip distribution is shown in figure 14K; vertical coseismic deformations for this scenario are shown in figure $15 \mathrm{~K}$.

In light of the recent $\mathrm{M}_{\mathrm{W}} 9.0$ earthquake off the Pacific coast of Tohoku in 2011, we consider a similar event along the Aleutian megathrust (David Scholl, USGS, oral commun., 2013). During the Tohoku earthquake a large amount of slip occurred between the subducting and overriding plates near the Japan trench (Fujii and others, 2011; Shao and others, 2011). The USGS Science Application for Risk Reduction (SAFRR) project, in collaboration with NOAA and State of California agencies, has developed a plausible hypothetical tsunami scenario (Kirby and others, 2013) to describe the impacts of a tsunami generated by an earthquake in the Alaska Peninsula region (Ross and others, 2013). The USGS Tsunami Source Working Group defined the scenario source as a $\mathrm{M}_{\mathrm{W}} 9.0$ earthquake similar to the Tohoku 2011 event but located between 
the Shumagin Islands and Kodiak Island. The rupture area, represented by 56 subfaults, is about $350 \times 200 \mathrm{~km}(217 \times 124$

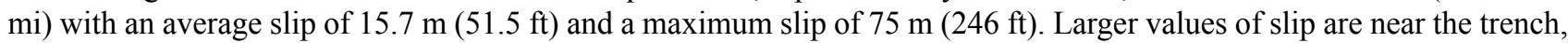
as for the Tohoku earthquake.

\section{Scenario $12 . \mathrm{M}_{\mathrm{W}} 9.0$ earthquake according to the SAFRR project}

This scenario is the same as scenario 5 in the tsunami modeling study for Elfin Cove, Gustavus, and Hoonah (Suleimani and others, 2015). The proposed slip distribution is shown in figure 14L; vertical coseismic deformations for this scenario are shown in figure $15 \mathrm{~L}$.

\section{Scenario 13. $\mathrm{M}_{\mathrm{W}} 9.0$ earthquake in the western Alaska Peninsula region: SAFRR-type event}

In this scenario we assume that the slip distribution in the downdip direction is the same as that in the SAFRR source (scenario 12), where greater slip occurs closer to the trench. This hypothetical rupture is shifted westward along the trench to be positioned across the shelf area from the communities of King Cove and Cold Bay. The slip is distributed almost uniformly along strike except for the edges of the rupture where it tapers. The proposed slip distribution is shown in figure 14M; vertical coseismic deformations for this scenario are shown in figure $15 \mathrm{M}$.

The fourth group of scenarios includes tsunami sources that have been considered in previous tsunami inundation mapping studies. Refer to the corresponding report for the detailed description of the source.

\section{Scenario 14. $\mathrm{M}_{\mathrm{W}} 9.1$ earthquake in the eastern Aleutians ${ }^{4}$}

This scenario is the same as scenario 6 in the tsunami modeling study for Elfin Cove, Gustavus, and Hoonah (Suleimani and others, 2015). It is based on the slip model of a hypothetical earthquake that incorporates the entire rupture areas of the 1938 and 1946 events as well as the eastern end of the 1957 rupture zone (Ryan and others, 2012). To construct a source model, we place the largest amount of slip at the eastern end, which is a nearly fully locked segment of the megathrust beneath the Semidi Islands, based on GPS studies by Freymueller and others (2008). We assign a much smaller amount of slip to the middle part of the rupture, where coupling of the plate interface changes from about 30 percent locked at the Shumagin Islands to freely slipping west of the Shumagins (Fournier and Freymueller, 2007). The amount of slip increases again at the western end of the rupture, where little moment was released in 1957. The vertical coseismic deformations for this scenario are shown in figure $15 \mathrm{~N}$.

Scenario 15. Rupture of the tensional outer-rise part of the subduction plate south of the trench in the area of the western Alaska Peninsula ${ }^{4}$

This scenario is the same as scenario 10 in the tsunami modeling study for Unalaska/Dutch Harbor (Nicolsky and others, 2015). The only difference is in the geographic location of the rupture, which is reflected in the coordinates of subfaults listed in table 3 . The vertical coseismic deformations for this scenario are shown in figure 150 .

\section{Scenario 16. Rupture of the Cascadia zone including the entire megathrust between British Columbia} and northern California ${ }^{4}$

This scenario is the same as scenario 7 in the tsunami modeling study for Elfin Cove, Gustavus, and Hoonah (Suleimani and others, 2015). The vertical coseismic deformations for this scenario are shown in figure 15P.

Table 3. Fault parameters for the hypothetical tensional Mw 8.6 outer-rise earthquake.

\begin{tabular}{|c|c|c|c|c|c|c|c|c|}
\hline $\begin{array}{c}\text { Latitude } \\
\left({ }^{\circ} \mathbf{N}\right)\end{array}$ & $\begin{array}{c}\text { Longitude } \\
\left({ }^{\circ} \mathbf{W}\right)\end{array}$ & $\begin{array}{c}\text { Depth } \\
(\mathbf{k m})\end{array}$ & $\begin{array}{c}\text { Length } \\
(\mathbf{k m})\end{array}$ & $\begin{array}{c}\text { Width } \\
(\mathbf{k m})\end{array}$ & Strike $\left.\mathbf{(}^{\circ}\right)$ & $\begin{array}{c}\text { Dip } \\
\left(\mathbf{\circ}^{\circ}\right.\end{array}$ & $\begin{array}{c}\text { Rake } \\
\left({ }^{\circ}\right)\end{array}$ & $\begin{array}{c}\text { Slip } \\
(\mathbf{m})\end{array}$ \\
\hline $52^{\circ} 49^{\prime} 26^{\prime \prime}$ & $162^{\circ} 27^{\prime} 43^{\prime \prime}$ & 2 & 100 & 15 & 252.32 & 45 & -90 & 25 \\
\hline $52^{\circ} 28^{\prime} 58^{\prime \prime}$ & $163^{\circ} 50^{\prime} 42^{\prime \prime}$ & 2 & 100 & 15 & 251.71 & 45 & -90 & 25 \\
\hline $53^{\circ} 40^{\prime} 48^{\prime \prime}$ & $158^{\circ} 11^{\prime} 06^{\prime \prime}$ & 2 & 100 & 15 & 250.15 & 45 & -90 & 25 \\
\hline $53^{\circ} 26^{\prime} 17^{\prime \prime}$ & $159^{\circ} 38^{\prime} 52^{\prime \prime}$ & 2 & 100 & 15 & 247.56 & 45 & -90 & 25 \\
\hline $53^{\circ} 10^{\prime} 44^{\prime \prime}$ & $161^{\circ} 05^{\prime} 09^{\prime \prime}$ & 2 & 100 & 15 & 247.42 & 45 & -90 & 25 \\
\hline
\end{tabular}

\footnotetext{
${ }^{4}$ Scenarios are the same as in the Elfin Cove, Gustavus, and Hoonah tsunami modeling study (Suleimani and others, 2015) and the Unalaska/Dutch Harbor modeling study (Nicolsky and others, 2015).
} 


\section{MODELING RESULTS}

We performed numerical calculations for all 16 scenarios described above and summarized in table 2. For each scenario, we modeled the water dynamics for each grid in table 1 and computed the extent of inundation and flow depths only for the high-resolution grids. Map sheets 1 (King Cove) and 2 (Cold Bay) show the maximum composite extent of inundation for all scenarios, and the maximum composite flow depths over dry land. The calculated extent of inundation accommodates coseismic deformation in the communities.

\section{King Cove}

The simulated extents of tsunami inundation in King Cove for eight selected scenarios are shown in figure 16. For the sake of clarity we do not plot the inundation lines for all 16 scenarios, because some of the tsunami sources produced very similar inundation zones. Instead, we choose the most representative scenarios from each of the first three groups, and also plotted the inundation line for every scenario in the fourth group because the sources in that group represent different geographic regions and/or earthquake parameters. However, we calculated the composite inundation line shown on map sheet 1 using results from all 16 hypothetical scenarios, and we also include limits of inundation for all scenarios in the data distribution package for this report.

For scenario-specific results, we focus on the industrial center of the community because we find a greater variability in tsunami inundation limits in this area (fig. 16). This low-elevation part of King Cove is on a sand spit between King Cove Lagoon and King Cove Harbor and is connected by a bridge to the small boat harbor, the new King Cove harbor, and harbor facilities. Scenarios 2 (group 1), 7 (group 2), and 11 (group 3) all produce an extreme tsunami runup at King Cove, inundating the entire spit, the harbor facilities, and Ram's Creek Road, which goes to the southeastern part of the community. Tsunami wave heights at the Peter Pan powerhouse (point 17), accounting for local subsidence, reach $4.1 \mathrm{~m}(13.5 \mathrm{ft})$, $12.2 \mathrm{~m} \mathrm{(40} \mathrm{ft),} \mathrm{and} 6.6 \mathrm{~m}(21.7 \mathrm{ft})$ for scenarios 2, 7, and 11, respectively. Although we used different considerations and constraints to develop these tsunami scenarios, all result in similar inundation zones, which shows that any local megathrust event with magnitude $\mathrm{M}_{\mathrm{W}} 8.9$ or higher will very likely generate a damaging tsunami at King Cove.

Scenario 6 (western asperity, $M_{\mathrm{W}} 8.3$ ) does not result in any inundation at King Cove, while scenario 5 (eastern asperity, $\mathrm{M}_{\mathrm{W}}$ 8.6) makes a wave that inundates the tip of the spit and the harbor facilities (pink line in fig. 16). The wave height at the Communications Building (point 20) is $0.77 \mathrm{~m}$ (2.5 ft) for this scenario. Scenario 12, a hypothetical Tohoku-type earthquake (considered in the SAFRR project) between Shumagin and Kodiak Island, also results in an insignificant inundation area (red line in fig. 16) and produces a $2 \mathrm{~m}(6.6 \mathrm{ft}$ ) wave at the Fuel Shack (point 14). This hypothetical tsunami event might flood only a few low-lying areas close to the shoreline.

Scenarios in the fourth group produce less inundation in King Cove compared to the other scenario groups. Scenarios 15 and 16 produce inundation areas that are slightly smaller than that of scenario 5, but both also inundate the harbor facilities. Only the tip of the spit adjacent to the bridge is inundated, with wave heights of $0.25 \mathrm{~m}(0.82 \mathrm{ft})$ for scenario 15 and 0.1 $\mathrm{m}(0.33 \mathrm{ft})$ for scenario 16 at the Communications Building (point 20). The largest inundation area in this scenario group is produced by scenario 14, the $\mathrm{M}_{\mathrm{W}} 9.1$ earthquake in the eastern Aleutians. King Cove and Cold Bay are across the shelf area from the middle part of this rupture, where much smaller vertical coseismic deformations are present compared to the remainder of the rupture area (fig. $15 \mathrm{~N}$ ). Therefore, the resulting inundation area is much smaller than that produced by a similar event but with uniform slip distribution along strike (scenario 11, figs. 14K and 15K). Scenario 14 makes a wave that inundates a larger part of the spit than in scenarios 15 and 16, including the Peter Pan facility (cyan line in fig. 16). The wave height at the Communications Building (point 20) is $1.6 \mathrm{~m}(5.2 \mathrm{ft}$ ) for this scenario.

Map sheet 1 shows the composite inundation line and flow depths over dry land for the entire community that continues along the eastern side of King Cove Harbor. The whole spit and harbor facilities are in the inundation zone, with flow depths reaching almost $15 \mathrm{~m}$ (49 ft). The northern section of Ram's Creek Road would be flooded, as well as the part of the road in the southeastern section of the community that connects Ram's Creek Loop and Solcum Drive.

The numerical simulations reveal that for some scenarios (for example, scenarios 7, 8, and 10) the first wave could arrive at King Cove within 1 hour after the earthquake. Our sensitivity study for the King Cove and Cold Bay areas demonstrated that waves coming from different segments of the rupture area might constructively interfere later, after the arrival of the first wave, and cause runup comparable to that produced by the first wave. Significant wave activity could continue in King Cove for at least 12 hours after the earthquake, and the predicted average time interval between successive waves is between 1 and 1.5 hours.

\section{Cold Bay}

The tsunami inundation modeling results indicate that the community of Cold Bay is well protected from tsunami hazards (map sheet 2). The village is on relatively high ground, thus the only two locations that get inundated are the low-lying deltas of the two creeks, one to the north of the community and one to the south. Neither inundation area extends far enough to reach the airport runways. A narrow, inundated strip along the shoreline is predicted to have flow depths reaching about $3 \mathrm{~m}(10 \mathrm{ft})$, but the community is above the composite inundation line. The numerical simulations reveal that the first wave could arrive at Cold Bay within about 1.5 hours of the earthquake for some scenarios (for example, scenarios 7, 8, and 10), 


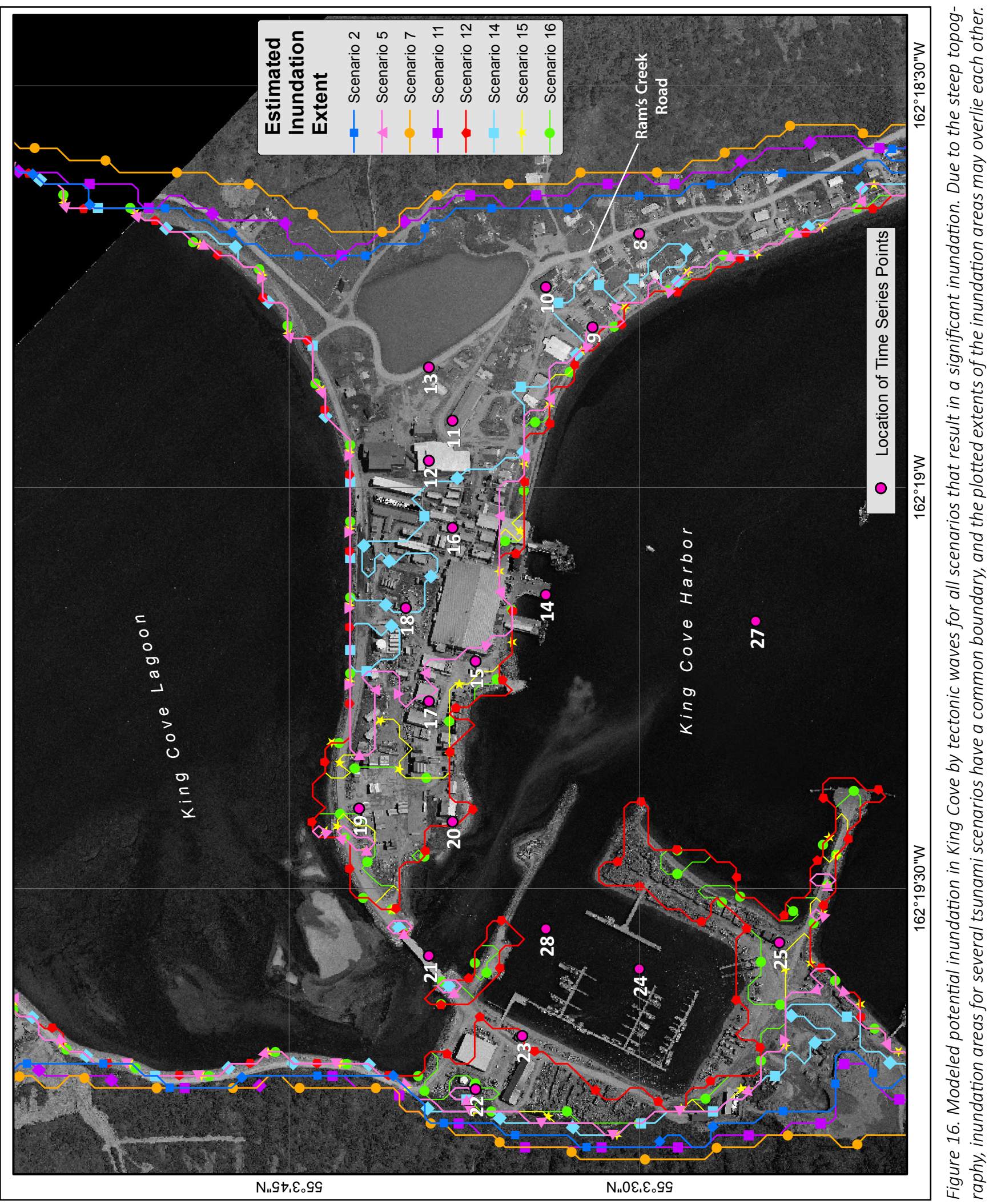


whereas the highest wave might arrive 3 hours after the earthquake (scenario 10). Significant wave activity might continue for at least 24 hours after the earthquake, and the predicted average time interval between successive waves is about 1.5 hours.

Comparison of the potential tsunami impact in the communities of King Cove and Cold Bay shows that the near-shore ground elevations in a community as well as its geographic location are critical factors that affect the community's vulnerability to tsunami waves. While all of the local tsunami sources produce waves that completely inundate the majority of King Cove, the same scenarios result in little to no inundation at Cold Bay.

\section{TIME SERIES AND OTHER NUMERICAL RESULTS}

To help emergency managers assess the tsunami hazard in King Cove and Cold Bay we supplement the inundation maps with the time series of the modeled water level and velocity dynamics at certain locations around the communities (appendices A and B). For each labeled location in figures A-1 and B-1 we plot the sea level and water velocity in figures A-2, A-3, B-2, and B-3, respectively. Zero time corresponds to the time when the earthquake occurs. The pre-earthquake elevation/depth with respect to the MHHW is stated for each location. The post-earthquake elevations/depth corresponding to the MHHW datum are also listed for each scenario. For some onshore locations, the post-earthquake value could be referenced as "depth" for some scenarios, and as "elevation" for others, indicating that different scenarios resulted in different amounts of coseismic subsidence. To show the height of arriving tsunamis for offshore locations we use a vertical datum with a zero mark corresponding to the pre-earthquake sea level. The dashed lines show final water levels after the tsunami. Velocity magnitude is calculated as water flux divided by water depth, thus the velocity value can have large uncertainties when the water depth is small. In the plots provided, the velocity is computed only where the water depth is greater than $0.3 \mathrm{~m}(1 \mathrm{ft})$. Since scenarios 10-12 produce comparable tsunami wave amplitudes at almost all locations (table A-1), for clarity we choose scenario 10 to represent this group in time series.

Analysis of the time series plot for King Cove shows that a local hypothetical earthquake with a magnitude greater than 8.6 (for example, scenarios 1-4 and 7-11) can create a devastating wave that completely floods the sand spit that separates King Cove Harbor from King Cove Lagoon, and where the majority of businesses, including the Peter Pan seafood processing facility, are located. The water level near the Peter Pan facility (point 15) could reach $9.7 \mathrm{~m}(31.8 \mathrm{ft}$ ) in scenario 7. Unsecured shipping containers could be lifted by tsunami waves and hit other buildings. Numerical modeling also predicts that tsunami currents in both King Cove harbors and near the bridge could reach dangerous velocities. For example, tsunami currents near the bridge (point 21) could reach a velocity of $8.9 \mathrm{~m} / \mathrm{s}(29.2 \mathrm{ft} / \mathrm{s}$, or $17.3 \mathrm{kt}$ ) in scenario 8 ; tsunami currents near the King Cove Harbor House (point 25) could reach a velocity of $10.7 \mathrm{~m} / \mathrm{s}(35.1 \mathrm{ft} / \mathrm{s}$, or $20.8 \mathrm{kt})$ in scenario 11 . It could also be possible for eddies to form near the harbor entrances and travel across the bay.

All local scenarios predict little inundation in the village of Cold Bay. The only ground location that has non-zero tsunami amplitudes is Reeve Avenue, south of the airport (point 3), with a predicted wave height of $5.8 \mathrm{~m} \mathrm{(19} \mathrm{ft)} \mathrm{in} \mathrm{scenario}$ 7. This uninhabited area gets flooded due to its low elevation, while the rest of the community is on higher ground and thought to be safe. The maximum water level and velocity for all considered scenarios are listed in tables B-1 and B-2, respectively. Numerical modeling predicts that tsunami currents at the City Dock (point 2) could reach a velocity of 1.8 $\mathrm{m} / \mathrm{s}(5.9 \mathrm{ft} / \mathrm{s}$, or $3.5 \mathrm{kt})$ in scenario 8 . Tsunami inundation of Cold Bay is minimal not only due to the higher elevation of the village, but also because some of the tsunami energy dissipates before reaching Cold Bay due to shallow bathymetry between Deer Passage and Cold Bay (fig. 2). Resulting tsunami wave amplitudes at the entrance to King Cove Harbor (point 1) are larger for all scenarios than the tsunami amplitudes at the entrance to Cold Bay, and at least twice as large for 12 of 16 considered scenarios.

\section{SOURCES OF ERRORS AND UNCERTAINTIES}

The hydrodynamic model used to calculate propagation and runup of tsunami waves is a nonlinear, flux-formulated, shallow-water model (Nicolsky and others, 2011b) that has passed the validation and verification tests required for models used in production of tsunami inundation maps (Synolakis and others, 2007; NTHMP, 2012). The limitations of the employed modeling approach are described in detail in earlier reports by Suleimani and others $(2010,2013,2015)$ and Nicolsky and others (2011a, 2011b, 2013, 2014, 2015), as well as in NTHMP (2012).

\section{SUMMARY}

We present the results of numerical modeling of earthquake-generated tsunamis for King Cove and Cold Bay, Alaska. Hypothetical scenarios 2, 7, 10 and 11 (thrust earthquakes in the eastern Aleutians - western Alaska Peninsula region, with magnitudes ranging from $M_{w} 8.9$ to $M_{w} 9.3$, which have their greatest slip at 10-20 km [6-12 mi] depth) result in the "worst case" tsunami inundation hazards for King Cove. The same tsunami scenarios, however, result in little inundation for the Cold Bay community because of its higher elevation above sea level and also because the energy of tsunami waves dissipates in the shallow entrance to Cold Bay before they reach the village. The scenarios predict very strong tsunami currents in Cold Bay. 
We emphasize that each of the scenarios considered are geologically reasonable and consistent with what we know about the earthquake history of the region. Scenarios 1-6, in particular, are consistent with current interpretations of all existing geologic and geodetic data. The maximum slip in the scenario earthquakes is similar to that of the Tohoku earthquake, an arbitrary amount but plausible worst case. All scenarios present potential hazards to each community. Map sheets 1 and 2, which show the results of our modeling for King Cove and Cold Bay, have been completed using the best information available and are believed to be accurate; however, their preparation required many assumptions. We considered several tectonic scenarios and provided an estimate of maximum credible tsunami inundation for each scenario. Actual conditions during a tsunami event may vary from those considered, so the accuracy cannot be guaranteed. The limits of inundation shown should be used only as a guideline for emergency planning and response action. Actual areas inundated will depend on specifics of the earth deformation, land construction, and tide level, and may differ from areas shown on the map. The information on this map is intended to assist state and local agencies in planning emergency evacuation and tsunami response actions in the event of a major tsunamigenic earthquake. These results are not intended for land-use regulation or building-code creation.

\section{ACKNOWLEDGMENTS}

This project received support from the National Oceanic and Atmospheric Administration (NOAA) under Reimbursable Services Agreement ADN 952011 with the State of Alaska's Division of Homeland Security \& Emergency Management (a division of the Department of Military and Veterans Affairs). Some research in this publication is sponsored by the Cooperative Institute for Alaska Research with funds from NOAA under cooperative agreement NA08OAR4320751 with the University of Alaska Fairbanks. We thank Lander Ver Hoef for his help with the RTK GPS survey in Cold Bay and King Cove. Numerical calculations for this work were supported by a grant of High Performance Computing (HPC) resources from the Arctic Region Supercomputing Center (ARSC) at the University of Alaska Fairbanks. We thank Alyssa Pampell Manis for her detailed review that helped improve the report, and also an anonymous reviewer for a number of insightful comments and suggestions.

\section{REFERENCES}

Alaska Department of Commerce, Community, and Economic Development, Division of Community and Regional Affairs (DCRA), 2013a, Cold Bay Community Profile, https://www.commerce.alaska.gov/dcra/DCRAExternal/community/ Details/043ef124-57d0-4477-803b-9803a5a64e03, Community Database Online.

Alaska Department of Commerce, Community, and Economic Development, Division of Community and Regional Affairs (DCRA), 2013b, King Cove Community Profile, https://www.commerce.alaska.gov/dcra/DCRAExternal/community /Details/836b5df4-ba45-4a74-af1d-568f90d6eeb1, Community Database Online.

Argus, D.F., Gordon, R.G., Heflin, M.B., Ma, Chopo, Eanes, R.J., Willis, Pascal, Peltier, W.R., and Owen, S.E, 2010, The angular velocities of the plates and the velocity of the Earth's centre from space geodesy: Geophysics Journal International, v. 180, no. 3, p. 913-960. doi:10.1111/j.1365-246X.2009.04463.x Don Argus kindly provided us with the GEODVEL NNR angular velocities.

Butler, Rhett, 2012, Re-examination of the potential for great earthquakes along the Aleutian island arc with implication for tsunamis in Hawai'i: Seismological Research Letters, v. 83, no. 1, p. 30-39. doi:10.1785/gssrl.83.1.29

Butler, Rhett, 2014, Great Aleutian tsunamis: Honolulu, HI, University of Hawai'i at Manoa, Hawai'i Institute of Geophysics \& Planetology, Peer-Reviewed Report HIGP-2014-1, 170 p., www.higp.hawaii.edu/reports/2014

Butler, Rhett, Burney, David, and Walsh, David, 2014, Paleotsunami evidence on Kaua'i and numerical modeling of a great Aleutian tsunami: Geophysical Research Letters, v. 41, no. 19, p. 6,795-6,802. doi:10.1002/2014GL061232

Carignan, K.S., McLean, S.J., Eakins, B.W., Beasley, L., and Love, M.R., 2013, Digital elevation models of Cold Bay and King Cove, Alaska - Procedures, data sources, and analysis: Boulder, CO, National Geophysical Data Center, NOAA, 10 p. www.ngdc.noaa.gov/dem/squareCellGrid/getReport/4953

Davies, J.N., Sykes, L.R., House, L.S., and Jacob, K.H., 1981, Shumagin seismic gap, Alaska Peninsula-History of great earthquakes, tectonic setting, and evidence for high seismic potential: Journal of Geophysical Research, v. 86, no. B5 p. 3,821-3,855. doi:10.1029/JB086iB05p03821

DeMets, Charles, Gordon, R.C., Argus, D.F., and Stein, Seth, 1990, Current plate motions: Geophysical Journal International, v. 101, no. 2, p. 425-478.

Dunbar, P.K., and Weaver, C.S., 2008, U.S. states and territories national tsunami hazard assessment-Historical record and sources for waves: Technical Report, National Oceanic and Atmospheric Administration and U.S. Geological Survey, 59 p. http://nthmp.tsunami.gov/documents/Tsunami_Assessment_Final.pdf

Estabrook, C.H., Jacob, K.H., and Sykes, L.R., 1994, Body wave and surface wave analysis of large and great earthquakes along the eastern Aleutian arc, 1923-1993; Implications for future events: Journal of Geophysical Research, v. 99, no. B6, p. 11,643-11,662. 
Fletcher, H.J., Beavan, John, Freymueller, J.T., and Gilbert, Lewis, 2001, High interseismic coupling of the Alaska subduction zone SW of Kodiak Island inferred from GPS data: Geophysical Research Letters, v. 28, no. 3, p. 443-446. doi:10.1029/2000GL012258

Fournier, T.J., and Freymueller, J.T., 2007, Transition from locked to creeping subduction in the Shumagin region, Alaska: Geophysical Research Letters, v. 34, no. 6, \#L06303. doi:10.1029/2006GLO29073

Freymueller, J.T., Woodard, H., Cohen, S., Cross, R., Elliott, J., Larsen, C., Hreinsdottir, S., and Zweck, C., 2008, Active deformation processes in Alaska, based on 15 years of GPS measurements, in Freymueller, J.T., Haeussler, P.J., Wesson, R., and Ekström, G., eds., Active Tectonics and Seismic Potential of Alaska: Washington, DC, American Geophysical Union Geophysical Monograph, v. 179, p. 1-42. doi:10.1029/179GM02

Fryer, G.J., and Watts, P., 2001, Motion of the Ugamak slide, probable source of the tsunami of 1 April 1946: Proceedings of the International Tsunami Symposium 2001, NOAA PMEL, p. 683-694.

Fujii, Yushiro, Satake, Kenji, Sakai, Shin'ichi, Shinohara, Masanao, and Kanazawa, Toshihiko, 2011, Tsunami source of the 2011 off the Pacific coast of Tohoku earthquake: Earth Planets Space, v. 63, p. 815-820. doi:10.5047/eps.2011.06.010

Geist. E.L., and Parsons, Tom, 2006, Probabilistic analysis of tsunami hazards: Natural Hazards, v. 37, no. 3, p. 277-314. doi:10.1007/s11069-005-4646-Z

Goto, C., Ogawa, Y., Shuto, N., and Imamura, Fumihiko, 1997, Numerical method of tsunami simulation with the leap-frog scheme: UNESCO, IUGG/IOC TIME Project, Manuals and Guides, no. 35. www.vliz.be/imisdocs/publications/269372. pdf

Hance, J.J., 2003a, Development of a database and assessment of seafloor slope stability based on published literature: Austin, University of Texas at Austin, M.S. Engineering thesis.

Hance, J.J., 2003b, Submarine Slope Stability [based on M.S. Engineering Thesis, "Development of a database and assessment of seafloor slope stability based on published Literature" for University of Texas at Austin by J.J. Hance]: Project report prepared for the Minerals Management Service, MMS Project 421, Offshore Technology Research Center Library Number 8/03B121, $269 \mathrm{p}$.

Hayes, G.P., Wald, D.J., and Johnson, R.L., 2012, Slab1.0-A three-dimensional model of global subduction zone geometries: Journal of Geophysical Research, v. 117, no. B1, 1 p. doi:10.1029/2011JB008524

Johnson, J.M., and Satake, Kenji, 1993, Source parameters of the 1957 Aleutian earthquake from tsunami waveforms: Geophysical Research Letters, v. 20, no. 14, p. 1,487-1,490. doi:10.1029/93GL01217

Johnson, J.M., and Satake, Kenji, 1997, Estimation of seismic moment and slip distribution of the April 1, 1946, Aleutian tsunami earthquake: Journal of Geophysical Research, v. 102, no. B6, p. 11,765-11,774. doi:10.1029/97JB00274

Kanamori, Hiroo, 1970, The Alaska earthquake of 1964-Radiation of long-period surface waves and source mechanism: Journal of Geophysical Research, v. 75, no. 26, p. 5,029-5,040.

Kirby, Stephen, Scholl, David, von Huene, Roland, and Wells, Ray, 2013, Alaska earthquake source for the SAFRR tsunami scenario, chapter B, in Ross, S.L., and Jones, L.M., eds., The SAFRR (Science Application for Risk Reduction) Tsunami Scenario: U.S. Geological Survey Open-File Report 2013-1170, 40 p. http://pubs.usgs.gov/of/2013/1170/b/

Kulikov, E.A., Rabinovich, A.B., Fine, I.V., Bornhold, B.D., and Thomson, R.E., 1998, Tsunami generation by landslides at the Pacific coast of North America and the role of tides: Oceanology, v. 38, no. 3, p. 323-328.

Lander, J.F., 1996, Tsunamis affecting Alaska, 1737-1996: Boulder, CO, National Oceanic and Atmospheric Administration (NOAA), National Geophysical Data Center (NGDC), Key to Geophysical Research Documentation, v. 31, 155 p.

Lastras, Galderic, Amblas, David, Calafat, A.M., Canals, Miquel, Frigola, Jaime, Hermanns, R.L., Lafuerza, Sara, Longva, Oddvar, Micallef, Aaron, Sepúlveda, S.A., Vargas, Gabriel, De Batist, Marc, Van Daele, Maarten, Azpiroz, María, Bascuñán, Ignacio, DuHart, Paul, Iglesias, Olaia, Kempf, Philipp, and Rayo, Xavier, 2013, Landslides cause tsunami waves-Insights from Aysén Fjord, Chile [abst.]: Eos Transactions, American Geophysical Union, v. 94, no. 34, p. 297-298, doi:10.1002/2013EO340002.

Lee, H.J., Schwab, W.C., and Booth J.S., 2002, Submarine landslides-An introduction, in Schwab, W.C., Lee, H.J., and Twichell, D.C., eds., Submarine landslides-Selected studies in the U.S. Exclusive Economic Zone: U.S. Geological Survey Bulletin 2002, p. 1-13. http://dggs.alaska.gov/pubs/id/3760

Lim, E., Eakins, B.W., and Wigley, R., 2011, Coastal relief model of southern Alaska—Procedures, data sources and analysis: National Oceanic and Atmospheric Administration (NOAA) Technical Memorandum NESDIS NGDC-43, 22 p. docs. lib.noaa.gov/noaa_documents/NESDIS/NGDC/TM/NOAA_TM_NESDIS_NGDC_43.pdf

Lisowski, M., Savage, J.C., Prescott, W.H., and Gross, W.K., 1988, Absence of strain accumulation in the Shumagin Seismic Gap, Alaska, 1980-1987: Journal of Geophysical Research, v. 93, no. B7, p. 7,909-7,922. doi:10.1029/JB093iB07p07909.

Lopez, A.M., and Okal, E.A., 2006, A seismological reassessment of the source of the 1946 Aleutian 'tsunami' earthquake: Geophysical Journal International, v. 165, no. 3, p. 835-849. doi:10.1111/j.1365-246X.2006.02899.x

Mather, A.E., Hartley, A.J., and Griffiths, J.S., 2014, The giant coastal landslides of northern Chile-Tectonic and climate interactions on a classic convergent plate margin: Earth and Planetary Science Letters, v. 388, p. 249-256, doi:10.1016/j. epsl.2013.10.019. 
Miller, J.J., von Huene, Roland, and Ryan, H.F., 2014, The 1946 Unimak tsunami earthquake area-Revised tectonic structure in reprocessed seismic images and a suspect near field tsunami source: U.S. Geological Survey Open-File Report 2014-1024, 19 p. doi:10.3133/ofr20141024

Moss, R.E.S., and Travasarou, Thaleia, 2006, Tsunamigenic probabilistic fault displacement hazard analysis for subduction zones-Proceedings of the 8th U.S. National Conference on Earthquake Engineering: Earthquake Engineering Research Institute, Paper 238, 9 p. http://digitalcommons.calpoly.edu/cenv_fac/36

National Geophysical Data Center/World Data Service (NGDC/WDS), in progress, Global historical tsunami database at NGDC, 2100 BC to present (interactive map): National Geophysical Data Center, NOAA. doi:10.7289/V5PN93H7

National Tsunami Hazard Mapping Program (NTHMP), 2010, Guidelines and best practices for tsunami inundation modeling for evacuation planning: National Oceanic and Atmospheric Administration (NOAA), NTHMP Mapping \& Modeling Subcommittee. http://nws.weather.gov/nthmp/mapping_subcommittee.html

2012, Proceedings and results of the 2011 NTHMP Model Benchmarking Workshop: Boulder, CO, U.S. Department of Commerce/NOAA/NTHMP, NOAA Special Report, 436 p. http://nthmp.tsunami.gov

Nicolsky, D.J., 2012, Alaska tsunami model, in Proceedings and Results of the 2011 NTHMP Model Benchmarking Workshop: Boulder, CO, U.S. Department of Commerce/NOAA/NTHMP, NOAA Special Report, p. 55-87, http://nthmp. tsunami.gov

Nicolsky, D.J., Suleimani, E.N., Combellick, R.A., and Hansen, R.A., 2011a, Tsunami inundation maps of Whittier and western Passage Canal, Alaska: Alaska Division of Geological \& Geophysical Surveys Report of Investigation 2011-7, 65 p. doi:10.14509/23244

Nicolsky, D.J., Suleimani, E.N., Haeussler, P.J., Ryan, H.F., Koehler, R.D., Combellick, R.A., and Hansen, R.A., 2013, Tsunami inundation maps of Port Valdez, Alaska: Alaska Division of Geological \& Geophysical Surveys Report of Investigation 2013-1, 77 p., 1 sheet, scale 1:12,500. doi:10.14509/25055

Nicolsky, D.J., Suleimani, E.N., and Hansen, R.A., 2011b, Validation and verification of a numerical model for tsunami propagation and runup: Pure and Applied Geophysics, v. 168, p. 1,199-1,222. doi:10.1007/s00024-010-0231-9

Nicolsky, D.J., Suleimani, E.N., and Koehler, R.D., 2014, Tsunami inundation maps of Cordova and Tatitlek, Alaska: Alaska Division of Geological \& Geophysical Surveys Report of Investigation 2014-1, 49 p. doi:10.14509/27241

Nicolsky, D.J., Suleimani, E.N., Freymueller, J.T. and Koehler, R.D., 2015, Tsunami inundation maps of Fox Islands communities, including Dutch Harbor and Akutan, Alaska: Alaska Division of Geological \& Geophysical Surveys Report of Investigation 2015-5, XX p. doi:10-14509/xxxxxxx.

Nicolsky, D.J., Suleimani, E.N., Freymueller, J.T. and Koehler, R.D., in review, Tsunami inundation maps of the city of Sand Point, Alaska: Alaska Division of Geological \& Geophysical Surveys Report of Investigation.

Nishenko, S.P., 1991, Circum-Pacific seismic potential: 1989-1999, in Okal, Emile A., ed., Aspects of Pacific seismicity: Pure and Applied Geophysics, v. 135, no. 2, p. 169-259.

Okada, Yoshimitsu, 1985, Surface deformation due to shear and tensile faults in a half-space: Bulletin of the Seismological Society of America, v. 75, no. 4, p. 1,135-1,154.

Okal, E.A., Synolakis, C.E., Fryer, G.J., Heinrich, Philippe, Borrero, J.C., Ruscher, Christophe, Arcas, Diego, Guille, Gerard, and Rousseau, Daniel, 2002, A field survey of the 1946 Aleutian tsunami in the far field: Seismological Research Letters, v. 73, no. 4, p. 490-503.

Page, R.A., Biswas, N.N., Lahr, J.C., and Pulpan, Hans, 1991, Seismicity of continental Alaska, in Slemmons, D.B., Engdahl, E.R., Zoback, M.D., and Blackwell, D.D., eds., Neotectonics of North America: Boulder, Colorado, Geological Society of America, Decade Map v. 1, p. 47-68.

Papazachos, B.K., Scordilis, E.M., Panagiotopoulos, D.G., Papazachos, C.B., and Karakaisis, G.F., 2005, Global relations between seismic fault parameters and moment magnitude of earthquakes: Bulletin of the Geological Society of Greece, v. 36, no. 3, p. 1,482-1,489. http://geolib.geo.auth.gr/index.php/bgsg/issue/view/70

Ross, S.L., Jones, L.M., Miller, Kevin, Porter, K.A., Wein, A., Wilson, R.I., Bahng, B., Barberopoulou, A., Borrero, J.C., Brosnan, D.M., Bwarie, J.T., Geist, E.L., Johnson, L.A., Kirby, S.H., Knight, W.R., Long, K., Lynett, P., Mortensen, C.E., Nicolsky, D.J., Perry, S.C., Plumlee, G.S., Real, C.R., Ryan, K., Suleimani, E.N., Thio, H.K., Titov, V.V., Whitmore, P.M. and Wood, N.J., 2013, SAFRR (Science Application for Risk Reduction) Tsunami Scenario-Chapter A, Executive Summary and Introduction, in Ross, S.L., and Jones, L.M., eds., The SAFRR Tsunami Scenario: U.S. Geological Survey Open-File Report 2013-1170, p. 1-17.

Ryan, Holly, von Huene, Roland, Scholl, Dave, and Kirby, Steve, 2012, Tsunami hazards to U.S. coasts from giant earthquakes in Alaska: Eos Transactions, American Geophysical Union, v. 93, no. 19, p. 185-186.

Shao, Guangfu, Li, Xiangyu, Ji, Chen, and Maeda, Takahiro, 2011, Focal mechanism and slip history of $2011 \mathrm{M}_{\mathrm{W}} 9.1$ off the Pacific coast of Tohoku earthquake, constrained with teleseismic body and surface waves: Earth, Planets and Space, v. 63, no. 7, p. 559-564., doi:10.5047/eps.2011.06.028

Stein, Seth, and Okal, E.A., 2007, Ultralong period seismic study of the December 2004 Indian Ocean earthquake and implications for regional tectonics and the subduction process: Bulletin of the Seismological Society of America, v. 97, no. 1A, p. S279-S295. doi:10.1785/0120050617 
Suleimani, E.N., Nicolsky, D.J., West, D.A., Combellick, R.A., and Hansen, R.A., 2010, Tsunami inundation maps of Seward and northern Resurrection Bay, Alaska: Alaska Division of Geological \& Geophysical Surveys Report of Investigation 2010-1, 47 p., 3 sheets, scale 1:12,500, doi:10.14509/21001

Suleimani, E.N., Nicolsky, D.J., and Koehler, R.D., 2013, Tsunami inundation maps of Sitka, Alaska: Alaska Division of Geological \& Geophysical Surveys Report of Investigation 2013-3, 76 p., 1 sheet, scale 1:250,000, doi:10.14509/26671

Suleimani, E.N., Nicolsky, D.J., and Koehler, R.D., 2015, Tsunami inundation maps of Elfin Cove, Gustavus, and Hoonah, Alaska: Alaska Division of Geological \& Geophysical Surveys Report of Investigation 2015-1, 79 p. doi:10.14509/29404

Sykes, L.R., 1971, Aftershock zones of great earthquakes, seismicity gaps, and earthquake prediction for Alaska and the Aleutians: Journal of Geophysical Research, v. 76, no. 32, p. 8,021-8,041.

Synolakis, C.E., Bernard, E.N., Titov, V.V., Kânoğlu, U., and González, F.I., 2007, Standards, criteria, and procedures for NOAA evaluation of tsunami numerical models: Seattle, WA, NOAA/Pacific Marine Environmental Laboratory, Technical Memorandum OAR PMEL-135, 55 p. http://www.pmel.noaa.gov/pubs/PDF/syno3053/syno3053.pdf

Tanioka, Yuichiro, Satake, Kenji, Ruff, Larry, and Gonzales, Frank, 1994, Fault parameters and tsunami excitation of the May 13, 1993, Shumagin Islands earthquake: Geophysical Research Letters, v. 21, no. 11, p. 967-970. doi:10.1029/94GL00875

Tang, Liujuan, Titov, V.V., Bernard, E.N., Wei, Yong, Chamberlain, C.D., Newman, J.C., Mofjeld, H.O., Arcas, Diego, Eble, M.C., Moore, Christopher, Uslu, Burak, Pells, Clint, Spillane, Michael, Wright, Lindsey, and Gica, Edison, 2012, Direct energy estimation of the 2011 Japan tsunami using deep-ocean pressure measurements: Journal of Geophysical Research-Oceans, v. 117, no. C8, p. 8. doi:10.1029/2011JC007635

Tichelaar, B.W., and Ruff, L.J., 1993, Depth of seismic coupling along subduction zones: Journal of Geophysical Research, v. 98, no. B2, p. 2,017-2,037. doi:10.1029/92JB02045

von Huene, Roland, Kirby, Stephen, Miller, John, and Dartnell, Peter, 2014, The destructive 1946 Unimak near-field tsunami-New evidence for a submarine slide source from reprocessed marine geophysical data: Geophysical Research Letters, v. 41, no. 19, p. 6,811-6,818. doi:10.1002/2014GL061759

Wesson, R.L., Boyd, O.S., Mueller, C.S., Bufe, C.G., Frankel, A.D., and Petersen, M.D., 2007, Revision of time-independent probabilistic seismic hazard maps for Alaska: U.S. Geological Survey Open-File Report 2007-1043, 33 p. http://pubs. usgs.gov/of/2007/1043/

Wesson, R.L., Boyd, O.S., Mueller, C.S., and Frankel, A.D., 2008, Challenges in making a seismic hazard map for Alaska and the Aleutians, in Freymueller, J.T., Haeussler, P.J., Wesson, R., and Ekström, G., eds., Active tectonics and seismic potential of Alaska: Washington, DC, American Geophysical Union, Geophysical Monograph v. 179, p. 385-397. doi:10.1029/GM179

Witter, R.C., Briggs, R.W., Engelhart, S.E., Gelfenbaum, G., Koehler, R.D., and Barnhart, W.D., 2014, Little late Holocene strain accumulation and release on the Aleutian megathrust below the Shumagin Islands, Alaska: Geophysical Research Letters, v. 41, no. 7, p. 2,359-2,367. doi:10.1002/2014GL059393

Wu, F.T., and Kanamori, Hiroo, 1973, Source mechanism of February 4, 1965, Rat Island earthquake: Journal of Geophysical Research, v. 78, no. 26, p. 6,082-6,092. doi:10.1029/JB078i026p06082 


\section{APPENDIX A} KING COVE

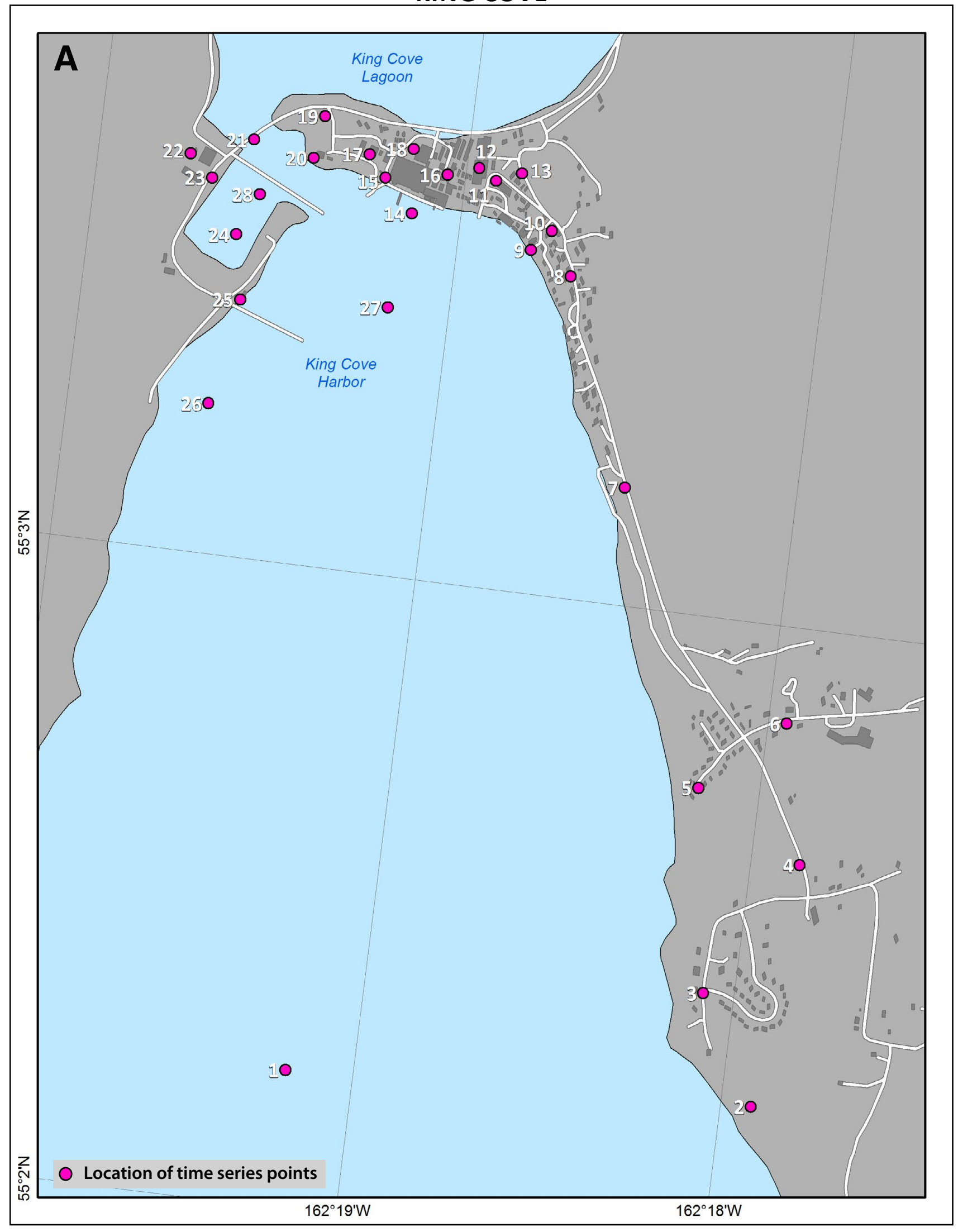

Figure A-1. Maps showing locations of time series points in King Cove Harbor (A) and in the part of the King Cove community located between King Cove Harbor and King Cove Lagoon (B). The latitude and longitude locations for time series points are listed in table A-1. 


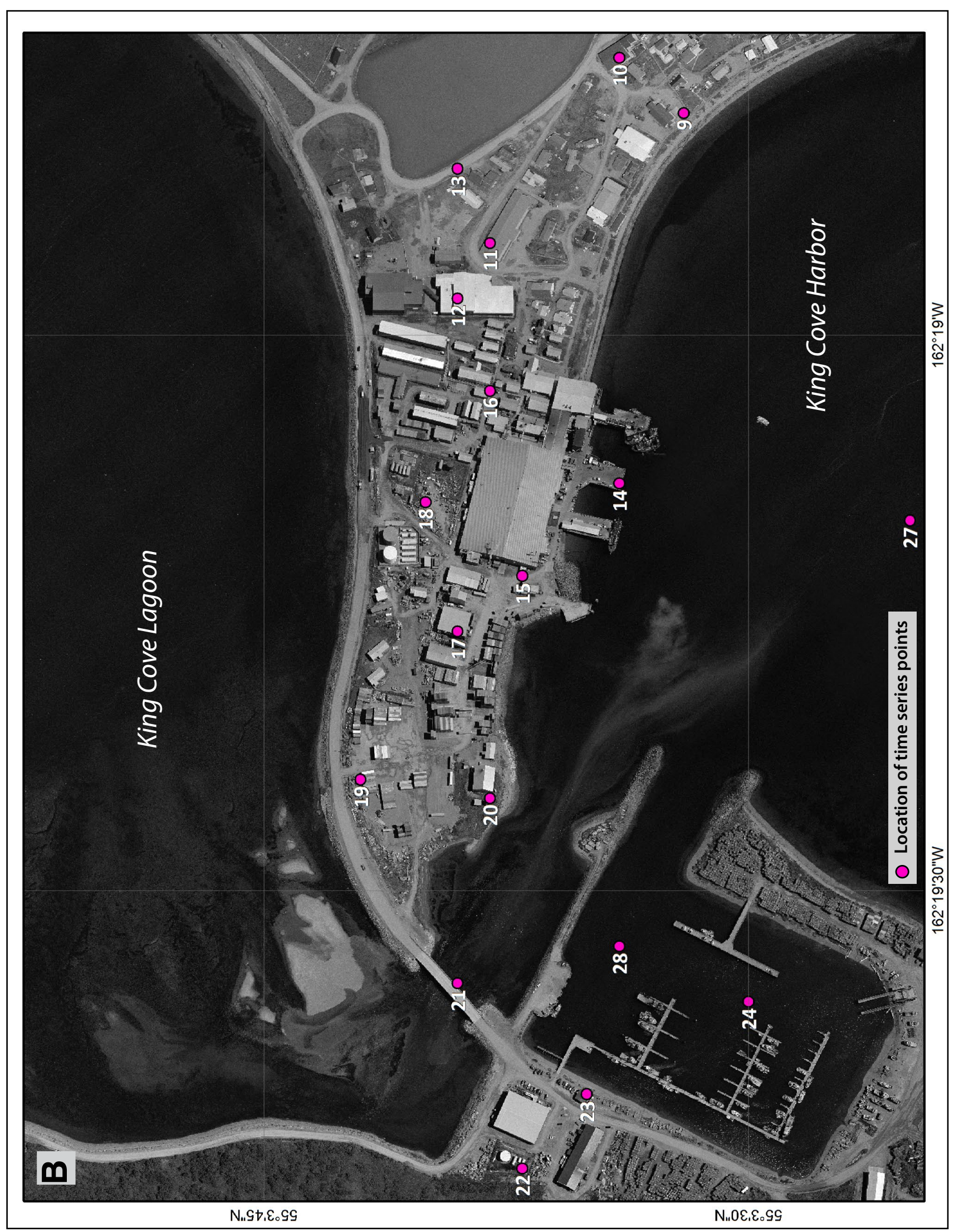

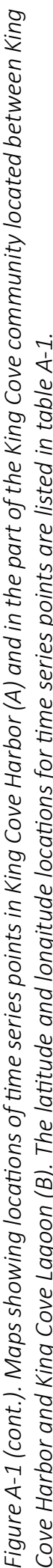




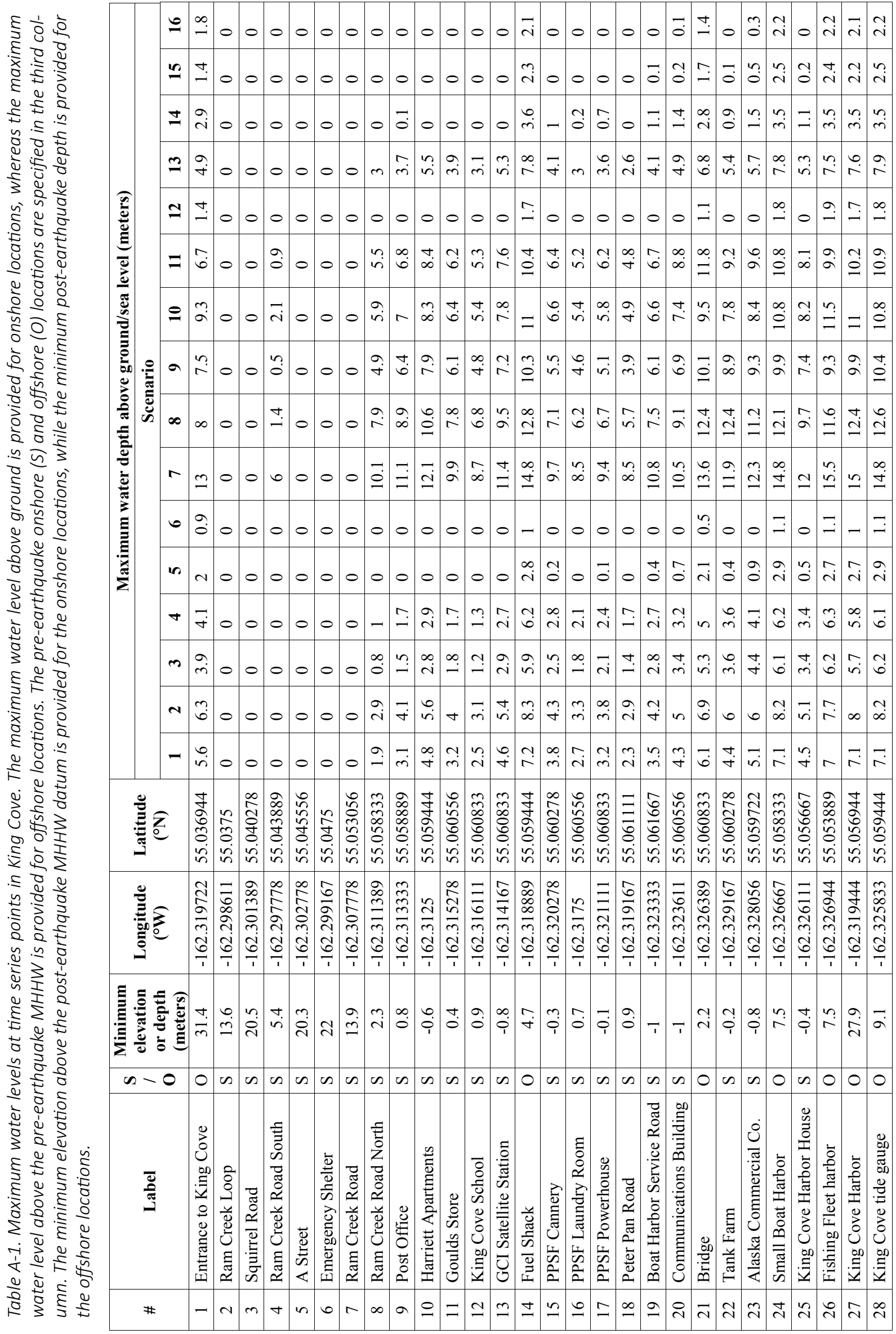




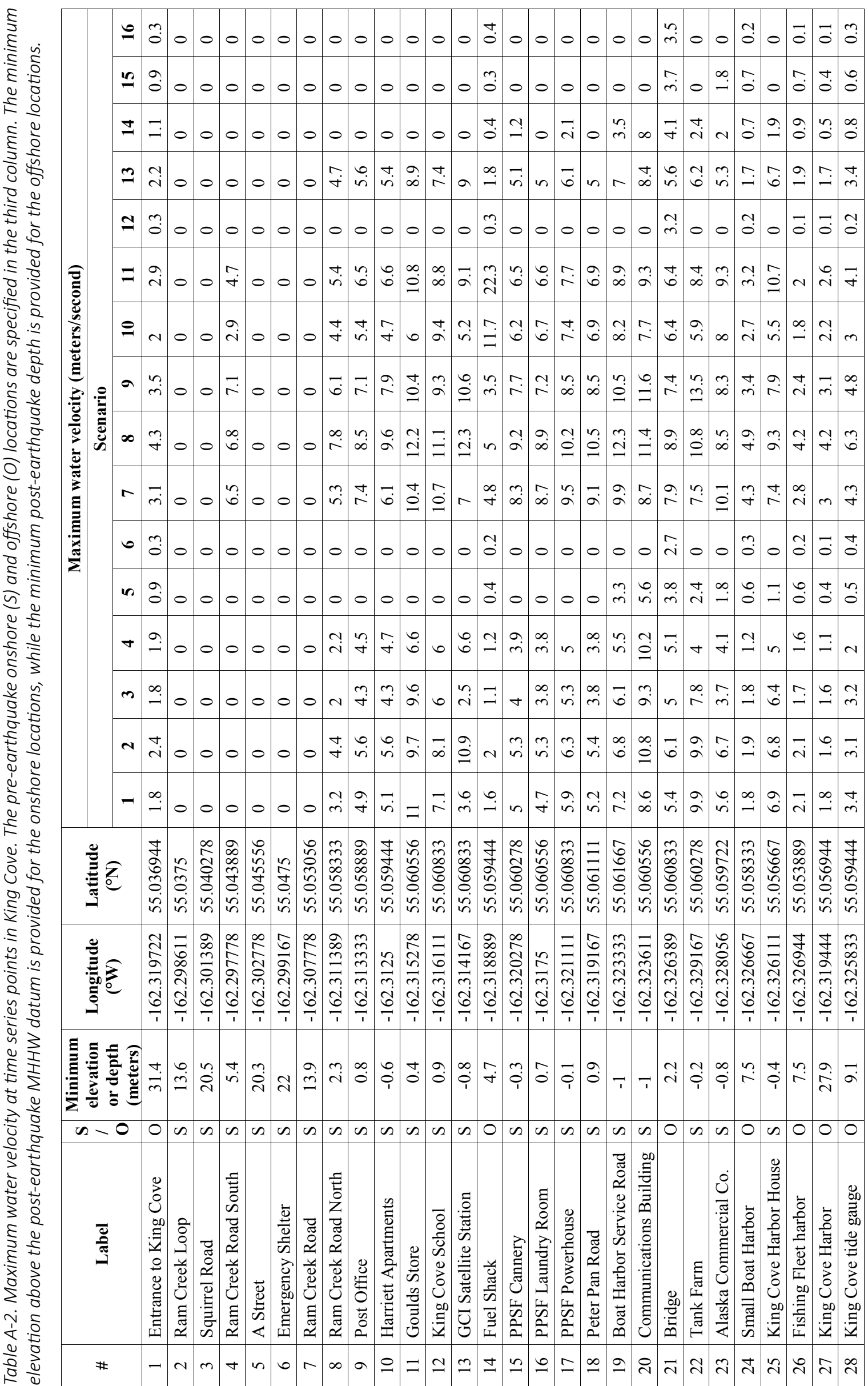




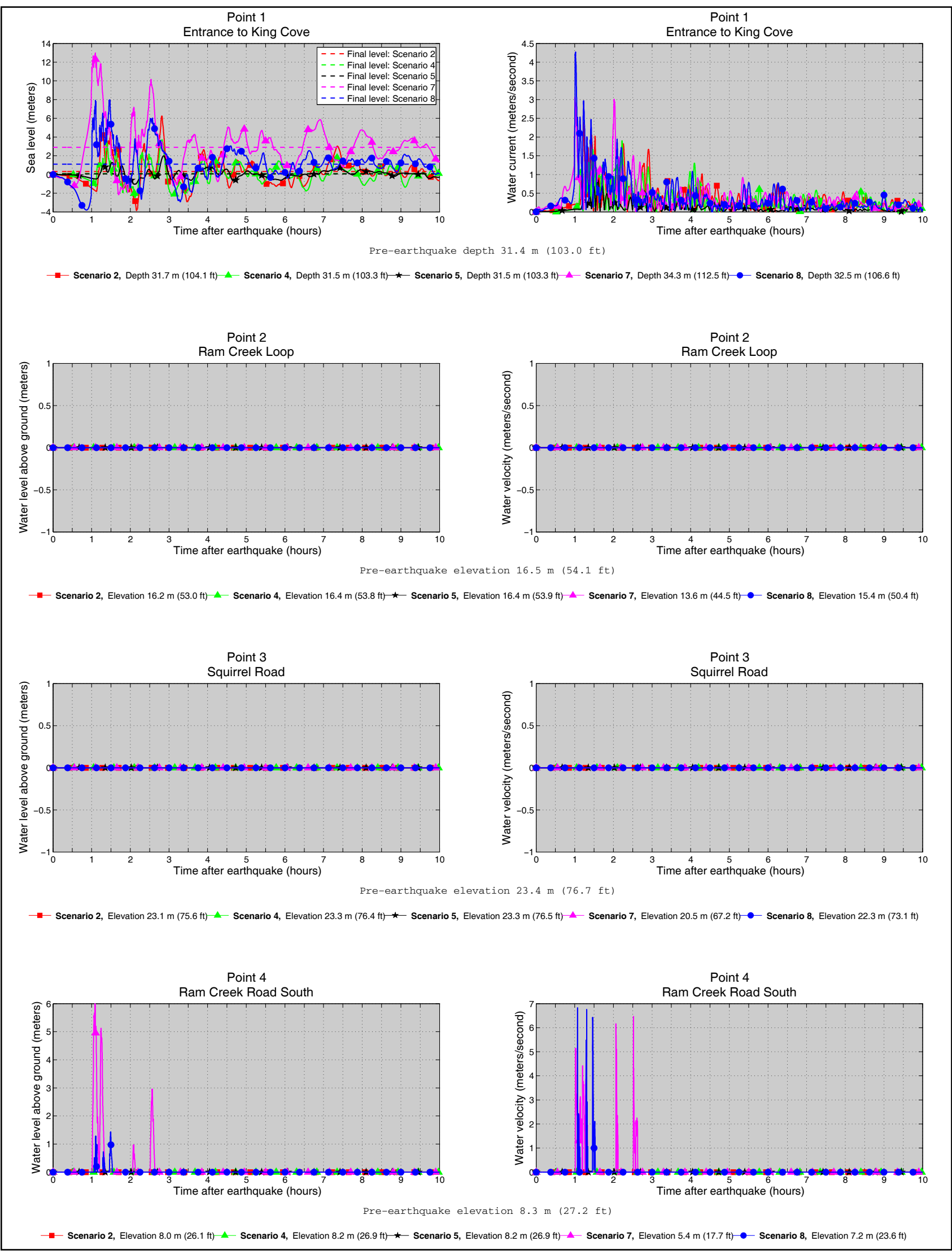

Figure A-2. Graphs showing time series of water level (left column) and velocity (right column) for selected locations in King Cove for scenarios 2, 4, 5, 7, and 8. For each location, pre-earthquake and post-earthquake elevation/depth corresponding to the MHHW datum is provided for each scenario. For some onshore locations, the post-earthquake value could be referenced as "depth" for some scenarios, and as "elevation" for others, indicating that different scenarios resulted in different amount of coseismic subsidence. For offshore locations, to show the height of an arriving tsunami, the vertical datum is such that zero corresponds to the pre-earthquake sea level. Dashed lines indicate the final water level after the tsunami. 

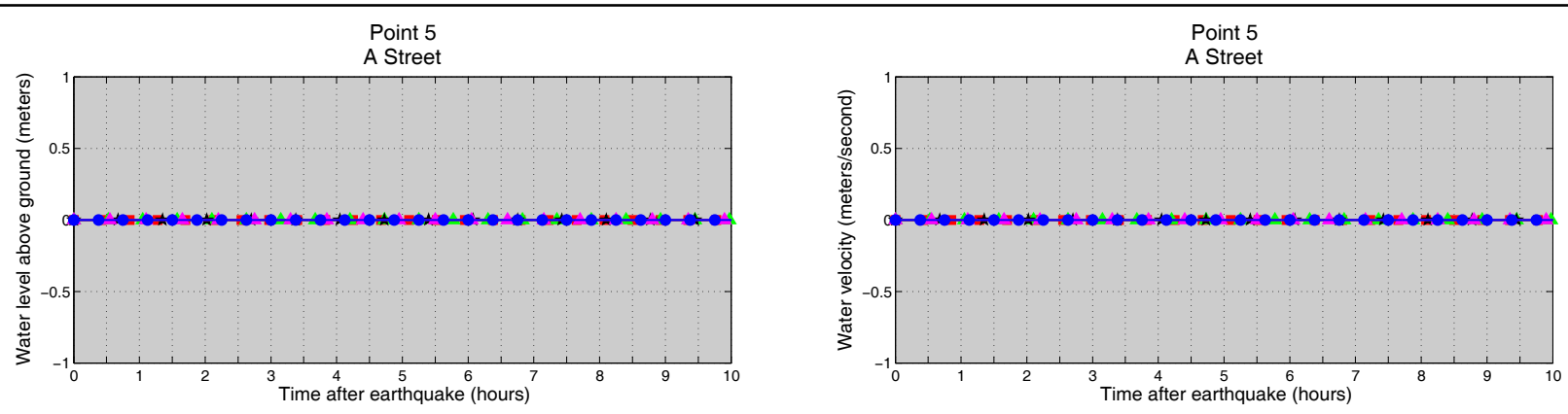

Pre-earthquake elevation $23.1 \mathrm{~m}(75.9 \mathrm{ft})$

- Scenario 2, Elevation $22.8 \mathrm{~m}(74.8 \mathrm{ft}) \_$Scenario 4, Elevation $23.1 \mathrm{~m}(75.6 \mathrm{ft}) \star$ - Scenario 5, Elevation $23.1 \mathrm{~m}(75.6 \mathrm{ft})-$ Scenario 7 , Elevation $20.3 \mathrm{~m}(66.4 \mathrm{ft})-$ Scenario 8 , Elevation $22.1 \mathrm{~m}(72.3 \mathrm{ft})$
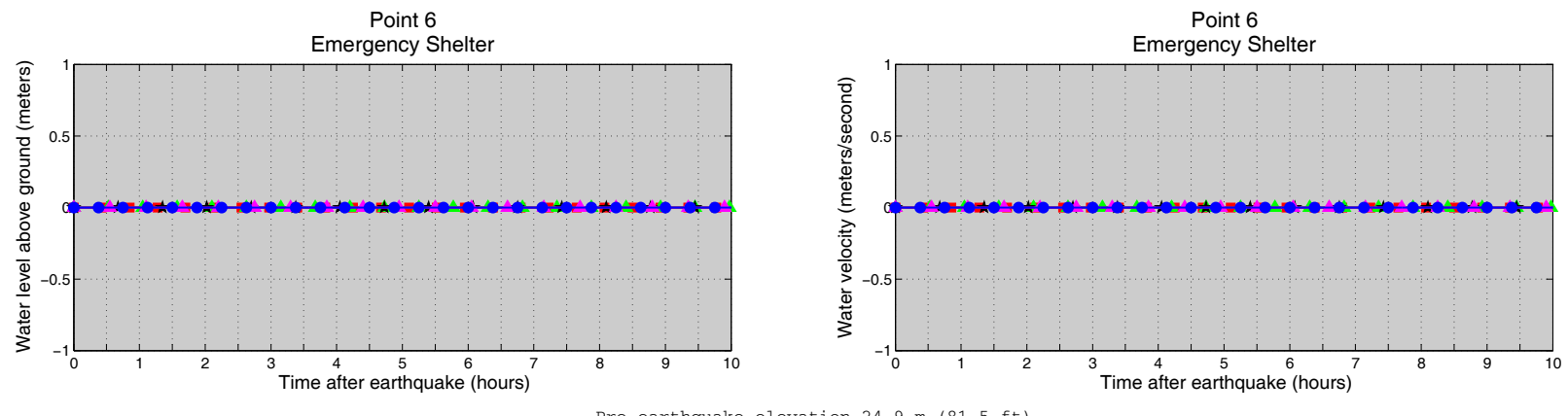

- Scenario 2, Elevation $24.5 \mathrm{~m}(80.4 \mathrm{ft})-$ Scenario 4, Elevation $24.8 \mathrm{~m}(81.2 \mathrm{ft}) \star$ Scenario 5 , Elevation $24.8 \mathrm{~m}(81.3 \mathrm{ft})-$ Scenario 7 , Elevation $22.0 \mathrm{~m}(72.1 \mathrm{ft})-$ Scenario 8 , Elevation $23.8 \mathrm{~m}(77.9 \mathrm{ft})$
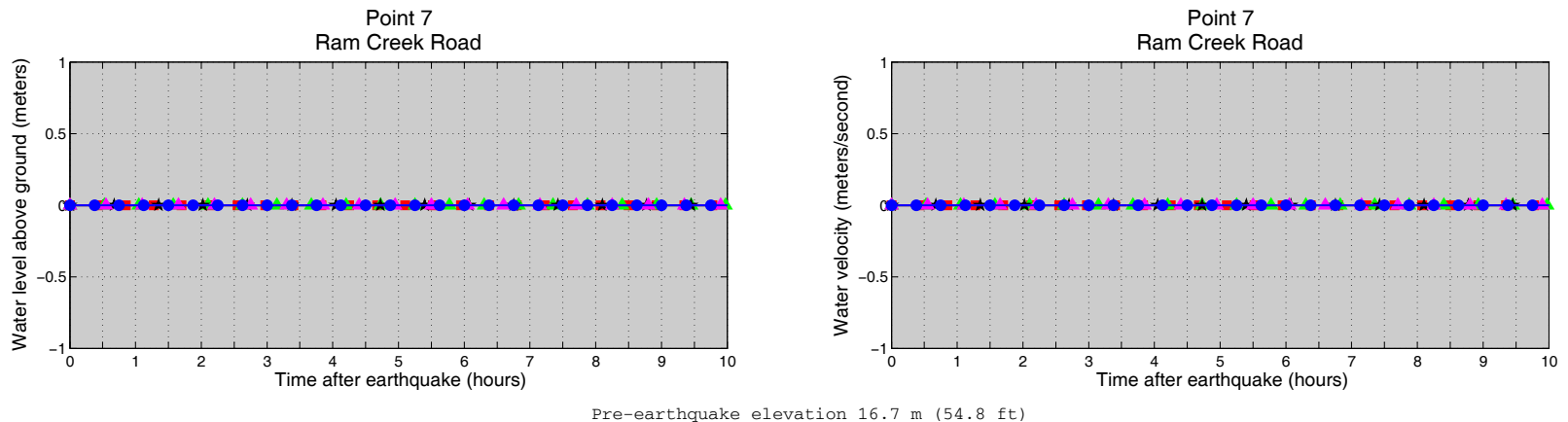

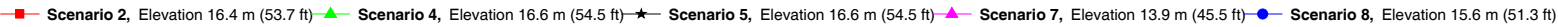

Point 8

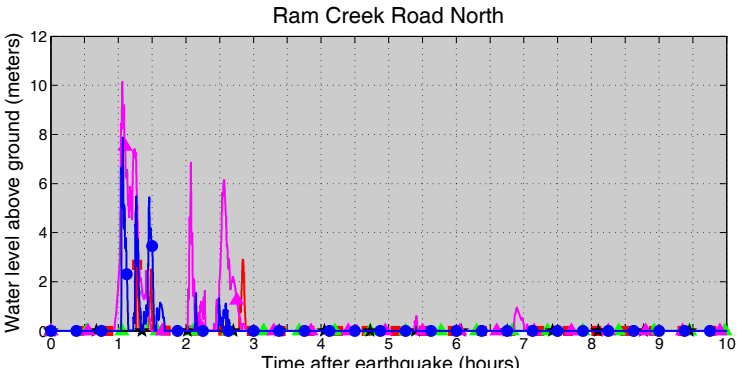

Pre-earthquake elevation $5.1 \mathrm{~m}(16.6 \mathrm{ft}$
Point 8

Ram Creek Road North

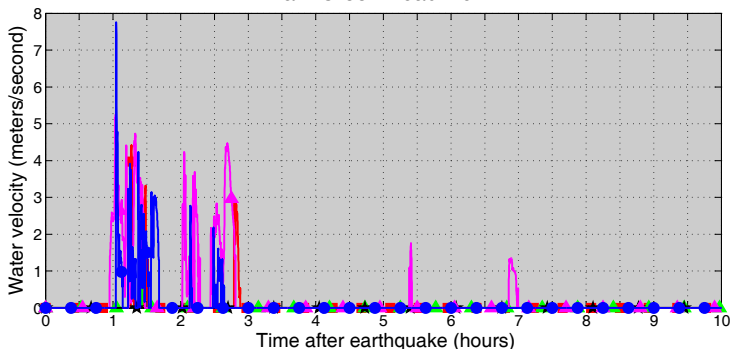

Time after earthquake (hours)

- Scenario 2, Elevation $4.7 \mathrm{~m}(15.5 \mathrm{ft}) \backsim$ Scenario 4, Elevation $5.0 \mathrm{~m}(16.3 \mathrm{ft}) \star$ - Scenario 5 , Elevation $5.0 \mathrm{~m}(16.4 \mathrm{ft}) \backsim$ Scenario 7 , Elevation $2.3 \mathrm{~m}(7.4 \mathrm{ft}) \longrightarrow-$ Scenario 8 , Elevation $4.0 \mathrm{~m}(13.2 \mathrm{ft})$

Figure A-2 (cont.). Graphs showing time series of water level (left column) and velocity (right column) for selected locations in King Cove for scenarios 2, 4, 5, 7, and 8. For each location, pre-earthquake and post-earthquake elevation/depth corresponding to the MHHW datum is provided for each scenario. For some onshore locations, the post-earthquake value could be referenced as "depth" for some scenarios, and as "elevation" for others, indicating that different scenarios resulted in different amount of coseismic subsidence. For offshore locations, to show the height of an arriving tsunami, the vertical datum is such that zero corresponds to the pre-earthquake sea level. Dashed lines indicate the final water level after the tsunami. 

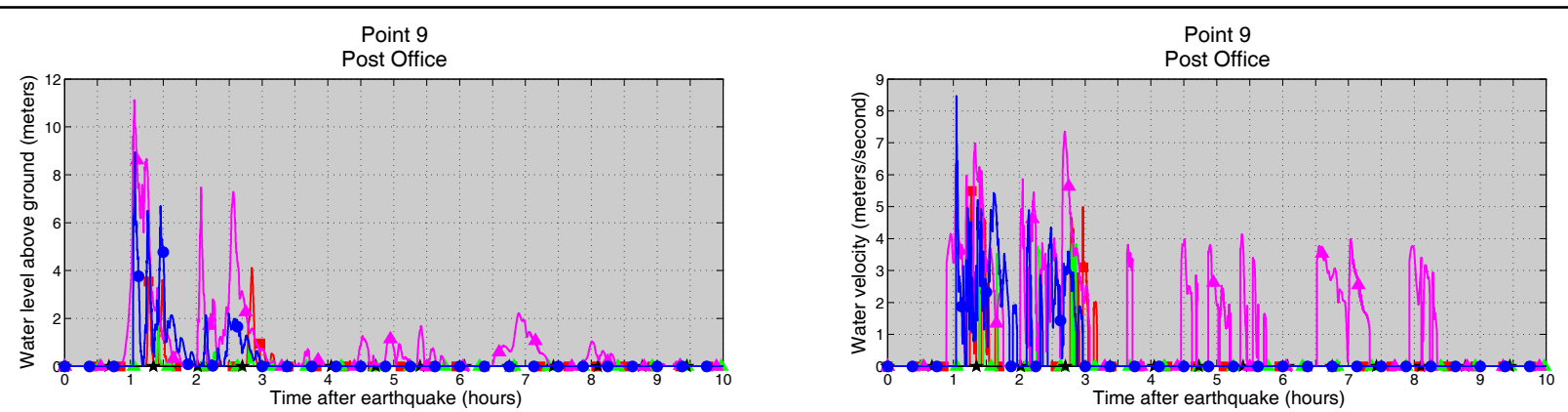

Pre-earthquake elevation $3.6 \mathrm{~m}(11.8 \mathrm{ft})$

— Scenario 2, Elevation $3.3 \mathrm{~m}(10.8 \mathrm{ft}) \_$Scenario 4, Elevation $3.5 \mathrm{~m}(11.5 \mathrm{ft}) \_$Scenario 5 , Elevation $3.5 \mathrm{~m}(11.6 \mathrm{ft}) \_$Scenario 7 , Elevation $0.8 \mathrm{~m}(2.7 \mathrm{ft}) \multimap-$ Scenario 8 , Elevation $2.6 \mathrm{~m}(8.4 \mathrm{ft})$
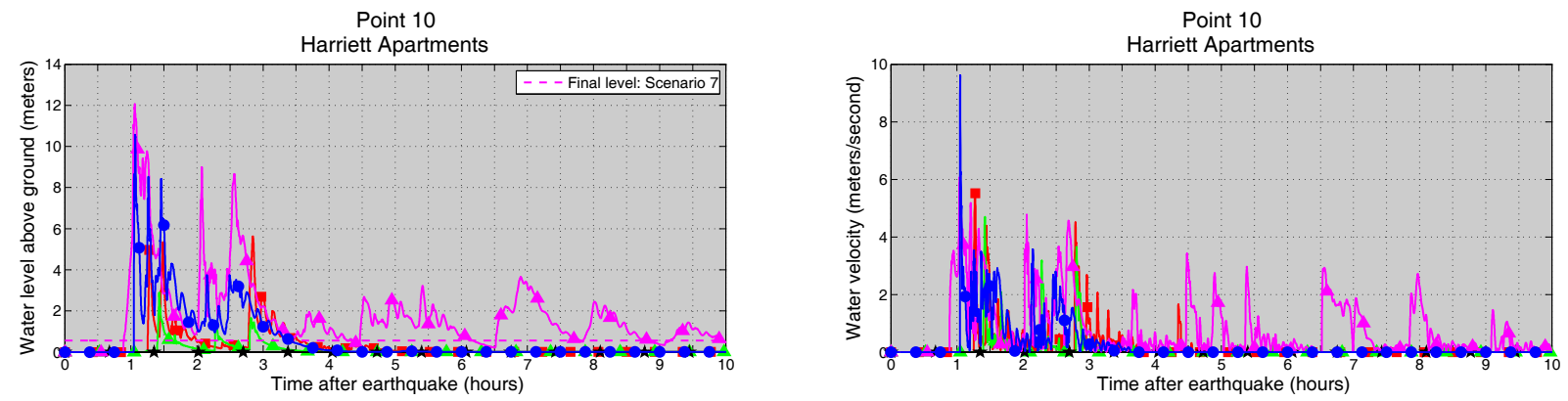

Pre-earthquake elevation $2.2 \mathrm{~m}(7.3 \mathrm{ft})$

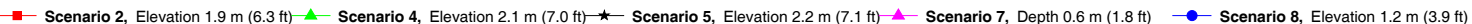
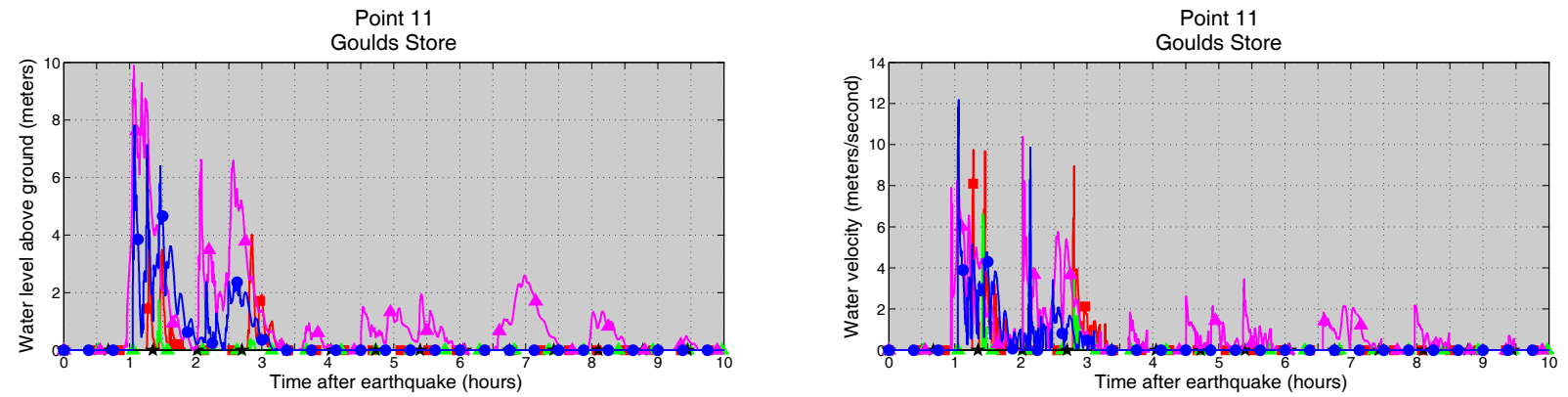

Pre-earthquake elevation $3.1 \mathrm{~m}(10.3 \mathrm{ft})$

- Scenario 2, Elevation $2.8 \mathrm{~m}(9.2 \mathrm{ft})-$ Scenario 4, Elevation $3.0 \mathrm{~m}(10.0 \mathrm{ft}) \star$ - Scenario 5 , Elevation $3.1 \mathrm{~m}(10.0 \mathrm{ft}) \backsim$ Scenario 7 , Elevation $0.4 \mathrm{~m}(1.2 \mathrm{ft}) \rightarrow-$ Scenario 8 , Elevation $2.1 \mathrm{~m}(6.9 \mathrm{ft})$
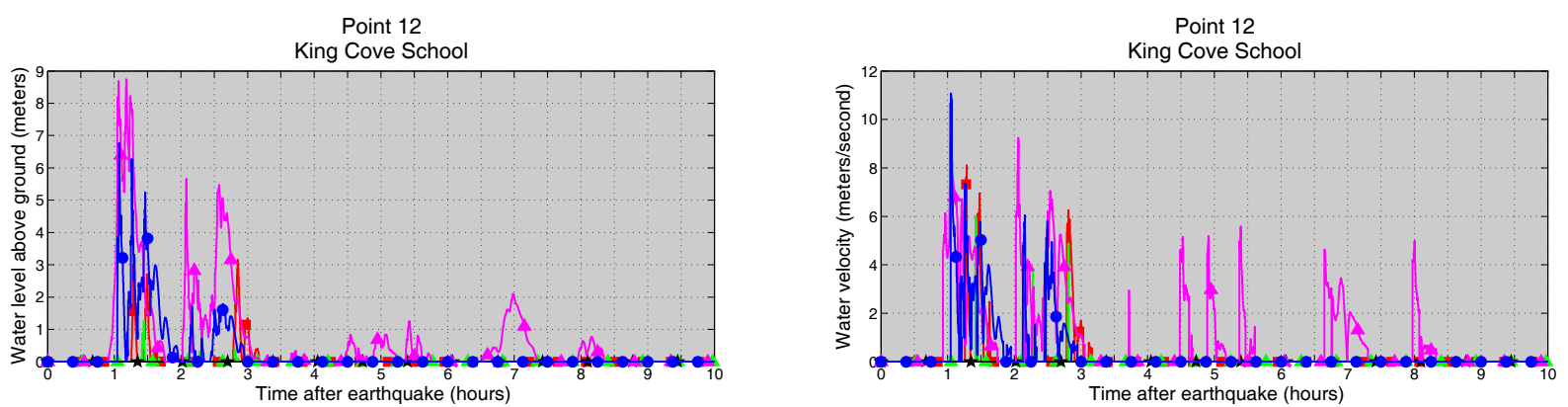

Pre-earthquake elevation $3.7 \mathrm{~m}(12.0 \mathrm{ft})$

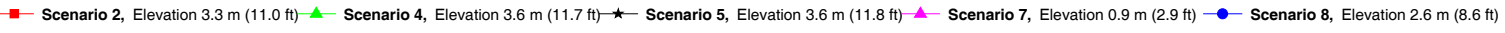

Figure A-2 (cont.). Graphs showing time series of water level (left column) and velocity (right column) for selected locations in King Cove for scenarios 2, 4, 5, 7, and 8. For each location, pre-earthquake and post-earthquake elevation/depth corresponding to the MHHW datum is provided for each scenario. For some onshore locations, the post-earthquake value could be referenced as "depth" for some scenarios, and as "elevation" for others, indicating that different scenarios resulted in different amount of coseismic subsidence. For offshore locations, to show the height of an arriving tsunami, the vertical datum is such that zero corresponds to the pre-earthquake sea level. Dashed lines indicate the final water level after the tsunami. 

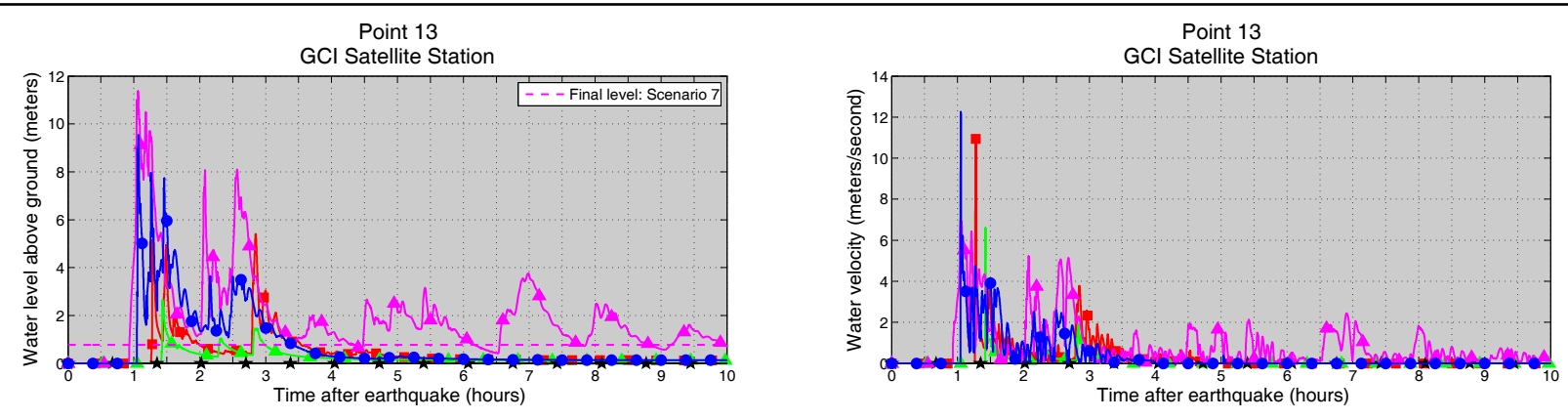

Pre-earthquake elevation $2.0 \mathrm{~m}(6.6 \mathrm{ft})$

- Scenario 2, Elevation $1.7 \mathrm{~m}(5.5 \mathrm{ft})-$ Scenario 4, Elevation $1.9 \mathrm{~m}(6.3 \mathrm{ft}) \star$ - Scenario 5, Elevation $1.9 \mathrm{~m}(6.3 \mathrm{ft})-$ Scenario 7 , Depth $0.8 \mathrm{~m}(2.5 \mathrm{ft}) \longrightarrow-$ Scenario 8 , Elevation $1.0 \mathrm{~m}(3.2 \mathrm{ft})$
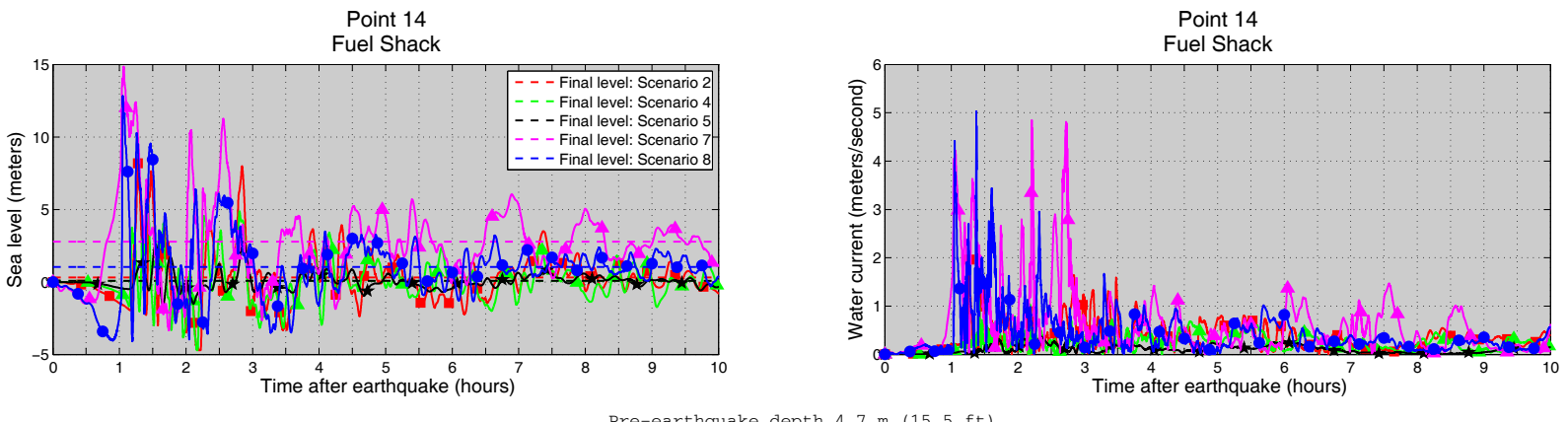

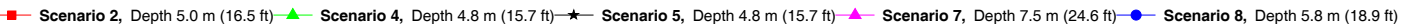
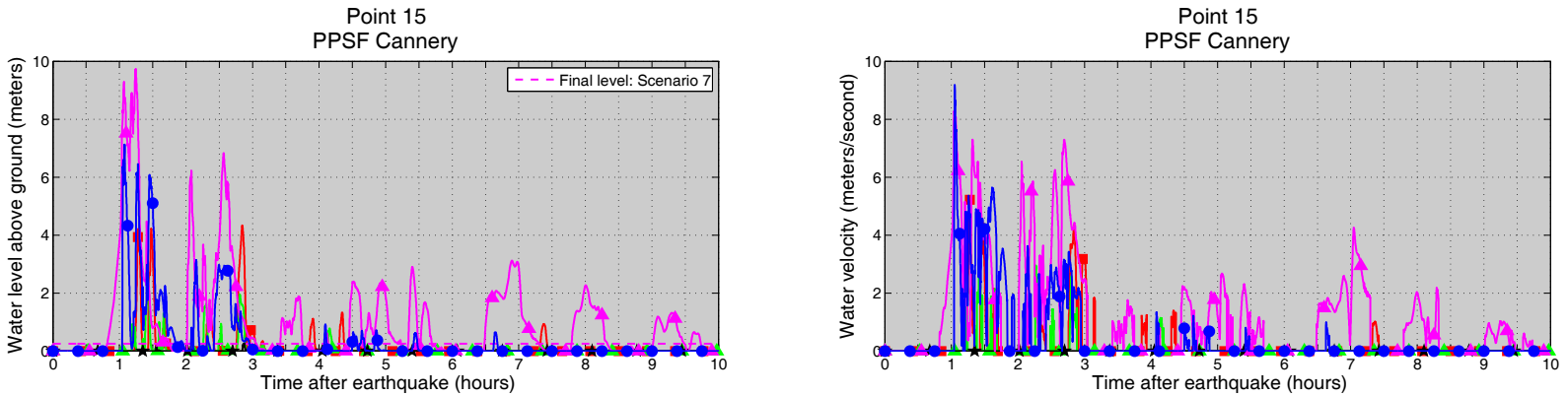

Pre-earthquake elevation $2.5 \mathrm{~m}(8.2 \mathrm{ft}$

- Scenario 2, Elevation $2.2 \mathrm{~m}(7.2 \mathrm{ft})-$ Scenario 4, Elevation $2.4 \mathrm{~m}(8.0 \mathrm{ft})-$ « Scenario 5 , Elevation $2.4 \mathrm{~m}(8.0 \mathrm{ft})-$ Scenario 7 , Depth $0.3 \mathrm{~m}(0.8 \mathrm{ft})-\bullet$ Scenario 8 , Elevation $1.5 \mathrm{~m}(4.8 \mathrm{ft})$

Point 16

PPSF Laundry Room

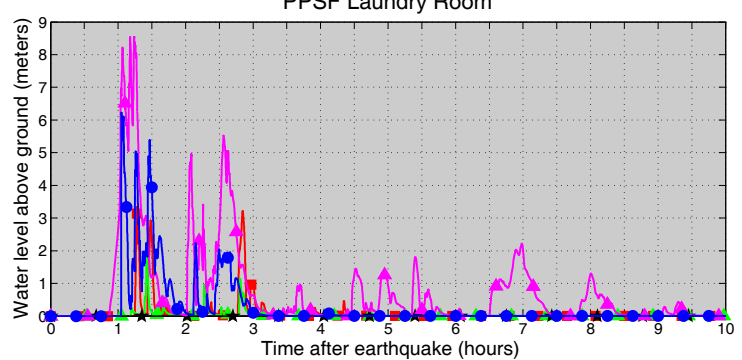

Point 16

PPSF Laundry Room

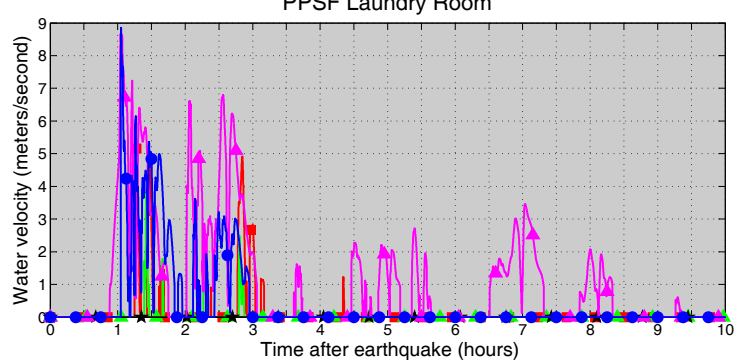

Time after earthquake (hours)

- Scenario 2, Elevation $3.2 \mathrm{~m}(10.3 \mathrm{ft}) \leadsto$ Scenario 4, Elevation $3.4 \mathrm{~m}(11.1 \mathrm{ft}) \star$ Scenario 5, Elevation $3.4 \mathrm{~m}(11.1 \mathrm{ft}) \backsim$ Scenario 7 , Elevation $0.7 \mathrm{~m}(2.3 \mathrm{ft})-\bullet$ Scenario 8 , Elevation $2.4 \mathrm{~m}(8.0 \mathrm{ft})$

Figure A-2 (cont.). Graphs showing time series of water level (left column) and velocity (right column) for selected locations in King Cove for scenarios 2, 4, 5, 7, and 8. For each location, pre-earthquake and post-earthquake elevation/depth corresponding to the MHHW datum is provided for each scenario. For some onshore locations, the post-earthquake value could be referenced as "depth" for some scenarios, and as "elevation" for others, indicating that different scenarios resulted in different amount of coseismic subsidence. For offshore locations, to show the height of an arriving tsunami, the vertical datum is such that zero corresponds to the pre-earthquake sea level. Dashed lines indicate the final water level after the tsunami. 

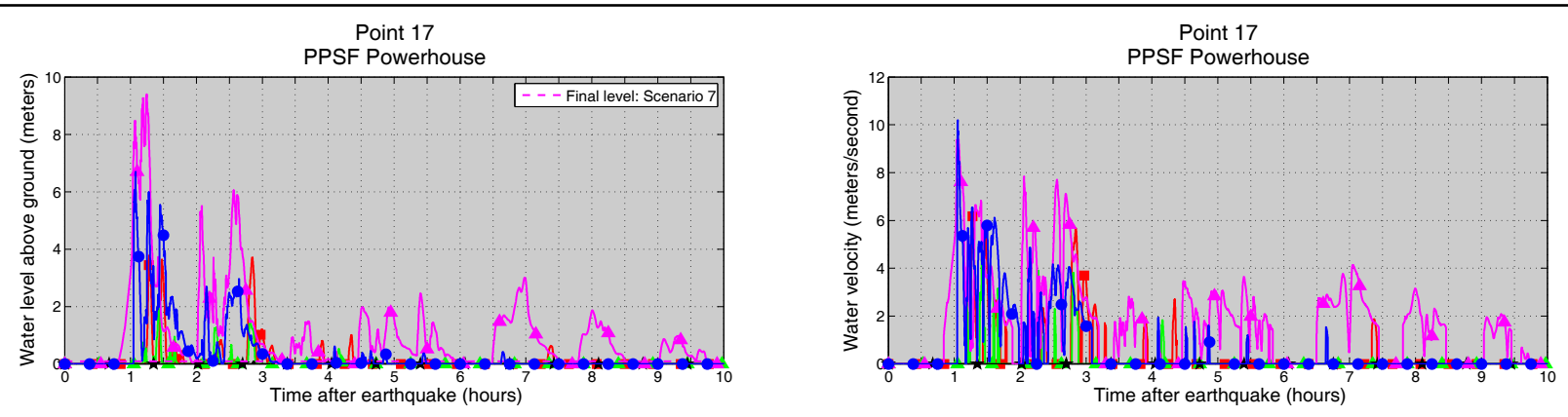

- Scenario 2, Elevation $2.4 \mathrm{~m}(7.7 \mathrm{ft}) \simeq$ Scenario 4, Elevation $2.6 \mathrm{~m}(8.5 \mathrm{ft}) \multimap$ Scenario 5 , Elevation $2.6 \mathrm{~m}(8.5 \mathrm{ft}) \_$Scenario 7 , Depth $0.1 \mathrm{~m}(0.3 \mathrm{ft})$

- Scenario 8, Elevation $1.6 \mathrm{~m}(5.4 \mathrm{ft})$
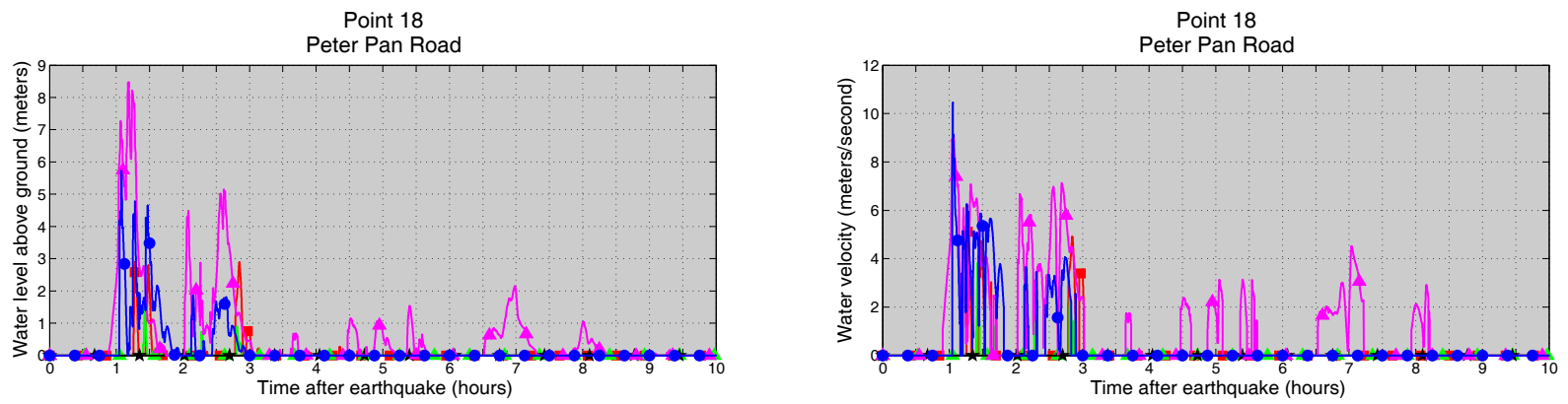

- Scenario 2, Elevation $3.3 \mathrm{~m}(10.9 \mathrm{ft}) \_$Scenario 4, Elevation $3.6 \mathrm{~m}(11.7 \mathrm{ft}) \star$ « Scenario 5, Elevation $3.6 \mathrm{~m}(11.7 \mathrm{ft}) \_$Scenario 7 , Elevation $0.9 \mathrm{~m}(2.9 \mathrm{ft}) \rightarrow-$ Scenario 8 , Elevation $2.6 \mathrm{~m}(8.6 \mathrm{ft})$

Point 19

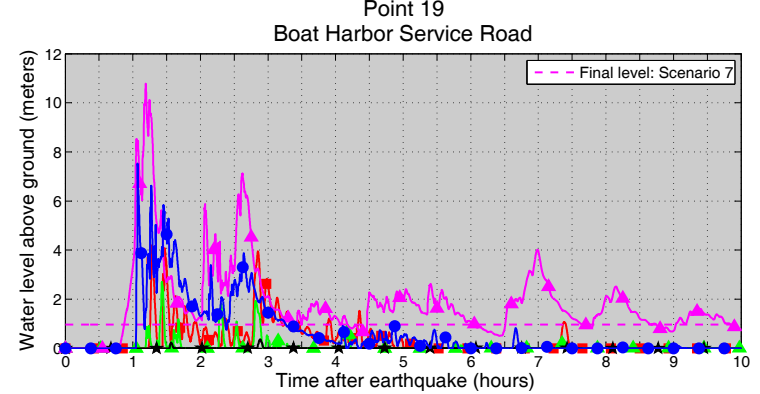

Pre-earthquake elevation $1.8 \mathrm{~m}(5.8 \mathrm{ft})$
Point 19

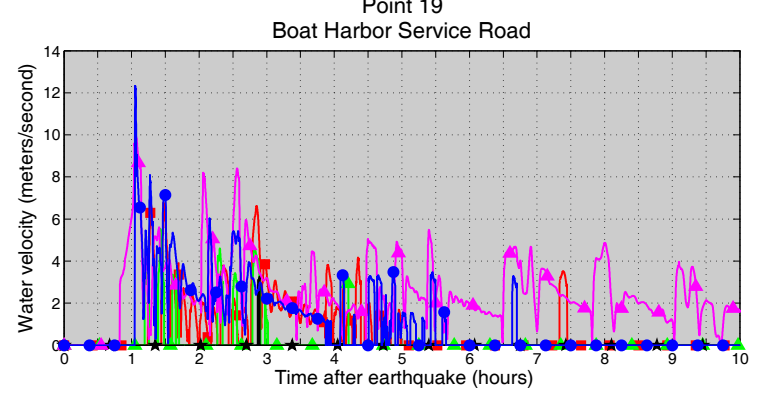

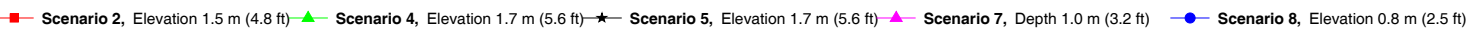

Point 20

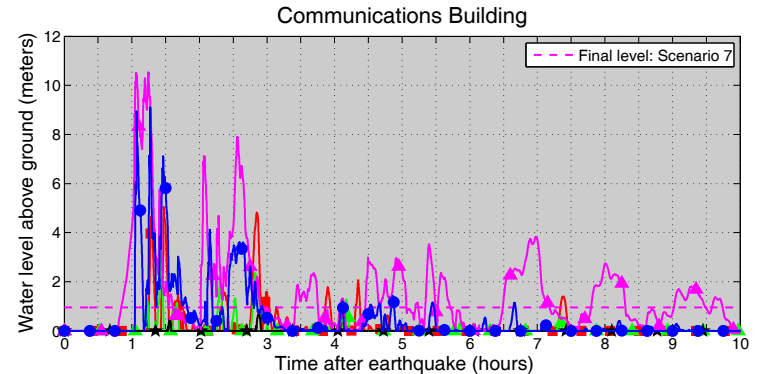

Point 20

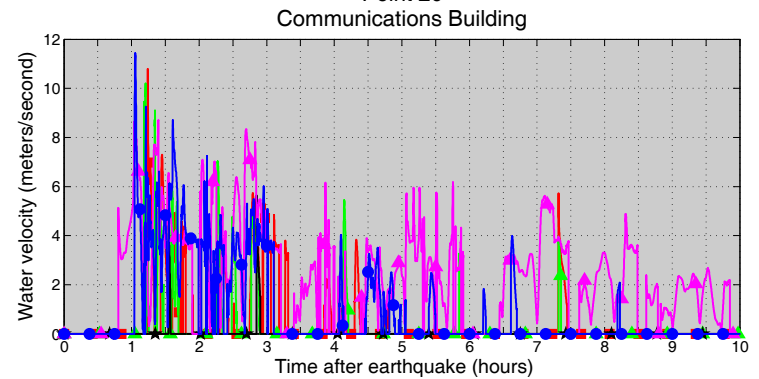

Pre-earthquake elevation $1.8 \mathrm{~m}(5.9 \mathrm{ft})$

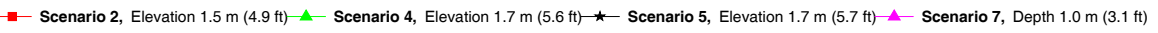

Scenario 8, Elevation $0.8 \mathrm{~m}(2.5 \mathrm{ft})$

Figure A-2 (cont.). Graphs showing time series of water level (left column) and velocity (right column) for selected locations in King Cove for scenarios 2, 4, 5, 7, and 8. For each location, pre-earthquake and post-earthquake elevation/depth corresponding to the MHHW datum is provided for each scenario. For some onshore locations, the post-earthquake value could be referenced as "depth" for some scenarios, and as "elevation" for others, indicating that different scenarios resulted in different amount of coseismic subsidence. For offshore locations, to show the height of an arriving tsunami, the vertical datum is such that zero corresponds to the pre-earthquake sea level. Dashed lines indicate the final water level after the tsunami. 

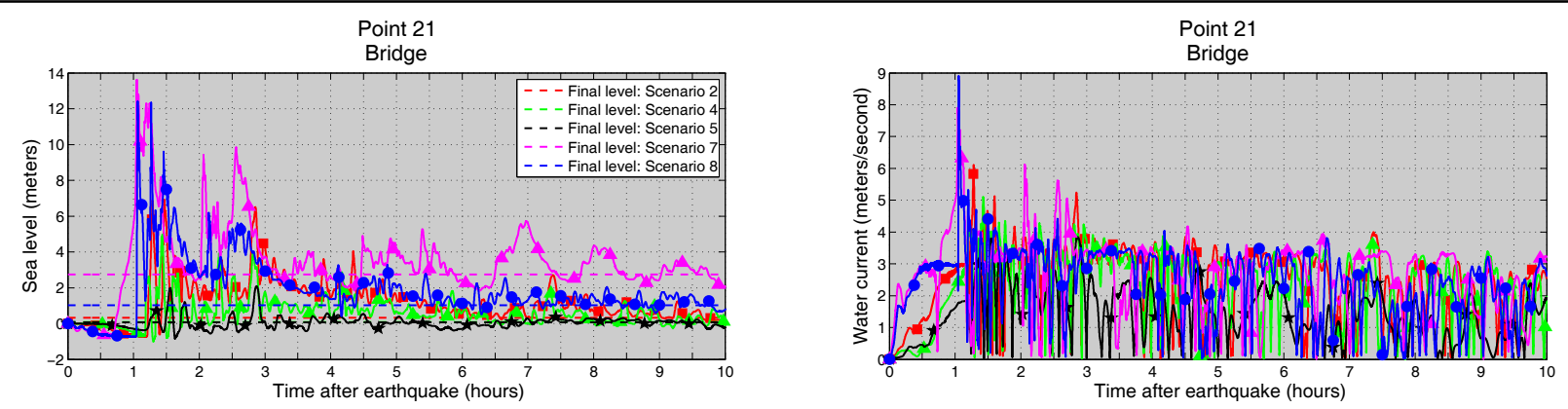

Pre-earthquake depth $2.2 \mathrm{~m}(7.1 \mathrm{ft})$

- Scenario 2, Depth $2.5 \mathrm{~m}(8.1 \mathrm{ft})-$ Scenario 4, Depth $2.2 \mathrm{~m}(7.4 \mathrm{ft}) \multimap$ Scenario 5, Depth $2.2 \mathrm{~m}(7.3 \mathrm{ft})-$ Scenario 7 , Depth $4.9 \mathrm{~m}(16.1 \mathrm{ft})-$ Scenario 8 , Depth $3.2 \mathrm{~m}(10.4 \mathrm{ft})$
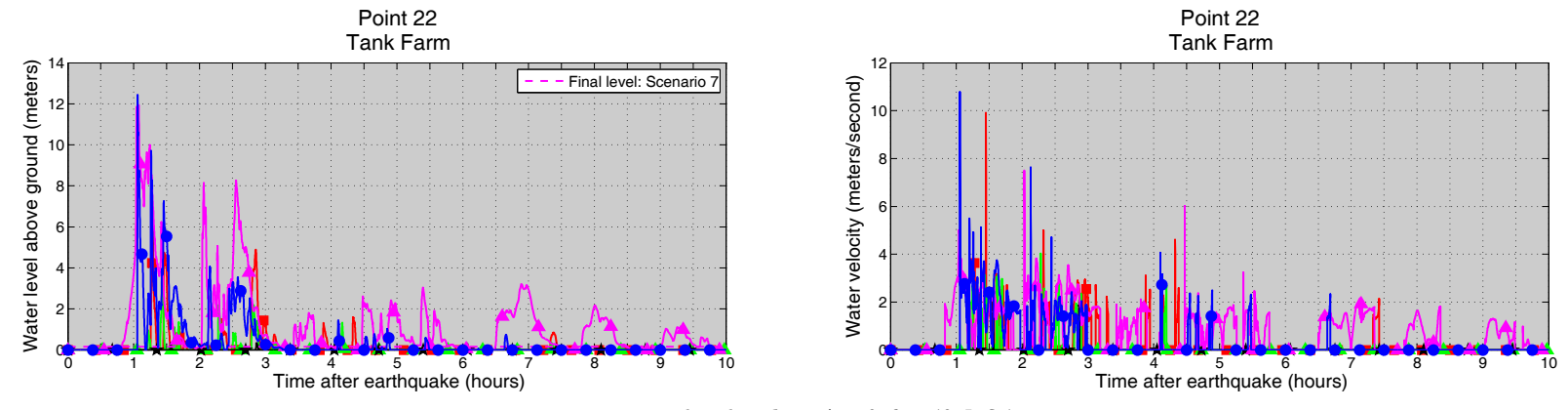

Pre-earthquake elevation $2.6 \mathrm{~m}(8.5 \mathrm{ft})$

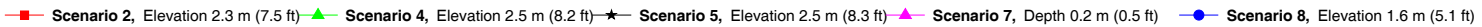

Point 23

Alaska Commercial Co.

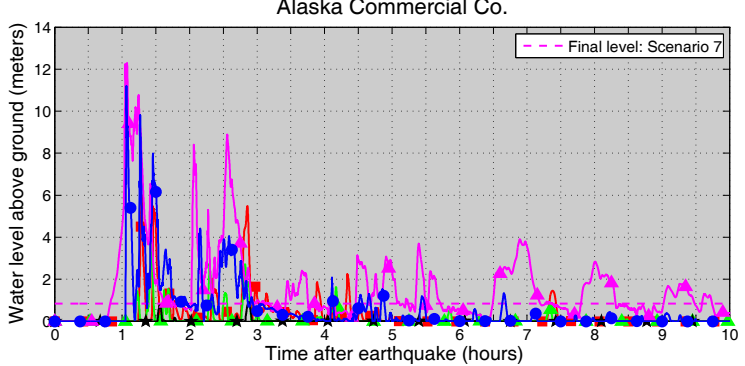

Point 23

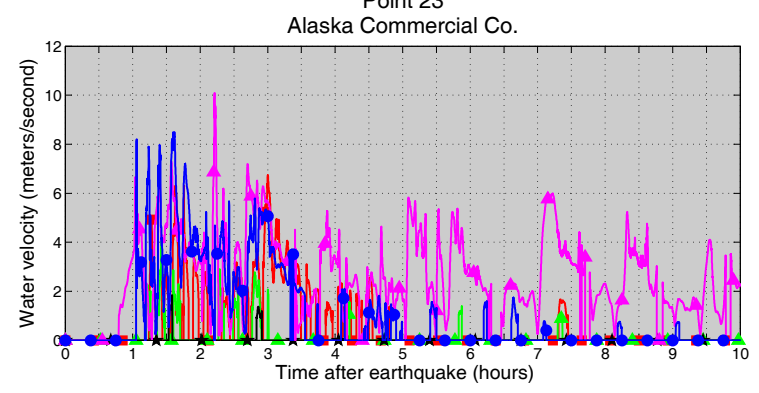

Pre-earthquake elevation $1.9 \mathrm{~m}(6.3 \mathrm{ft})$

- Scenario 2, Elevation $1.6 \mathrm{~m}(5.2 \mathrm{ft})-$ Scenario 4, Elevation $1.8 \mathrm{~m}(6.0 \mathrm{ft})-$ « Scenario 5 , Elevation $1.8 \mathrm{~m}(6.0 \mathrm{ft})-$ Scenario 7 , Depth $0.8 \mathrm{~m}(2.7 \mathrm{ft})-\bullet$ Scenario 8 , Elevation $0.9 \mathrm{~m}(2.9 \mathrm{ft})$

Point 24

Small Boat Harbor

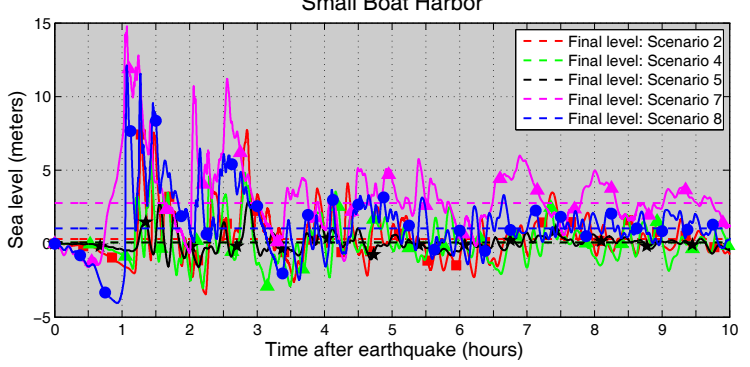

Point 24

Small Boat Harbor

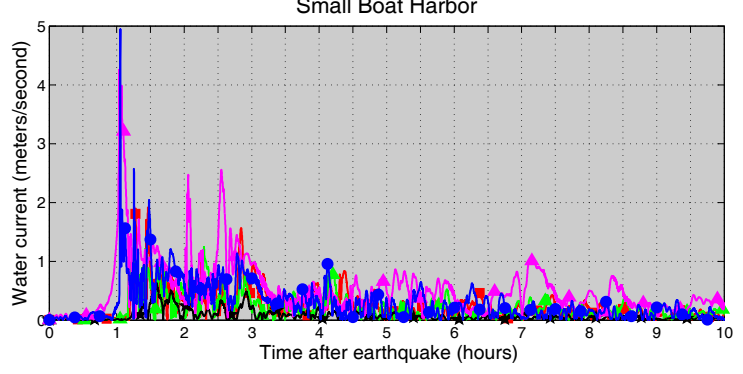

depth $7.5 \mathrm{~m}(24.7 \mathrm{ft})$

- Scenario 2, Depth $7.8 \mathrm{~m}(25.7 \mathrm{ft})-$ Scenario 4, Depth $7.6 \mathrm{~m}(25.0 \mathrm{ft}) \multimap$ Scenario 5, Depth $7.6 \mathrm{~m}(24.9 \mathrm{ft}) \longrightarrow$ Scenario 7 , Depth $10.3 \mathrm{~m}(33.7 \mathrm{ft}) \longrightarrow$ Scenario 8 , Depth $8.6 \mathrm{~m}(28.1 \mathrm{ft})$

Figure A-2 (cont.). Graphs showing time series of water level (left column) and velocity (right column) for selected locations in King Cove for scenarios 2, 4, 5, 7, and 8. For each location, pre-earthquake and post-earthquake elevation/depth corresponding to the MHHW datum is provided for each scenario. For some onshore locations, the post-earthquake value could be referenced as "depth" for some scenarios, and as "elevation" for others, indicating that different scenarios resulted in different amount of coseismic subsidence. For offshore locations, to show the height of an arriving tsunami, the vertical datum is such that zero corresponds to the pre-earthquake sea level. Dashed lines indicate the final water level after the tsunami. 

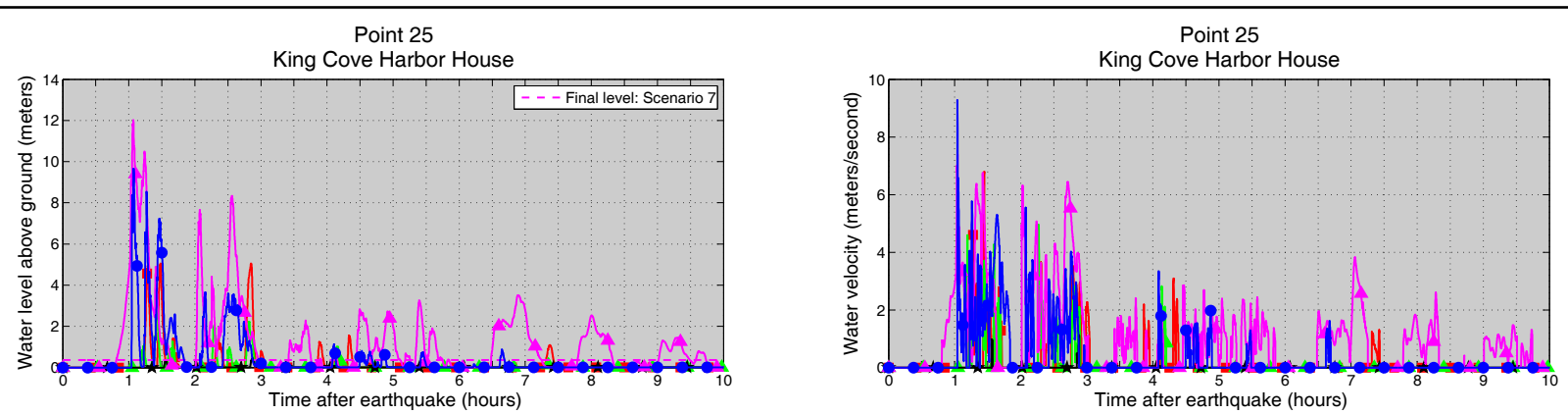

Pre-earthquake elevation $2.4 \mathrm{~m}(7.9 \mathrm{ft})$

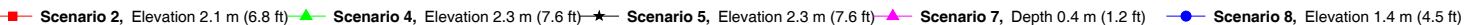
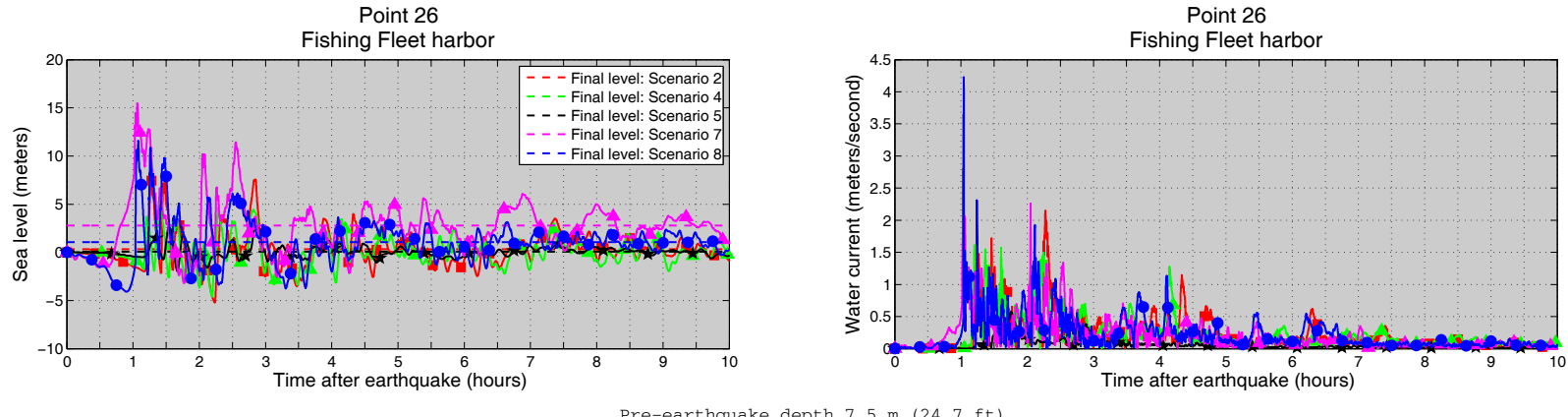

- Scenario 2, Depth $7.8 \mathrm{~m}(25.7 \mathrm{ft})-$ Scenario 4, Depth $7.6 \mathrm{~m}(24.9 \mathrm{ft}) \multimap$ Scenario 5, Depth $7.6 \mathrm{~m}(24.9 \mathrm{ft}) \longrightarrow$ Scenario 7, Depth $10.3 \mathrm{~m}(33.8 \mathrm{ft})-$ Scenario 8 , Depth $8.6 \mathrm{~m}(28.1 \mathrm{ft})$

Point 27

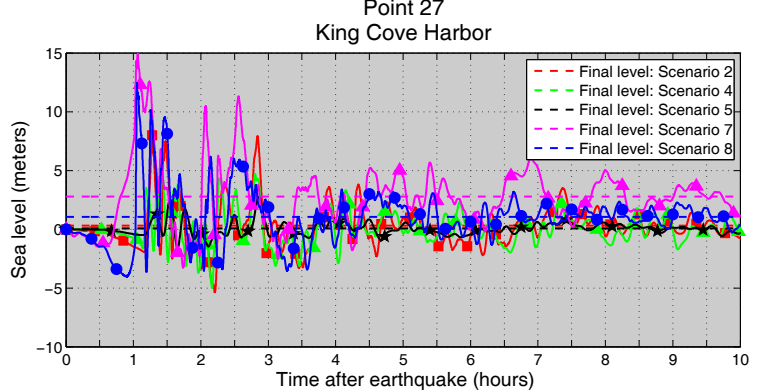

Pre-earthquake depth $27.9 \mathrm{~m}(91.5 \mathrm{ft}$

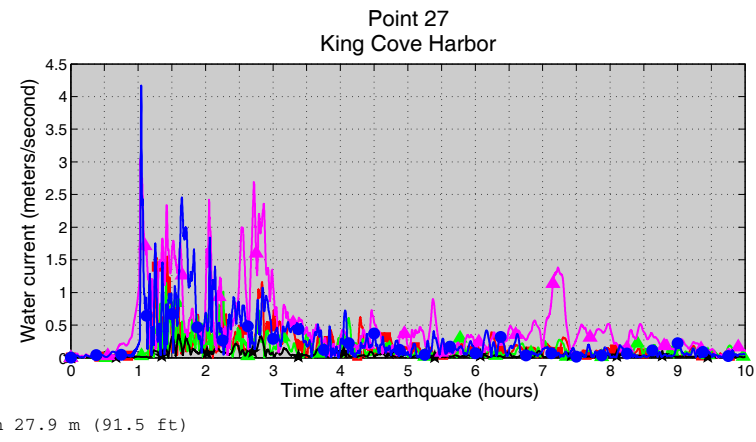

- Scenario 2, Depth $28.2 \mathrm{~m}(92.5 \mathrm{ft}) \longrightarrow$ Scenario 4, Depth $28.0 \mathrm{~m}(91.7 \mathrm{ft}) \rightarrow$ Scenario 5, Depth $28.0 \mathrm{~m}(91.7 \mathrm{ft}) \longrightarrow$ Scenario 7 , Depth $30.7 \mathrm{~m}(100.6 \mathrm{ft}) \longrightarrow$ Scenario 8 , Depth $28.9 \mathrm{~m}(94.9 \mathrm{ft})$

Point 28

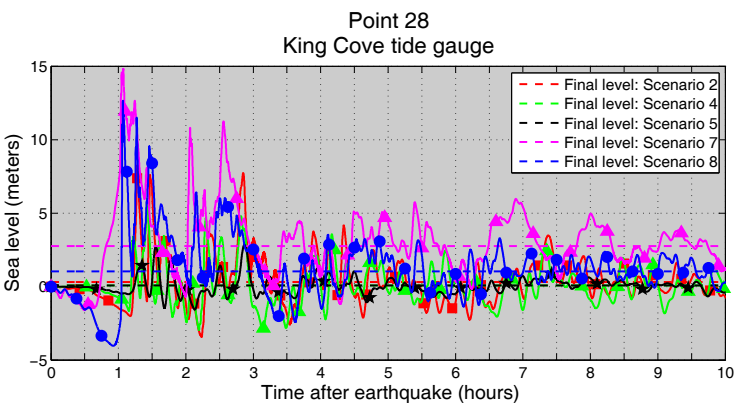

Pre-earthquake depth $9.1 \mathrm{~m}(29.9 \mathrm{ft})$
Point 28

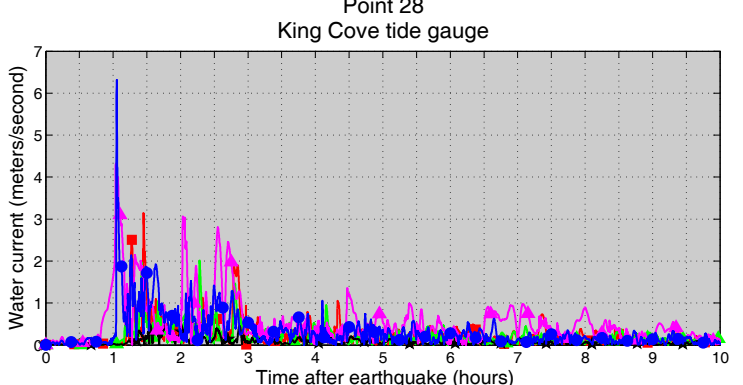

- Scenario 2, Depth $9.4 \mathrm{~m}(31.0 \mathrm{ft}) \longrightarrow$ Scenario 4, Depth $9.2 \mathrm{~m}(30.2 \mathrm{ft}) \multimap$ Scenario 5, Depth $9.2 \mathrm{~m}(30.2 \mathrm{ft}) \longrightarrow$ Scenario 7, Depth $11.9 \mathrm{~m}(39.0 \mathrm{ft}) \longrightarrow$ Scenario 8 , Depth $10.2 \mathrm{~m}(33.3 \mathrm{ft})$

Figure A-2 (cont.). Graphs showing time series of water level (left column) and velocity (right column) for selected locations in King Cove for scenarios 2, 4, 5, 7, and 8. For each location, pre-earthquake and post-earthquake elevation/depth corresponding to the MHHW datum is provided for each scenario. For some onshore locations, the post-earthquake value could be referenced as "depth" for some scenarios, and as "elevation" for others, indicating that different scenarios resulted in different amount of coseismic subsidence. For offshore locations, to show the height of an arriving tsunami, the vertical datum is such that zero corresponds to the pre-earthquake sea level. Dashed lines indicate the final water level after the tsunami. 

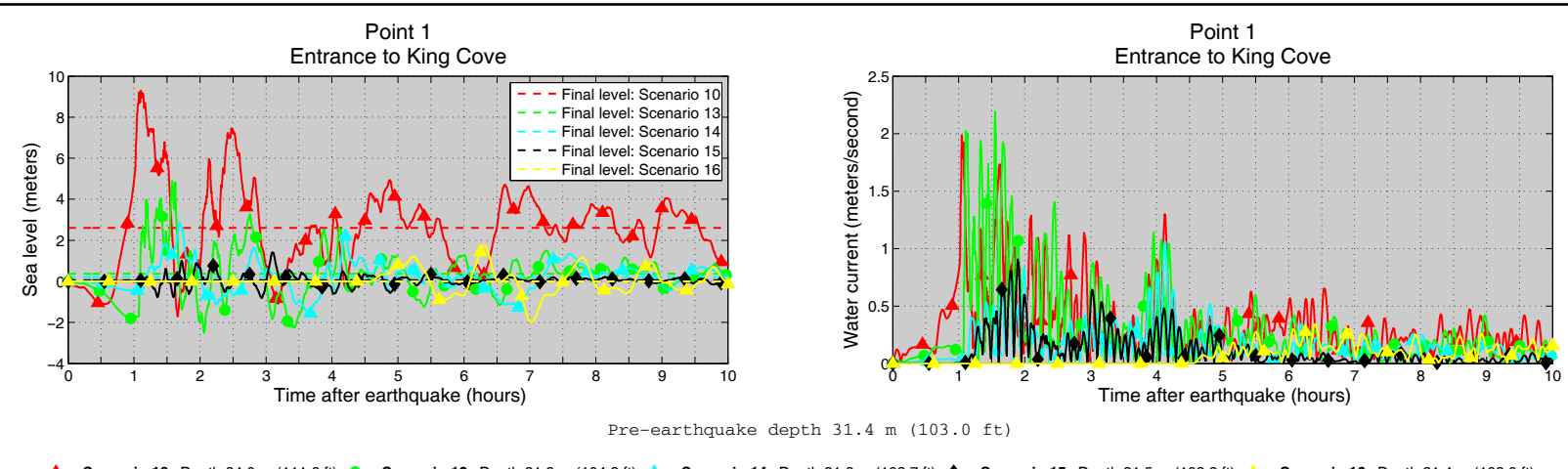

$\_$Scenario 10, Depth $34.0 \mathrm{~m}(111.6 \mathrm{ft})-$ Scenario 13, Depth $31.8 \mathrm{~m}(104.2 \mathrm{ft}) \backsim$ Scenario 14, Depth $31.6 \mathrm{~m}(103.7 \mathrm{ft}) \multimap-$ Scenario 15, Depth $31.5 \mathrm{~m}(103.2 \mathrm{ft})-$ Scenario 16, Depth $31.4 \mathrm{~m}(103.0 \mathrm{ft})$
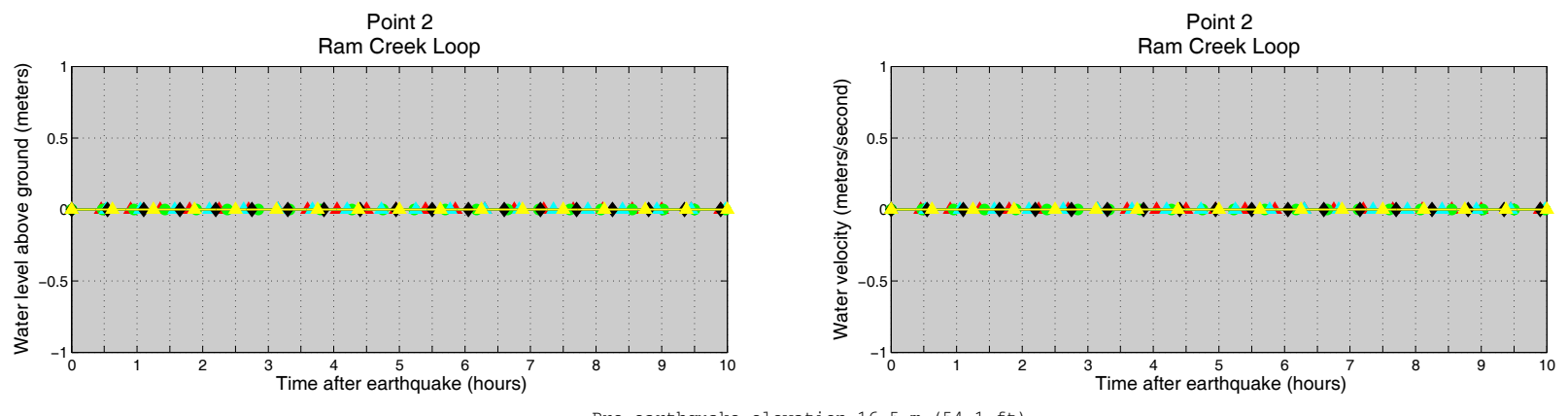

Pre-earthquake elevation $16.5 \mathrm{~m}(54.1 \mathrm{ft})$

- Scenario 10, Elevation $13.8 \mathrm{~m}(45.4 \mathrm{ft})-$ - Scenario 13, Elevation $16.1 \mathrm{~m}(52.8 \mathrm{ft})-$ Scenario 14, Elevation $16.3 \mathrm{~m}(53.4 \mathrm{ft}) \multimap-$ Scenario 15 , Elevation $16.4 \mathrm{~m}(53.9 \mathrm{ft})-$ Scenario 16 , Elevation $16.5 \mathrm{~m}(54.1 \mathrm{ft})$
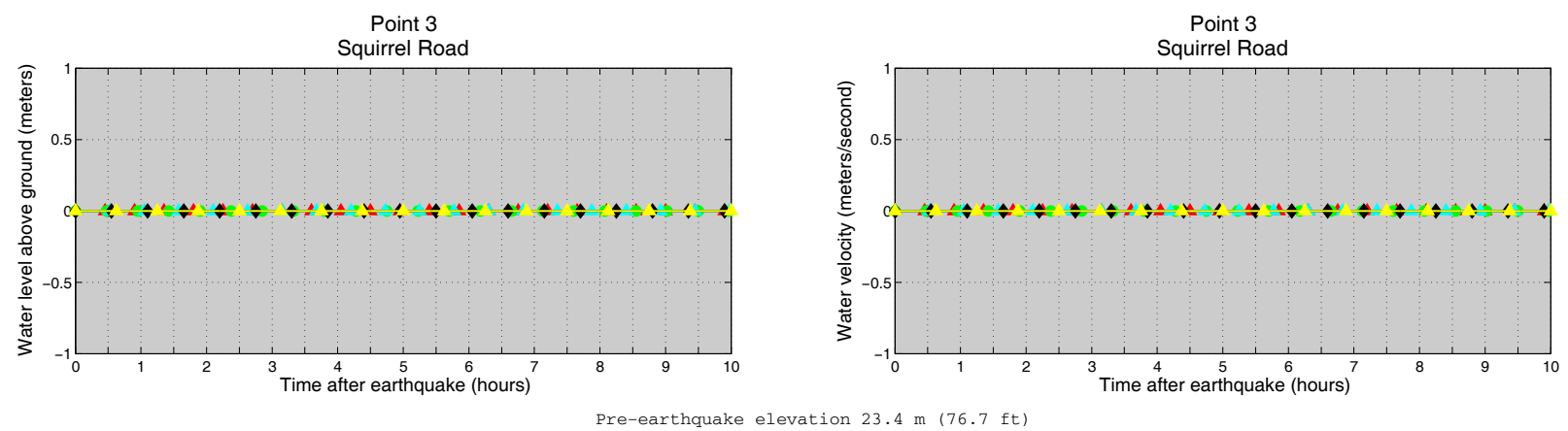

- Scenario 10, Elevation $20.8 \mathrm{~m}(68.1 \mathrm{ft})-$ Scenario 13, Elevation $23.0 \mathrm{~m}(75.5 \mathrm{ft})-$ Scenario 14, Elevation $23.2 \mathrm{~m}(76.0 \mathrm{ft}) \multimap-$ Scenario 15 , Elevation $23.3 \mathrm{~m}(76.5 \mathrm{ft})-$ Scenario 16 , Elevation $23.4 \mathrm{~m}(76.7 \mathrm{ft})$

Point 4

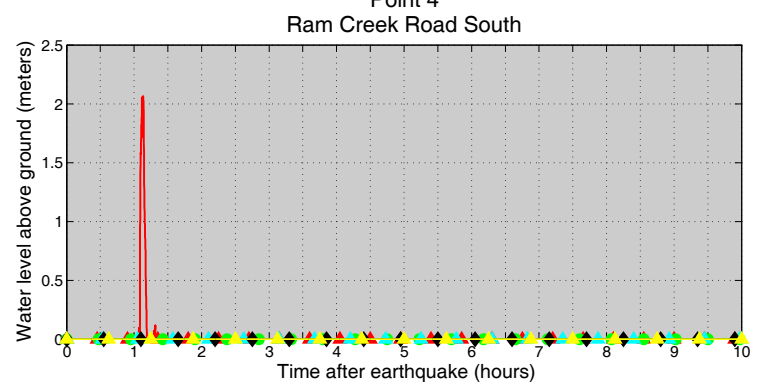

Point 4

Ram Creek Road South

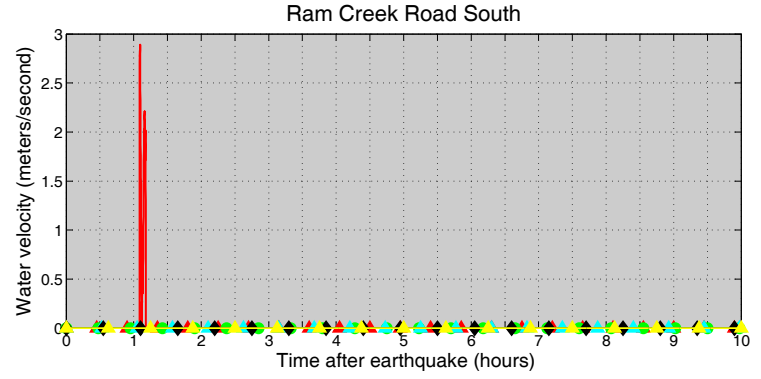

Scenario 16, Elevation $8.3 \mathrm{~m}(27.2 \mathrm{ft})$

Figure A-3. Graphs showing time series of water level (left column) and velocity (right column) for selected locations in King Cove for scenarios 10,13,14, 15, and 16. For each location, pre-earthquake and post-earthquake depth corresponding to the MHHW is provided for each scenario. For offshore locations, to show the height of an arriving tsunami, the vertical datum is such that zero corresponds to the pre-earthquake sea level. Dashed lines show the water level after the tsunami. 

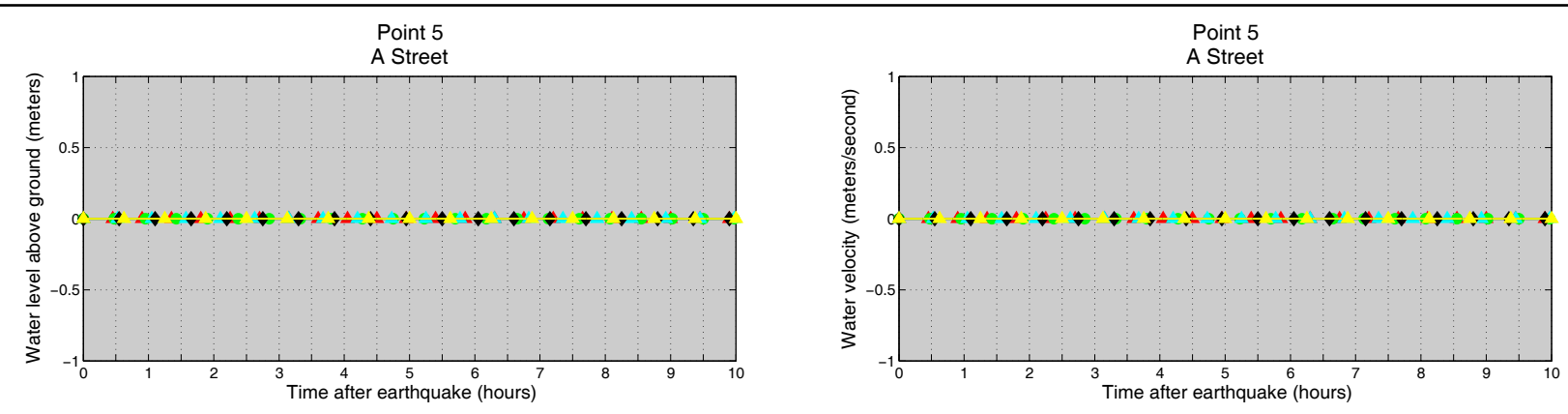

Pre-earthquake elevation $23.1 \mathrm{~m}(75.9 \mathrm{ft})$

- Scenario 10, Elevation $20.5 \mathrm{~m}(67.3 \mathrm{ft}) \bullet-$ Scenario 13, Elevation $22.8 \mathrm{~m}(74.7 \mathrm{ft}) \sim$ Scenario 14, Elevation $22.9 \mathrm{~m}(75.2 \mathrm{ft}) \multimap$ Scenario 15 , Elevation $23.1 \mathrm{~m}(75.7 \mathrm{ft})-$ Scenario 16 , Elevation $23.1 \mathrm{~m}(75.9 \mathrm{ft})$
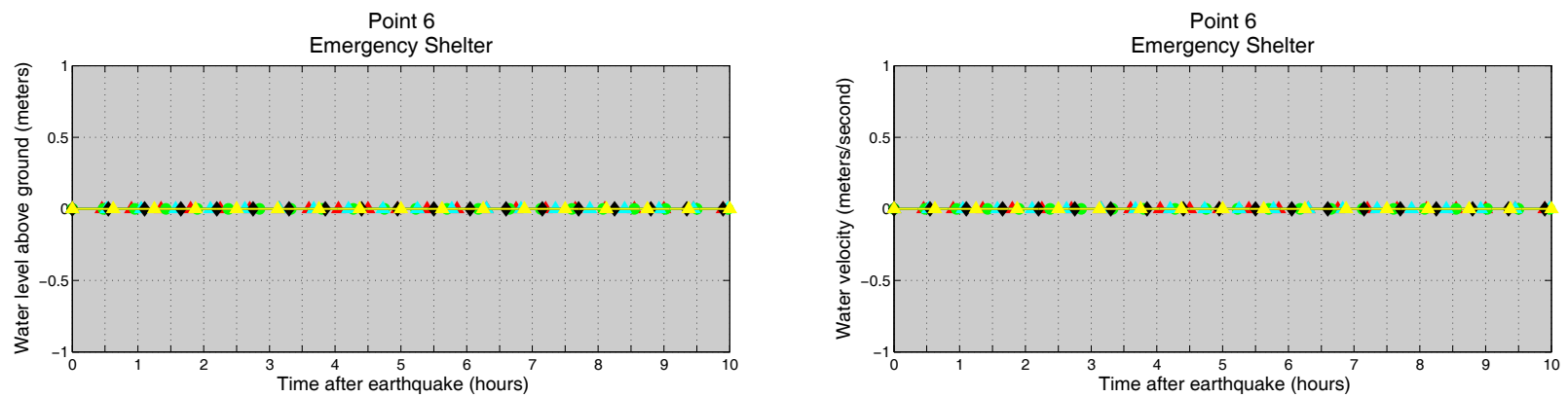

Pre-earthquake elevation $24.9 \mathrm{~m}(81.5 \mathrm{ft})$

- Scenario 10, Elevation $22.3 \mathrm{~m}(73.0 \mathrm{ft})-$ Scenario 13, Elevation $24.5 \mathrm{~m}(80.3 \mathrm{ft})-$ Scenario 14, Elevation $24.6 \mathrm{~m}(80.8 \mathrm{ft}) \longrightarrow$ Scenario 15 , Elevation $24.8 \mathrm{~m}(81.3 \mathrm{ft})-$ Scenario 16 , Elevation $24.9 \mathrm{~m}(81.5 \mathrm{ft})$
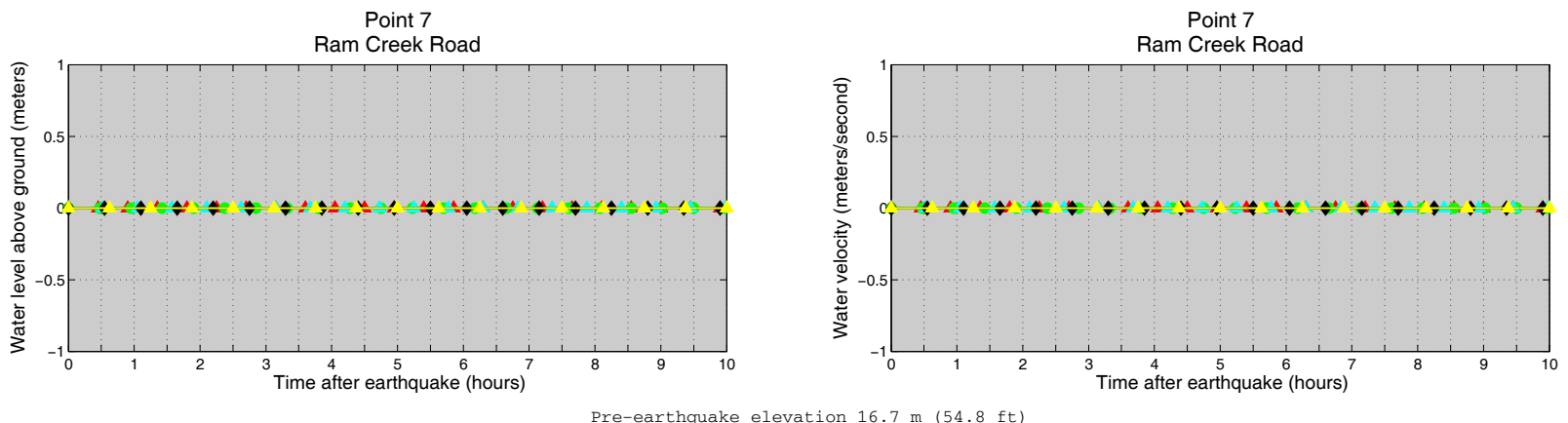

Pre-earthquake elevation $16.7 \mathrm{~m}(54.8 \mathrm{ft})$

- Scenario 10, Elevation $14.1 \mathrm{~m}(46.4 \mathrm{ft})-$ Scenario 13, Elevation $16.3 \mathrm{~m}(53.6 \mathrm{ft})-$ Scenario 14 , Elevation $16.5 \mathrm{~m}(54.1 \mathrm{ft}) \multimap-$ Scenario 15 , Elevation $16.6 \mathrm{~m}(54.6 \mathrm{ft})-$ Scenario 16 , Elevation $16.7 \mathrm{~m}(54.8 \mathrm{ft})$

Point 8

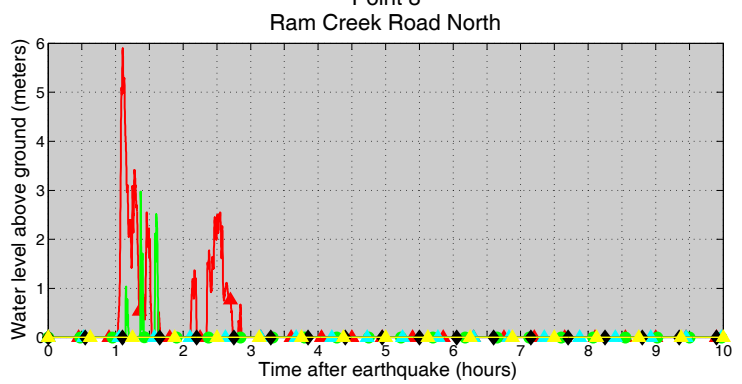

Pre-earthquake elevation $5.1 \mathrm{~m}(16.6 \mathrm{ft})$
Point 8

Ram Creek Road North

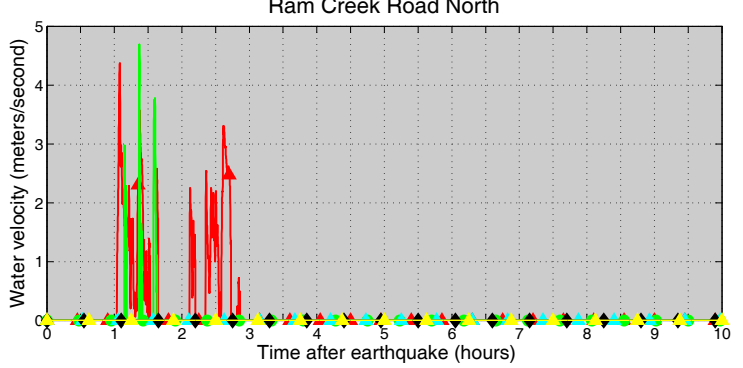

Time after earthquake (hours)

— Scenario 10, Elevation $2.5 \mathrm{~m}(8.3 \mathrm{ft}) \longrightarrow$ Scenario 13, Elevation $4.7 \mathrm{~m}(15.4 \mathrm{ft})-$ Scenario 14, Elevation $4.9 \mathrm{~m}(15.9 \mathrm{ft}) \longrightarrow$ Scenario 15 , Elevation $5.0 \mathrm{~m}(16.4 \mathrm{ft})-$ Scenario 16 , Elevation $5.1 \mathrm{~m}(16.6 \mathrm{ft})$

Figure A-3 (cont.). Graphs showing time series of water level (left column) and velocity (right column) for selected locations in King Cove for scenarios 10,13, 14, 15, and 16. For each location, pre-earthquake and post-earthquake depth corresponding to the MHHW is provided for each scenario. For offshore locations, to show the height of an arriving tsunami, the vertical datum is such that zero corresponds to the pre-earthquake sea level. Dashed lines show the water level after the tsunami. 

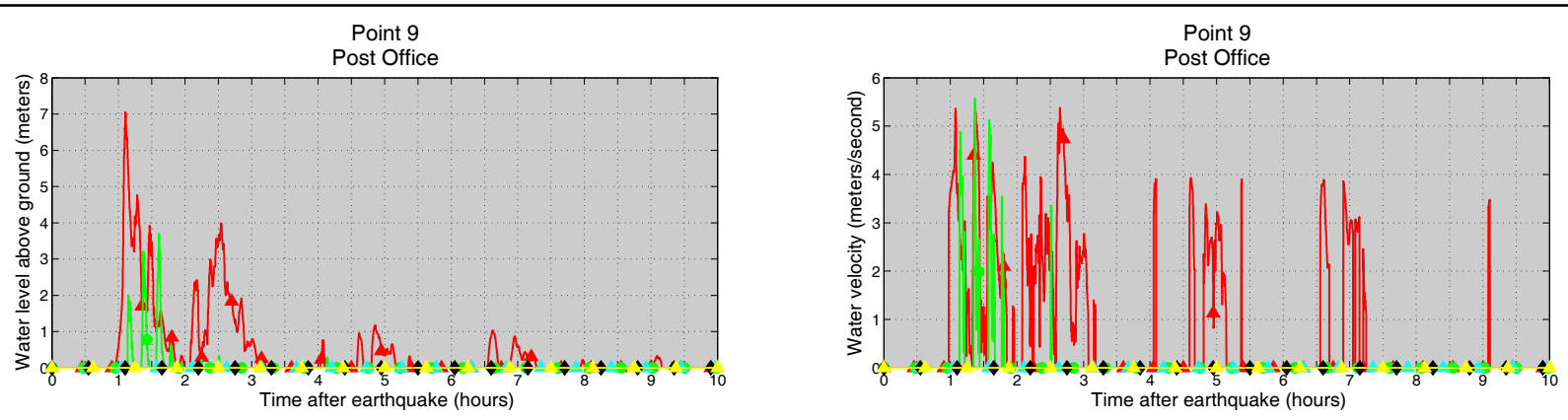

Pre-earthquake elevation $3.6 \mathrm{~m}(11.8 \mathrm{ft})$

$\_$Scenario 10, Elevation $1.1 \mathrm{~m}(3.6 \mathrm{ft}) \longrightarrow$ Scenario 13, Elevation $3.2 \mathrm{~m}(10.7 \mathrm{ft}) \sim$ Scenario 14, Elevation $3.4 \mathrm{~m}(11.1 \mathrm{ft}) \multimap-$ Scenario 15, Elevation $3.5 \mathrm{~m}(11.6 \mathrm{ft})-$ Scenario 16 , Elevation $3.6 \mathrm{~m}(11.8 \mathrm{ft})$
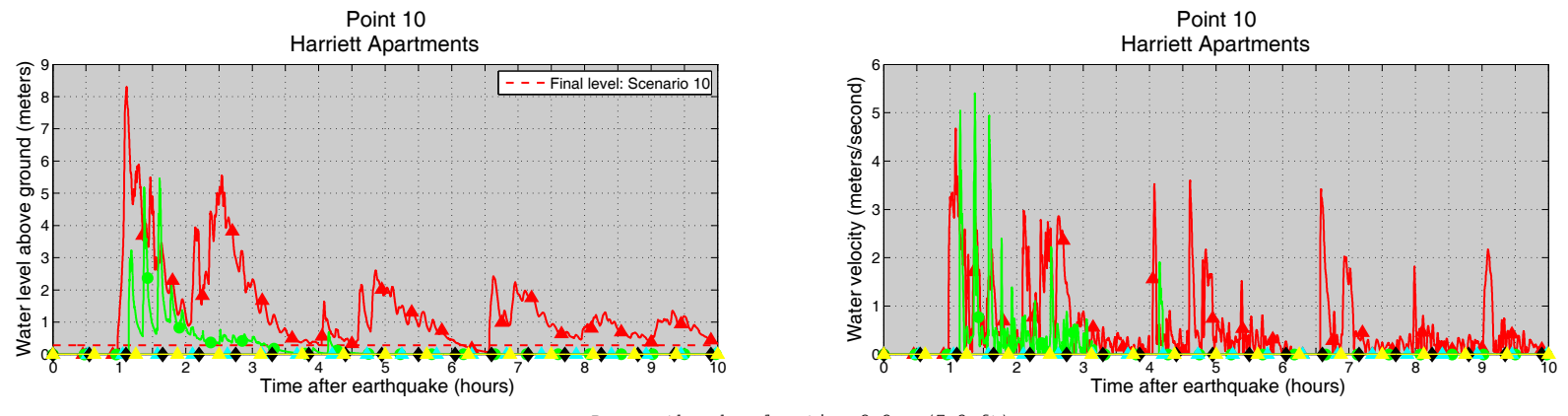

— Scenario 10, Depth $0.3 \mathrm{~m}(0.9 \mathrm{ft}) \longrightarrow$ Scenario 13, Elevation $1.9 \mathrm{~m}(6.2 \mathrm{ft})-$ Scenario 14, Elevation $2.0 \mathrm{~m}(6.6 \mathrm{ft}) \longrightarrow$ Scenario 15 , Elevation $2.2 \mathrm{~m}(7.1 \mathrm{ft})-$ Scenario 16 , Elevation $2.2 \mathrm{~m}(7.3 \mathrm{ft})$
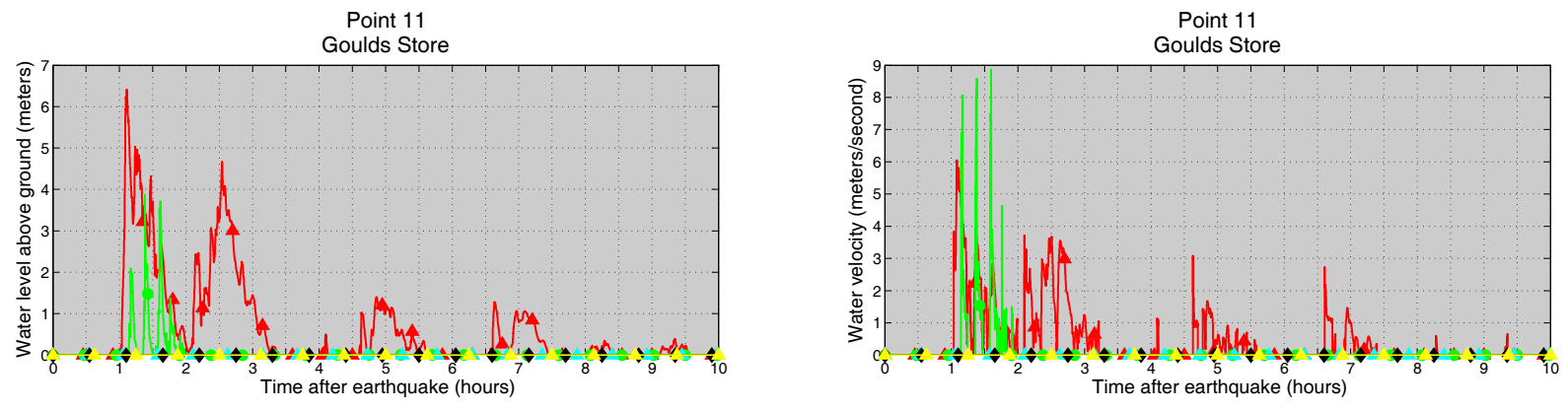

- Scenario 10, Elevation $0.6 \mathrm{~m}(2.1 \mathrm{ft}) \longrightarrow$ Scenario 13, Elevation $2.8 \mathrm{~m}(9.1 \mathrm{ft}) \longrightarrow$ Scenario 14, Elevation $2.9 \mathrm{~m}(9.6 \mathrm{ft}) \longrightarrow$ Scenario 15 , Elevation $3.1 \mathrm{~m}(10.1 \mathrm{ft})-$ Scenario 16 , Elevation $3.1 \mathrm{~m}(10.3 \mathrm{ft})$
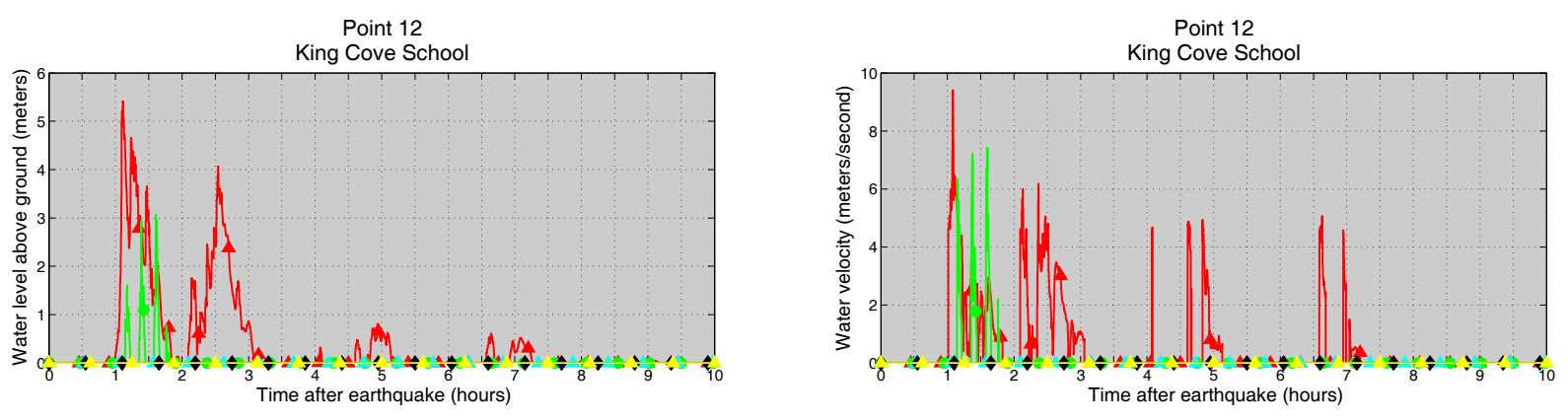

ake elevation $3.7 \mathrm{~m}(12.0 \mathrm{ft})$

—- Scenario 10, Elevation $1.2 \mathrm{~m}(3.8 \mathrm{ft})-\bullet$ Scenario 13, Elevation $3.3 \mathrm{~m}(10.9 \mathrm{ft})-$ Scenario 14, Elevation $3.5 \mathrm{~m}(11.3 \mathrm{ft}) \multimap-$ Scenario 15 , Elevation $3.6 \mathrm{~m}(11.8 \mathrm{ft})$

Scenario 16, Elevation $3.7 \mathrm{~m}(12.0 \mathrm{ft})$

Figure A-3 (cont.). Graphs showing time series of water level (left column) and velocity (right column) for selected locations in King Cove for scenarios 10,13,14, 15, and 16. For each location, pre-earthquake and post-earthquake depth corresponding to the MHHW is provided for each scenario. For offshore locations, to show the height of an arriving tsunami, the vertical datum is such that zero corresponds to the pre-earthquake sea level. Dashed lines show the water level after the tsunami. 

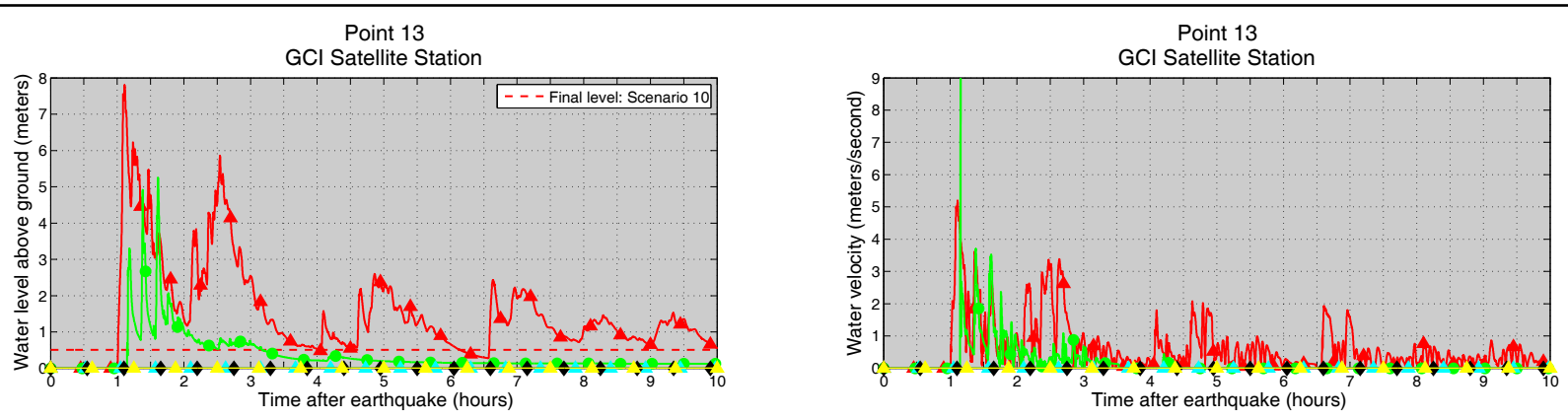

Pre-earthquake elevation $2.0 \mathrm{~m}(6.6 \mathrm{ft})$

$\triangle$ Scenario 10, Depth $0.5 \mathrm{~m}(1.6 \mathrm{ft})-\longrightarrow$ Scenario 13, Elevation $1.7 \mathrm{~m}(5.4 \mathrm{ft})-$ Scenario 14, Elevation $1.8 \mathrm{~m}(5.9 \mathrm{ft}) \longrightarrow$ Scenario 15, Elevation $1.9 \mathrm{~m}(6.4 \mathrm{ft})-$ Scenario 16 , Elevation $2.0 \mathrm{~m}(6.6 \mathrm{ft})$
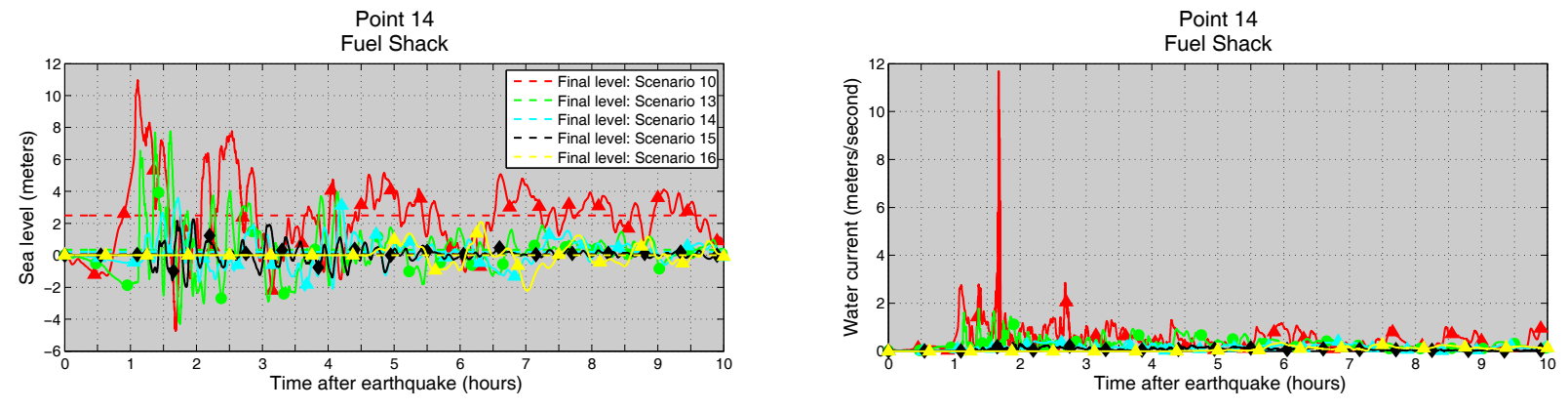

- Scenario 10, Depth $7.2 \mathrm{~m}(23.7 \mathrm{ft})-$ Scenario 13, Depth $5.1 \mathrm{~m}(16.6 \mathrm{ft})-$ Scenario 14, Depth $4.9 \mathrm{~m}(16.2 \mathrm{ft}) \longrightarrow$ Scenario 15, Depth $4.8 \mathrm{~m}(15.7 \mathrm{ft})-$ Scenario 16, Depth $4.7 \mathrm{~m}(15.5 \mathrm{ft})$
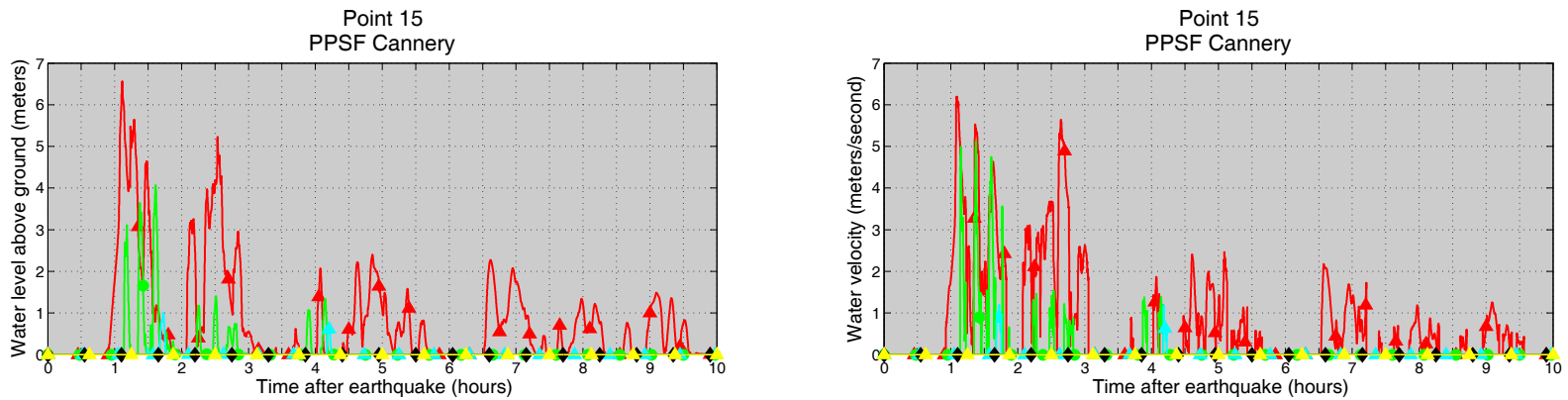

$\smile$ Scenario 10, Elevation $0.0 \mathrm{~m}(0.1 \mathrm{ft})-$ Scenario 13, Elevation $2.2 \mathrm{~m}(7.1 \mathrm{ft})-$ Scenario 14, Elevation $2.3 \mathrm{~m}(7.6 \mathrm{ft}) \multimap-$ Scenario 15 , Elevation $2.5 \mathrm{~m}(8.1 \mathrm{ft}) \leadsto$ Scenario 16 , Elevation $2.5 \mathrm{~m}(8.2 \mathrm{ft})$

Point 16

PPSF Laundry Room

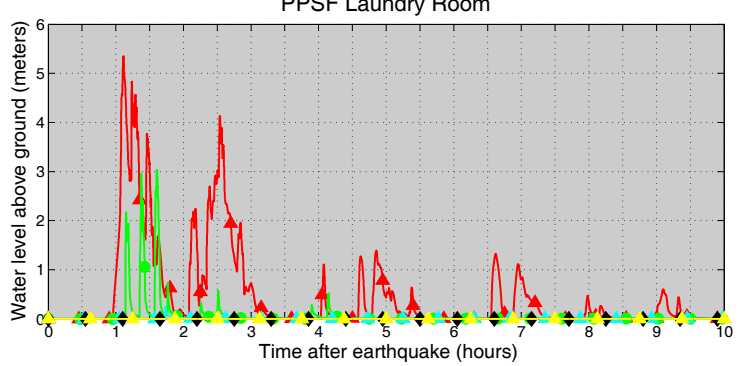

Pre-earthquake elevation $3.5 \mathrm{~m}(11.4 \mathrm{ft})$
Point 16

PPSF Laundry Room

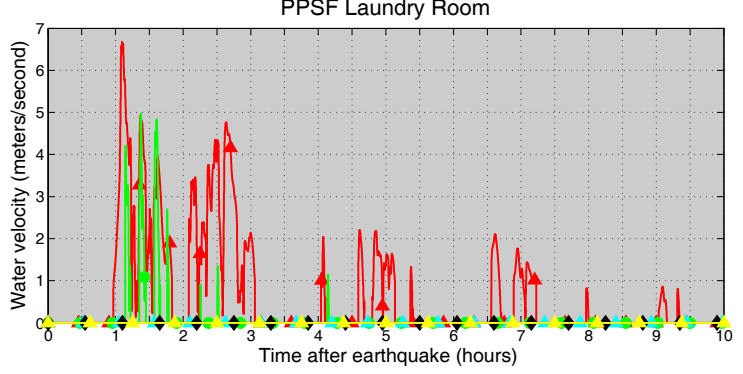

$\_$Scenario 10, Elevation $1.0 \mathrm{~m}(3.2 \mathrm{ft}) \longrightarrow$ Scenario 13, Elevation $3.1 \mathrm{~m}(10.2 \mathrm{ft}) \sim$ Scenario 14, Elevation $3.3 \mathrm{~m}(10.7 \mathrm{ft})-$ Scenario 15 , Elevation $3.4 \mathrm{~m}(11.2 \mathrm{ft})-$ Scenario 16 , Elevation $3.5 \mathrm{~m}(11.4 \mathrm{ft})$

Figure A-3 (cont.). Graphs showing time series of water level (left column) and velocity (right column) for selected locations in King Cove for scenarios 10, 13, 14, 15, and 16. For each location, pre-earthquake and post-earthquake depth corresponding to the MHHW is provided for each scenario. For offshore locations, to show the height of an arriving tsunami, the vertical datum is such that zero corresponds to the pre-earthquake sea level. Dashed lines show the water level after the tsunami. 

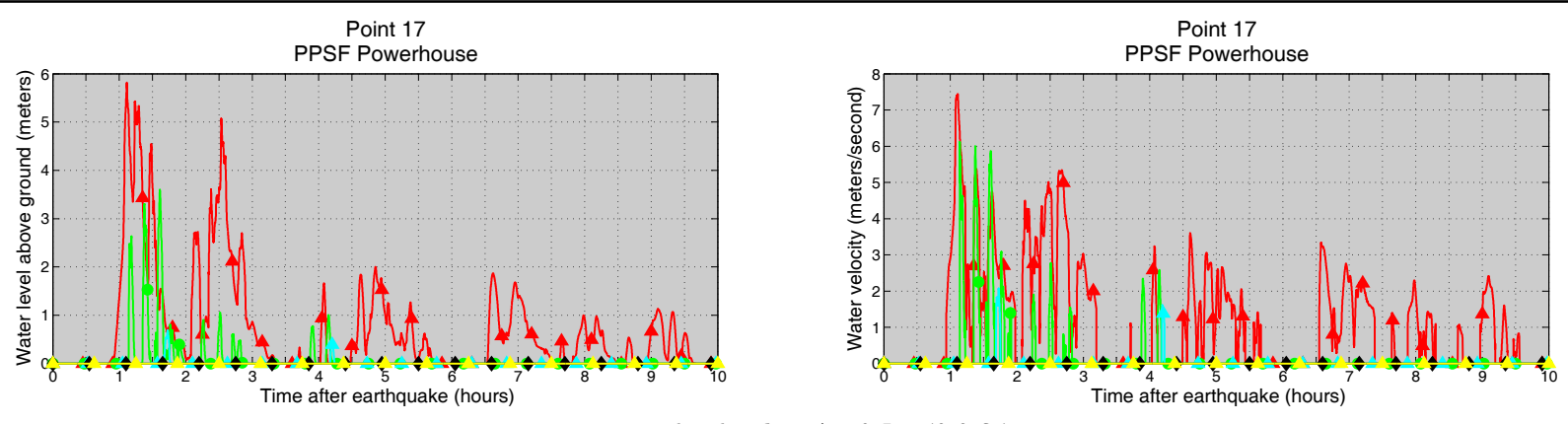

Pre-earthquake elevation $2.7 \mathrm{~m}(8.8 \mathrm{ft})$

—- Scenario 10, Elevation $0.2 \mathrm{~m}(0.6 \mathrm{ft})-$ Scenario 13, Elevation $2.3 \mathrm{~m}(7.6 \mathrm{ft}) \sim$ Scenario 14, Elevation $2.5 \mathrm{~m}(8.1 \mathrm{ft}) \multimap-$ Scenario 15, Elevation $2.6 \mathrm{~m}(8.6 \mathrm{ft})-$ Scenario 16 , Elevation $2.7 \mathrm{~m}(8.8 \mathrm{ft})$
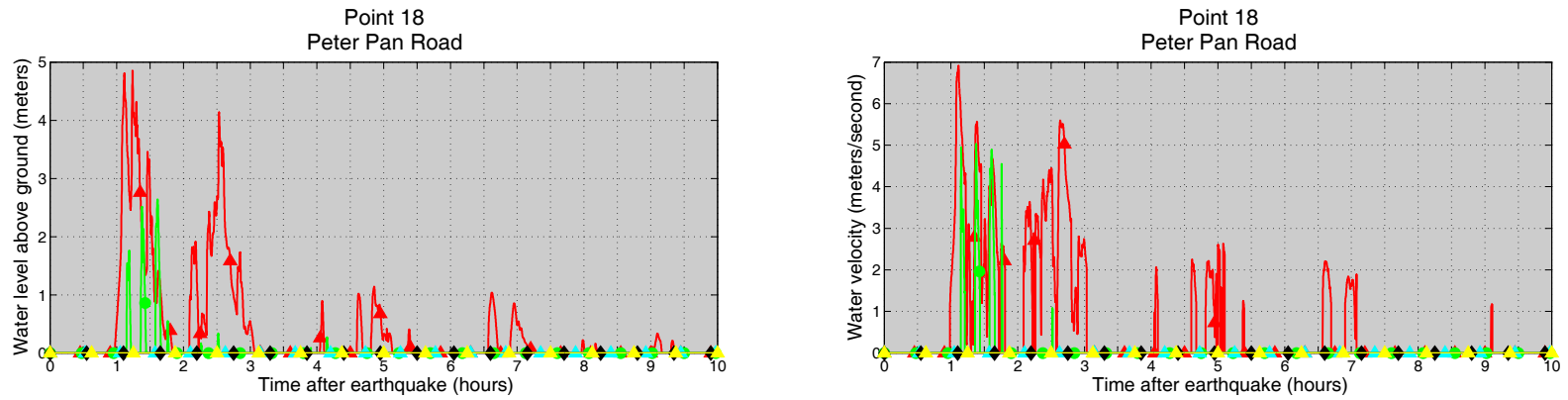

Pre-earthquake elevation $3.6 \mathrm{~m}(12.0 \mathrm{ft})$

—- Scenario 10, Elevation $1.2 \mathrm{~m}(3.8 \mathrm{ft}) \longrightarrow$ Scenario 13, Elevation $3.3 \mathrm{~m}(10.8 \mathrm{ft}) \_$Scenario 14, Elevation $3.4 \mathrm{~m}(11.3 \mathrm{ft})-$ Scenario 15 , Elevation $3.6 \mathrm{~m}(11.8 \mathrm{ft})-$ Scenario 16 , Elevation $3.6 \mathrm{~m}(12.0 \mathrm{ft})$

Point 19

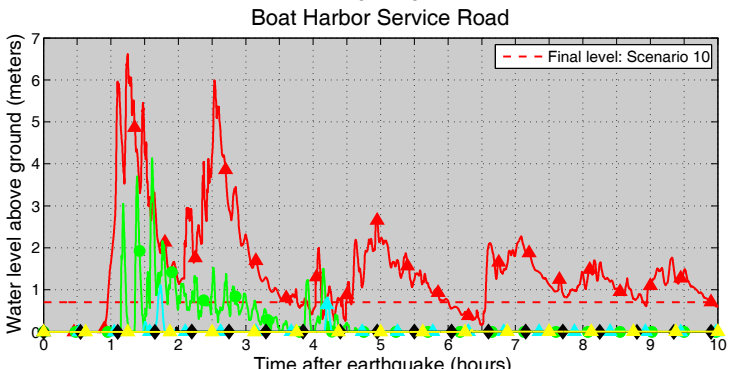

Pre-earthquake elevation $1.8 \mathrm{~m}(5.8 \mathrm{ft})$
Point 19

Boat Harbor Service Road

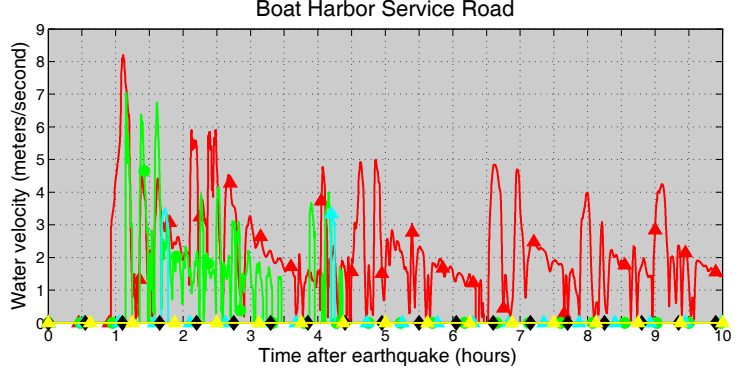

Scenario 15, Elevation $1.7 \mathrm{~m}(5.7 \mathrm{ft})-$ Scenario 16, Elevation $1.8 \mathrm{~m}(5.8 \mathrm{ft})$
Point 20

Communications Building

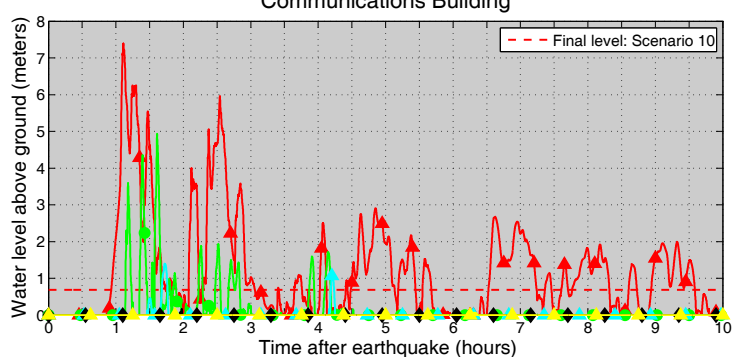

Point 20

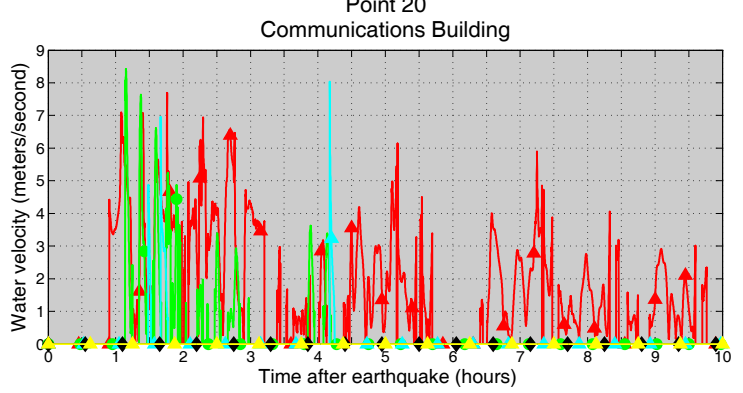

Pre-earthquake elevation $1.8 \mathrm{~m}(5.9 \mathrm{ft})$

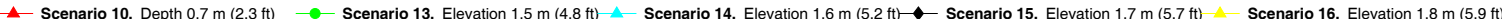

Figure A-3 (cont.). Graphs showing time series of water level (left column) and velocity (right column) for selected locations in King Cove for scenarios 10,13,14, 15, and 16. For each location, pre-earthquake and post-earthquake depth corresponding to the MHHW is provided for each scenario. For offshore locations, to show the height of an arriving tsunami, the vertical datum is such that zero corresponds to the pre-earthquake sea level. Dashed lines show the water level after the tsunami. 

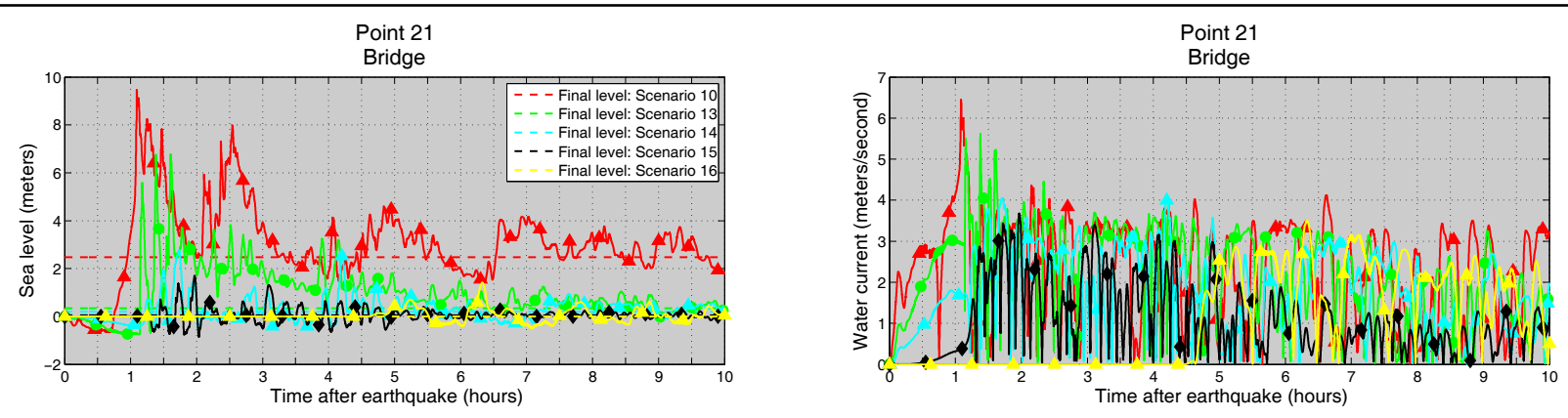

Pre-earthquake depth $2.2 \mathrm{~m}(7.1 \mathrm{ft})$

$\triangle$ Scenario 10, Depth $4.6 \mathrm{~m}(15.2 \mathrm{ft})-$ Scenario 13, Depth $2.5 \mathrm{~m}(8.2 \mathrm{ft}) \longrightarrow$ Scenario 14, Depth $2.4 \mathrm{~m}(7.8 \mathrm{ft}) \longrightarrow$ Scenario 15, Depth $2.2 \mathrm{~m}(7.3 \mathrm{ft}) \longrightarrow$ Scenario 16 , Depth $2.2 \mathrm{~m}(7.1 \mathrm{ft})$
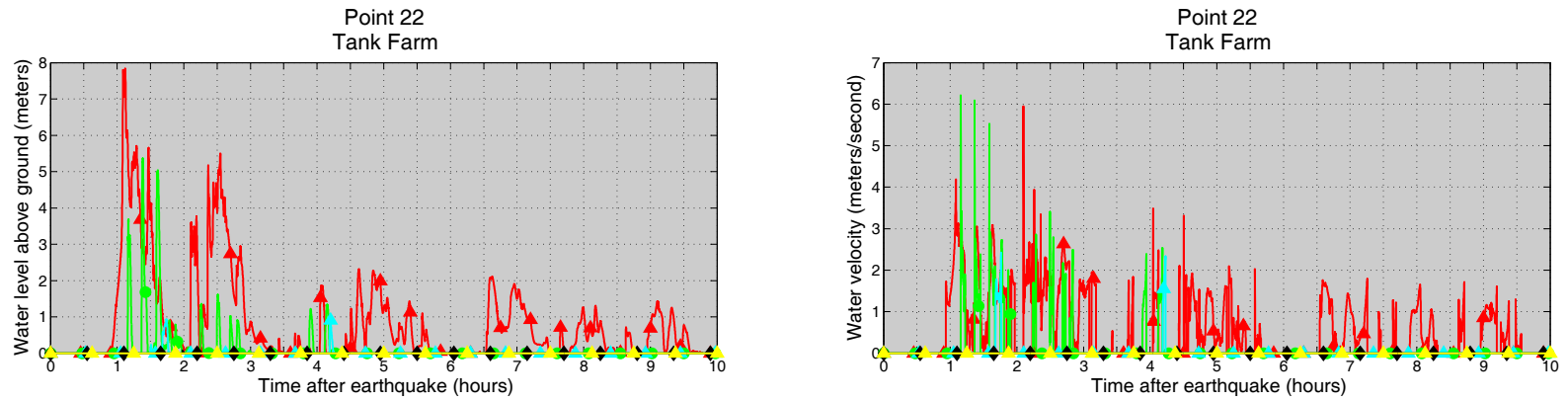

Pre-earthquake elevation $2.6 \mathrm{~m}(8.5 \mathrm{ft})$

$\_$Scenario 10, Elevation $0.1 \mathrm{~m}(0.4 \mathrm{ft})-$ - Scenario 13, Elevation $2.2 \mathrm{~m}(7.4 \mathrm{ft}) \backsim$ Scenario 14, Elevation $2.4 \mathrm{~m}(7.8 \mathrm{ft}) \multimap$ Scenario 15, Elevation $2.5 \mathrm{~m}(8.3 \mathrm{ft})-$ Scenario 16 , Elevation $2.6 \mathrm{~m}(8.5 \mathrm{ft})$

Point 23

Alaska Commercial Co.

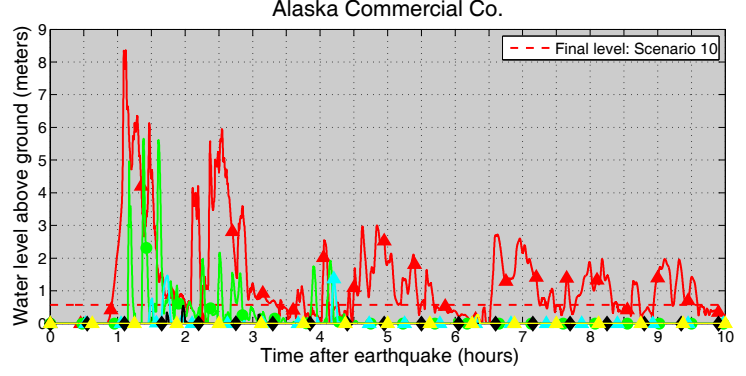

Pre-earthquake elevation $1.9 \mathrm{~m}(6.3 \mathrm{ft})$
Point 23

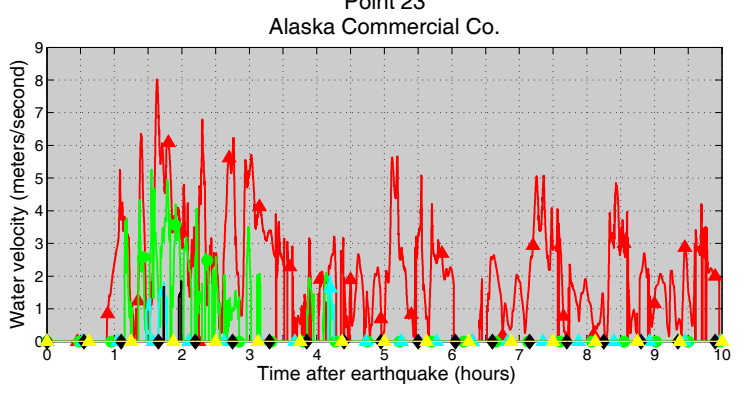

- Scenario 10, Depth $0.6 \mathrm{~m}(1.9 \mathrm{ft}) \longrightarrow$ Scenario 13, Elevation $1.6 \mathrm{~m}(5.1 \mathrm{ft})-$ Scenario 14, Elevation $1.7 \mathrm{~m}(5.6 \mathrm{ft}) \longrightarrow$ Scenario 15 , Elevation $1.9 \mathrm{~m}(6.1 \mathrm{ft})-$ Scenario 16 , Elevation $1.9 \mathrm{~m}(6.3 \mathrm{ft})$

Point 24

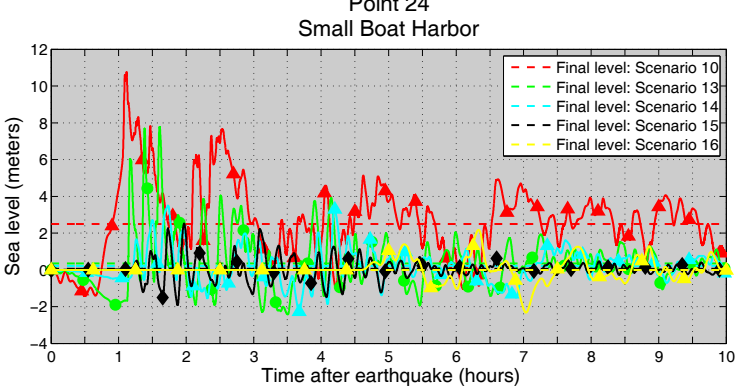

Point 24

Small Boat Harbor

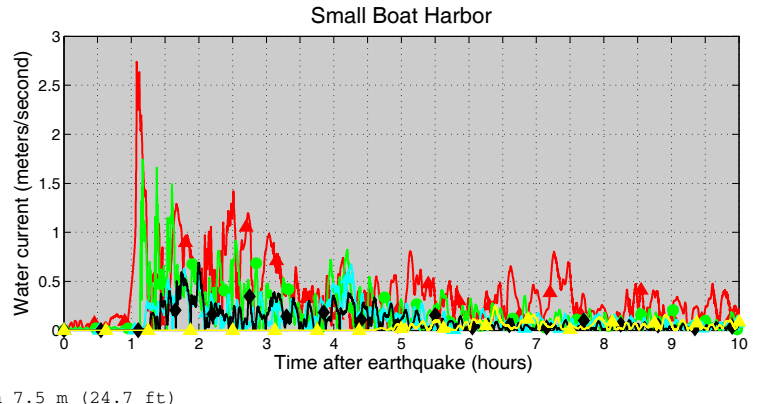

Pre-earthquake depth $7.5 \mathrm{~m}(24.7 \mathrm{ft})$

— Scenario 10, Depth $10.0 \mathrm{~m}(32.9 \mathrm{ft})-$ - Scenario 13, Depth $7.9 \mathrm{~m}(25.8 \mathrm{ft}) \longrightarrow$ Scenario 14, Depth $7.7 \mathrm{~m}(25.4 \mathrm{ft}) \longrightarrow$ Scenario 15, Depth $7.6 \mathrm{~m}(24.9 \mathrm{ft})$

Scenario 16, Depth $7.5 \mathrm{~m}(24.7 \mathrm{ft})$

Figure A-3 (cont.). Graphs showing time series of water level (left column) and velocity (right column) for selected locations in King Cove for scenarios 10, 13, 14, 15, and 16. For each location, pre-earthquake and post-earthquake depth corresponding to the MHHW is provided for each scenario. For offshore locations, to show the height of an arriving tsunami, the vertical datum is such that zero corresponds to the pre-earthquake sea level. Dashed lines show the water level after the tsunami. 

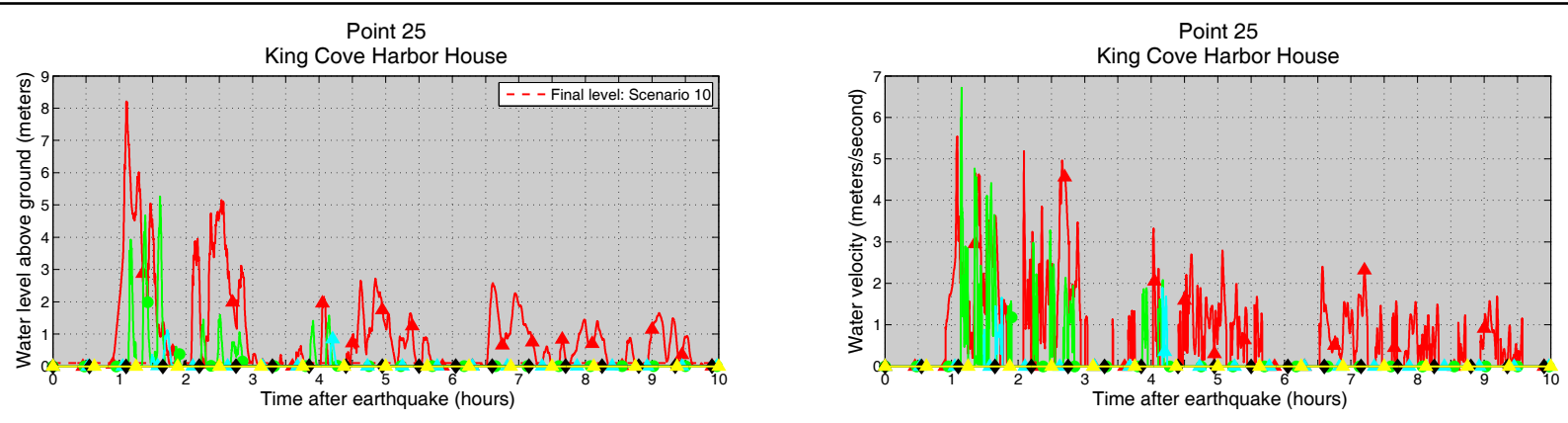

Pre-earthquake elevation $2.4 \mathrm{~m}(7.9 \mathrm{ft})$

—- Scenario 10, Depth $0.1 \mathrm{~m}(0.3 \mathrm{ft}) \multimap$ Scenario 13, Elevation $2.1 \mathrm{~m}(6.7 \mathrm{ft})-$ Scenario 14, Elevation $2.2 \mathrm{~m}(7.2 \mathrm{ft}) \multimap-$ Scenario 15 , Elevation $2.3 \mathrm{~m}(7.7 \mathrm{ft}) \wedge$ Scenario 16 , Elevation $2.4 \mathrm{~m}(7.9 \mathrm{ft})$
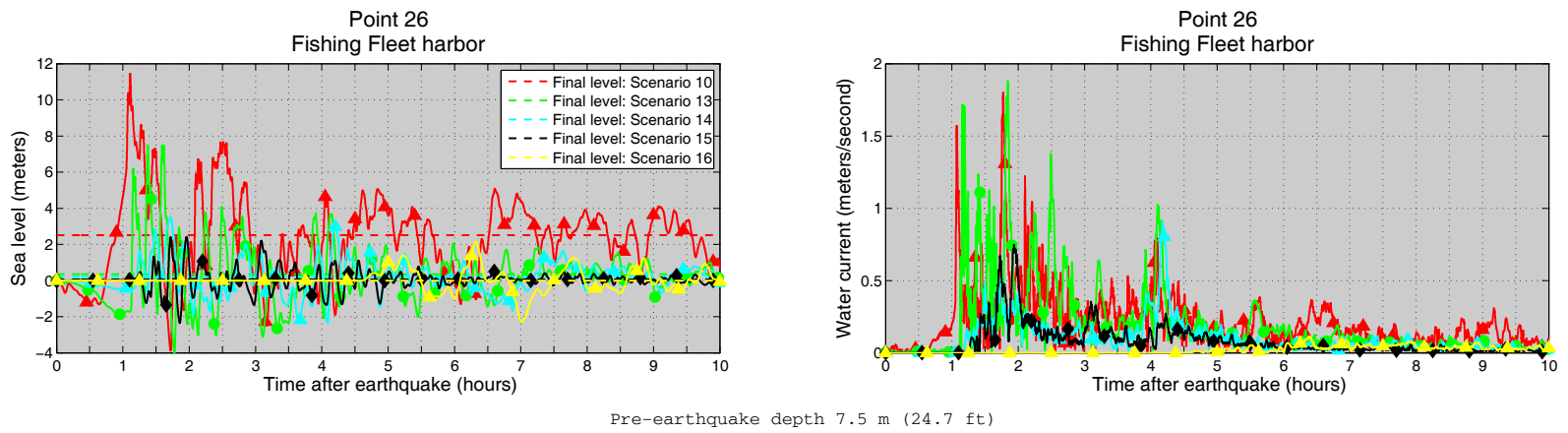

— Scenario 10, Depth $10.0 \mathrm{~m}(32.9 \mathrm{ft}) \multimap$ - Scenario 13, Depth $7.9 \mathrm{~m}(25.8 \mathrm{ft}) \longrightarrow$ Scenario 14, Depth $7.7 \mathrm{~m}(25.3 \mathrm{ft}) \longrightarrow$ Scenario 15, Depth $7.6 \mathrm{~m}(24.8 \mathrm{ft}) \longrightarrow$ Scenario 16, Depth $7.5 \mathrm{~m}(24.7 \mathrm{ft})$

Point 27

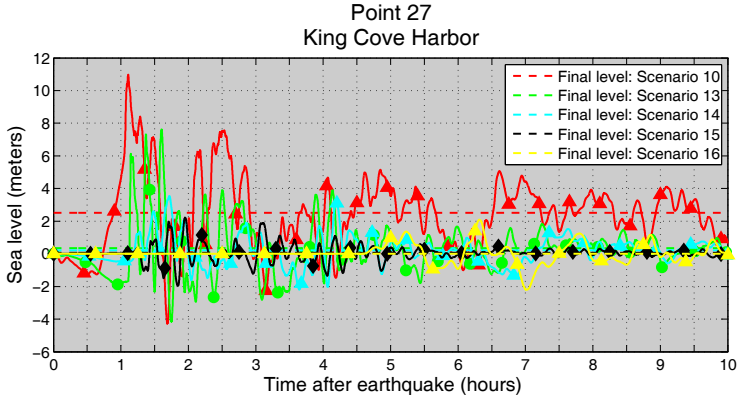

Pre-earthquake depth $27.9 \mathrm{~m}(91.5 \mathrm{ft})$
Point 27

King Cove Harbor

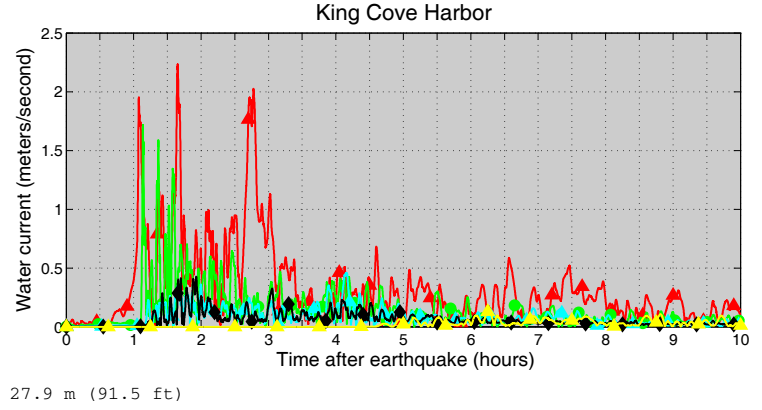

Scenario 16, Depth $27.9 \mathrm{~m}(91.5 \mathrm{ft})$
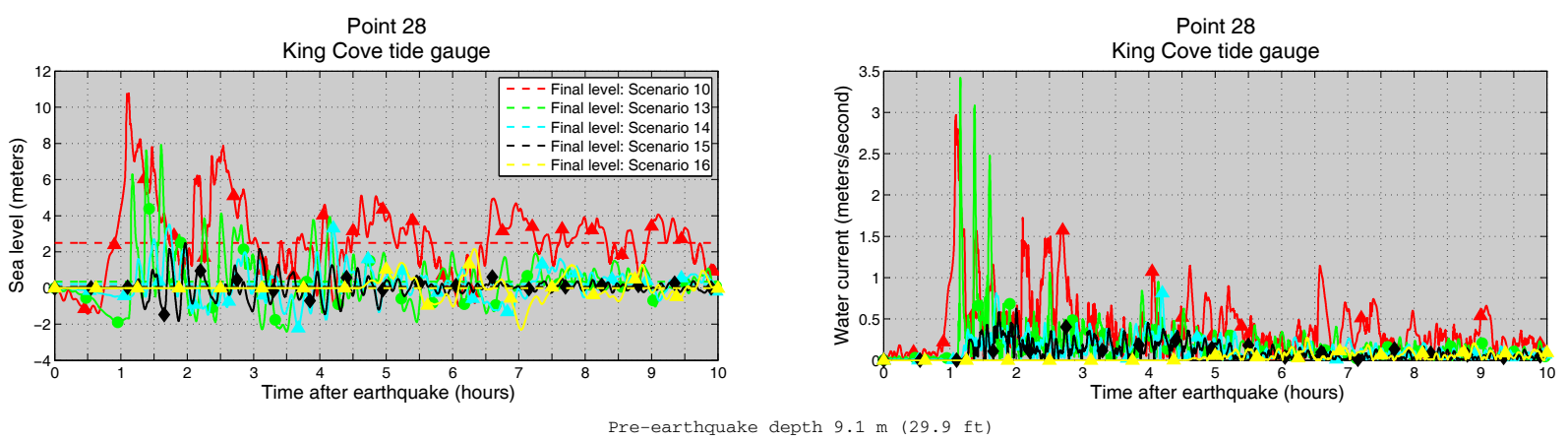

— Scenario 10, Depth $11.6 \mathrm{~m}(38.1 \mathrm{ft})-$ Scenario 13, Depth $9.5 \mathrm{~m}(31.1 \mathrm{ft})-$ Scenario 14, Depth $9.3 \mathrm{~m}(30.6 \mathrm{ft}) \longrightarrow$ Scenario 15, Depth $9.2 \mathrm{~m}(30.1 \mathrm{ft})-$ Scenario 16 , Depth $9.1 \mathrm{~m}(29.9 \mathrm{ft})$

Figure A-3 (cont.). Graphs showing time series of water level (left column) and velocity (right column) for selected locations in King Cove for scenarios 10,13,14,15, and 16. For each location, pre-earthquake and post-earthquake depth corresponding to the MHHW is provided for each scenario. For offshore locations, to show the height of an arriving tsunami, the vertical datum is such that zero corresponds to the pre-earthquake sea level. Dashed lines show the water level after the tsunami. 


\section{APPENDIX B \\ COLD BAY}

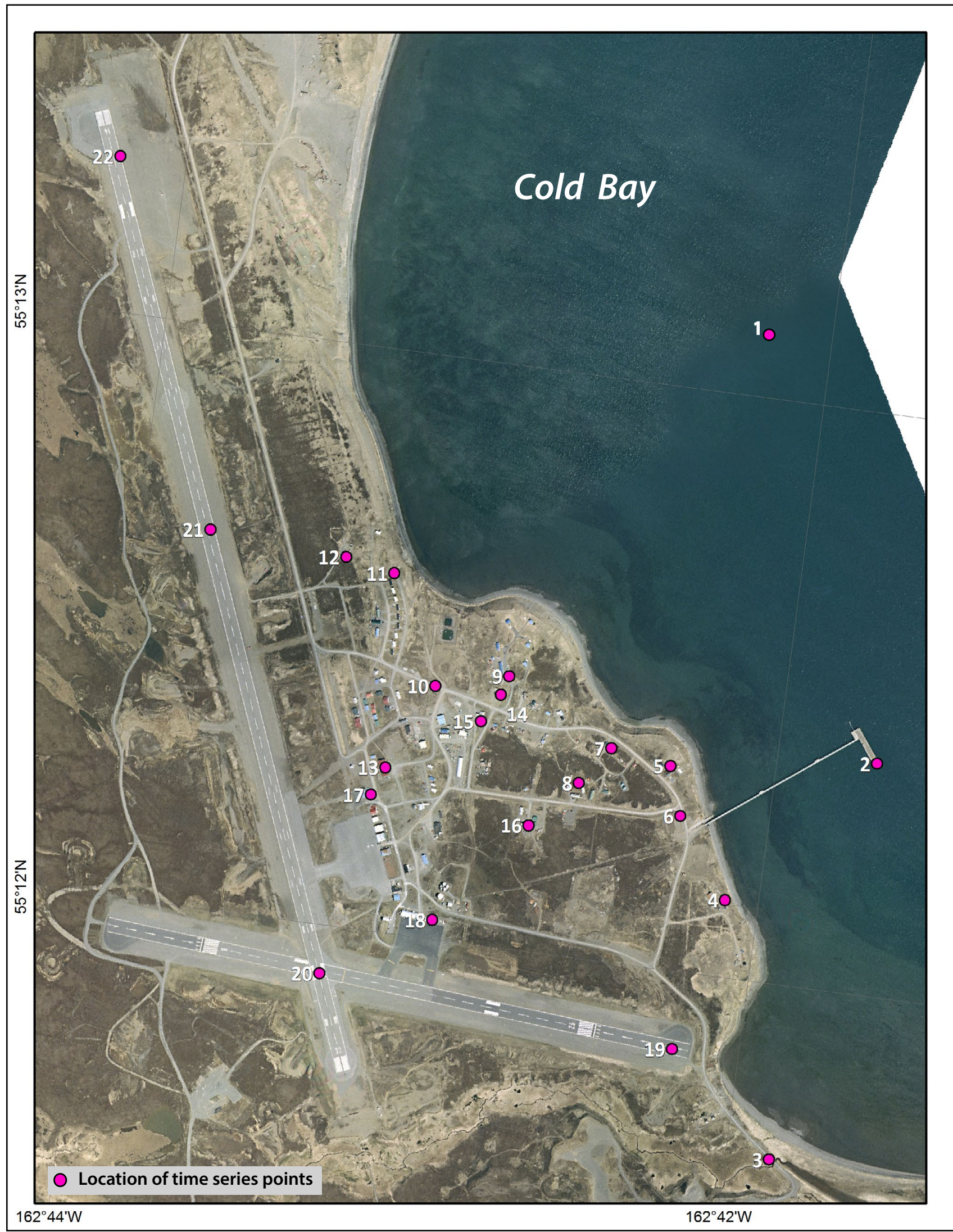

Figure B-1. Map showing locations of time series points in the community of Cold Bay. The latitude and longitude locations for time series points are listed in table B-1. 


\begin{tabular}{|c|c|c|c|c|c|c|c|c|c|c|c|c|c|c|c|c|c|c|c|c|c|c|c|}
\hline 亗 है & $\stackrel{0}{=}$ & $\exists$ & $\stackrel{?}{-}$ & 0 & 0 & 0 & 0 & 0 & 0 & 0 & 0 & 0 & 0 & 0 & 0 & 0 & 0 & 0 & 0 & 0 & 0 & 0 & 0 \\
\hline 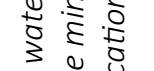 & $\because$ & $\stackrel{+}{0}$ & $\dot{0}$ & 0 & 0 & 0 & 0 & 0 & 0 & 0 & 0 & 0 & 0 & 0 & 0 & 0 & 0 & 0 & 0 & 0 & 0 & 0 & 0 \\
\hline & $\Xi$ & $\stackrel{+}{-}$ & $\stackrel{n}{-}$ & 0 & 0 & 0 & 0 & 0 & 0 & 0 & 0 & 0 & 0 & 0 & 0 & 0 & 0 & 0 & 0 & 0 & 0 & 0 & 0 \\
\hline & 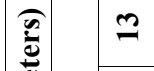 & $\stackrel{\infty}{-}$ & $\vec{i}$ & ĩ & 0 & 0 & 0 & 0 & 0 & 0 & 0 & 0 & 0 & 0 & 0 & 0 & 0 & 0 & 0 & 0 & 0 & 0 & 0 \\
\hline & $\simeq$ & $\exists$ & $?$ & 0 & 0 & 0 & 0 & 0 & 0 & 0 & 0 & 0 & 0 & 0 & 0 & 0 & 0 & 0 & 0 & 0 & 0 & 0 & 0 \\
\hline & $=$ & $\left|\begin{array}{l}\infty \\
i\end{array}\right|$ & $\begin{array}{l}0 \\
i \\
i\end{array} \mid$ & $\hat{i}$ & 0 & 0 & 0 & 0 & 0 & 0 & 0 & 0 & 0 & 0 & 0 & 0 & 0 & 0 & 0 & 0 & 0 & 0 & 0 \\
\hline & $\bar{E}$ & 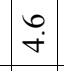 & $\begin{array}{c}\sim \\
i \\
i\end{array}$ & $\dot{m}$ & 0 & 0 & 0 & 0 & 0 & 0 & 0 & 0 & 0 & 0 & 0 & 0 & 0 & 0 & 0 & 0 & 0 & 0 & 0 \\
\hline & $\begin{array}{ll}5 \\
0 \\
0 \\
D\end{array}$ & $\stackrel{\sim}{\sim}$ & $m$ & $\stackrel{m}{m}$ & 0 & 0 & 0 & 0 & 0 & 0 & 0 & 0 & 0 & 0 & 0 & 0 & 0 & 0 & 0 & 0 & 0 & 0 & 0 \\
\hline & 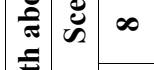 & in & \begin{tabular}{|l|}
0 \\
$\dot{n}$
\end{tabular} & $\nabla$ & 0 & 0 & 0 & 0 & 0 & 0 & 0 & 0 & 0 & 0 & 0 & 0 & 0 & 0 & 0 & 0 & 0 & 0 & 0 \\
\hline & : & $\begin{array}{l}\infty \\
i \\
\dot{n}\end{array}$ & 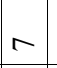 & $\mid \begin{array}{l}\infty \\
i \\
i n\end{array}$ & 0 & 0 & 0 & 0 & 0 & 0 & 0 & 0 & 0 & 0 & 0 & 0 & 0 & 0 & 0 & 0 & 0 & 0 & 0 \\
\hline & 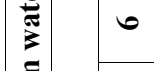 & $?$ & $\ddot{0}$ & 0 & 0 & 0 & 0 & 0 & 0 & 0 & 0 & 0 & 0 & 0 & 0 & 0 & 0 & 0 & 0 & 0 & 0 & 0 & 0 \\
\hline & . & $\grave{0}$ & $\hat{o}$ & 0 & 0 & 0 & 0 & 0 & 0 & 0 & 0 & 0 & 0 & 0 & 0 & 0 & 0 & 0 & 0 & 0 & 0 & 0 & 0 \\
\hline & $\nabla$ & $\stackrel{+}{-}$ & $\mathrm{N}$ & $\stackrel{n}{-}$ & 0 & 0 & 0 & 0 & 0 & 0 & 0 & 0 & 0 & 0 & 0 & 0 & 0 & 0 & 0 & 0 & 0 & 0 & 0 \\
\hline & $m$ & $\stackrel{\infty}{-\infty}$ & N & 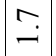 & 0 & 0 & 0 & 0 & 0 & 0 & 0 & 0 & 0 & 0 & 0 & 0 & 0 & 0 & 0 & 0 & 0 & 0 & 0 \\
\hline & $N$ & N & $\begin{array}{l}0 \\
i \\
i\end{array}$ & $\hat{i}$ & 0 & 0 & 0 & 0 & 0 & 0 & 0 & 0 & 0 & 0 & 0 & 0 & 0 & 0 & 0 & 0 & 0 & 0 & 0 \\
\hline & - & 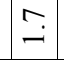 & $\hat{i}$ & $\mathrm{v}$ & 0 & 0 & 0 & 0 & 0 & 0 & 0 & 0 & 0 & 0 & 0 & 0 & 0 & 0 & 0 & 0 & 0 & 0 & 0 \\
\hline 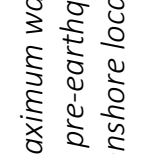 & 氖 & 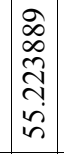 & $\mid \begin{array}{l}\hat{b} \\
0 \\
0 \\
0 \\
1 \\
n \\
n\end{array}$ & $\begin{array}{l}n \\
2 \\
2 \\
n \\
n\end{array}$ & 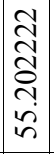 & $\begin{array}{c}n \\
\hat{\infty} \\
\infty \\
o \\
n \\
n \\
n\end{array}$ & 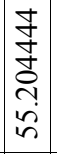 & $\begin{array}{l}= \\
\overline{1} \\
0 \\
i \\
i n \\
n \\
n\end{array}$ & $\begin{array}{l} \\
2 \\
\tilde{2} \\
n \\
n\end{array}$ & 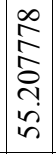 & 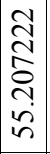 & 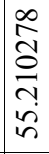 & $\begin{array}{l}0 \\
2 \\
o \\
\sim \\
n \\
n \\
n\end{array}$ & 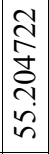 & 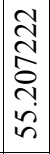 & $\begin{array}{l}2 \\
\infty \\
0 \\
0 \\
0 \\
i n \\
n \\
n\end{array}$ & 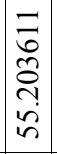 & $\begin{array}{c}2 \\
\infty \\
\infty \\
\infty \\
\tilde{0} \\
\tilde{n} \\
i n \\
n\end{array}$ & $\begin{array}{l}0 \\
2 \\
2 \\
o \\
n \\
n \\
n \\
n\end{array}$ & 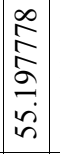 & \begin{tabular}{l}
$=$ \\
$\overline{0}$ \\
$\infty$ \\
2 \\
\hdashline \\
$n$ \\
$n$ \\
$n$
\end{tabular} & & 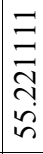 \\
\hline 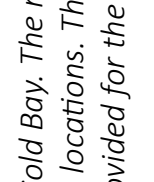 & 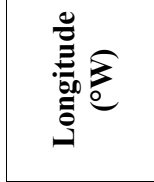 & 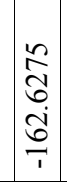 & $\begin{array}{l} \\
2 \\
\hat{o} \\
i \\
0 \\
1\end{array}$ & 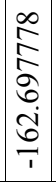 & 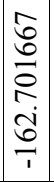 & 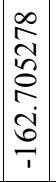 & 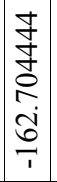 & 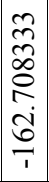 & $\begin{array}{l}\tilde{N} \\
\hat{a} \\
\hat{Q} \\
i \\
0 \\
1 \\
\end{array}$ & 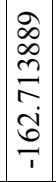 & 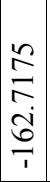 & 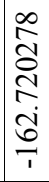 & 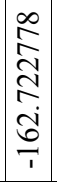 & 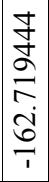 & 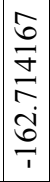 & 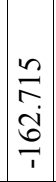 & 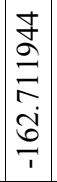 & $\mid \begin{array}{c} \\
\mathbb{N} \\
\mathrm{i} \\
\frac{1}{1} \\
\end{array}$ & 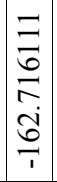 & 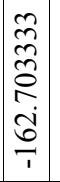 & 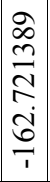 & 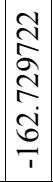 & 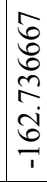 \\
\hline 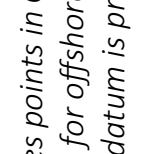 & 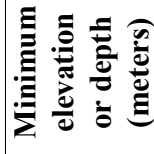 & & $\begin{array}{l}\infty \\
i \\
i\end{array}$ & $n$ & $?$ & $\stackrel{=}{I}$ & $\stackrel{n}{=}$ & $\vec{i}$ & \pm & $\mid \begin{array}{l}\infty \\
\stackrel{\sim}{\sim}\end{array}$ & $\ddot{n}$ & $\hat{i}$ & $\vec{\sim}$ & ت্் & $\frac{\partial}{\vec{\lambda}}$ & $\begin{array}{l}\ddot{n} \\
\ddot{n}\end{array}$ & $\vec{a}$ & $\stackrel{\substack{\sim \\
⿱ 亠 乂}}{ }$ & $\begin{array}{l}0 \\
\dot{d} \\
\dot{\sim}\end{array}$ & $\stackrel{?}{\stackrel{n}{N}}$ & $\mid \begin{array}{r}n \\
\stackrel{\sim}{\sim}\end{array}$ & $\stackrel{+}{\dot{\lambda}}$ & 2 \\
\hline & $\frac{0}{\infty}$ & 0 & 0 & $\infty$ & $\infty$ & $\infty$ & $\infty$ & os & us & is & $\infty$ & $\omega$ & $\infty$ & $\infty$ & $\infty$ & is & $\infty$ & $\infty$ & os & $\infty$ & $\infty$ & is & is \\
\hline 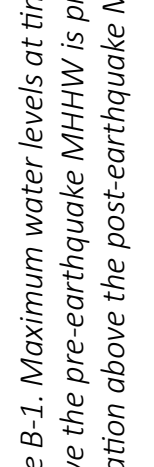 & $\begin{array}{l}\bar{\Xi} \\
\text { ఏ్త }\end{array}$ & $\begin{array}{l}\vec{\nexists} \\
0 \\
0 \\
0 \\
0\end{array}$ & $\mid \begin{array}{l}4 \\
0 \\
0 \\
\vdots \\
0 \\
0\end{array}$ & 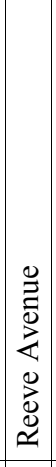 & 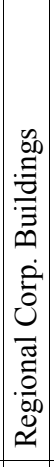 & 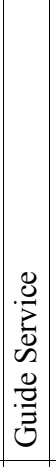 & 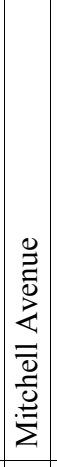 & 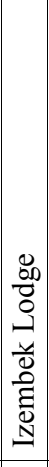 & 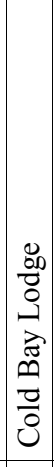 & 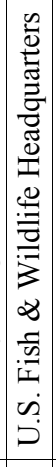 & 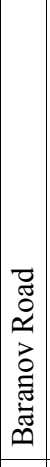 & 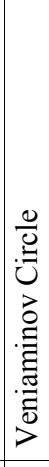 & 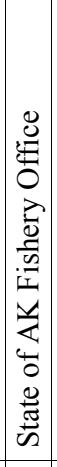 & 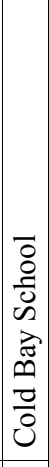 & 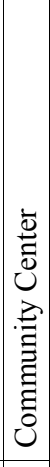 & 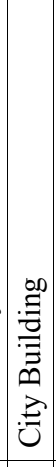 & 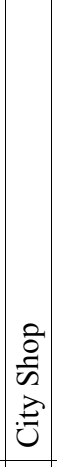 & 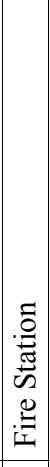 & 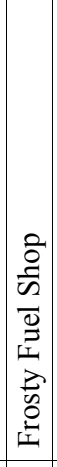 & 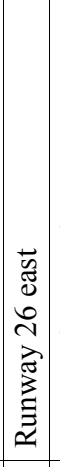 & 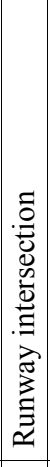 & 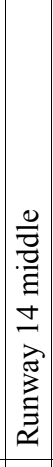 & 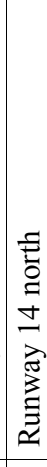 \\
\hline & $\#$ & - & $\sim$ & $m$ & $\nabla$ & $n$ & 0 & $r$ & $\infty$ & $a$ & 인 & $=$ & $\simeq$ & 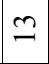 & \pm & $\because$ & 0 & $\Xi$ & $\stackrel{\infty}{-}$ & 2 & $\stackrel{\sim}{2}$ & $\vec{\sim}$ & त \\
\hline
\end{tabular}




\begin{tabular}{|c|c|c|c|c|c|c|c|c|c|c|c|c|c|c|c|c|c|c|c|c|c|c|c|}
\hline \multirow{16}{*}{ 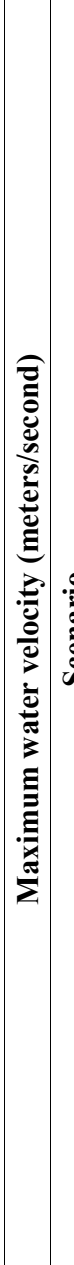 } & $\stackrel{\varrho}{0}$ & 3 & กֵ & 0 & 0 & 0 & 0 & 0 & 0 & 0 & 0 & 0 & 0 & 0 & 0 & 0 & 0 & 0 & 0 & 0 & 0 & 0 & 0 \\
\hline & 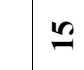 & ชุ & $\overrightarrow{0}$ & 0 & 0 & 0 & 0 & 0 & 0 & 0 & 0 & 0 & 0 & 0 & 0 & 0 & 0 & 0 & 0 & 0 & 0 & 0 & 0 \\
\hline & \pm & t. & กֵ & 0 & 0 & 0 & 0 & 0 & 0 & 0 & 0 & 0 & 0 & 0 & 0 & 0 & 0 & 0 & 0 & 0 & 0 & 0 & 0 \\
\hline & 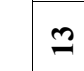 & $\stackrel{1}{\simeq}$ & $\exists$ & $\dot{m}$ & 0 & 0 & 0 & 0 & 0 & 0 & 0 & 0 & 0 & 0 & 0 & 0 & 0 & 0 & 0 & 0 & 0 & 0 & 0 \\
\hline & $\simeq$ & $\tilde{o}$ & $\tilde{0}$ & 0 & 0 & 0 & 0 & 0 & 0 & 0 & 0 & 0 & 0 & 0 & 0 & 0 & 0 & 0 & 0 & 0 & 0 & 0 & 0 \\
\hline & $=$ & $\stackrel{m}{-}$ & $\exists$ & $\stackrel{\vartheta}{\dot{\tau}}$ & 0 & 0 & 0 & 0 & 0 & 0 & 0 & 0 & 0 & 0 & 0 & 0 & 0 & 0 & 0 & 0 & 0 & 0 & 0 \\
\hline & $\varrho$ & $\because$ & - & $\vec{m}$ & 0 & 0 & 0 & 0 & 0 & 0 & 0 & 0 & 0 & 0 & 0 & 0 & 0 & 0 & 0 & 0 & 0 & 0 & 0 \\
\hline & $a$ & $\stackrel{\circ}{-}$ & ت & $\begin{array}{l}\infty \\
\dot{f}\end{array}$ & 0 & 0 & 0 & 0 & 0 & 0 & 0 & 0 & 0 & 0 & 0 & 0 & 0 & 0 & 0 & 0 & 0 & 0 & 0 \\
\hline & \begin{tabular}{c|l}
$\overline{\bar{u}}$ \\
$\tilde{n}$
\end{tabular} & $\stackrel{\infty}{-}$ & $\stackrel{\infty}{-}$ & $\begin{array}{l}\vec{r} \\
\ddot{r}\end{array}$ & 0 & 0 & 0 & 0 & 0 & 0 & 0 & 0 & 0 & 0 & 0 & 0 & 0 & 0 & 0 & 0 & 0 & 0 & 0 \\
\hline & $r$ & $\stackrel{\sim}{i}$ & $\stackrel{n}{-}$ & $\dot{m}$ & 0 & 0 & 0 & 0 & 0 & 0 & 0 & 0 & 0 & 0 & 0 & 0 & 0 & 0 & 0 & 0 & 0 & 0 & 0 \\
\hline & b & $\tilde{o}$ & o: & 0 & 0 & 0 & 0 & 0 & 0 & 0 & 0 & 0 & 0 & 0 & 0 & 0 & 0 & 0 & 0 & 0 & 0 & 0 & 0 \\
\hline & in & $\ddot{0}$ & ? & 0 & 0 & 0 & 0 & 0 & 0 & 0 & 0 & 0 & 0 & 0 & 0 & 0 & 0 & 0 & 0 & 0 & 0 & 0 & 0 \\
\hline & $\nabla$ & $\begin{array}{l}\infty \\
0 \\
0\end{array}$ & $\stackrel{0}{0}$ & $\ddot{n}$ & 0 & 0 & 0 & 0 & 0 & 0 & 0 & 0 & 0 & 0 & 0 & 0 & 0 & 0 & 0 & 0 & 0 & 0 & 0 \\
\hline & $m$ & - & $\stackrel{\infty}{0}$ & $\vec{r}$ & 0 & 0 & 0 & 0 & 0 & 0 & 0 & 0 & 0 & 0 & 0 & 0 & 0 & 0 & 0 & 0 & 0 & 0 & 0 \\
\hline & $N$ & $\stackrel{m}{-}$ & $\stackrel{\text { I }}{-}$ & $\stackrel{m}{+}$ & 0 & 0 & 0 & 0 & 0 & 0 & 0 & 0 & 0 & 0 & 0 & 0 & 0 & 0 & 0 & 0 & 0 & 0 & 0 \\
\hline & - & $\stackrel{\text { I }}{-}$ & $\hat{0}$ & $\ddot{\dot{m}}$ & 0 & 0 & 0 & 0 & 0 & 0 & 0 & 0 & 0 & 0 & 0 & 0 & 0 & 0 & 0 & 0 & 0 & 0 & 0 \\
\hline \multicolumn{2}{|c|}{ 总 } & 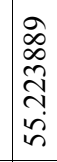 & $\begin{array}{l}1 \\
6 \\
0 \\
0 \\
N \\
i \\
i n\end{array}$ & $\begin{array}{l}2 \\
2 \\
2 n \\
n\end{array}$ & 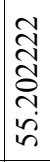 & $\begin{array}{l}\infty \\
\hat{\infty} \\
\infty \\
o \\
i \\
i n \\
i n\end{array}$ & 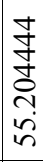 & $\begin{array}{l}\exists \\
\overline{7} \\
0 \\
n \\
i n \\
n \\
n\end{array}$ & $\begin{array}{l} \\
i \\
i \\
i \\
i n \\
i n\end{array}$ & 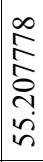 & 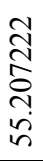 & 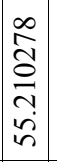 & $\begin{array}{l}0 \\
2 \\
n \\
0 \\
n \\
n \\
n \\
n\end{array}$ & 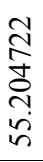 & 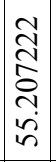 & 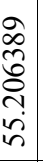 & $\begin{array}{l}- \\
\vdots \\
0 \\
0 \\
i \\
i \\
n \\
n\end{array}$ & 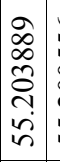 & 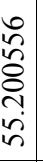 & 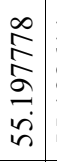 & $\begin{array}{l}\exists \\
\overrightarrow{0} \\
2 \\
2 \\
\dot{1} \\
i n\end{array}$ & 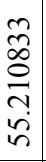 & $\begin{array}{l}\exists \\
\equiv \\
\overline{\bar{N}} \\
i \\
n \\
i n\end{array}$ \\
\hline \multicolumn{2}{|c|}{ 总产 } & 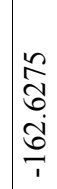 & $\begin{array}{l}n \\
\hat{o} \\
i \\
6 \\
1\end{array}$ & 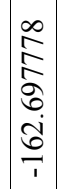 & $\begin{array}{l}\hat{b} \\
0 \\
2 \\
i \\
i \\
1 \\
1\end{array}$ & 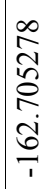 & $\begin{array}{l}\frac{8}{J} \\
\text { d } \\
\stackrel{2}{i} \\
\text { d } \\
1\end{array}$ & 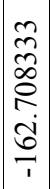 & 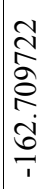 & 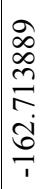 & 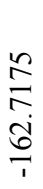 & 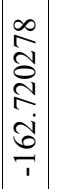 & 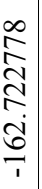 & 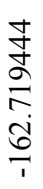 & 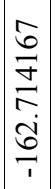 & 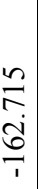 & 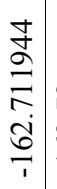 & 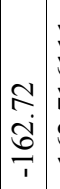 & 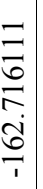 & $\begin{array}{l}m \\
\hat{n} \\
\hat{n} \\
\hat{i} \\
0 \\
1\end{array}$ & 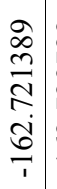 & 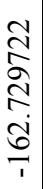 & 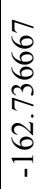 \\
\hline \multicolumn{2}{|c|}{ 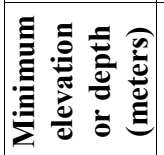 } & & $\begin{array}{l}\infty \\
\stackrel{\mathfrak{I}}{ }\end{array}$ & $\because$ & $\stackrel{?}{r}$ & $\stackrel{1}{I}$ & $\stackrel{n}{=}$ & $\vec{i}$ & \pm & $\begin{array}{l}\infty \\
\stackrel{+}{d}\end{array}$ & $\ddot{\ddot{g}}$ & $\hat{\stackrel{i}{~}}$ & $\vec{\sim}$ & $\overrightarrow{\dot{d}}$ & $\frac{a}{\vec{v}}$ & $\stackrel{t}{\grave{d}}$ & $\vec{a}$ & $\stackrel{\stackrel{\sim}{\perp}}{\stackrel{\sim}{\sim}}$ & $\begin{array}{l}\overrightarrow{0} \\
\stackrel{\sim}{\mathrm{d}}\end{array}$ & $\stackrel{?}{\stackrel{n}{\sim}}$ & $\stackrel{\sim}{\stackrel{\sim}{\sim}}$ & & 9 \\
\hline \multicolumn{2}{|c|}{$n-0$} & 0 & 0 & $\infty$ & $\infty$ & os & is & os & es & is & $\sim$ & $\infty$ & $n$ & $n$ & $n$ & $n$ & os & es & $n$ & $n$ & is & $\infty$ & is \\
\hline \multicolumn{2}{|r|}{ 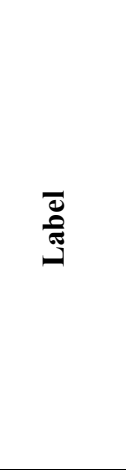 } & $\begin{array}{l}\vec{\nexists} \\
\underline{0} \\
\overrightarrow{0} \\
0\end{array}$ & 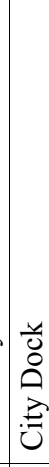 & 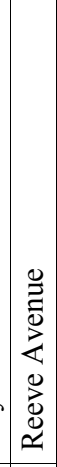 & 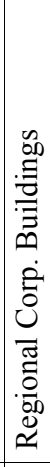 & 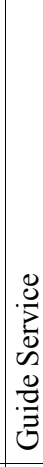 & 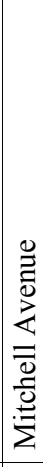 & 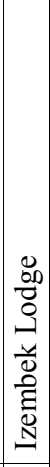 & 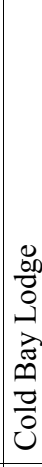 & 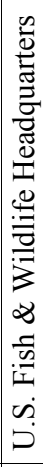 & 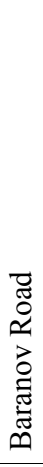 & 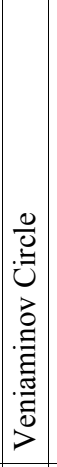 & 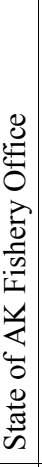 & 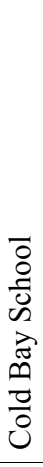 & 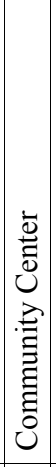 & 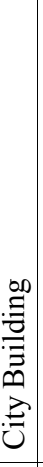 & 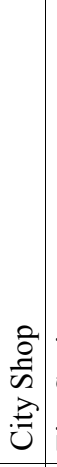 & 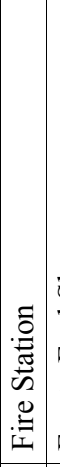 & 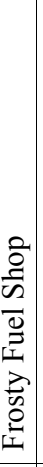 & 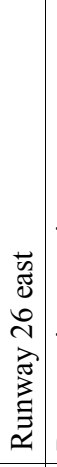 & 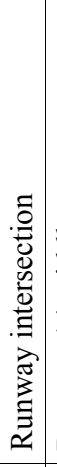 & 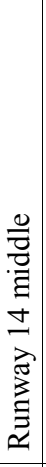 & 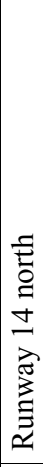 \\
\hline \multicolumn{2}{|r|}{ \# } & - & $v$ & $n$ & $\theta$ & in & 0 & $r$ & $\infty$ & $a$ & 으 & $=$ & $\simeq$ & 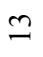 & $\Xi$ & 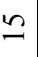 & 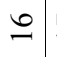 & 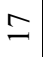 & $\infty$ & $\approx$ & $\stackrel{i}{\sim}$ & $\vec{\sim}$ & ป \\
\hline
\end{tabular}



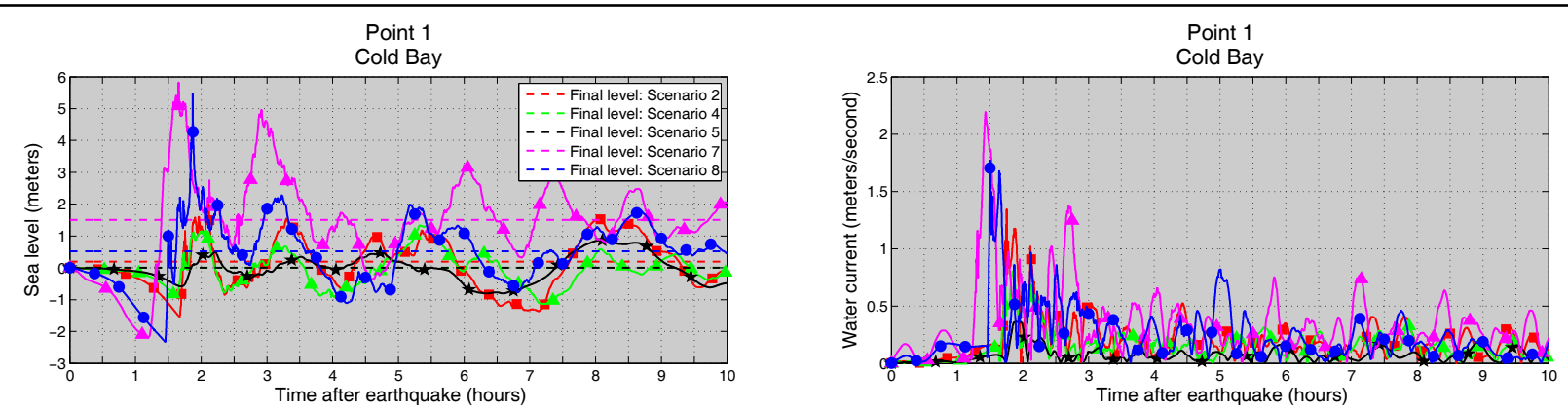

Pre-earthquake depth $22.6 \mathrm{~m}(74.3 \mathrm{ft})$

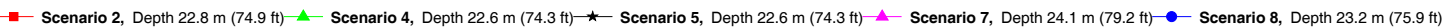
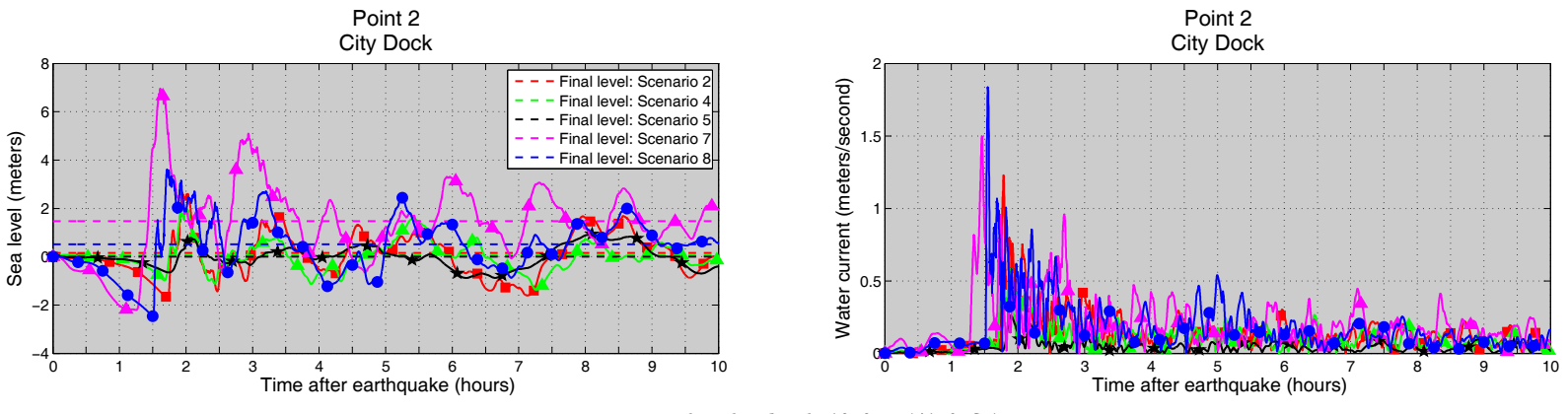

Pre-earthquake depth $12.8 \mathrm{~m}(41.9 \mathrm{ft})$

- Scenario 2, Depth $12.9 \mathrm{~m}(42.4 \mathrm{ft}) \_$Scenario 4, Depth $12.8 \mathrm{~m}(42.1 \mathrm{ft})$ « Scenario 5, Depth $12.8 \mathrm{~m}(41.9 \mathrm{ft}) \_$Scenario 7 , Depth $14.2 \mathrm{~m}(46.7 \mathrm{ft})-$ Scenario 8 , Depth $13.3 \mathrm{~m}(43.6 \mathrm{ft})$
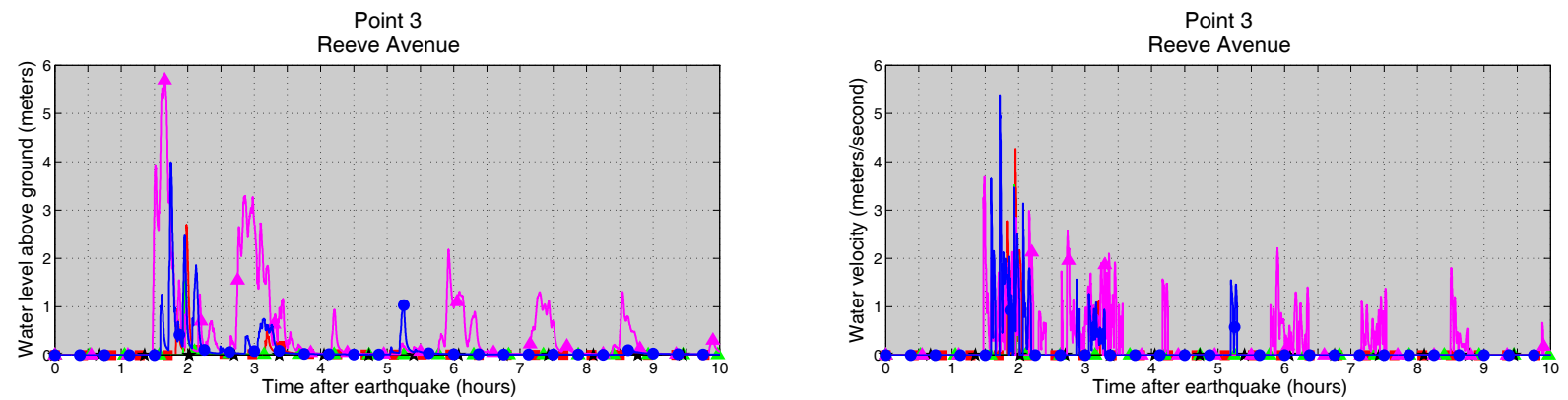

Pre-earthquake elevation $2.0 \mathrm{~m}(6.5 \mathrm{ft}$

- Scenario 2, Elevation $1.8 \mathrm{~m}(6.0 \mathrm{ft})-$ Scenario 4, Elevation $1.9 \mathrm{~m}(6.4 \mathrm{ft}) \star$ « Scenario 5, Elevation $2.0 \mathrm{~m}(6.5 \mathrm{ft})-$ Scenario 7 , Elevation $0.5 \mathrm{~m}(1.6 \mathrm{ft})-$ Scenario 8 , Elevation $1.5 \mathrm{~m}(4.8 \mathrm{ft})$

Point 4

Regional Corp. Buildings

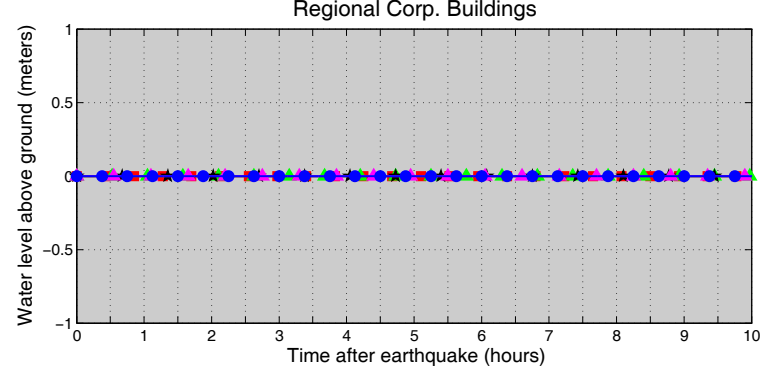

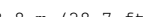

Point 4

Regional Corp. Buildings

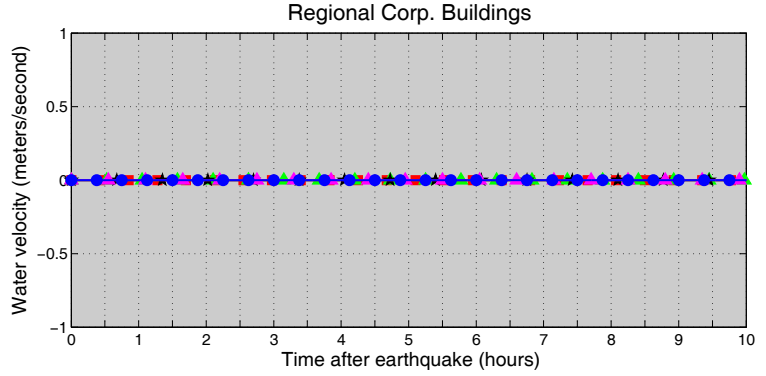

$\rightarrow$ Scenario 2, Elevation $8.6 \mathrm{~m}(28.2 \mathrm{ft}) \leadsto$ Scenario 4, Elevation $8.7 \mathrm{~m}(28.6 \mathrm{ft})-$ Scenario 5 , Elevation $8.8 \mathrm{~m}(28.7 \mathrm{ft})-$ Scenario 7 , Elevation $7.3 \mathrm{~m}(23.9 \mathrm{ft})-$ Scenario 8 , Elevation $8.3 \mathrm{~m}(27.1 \mathrm{ft})$

Figure B-2. Graphs showing time series of water level (left column) and velocity (right column) for selected locations in Cold Bay for scenarios 2, 4, 5, 7 and 8. For each location, pre-earthquake and post-earthquake elevation/depth corresponding to the MHHW datum is provided for each scenario. For offshore locations, to show the height of an arriving tsunami, the vertical datum is such that zero corresponds to the pre-earthquake sea level. Dashed lines show the water level after the tsunami. 

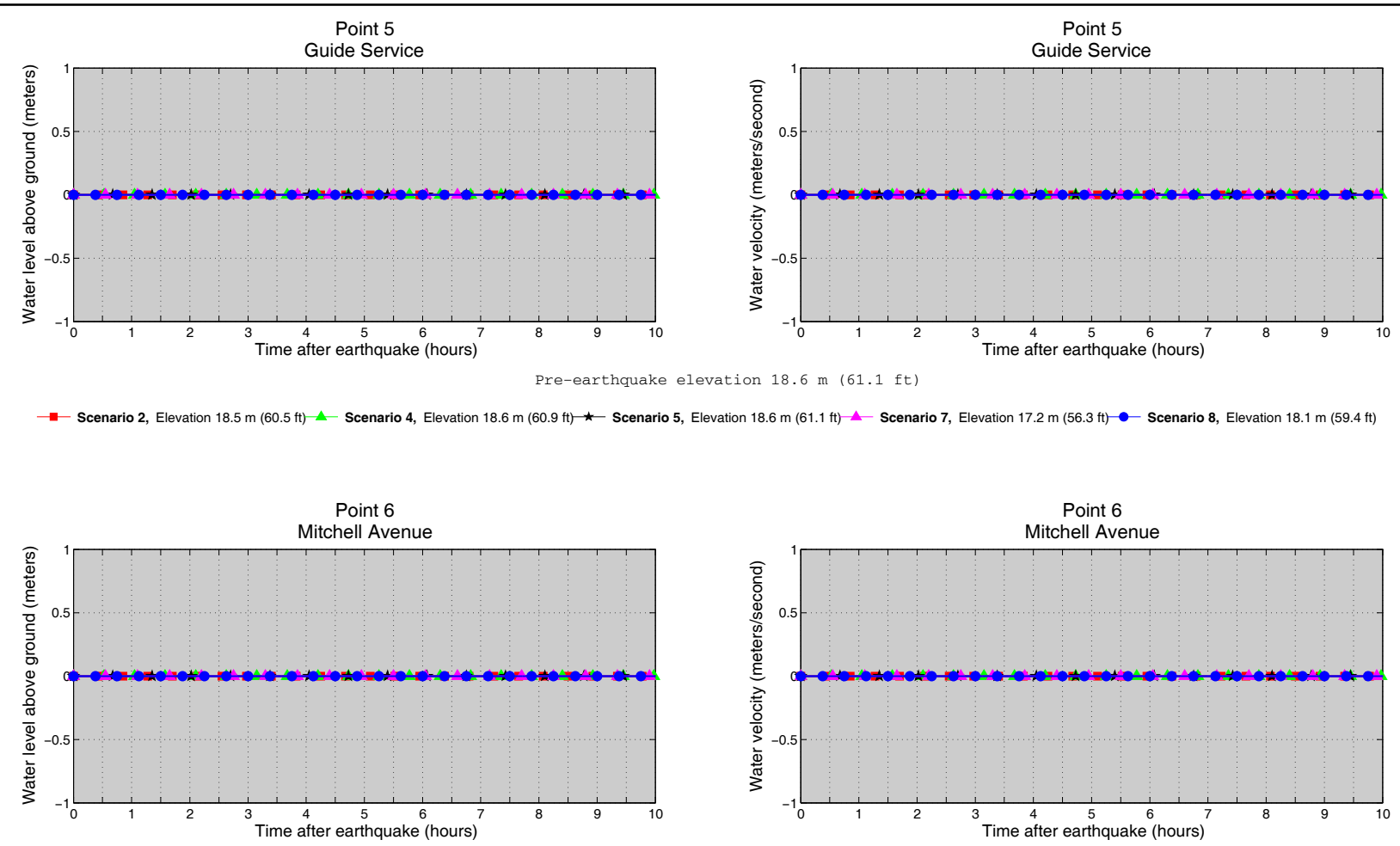

Pre-earthquake elevation $13.0 \mathrm{~m}(42.6 \mathrm{ft})$

$\rightarrow$ Scenario 2, Elevation $12.8 \mathrm{~m}(42.1 \mathrm{ft})-$ Scenario 4, Elevation $12.9 \mathrm{~m}(42.4 \mathrm{ft}) \longleftarrow$ Scenario 5 , Elevation $13.0 \mathrm{~m}(42.6 \mathrm{ft})-$ Scenario 7 , Elevation $11.5 \mathrm{~m}(37.8 \mathrm{ft})-$ Scenario 8 , Elevation $12.5 \mathrm{~m}(40.9 \mathrm{ft})$
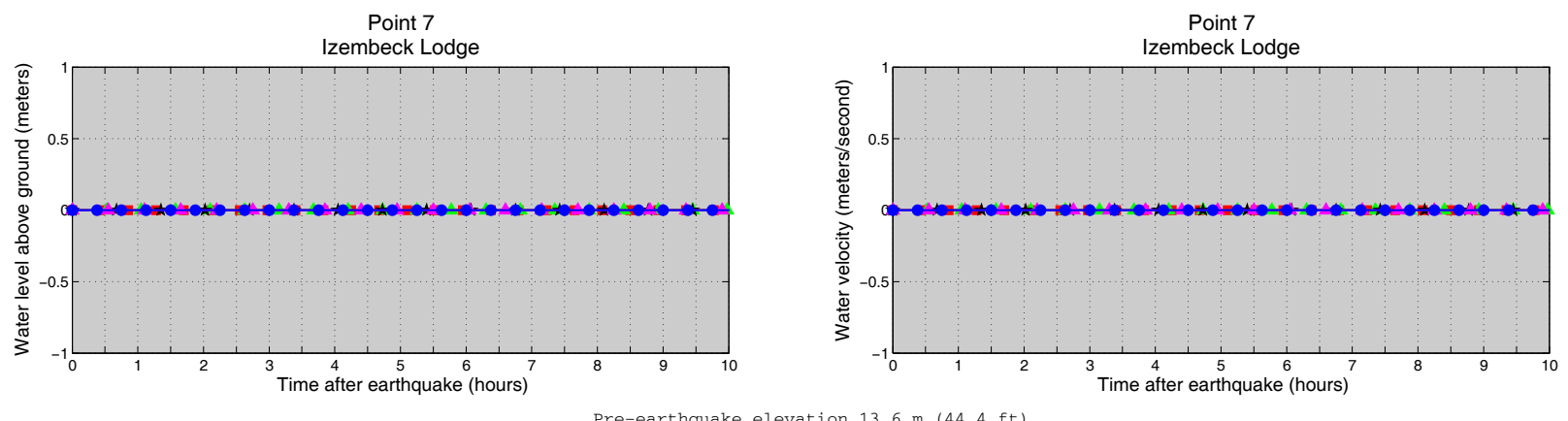

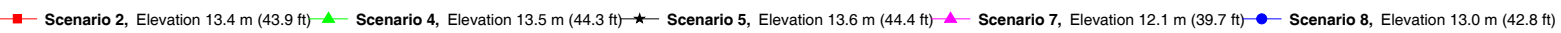
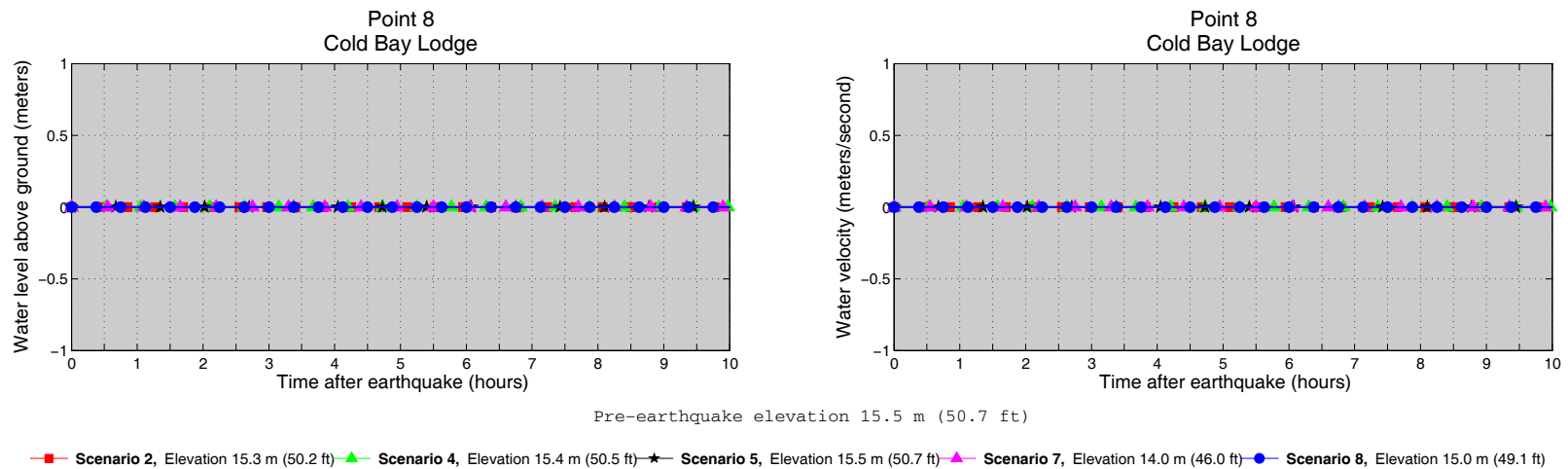

Figure B-2 (cont.). Graphs showing time series of water level (left column) and velocity (right column) for selected locations in Cold Bay for scenarios 2, 4, 5, 7 and 8. For each location, pre-earthquake and post-earthquake elevation/depth corresponding to the MHHW datum is provided for each scenario. For offshore locations, to show the height of an arriving tsunami, the vertical datum is such that zero corresponds to the pre-earthquake sea level. Dashed lines show the water level after the tsunami. 

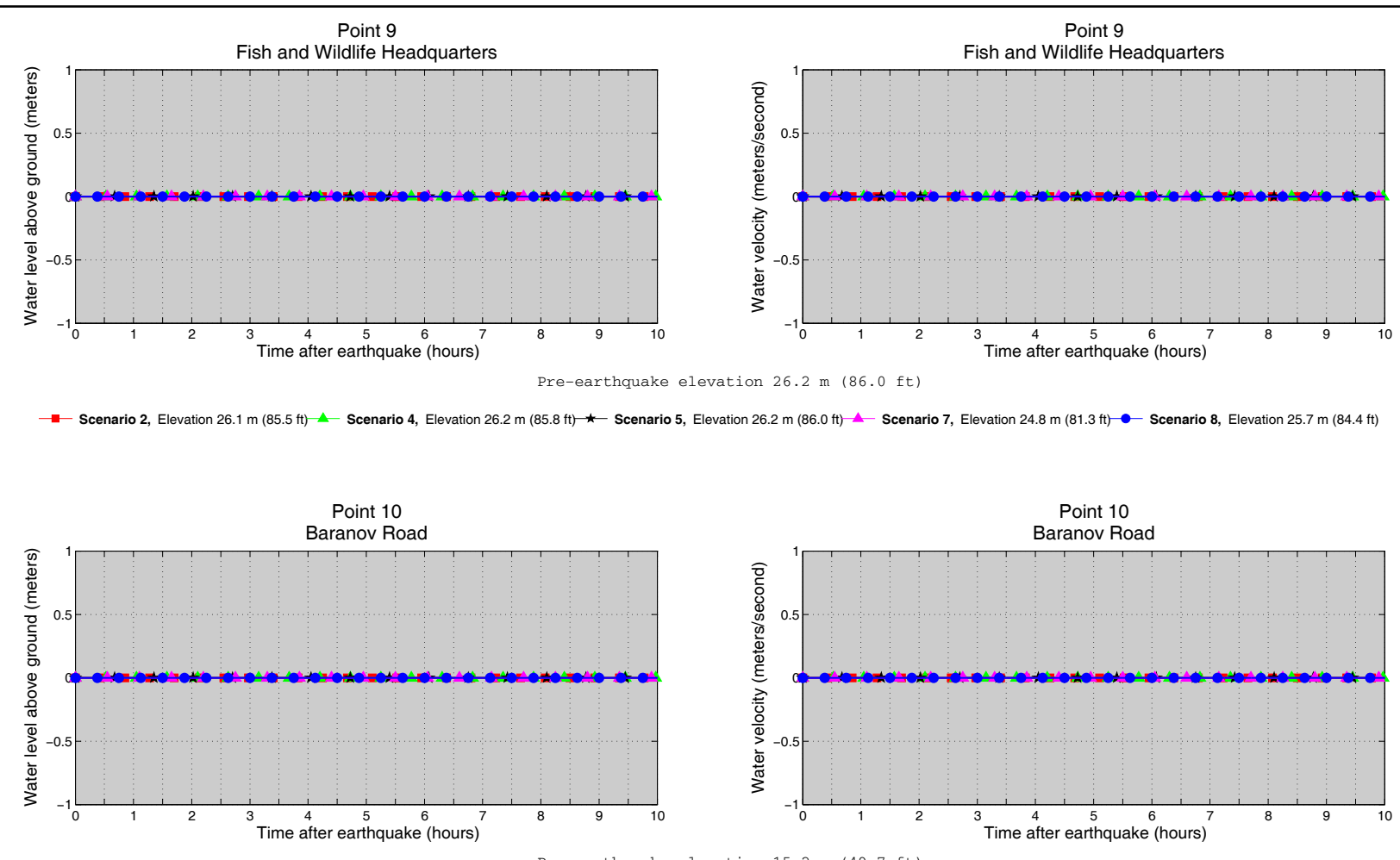

Pre-earthquake elevation $15.2 \mathrm{~m}(49.7 \mathrm{ft})$

- Scenario 2, Elevation $15.0 \mathrm{~m}(49.2 \mathrm{ft}) \_$Scenario 4, Elevation $15.1 \mathrm{~m}(49.6 \mathrm{ft}) \star$ Scenario 5 , Elevation $15.2 \mathrm{~m}(49.7 \mathrm{ft})-$ Scenario 7 , Elevation $13.7 \mathrm{~m}(45.0 \mathrm{ft})-$ Scenario 8 , Elevation $14.7 \mathrm{~m}(48.1 \mathrm{ft})$

Point 11

Veniaminov Circle

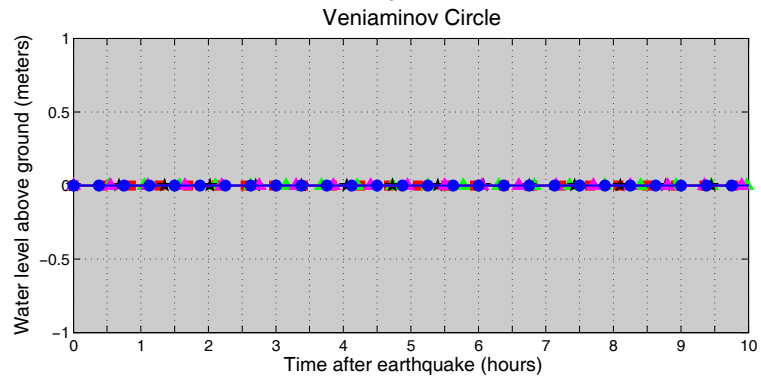

Pre-earthquake elevation $22.1 \mathrm{~m}(72.5 \mathrm{ft})$

Point 11

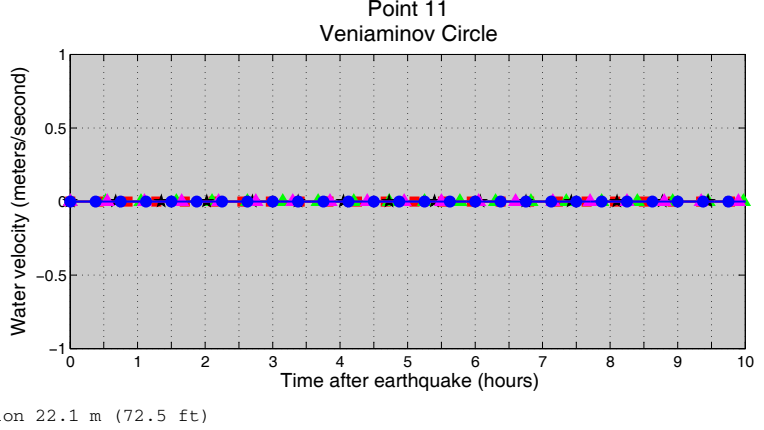

Point 12

State of AK Fishery Office

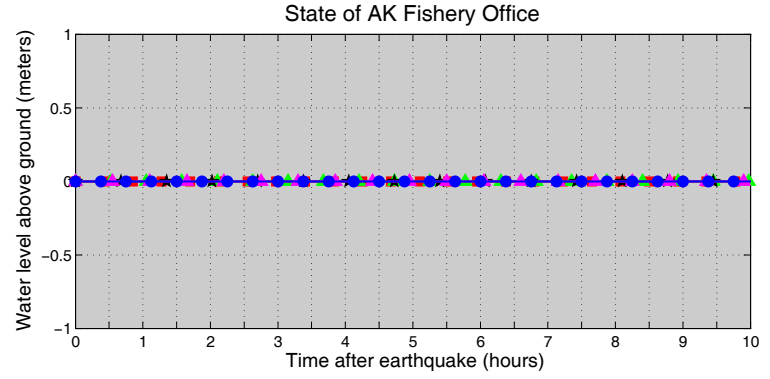

Point 12

State of AK Fishery Office

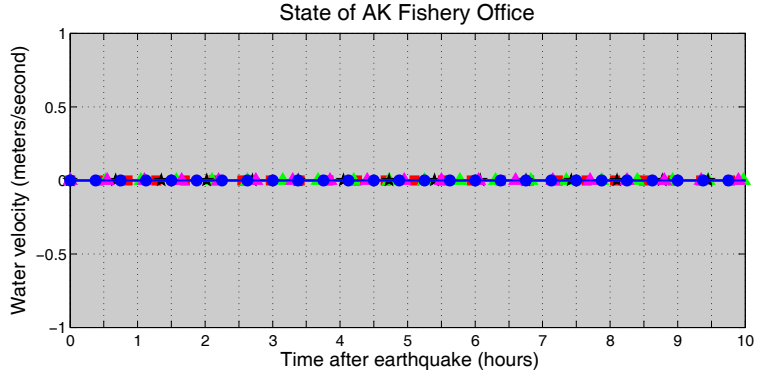

Pre-earthquake elevation $22.4 \mathrm{~m}(73.4 \mathrm{ft})$

- Scenario 2, Elevation $22.2 \mathrm{~m}(72.9 \mathrm{ft})-$ Scenario 4, Elevation $22.3 \mathrm{~m}(73.2 \mathrm{ft})$ « Scenario 5, Elevation $22.4 \mathrm{~m}(73.4 \mathrm{ft})-$ Scenario 7 , Elevation $21.0 \mathrm{~m}(68.7 \mathrm{ft})-$ - Scenario 8 , Elevation $21.9 \mathrm{~m}(71.8 \mathrm{ft})$

Figure B-2 (cont.). Graphs showing time series of water level (left column) and velocity (right column) for selected locations in Cold Bay for scenarios 2, 4, 5, 7 and 8. For each location, pre-earthquake and post-earthquake elevation/depth corresponding to the MHHW datum is provided for each scenario. For offshore locations, to show the height of an arriving tsunami, the vertical datum is such that zero corresponds to the pre-earthquake sea level. Dashed lines show the water level after the tsunami. 

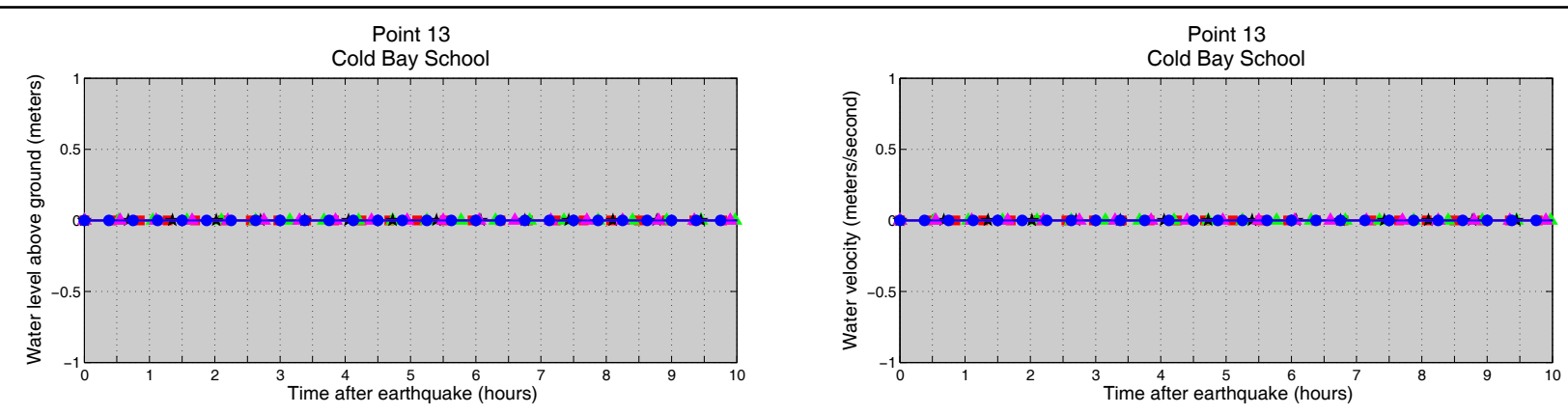

Pre-earthquake elevation $25.5 \mathrm{~m}(83.7 \mathrm{ft})$

- Scenario 2, Elevation $25.4 \mathrm{~m}(83.2 \mathrm{ft}) \_$- Scenario 4, Elevation $25.5 \mathrm{~m}(83.5 \mathrm{ft}) \_$- Scenario 5, Elevation $25.5 \mathrm{~m}(83.7 \mathrm{ft})-$ Scenario 7 , Elevation $24.1 \mathrm{~m}(79.0 \mathrm{ft})-$ Scenario 8 , Elevation $25.0 \mathrm{~m}(82.0 \mathrm{ft})$
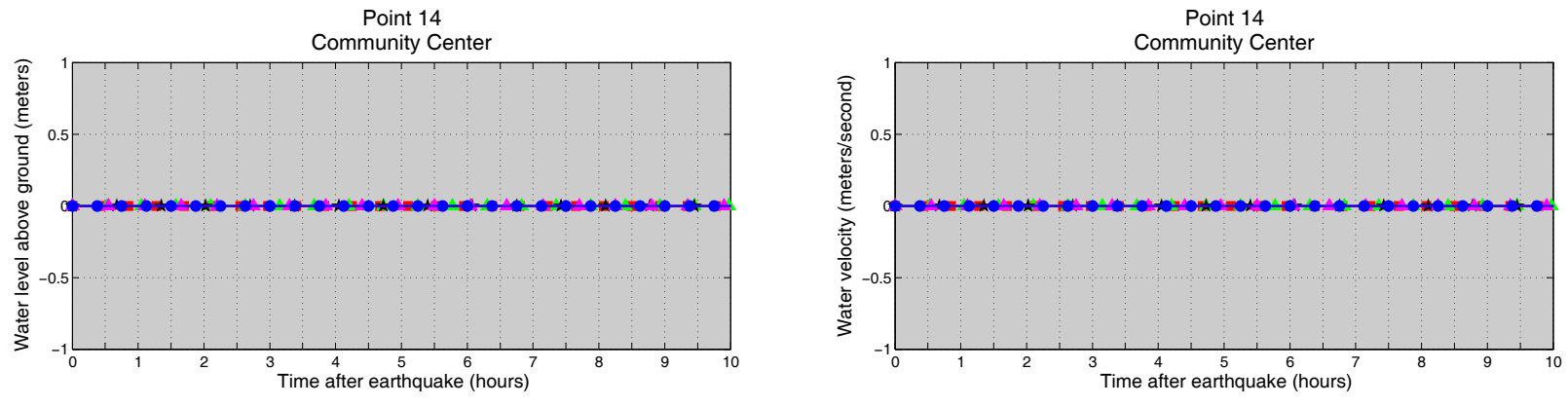

Pre-earthquake elevation $23.4 \mathrm{~m}(76.6 \mathrm{ft})$

$\rightarrow$ Scenario 2, Elevation $23.2 \mathrm{~m}(76.1 \mathrm{ft}) \_$Scenario 4, Elevation $23.3 \mathrm{~m}(76.5 \mathrm{ft}) \star$ Scenario 5, Elevation $23.4 \mathrm{~m}(76.6 \mathrm{ft}) \_$Scenario 7 , Elevation $21.9 \mathrm{~m}(71.9 \mathrm{ft})-$ Scenario 8 , Elevation $22.9 \mathrm{~m}(75.0 \mathrm{ft})$
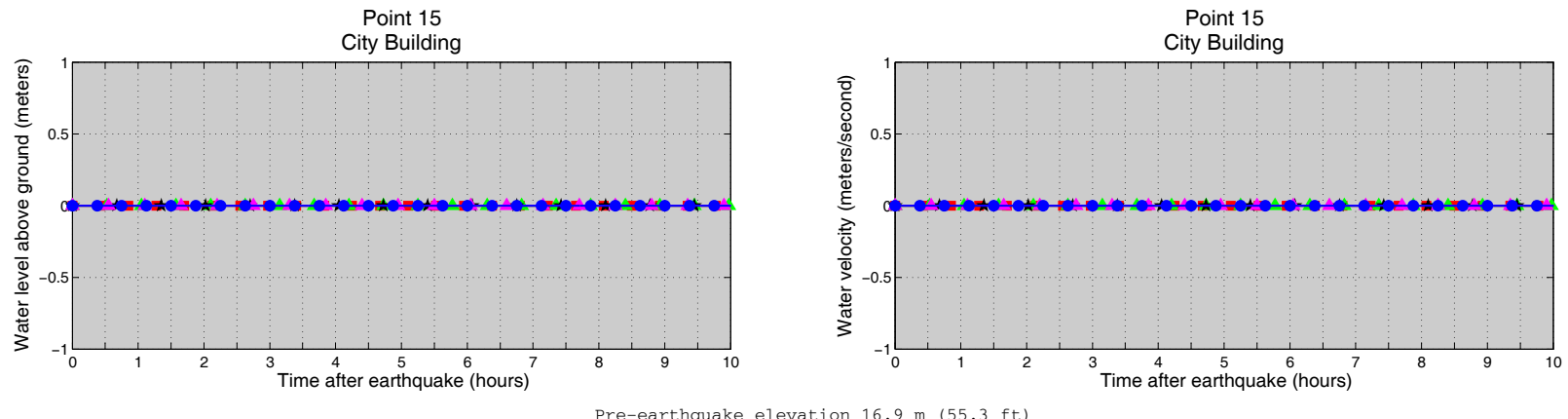

Pre-earthquake elevation $16.9 \mathrm{~m}(55.3 \mathrm{ft})$

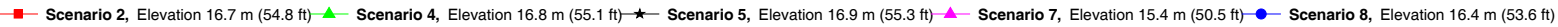
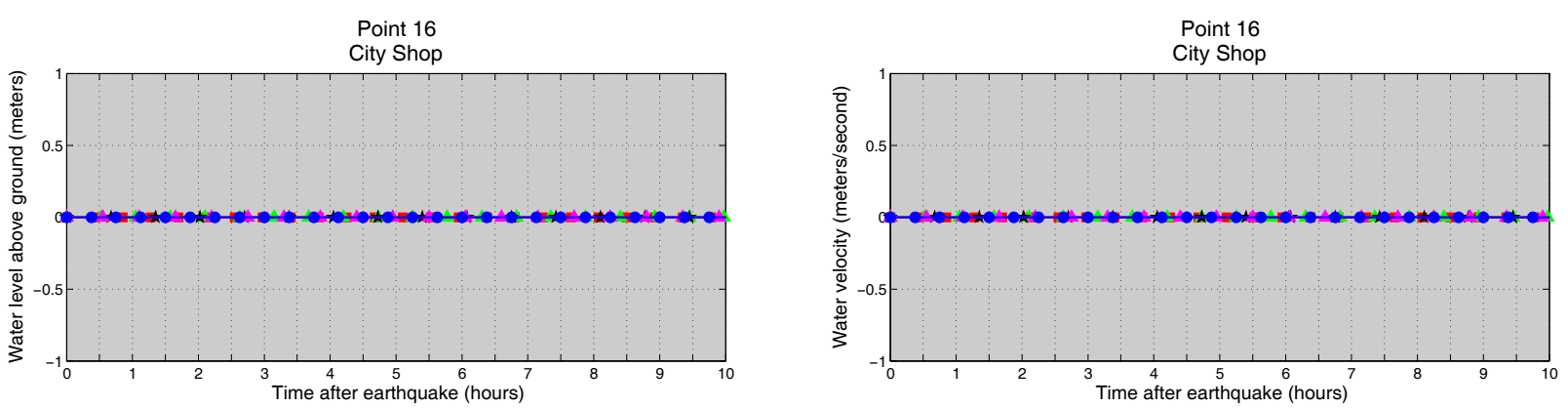

Pre-earthquake elevation $20.5 \mathrm{~m}(67.3 \mathrm{ft})$

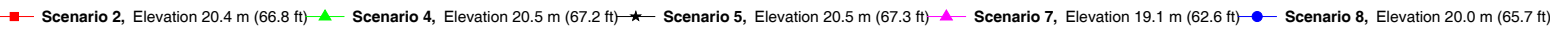

Figure B-2 (cont.). Graphs showing time series of water level (left column) and velocity (right column) for selected locations in Cold Bay for scenarios 2, 4, 5, 7 and 8. For each location, pre-earthquake and post-earthquake elevation/depth corresponding to the MHHW datum is provided for each scenario. For offshore locations, to show the height of an arriving tsunami, the vertical datum is such that zero corresponds to the pre-earthquake sea level. Dashed lines show the water level after the tsunami. 

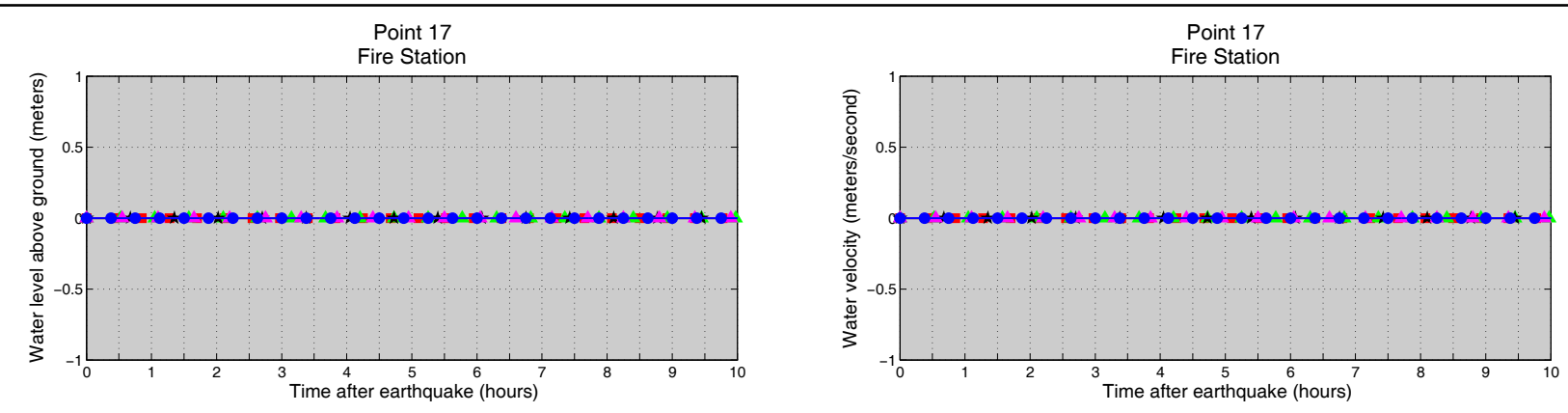

Pre-earthquake elevation $25.7 \mathrm{~m}(84.2 \mathrm{ft})$

- Scenario 2, Elevation $25.5 \mathrm{~m}(83.6 \mathrm{ft})-$ Scenario 4, Elevation $25.6 \mathrm{~m}(84.0 \mathrm{ft}) \multimap$ Scenario 5 , Elevation $25.7 \mathrm{~m}(84.2 \mathrm{ft})-$ Scenario 7 , Elevation $24.2 \mathrm{~m}(79.4 \mathrm{ft})-$ Scenario 8 , Elevation $25.2 \mathrm{~m}(82.5 \mathrm{ft})$
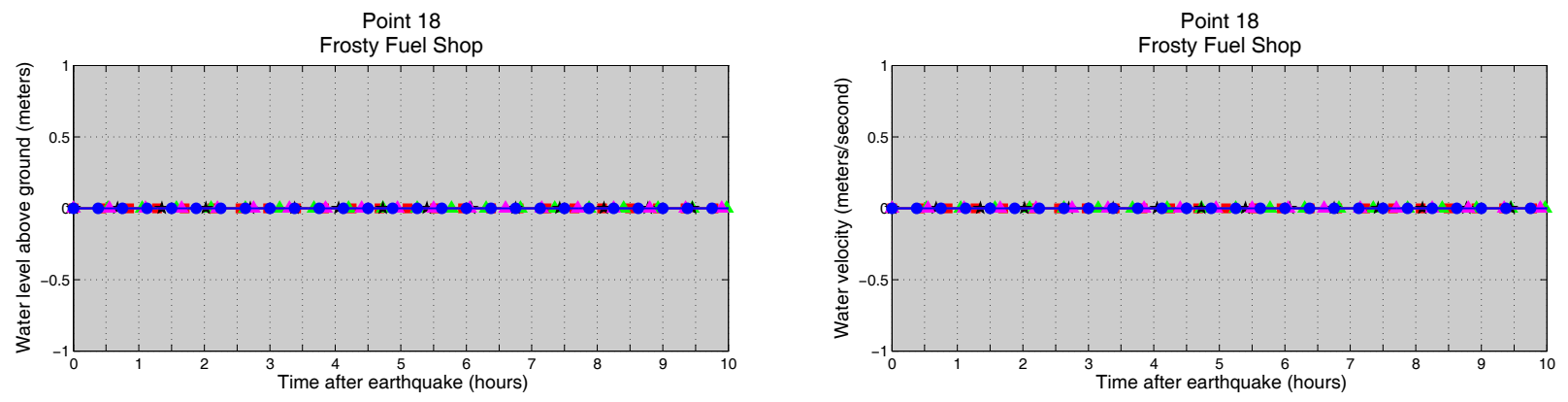

Pre-earthquake elevation $26.1 \mathrm{~m}(85.5 \mathrm{ft})$

- Scenario 2, Elevation $25.9 \mathrm{~m}(84.9 \mathrm{ft}) \backsim$ Scenario 4, Elevation $26.0 \mathrm{~m}(85.3 \mathrm{ft})$ — Scenario 5, Elevation $26.1 \mathrm{~m}(85.5 \mathrm{ft})-$ — Scenario 7 , Elevation $24.6 \mathrm{~m}(80.7 \mathrm{ft})-$ Scenario 8 , Elevation $25.6 \mathrm{~m}(83.8 \mathrm{ft})$

Point 19

Runway 26 east

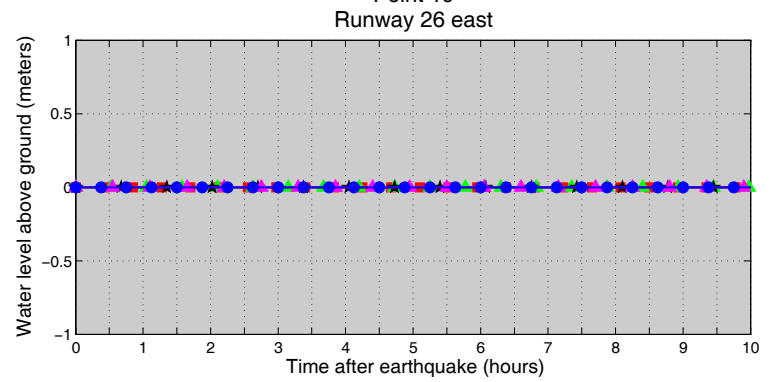

Pre-earthquake elevation $28.8 \mathrm{~m}(94.5 \mathrm{ft})$
Point 19

Runway 26 east

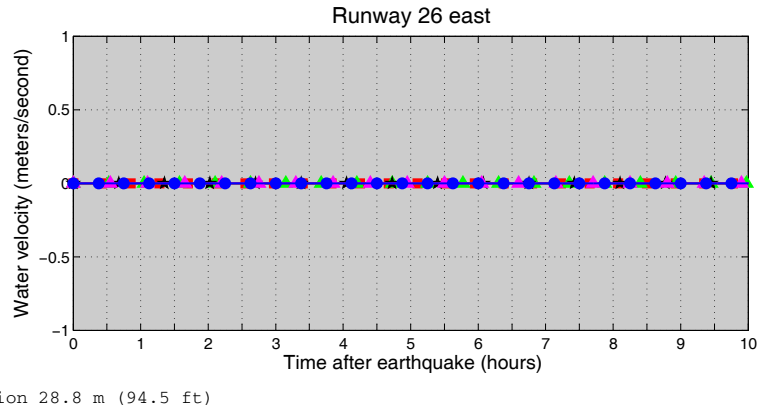

- Scenario 8, Elevation $28.3 \mathrm{~m}(92.8 \mathrm{ft})$

Point 20

Runway intersection

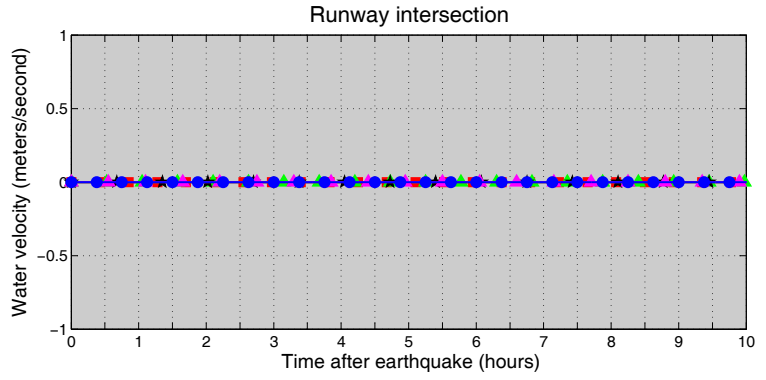

Pre-earthquake elevation $26.0 \mathrm{~m}(85.1 \mathrm{ft})$

- Scenario 2, Elevation $25.8 \mathrm{~m}(84.6 \mathrm{ft})-$ Scenario 4, Elevation $25.9 \mathrm{~m}(84.9 \mathrm{ft})$ « Scenario 5, Elevation $26.0 \mathrm{~m}(85.1 \mathrm{ft}) \backsim$ Scenario 7 , Elevation $24.5 \mathrm{~m}(80.3 \mathrm{ft})-$ Scenario 8 , Elevation $25.5 \mathrm{~m}(83.5 \mathrm{ft})$

Figure B-2 (cont.). Graphs showing time series of water level (left column) and velocity (right column) for selected locations in Cold Bay for scenarios 2, 4, 5, 7 and 8. For each location, pre-earthquake and post-earthquake elevation/depth corresponding to the MHHW datum is provided for each scenario. For offshore locations, to show the height of an arriving tsunami, the vertical datum is such that zero corresponds to the pre-earthquake sea level. Dashed lines show the water level after the tsunami. 


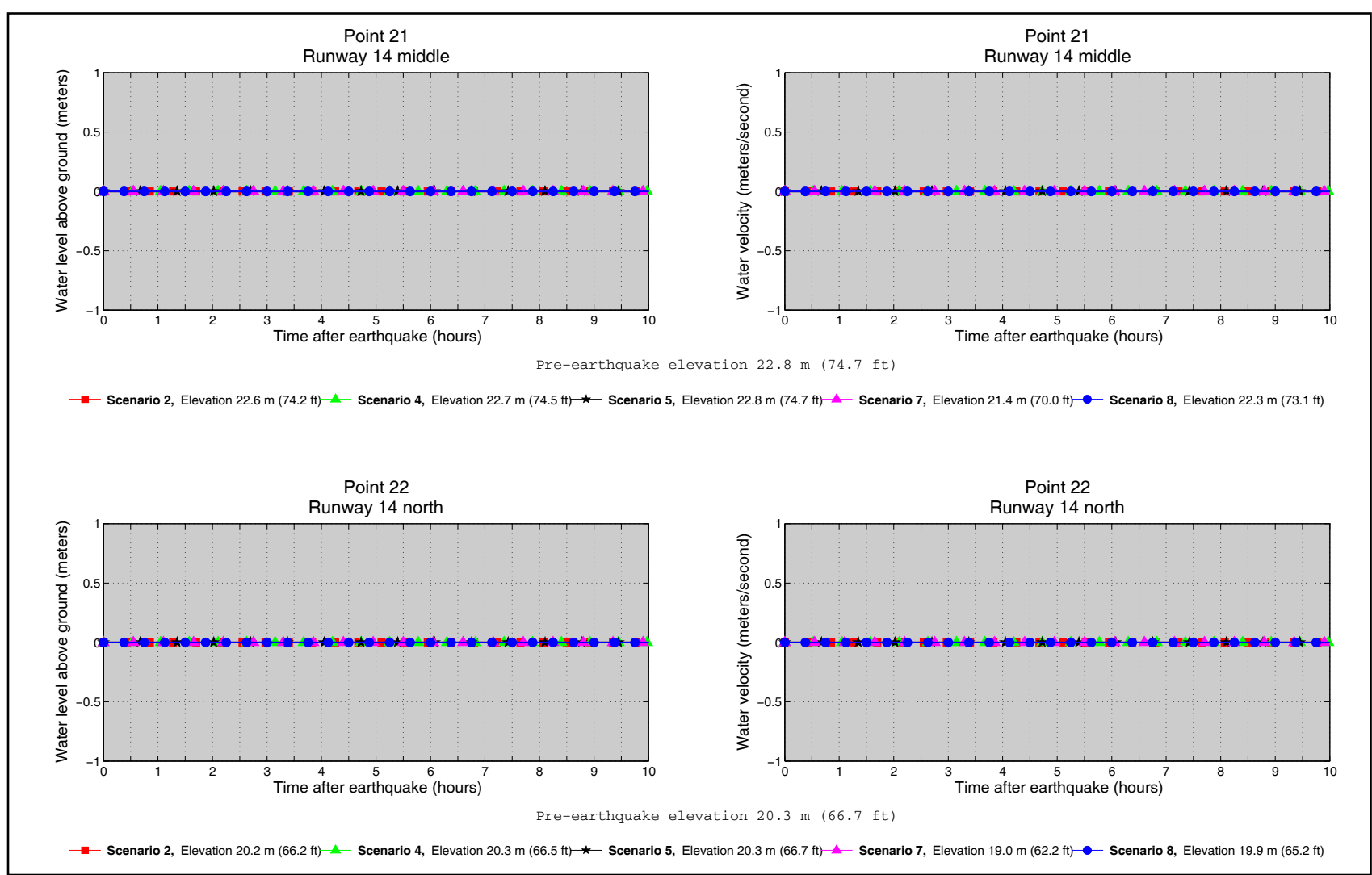

Figure B-2 (cont.). Graphs showing time series of water level (left column) and velocity (right column) for selected locations in Cold Bay for scenarios 2, 4, 5, 7 and 8. For each location, pre-earthquake and post-earthquake elevation/depth corresponding to the MHHW datum is provided for each scenario. For offshore locations, to show the height of an arriving tsunami, the vertical datum is such that zero corresponds to the pre-earthquake sea level. Dashed lines show the water level after the tsunami. 

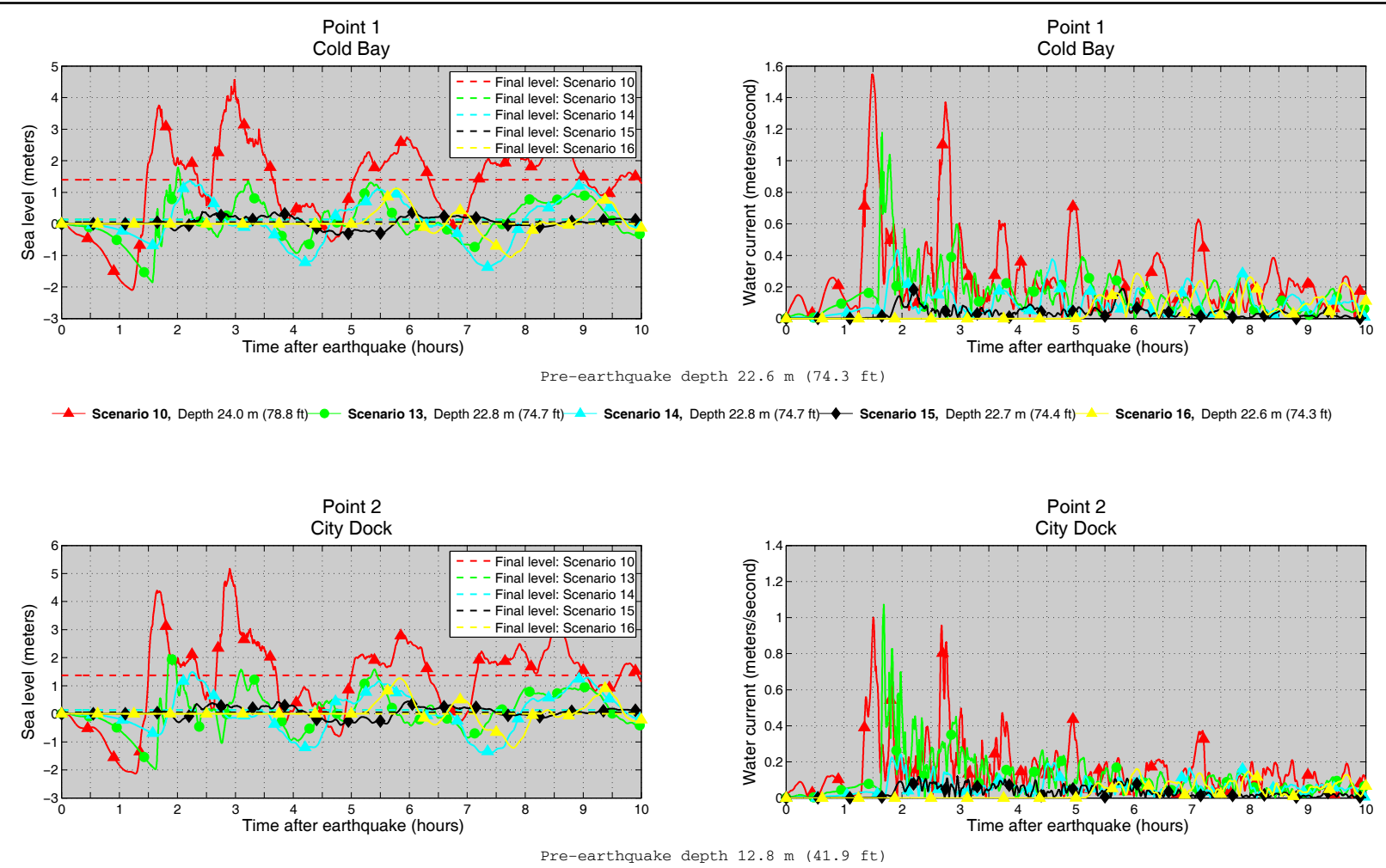

— Scenario 10, Depth $14.1 \mathrm{~m}(46.4 \mathrm{ft}) \smile$ Scenario 13, Depth $12.9 \mathrm{~m}(42.3 \mathrm{ft}) \backsim$ Scenario 14, Depth $12.9 \mathrm{~m}(42.3 \mathrm{ft}) \multimap-$ Scenario 15, Depth $12.8 \mathrm{~m}(42.1 \mathrm{ft})-$ Scenario 16, Depth $12.8 \mathrm{~m}(41.9 \mathrm{ft})$
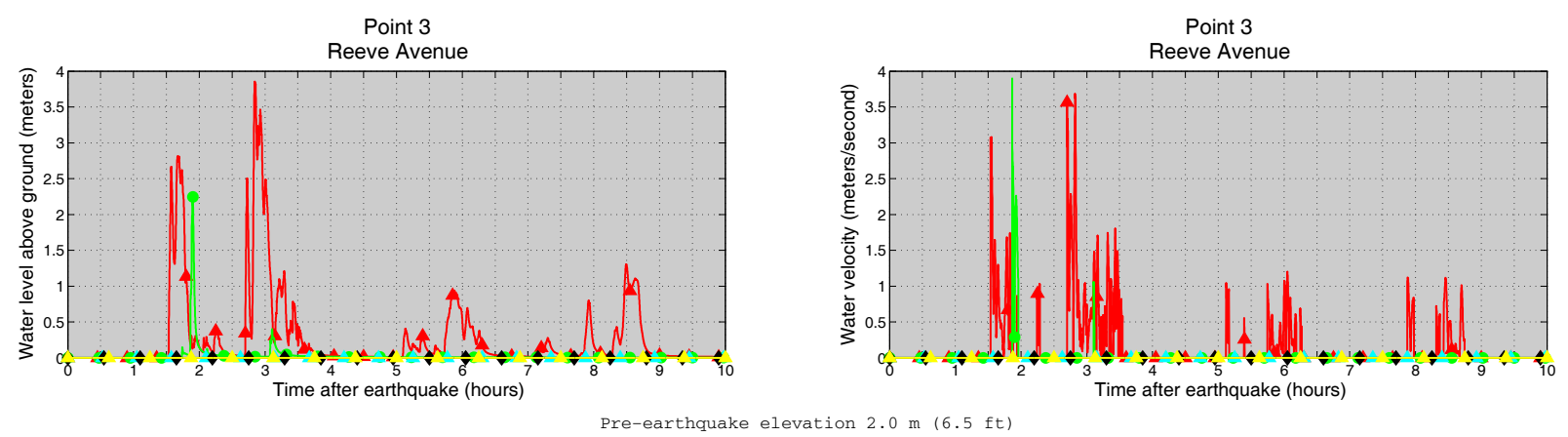

- Scenario 10, Elevation $0.6 \mathrm{~m}(1.9 \mathrm{ft})-$ Scenario 13, Elevation $1.9 \mathrm{~m}(6.1 \mathrm{ft})-$ Scenario 14, Elevation $1.9 \mathrm{~m}(6.1 \mathrm{ft}) \longrightarrow$ Scenario 15 , Elevation $1.9 \mathrm{~m}(6.4 \mathrm{ft})-$ Scenario 16 , Elevation $2.0 \mathrm{~m}(6.5 \mathrm{ft})$

Point 4

Regional Corp. Buildings

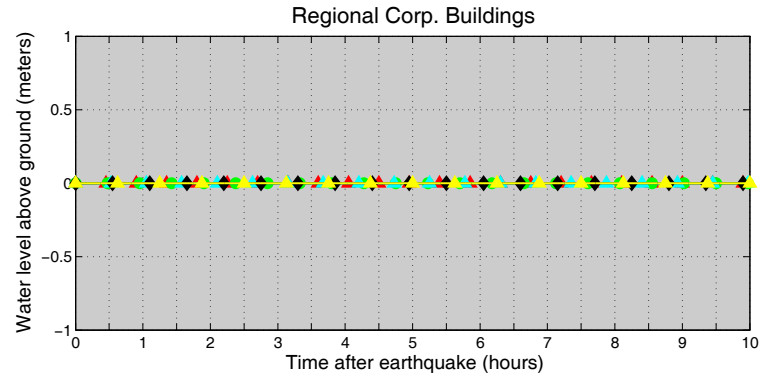

Pre-earthquake elevation $8.8 \mathrm{~m}(28.7 \mathrm{ft}$
Point 4

Regional Corp. Buildings

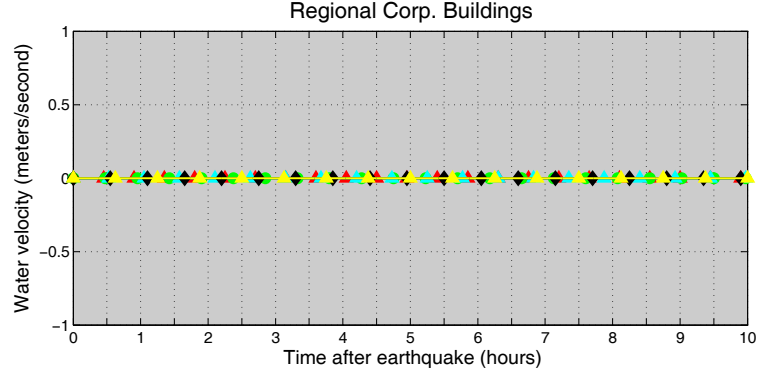

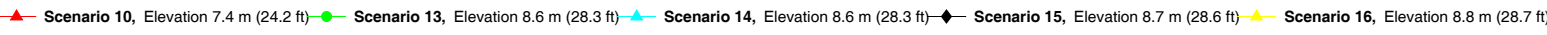

Figure B-3. Graphs showing time series of water level (left column) and velocity (right column) for selected locations in Cold Bay for scenarios 10, 13, 14, 15 and 16. For each location, pre-earthquake and post-earthquake depth corresponding to the MHHW is provided for each scenario. For offshore locations, to show the height of an arriving tsunami, the vertical datum is such that zero corresponds to the pre-earthquake sea level. Dashed lines show the water level after the tsunami. 


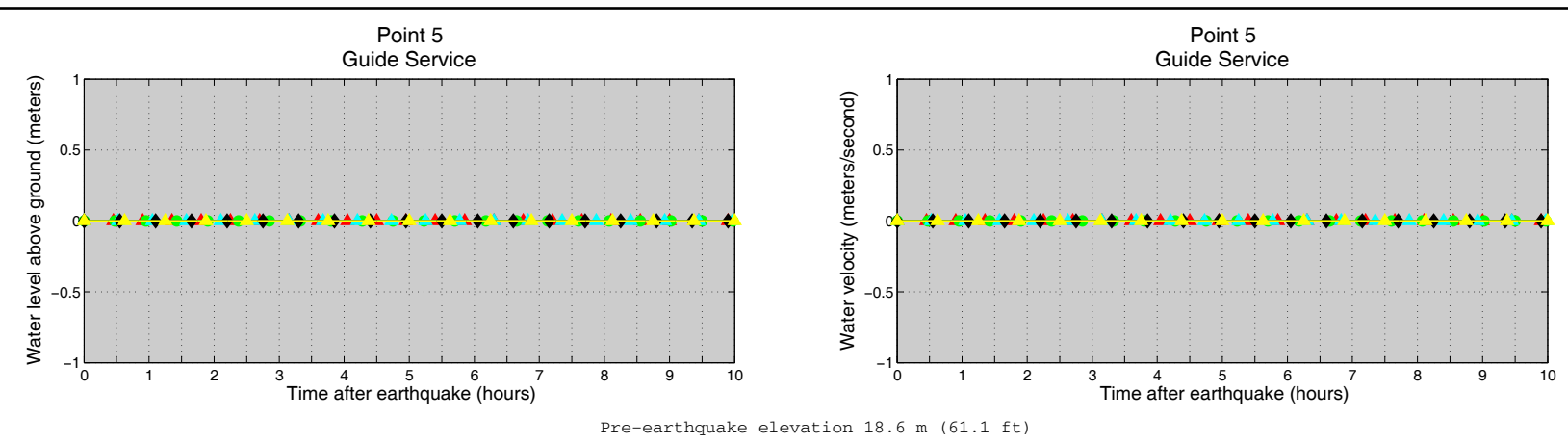

- Scenario 10, Elevation $17.3 \mathrm{~m}(56.6 \mathrm{ft})-$ - Scenario 13, Elevation $18.5 \mathrm{~m}(60.6 \mathrm{ft})-$ Scenario 14, Elevation $18.5 \mathrm{~m}(60.6 \mathrm{ft}) \smile$ Scenario 15, Elevation $18.6 \mathrm{~m}(60.9 \mathrm{ft})-$ Scenario 16 , Elevation $18.6 \mathrm{~m}(61.1 \mathrm{ft})$
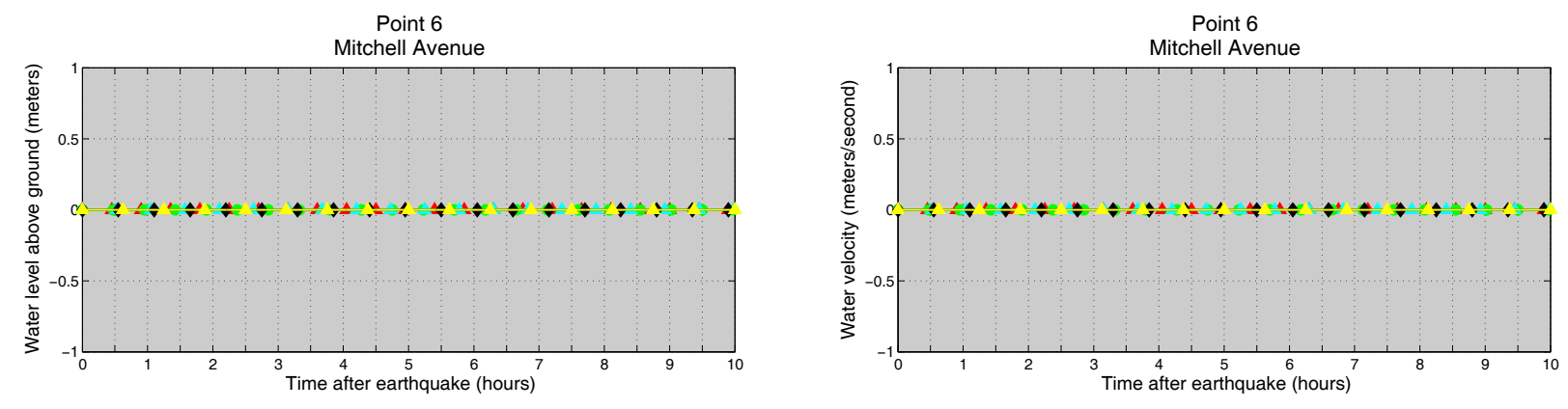

Pre-earthquake elevation $13.0 \mathrm{~m}(42.6 \mathrm{ft})$

$\_$Scenario 10, Elevation $11.6 \mathrm{~m}(38.1 \mathrm{ft})-$ Scenario 13, Elevation $12.9 \mathrm{~m}(42.1 \mathrm{ft})-$ Scenario 14, Elevation $12.9 \mathrm{~m}(42.1 \mathrm{ft}) \longrightarrow$ Scenario 15 , Elevation $12.9 \mathrm{~m}(42.4 \mathrm{ft})-$ Scenario 16 , Elevation $13.0 \mathrm{~m}(42.6 \mathrm{ft})$
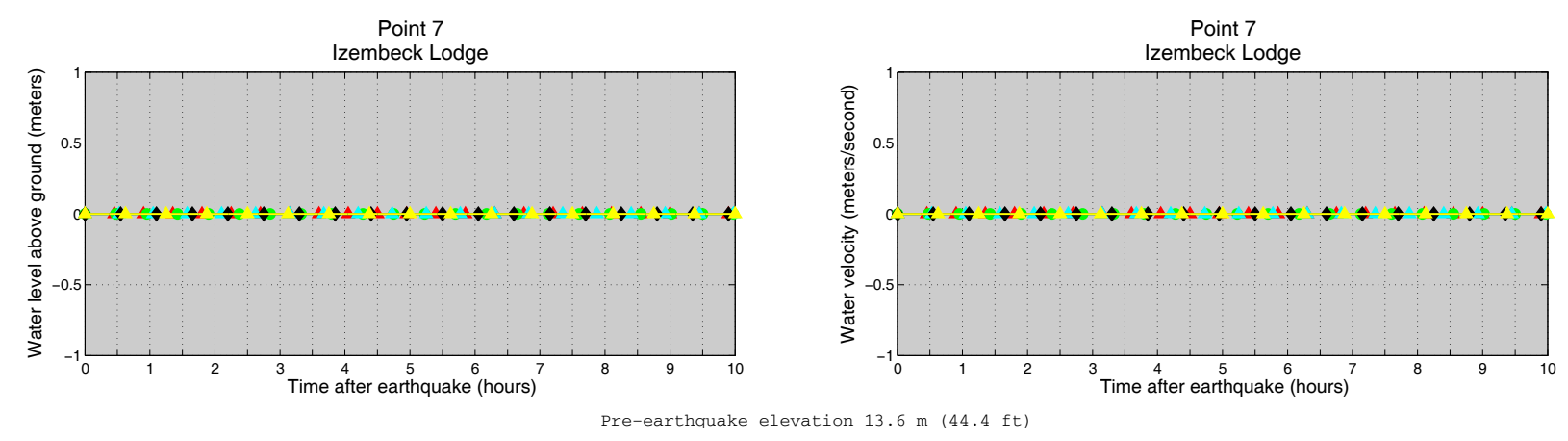

- Scenario 10, Elevation $12.2 \mathrm{~m}(40.0 \mathrm{ft})-$ Scenario 13, Elevation $13.4 \mathrm{~m}(44.0 \mathrm{ft})-$ Scenario 14, Elevation $13.4 \mathrm{~m}(44.0 \mathrm{ft}) \longrightarrow-$ Scenario 15 , Elevation $13.5 \mathrm{~m}(44.3 \mathrm{ft})-$ Scenario 16 , Elevation $13.6 \mathrm{~m}(44.4 \mathrm{ft})$
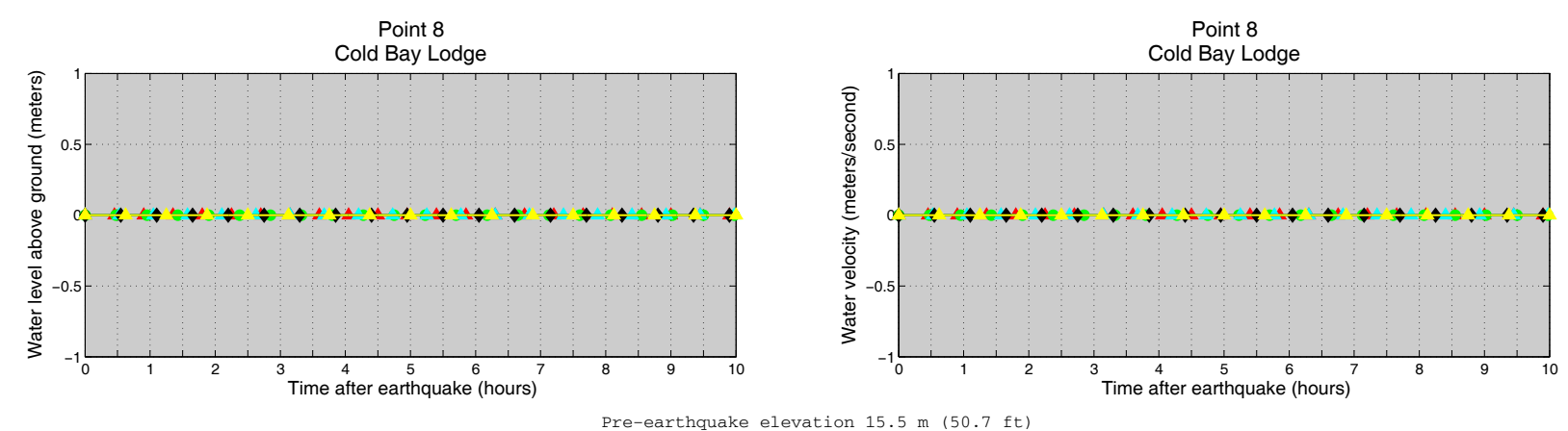

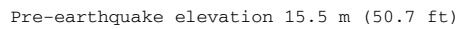

- Scenario 10, Elevation $14.1 \mathrm{~m}(46.3 \mathrm{ft})-$ Scenario 13, Elevation $15.3 \mathrm{~m}(50.3 \mathrm{ft})-$ Scenario 14, Elevation $15.3 \mathrm{~m}(50.3 \mathrm{ft})-$ Scenario 15 , Elevation $15.4 \mathrm{~m}(50.5 \mathrm{ft})-$ Scenario 16, Elevation $15.5 \mathrm{~m}(50.7 \mathrm{ft})$

Figure B-3 (cont.). Graphs showing time series of water level (left column) and velocity (right column) for selected locations in Cold Bay for scenarios 10, 13, 14, 15 and 16. For each location, pre-earthquake and post-earthquake depth corresponding to the MHHW is provided for each scenario. For offshore locations, to show the height of an arriving tsunami, the vertical datum is such that zero corresponds to the pre-earthquake sea level. Dashed lines show the water level after the tsunami. 

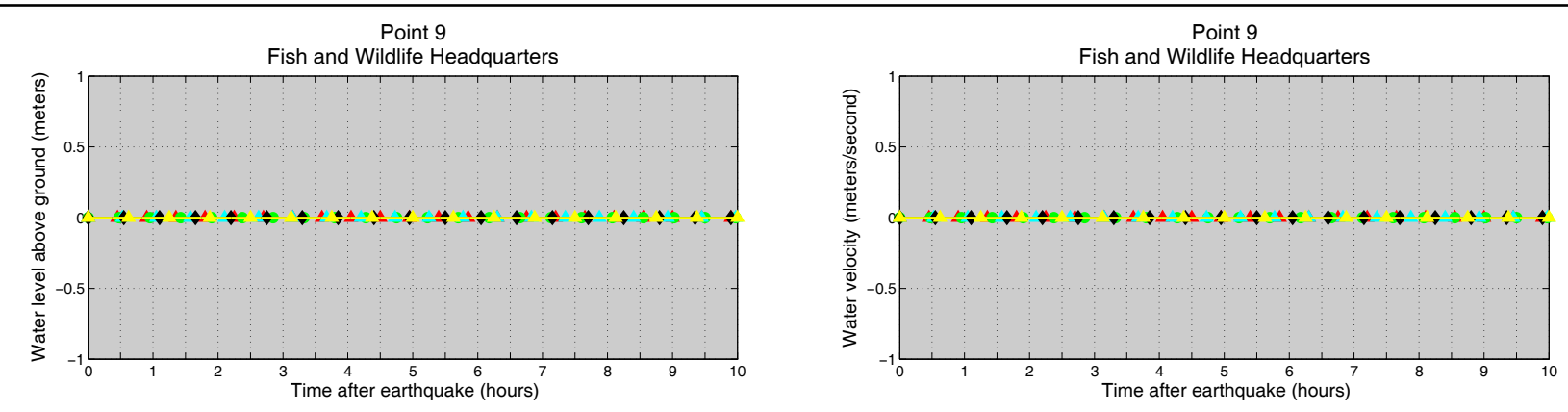

Pre-earthquake elevation $26.2 \mathrm{~m}(86.0 \mathrm{ft})$

- Scenario 10, Elevation $24.9 \mathrm{~m}(81.6 \mathrm{ft})-$ Scenario 13, Elevation $26.1 \mathrm{~m}(85.6 \mathrm{ft})-$ Scenario 14, Elevation $26.1 \mathrm{~m}(85.6 \mathrm{ft}) \smile$ Scenario 15, Elevation $26.2 \mathrm{~m}(85.8 \mathrm{ft})-$ Scenario 16 , Elevation $26.2 \mathrm{~m}(86.0 \mathrm{ft})$
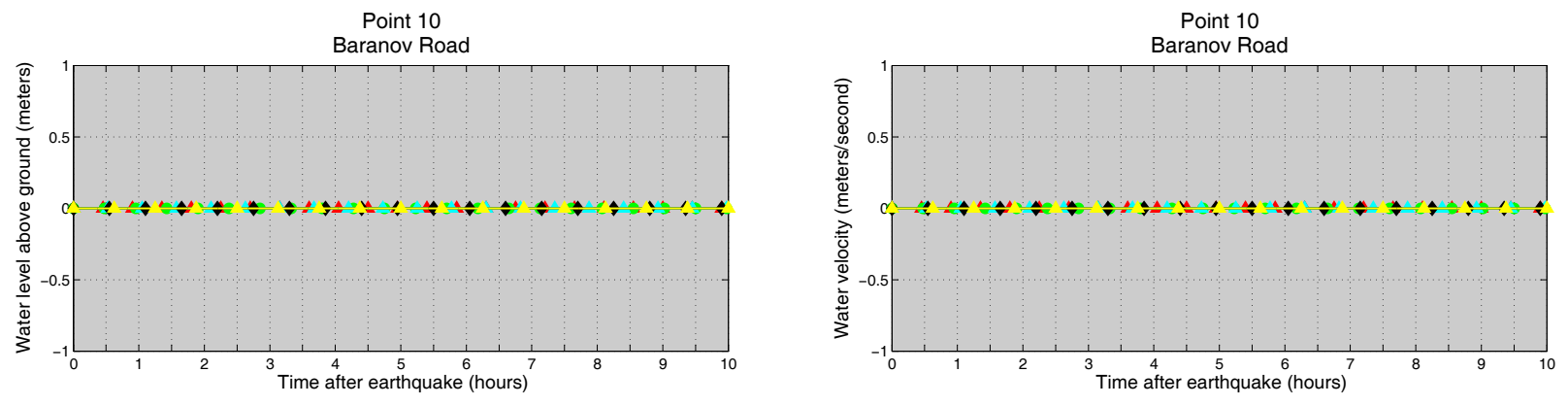

Pre-earthquake elevation $15.2 \mathrm{~m}(49.7 \mathrm{ft})$

- Scenario 10, Elevation $13.8 \mathrm{~m}(45.3 \mathrm{ft})-$ - Scenario 13, Elevation $15.0 \mathrm{~m}(49.3 \mathrm{ft})-$ Scenario 14, Elevation $15.0 \mathrm{~m}(49.3 \mathrm{ft}) \longrightarrow$ Scenario 15 , Elevation $15.1 \mathrm{~m}(49.6 \mathrm{ft})-$ Scenario 16 , Elevation $15.2 \mathrm{~m}(49.7 \mathrm{ft})$
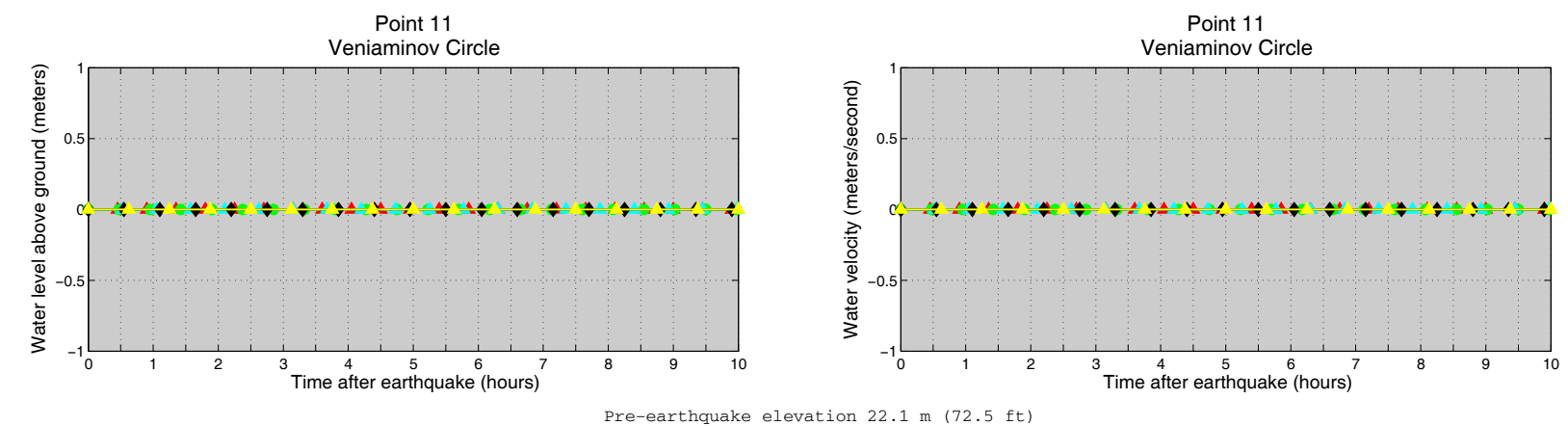

- Scenario 10, Elevation $20.8 \mathrm{~m}(68.1 \mathrm{ft})-$ Scenario 13, Elevation $22.0 \mathrm{~m}(72.1 \mathrm{ft})-$ Scenario 14, Elevation $22.0 \mathrm{~m}(72.1 \mathrm{ft}) \smile$ Scenario 15 , Elevation $22.1 \mathrm{~m}(72.3 \mathrm{ft})-$ Scenario 16 , Elevation $22.1 \mathrm{~m}(72.5 \mathrm{ft})$

Point 12

State of AK Fishery Office

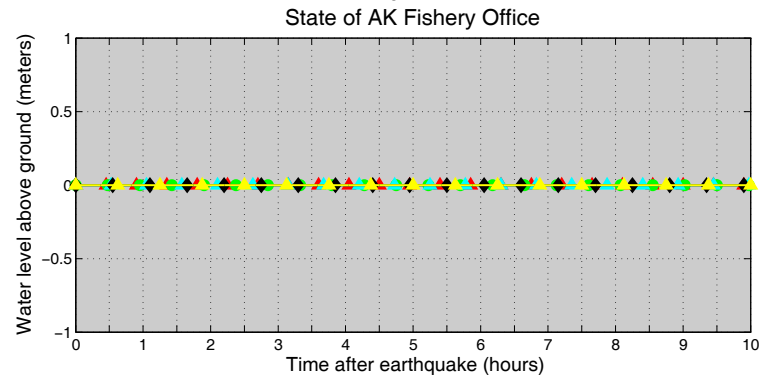

Pre-earthquake elevation $22.4 \mathrm{~m}(73.4 \mathrm{ft})$
Point 12

State of AK Fishery Office

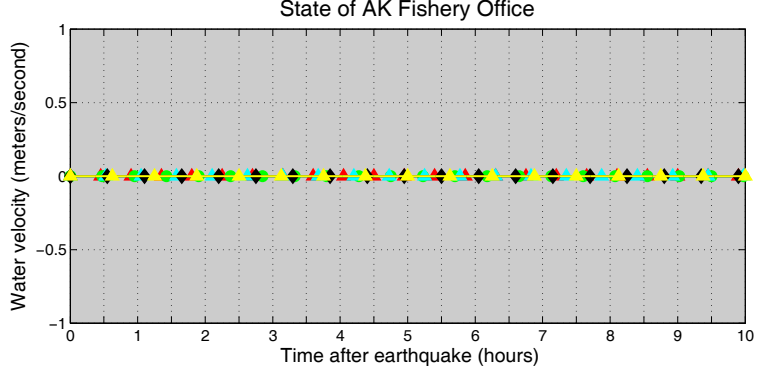

Figure B-3 (cont.). Graphs showing time series of water level (left column) and velocity (right column) for selected locations in Cold Bay for scenarios 10, 13, 14, 15 and 16. For each location, pre-earthquake and post-earthquake depth corresponding to the MHHW is provided for each scenario. For offshore locations, to show the height of an arriving tsunami, the vertical datum is such that zero corresponds to the pre-earthquake sea level. Dashed lines show the water level after the tsunami. 

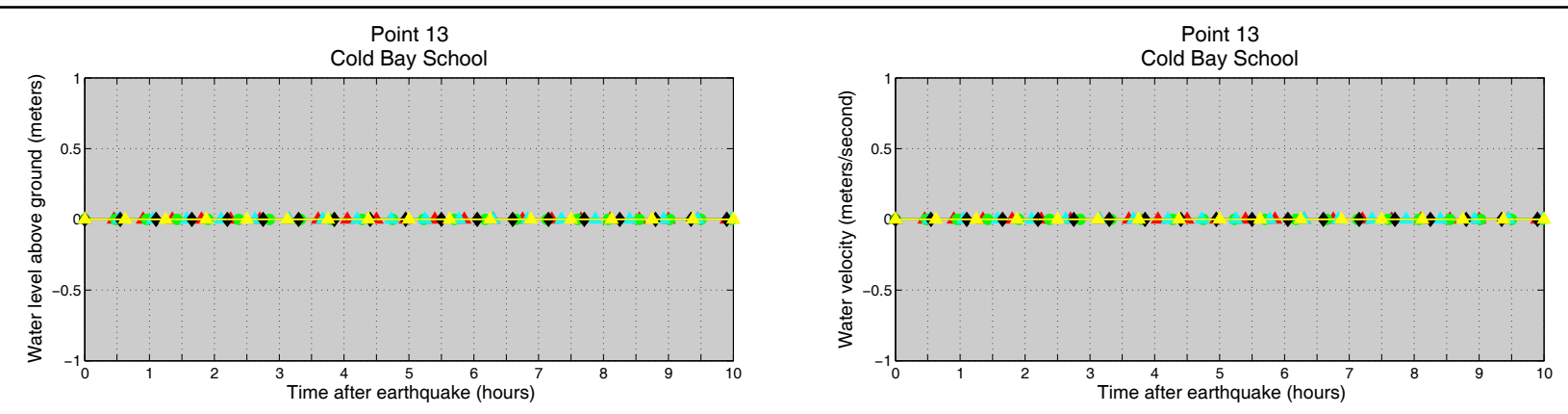

Pre-earthquake elevation $25.5 \mathrm{~m}(83.7 \mathrm{ft})$

- Scenario 10, Elevation $24.2 \mathrm{~m}(79.3 \mathrm{ft})-$ Scenario 13, Elevation $25.4 \mathrm{~m}(83.2 \mathrm{ft})-$ Scenario 14, Elevation $25.4 \mathrm{~m}(83.2 \mathrm{ft}) \multimap-$ Scenario 15 , Elevation $25.5 \mathrm{~m}(83.5 \mathrm{ft})-$ Scenario 16 , Elevation $25.5 \mathrm{~m}(83.7 \mathrm{ft})$
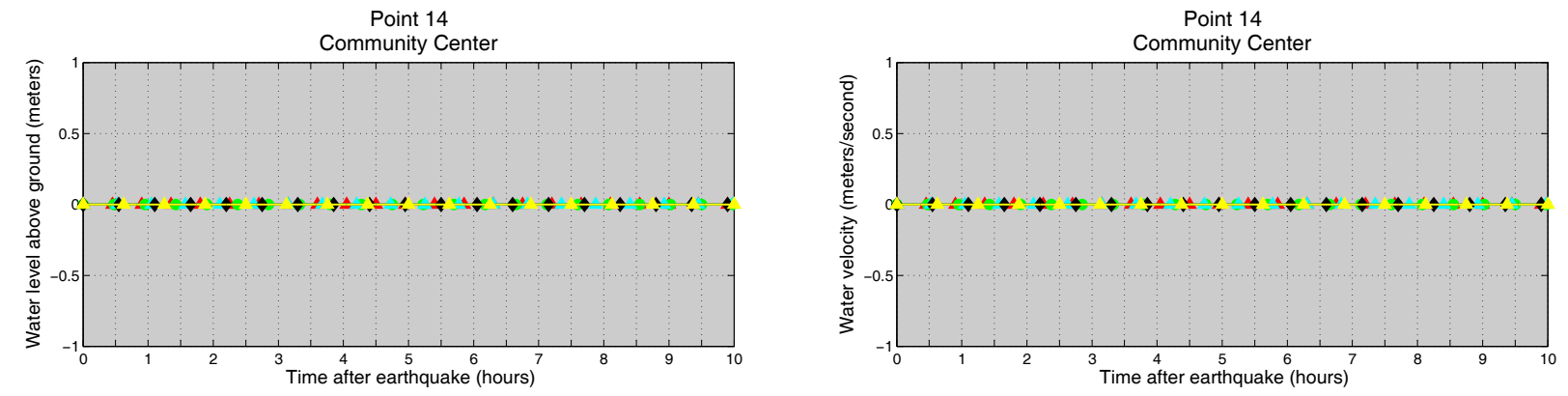

Pre-earthquake elevation $23.4 \mathrm{~m}(76.6 \mathrm{ft})$

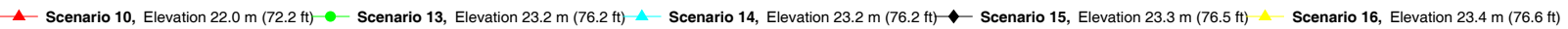
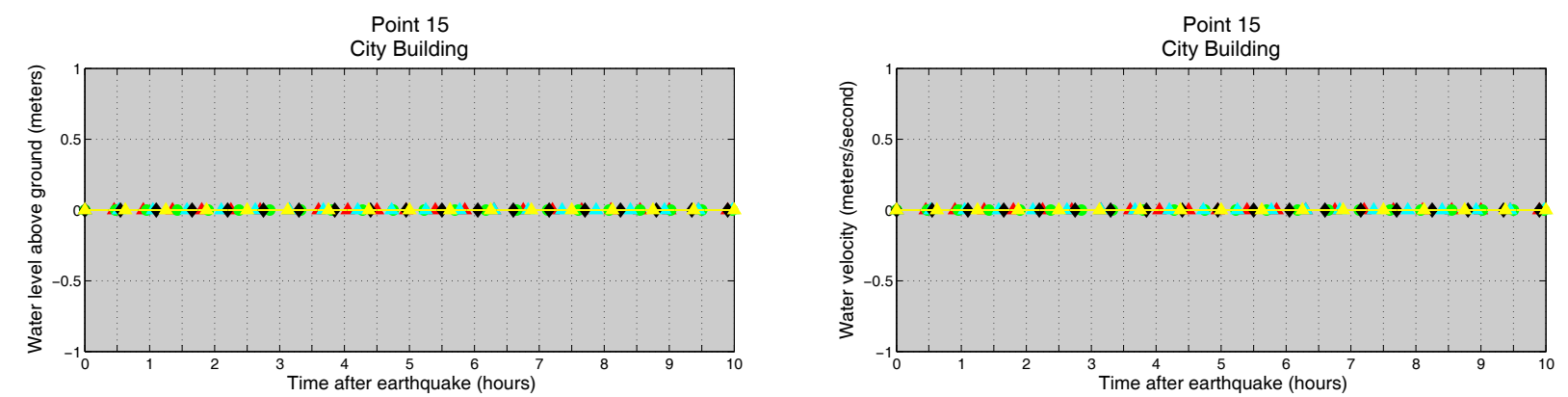

Pre-earthquake elevation $16.9 \mathrm{~m}(55.3 \mathrm{ft})$

- Scenario 10, Elevation $15.5 \mathrm{~m}(50.8 \mathrm{ft})-\bullet$ Scenario 13, Elevation $16.7 \mathrm{~m}(54.8 \mathrm{ft})-$ Scenario 14, Elevation $16.7 \mathrm{~m}(54.8 \mathrm{ft}) \longrightarrow$ Scenario 15 , Elevation $16.8 \mathrm{~m}(55.1 \mathrm{ft})-$ Scenario 16 , Elevation $16.9 \mathrm{~m}(55.3 \mathrm{ft})$
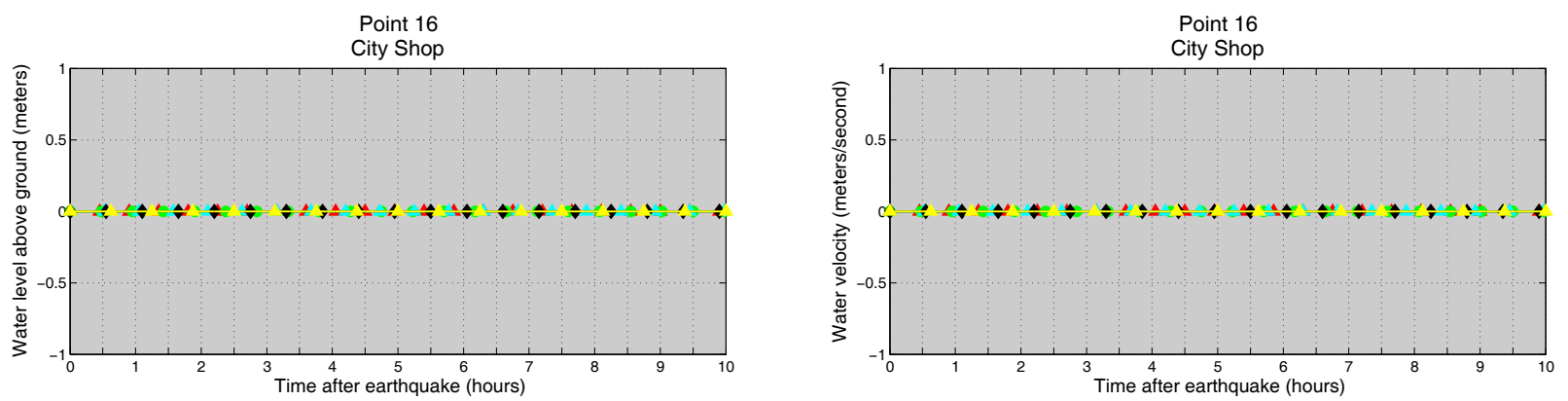

Pre-earthquake elevation $20.5 \mathrm{~m}(67.3 \mathrm{ft})$

—- Scenario 10, Elevation $19.2 \mathrm{~m}(62.9 \mathrm{ft})-$ Scenario 13, Elevation $20.4 \mathrm{~m}(66.9 \mathrm{ft})-$ Scenario 14, Elevation $20.4 \mathrm{~m}(66.9 \mathrm{ft}) \multimap-$ Scenario 15 , Elevation $20.5 \mathrm{~m}(67.1 \mathrm{ft})-$ Scenario 16 , Elevation $20.5 \mathrm{~m}(67.3 \mathrm{ft})$

Figure B-3 (cont.). Graphs showing time series of water level (left column) and velocity (right column) for selected locations in Cold Bay for scenarios 10, 13, 14, 15 and 16. For each location, pre-earthquake and post-earthquake depth corresponding to the MHHW is provided for each scenario. For offshore locations, to show the height of an arriving tsunami, the vertical datum is such that zero corresponds to the pre-earthquake sea level. Dashed lines show the water level after the tsunami. 

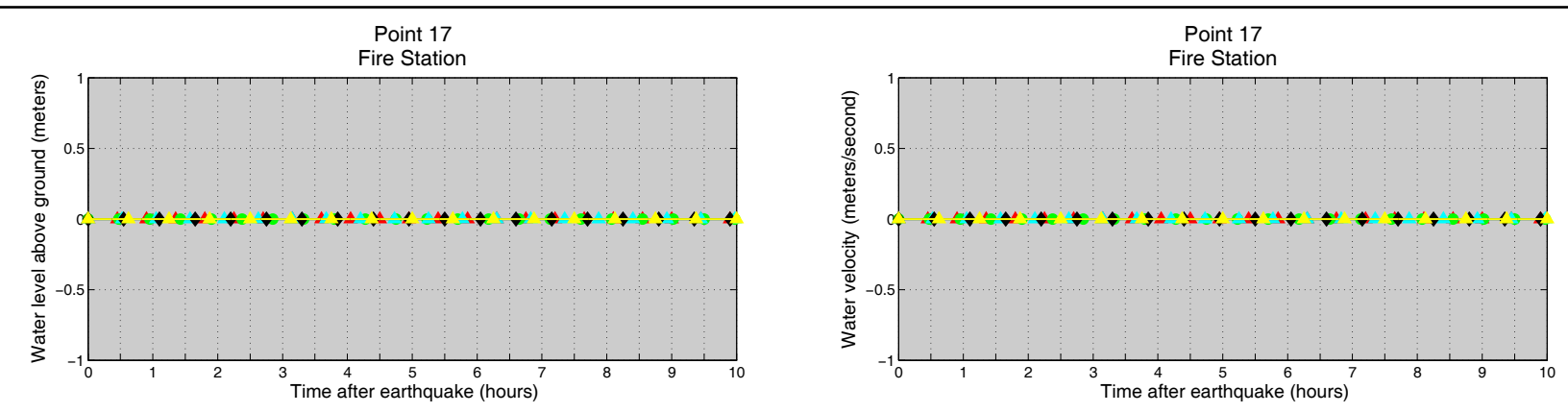

Pre-earthquake elevation $25.7 \mathrm{~m}(84.2 \mathrm{ft})$

- Scenario 10, Elevation $24.3 \mathrm{~m}(79.7 \mathrm{ft})-$ Scenario 13, Elevation $25.5 \mathrm{~m}(83.7 \mathrm{ft}) \sim$ Scenario 14, Elevation $25.5 \mathrm{~m}(83.7 \mathrm{ft}) \multimap-$ Scenario 15, Elevation $25.6 \mathrm{~m}(84.0 \mathrm{ft})-$ Scenario 16 , Elevation $25.7 \mathrm{~m}(84.2 \mathrm{ft})$
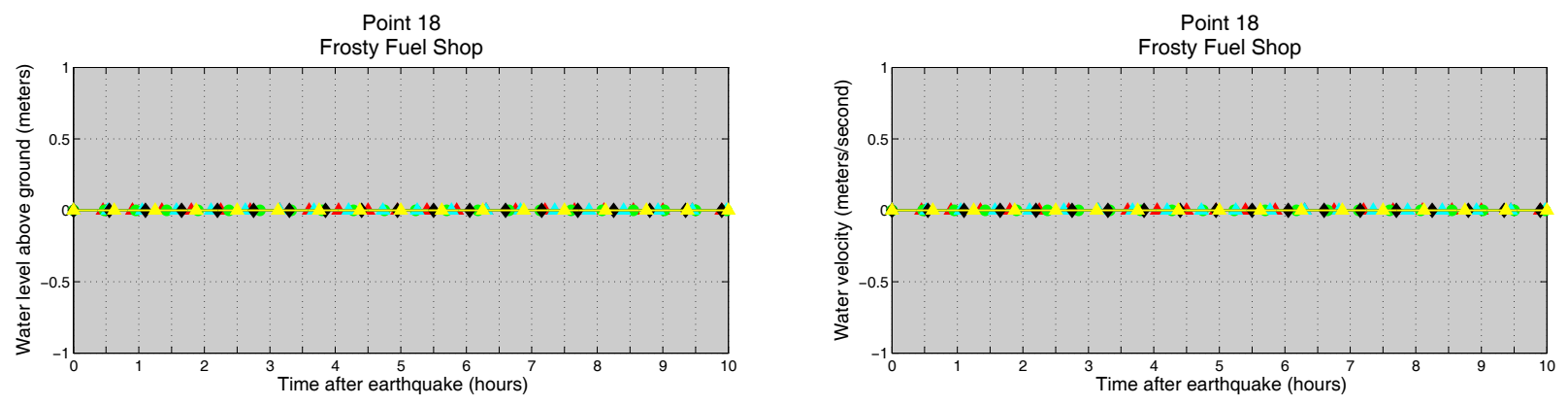

Pre-earthquake elevation $26.1 \mathrm{~m}(85.5 \mathrm{ft})$

- Scenario 10, Elevation $24.7 \mathrm{~m}(81.0 \mathrm{ft})-$ Scenario 13, Elevation $25.9 \mathrm{~m}(85.0 \mathrm{ft})-$ Scenario 14, Elevation $25.9 \mathrm{~m}(85.0 \mathrm{ft}) \longrightarrow$ Scenario 15, Elevation $26.0 \mathrm{~m}(85.3 \mathrm{ft})-$ Scenario 16 , Elevation $26.1 \mathrm{~m}(85.5 \mathrm{ft})$
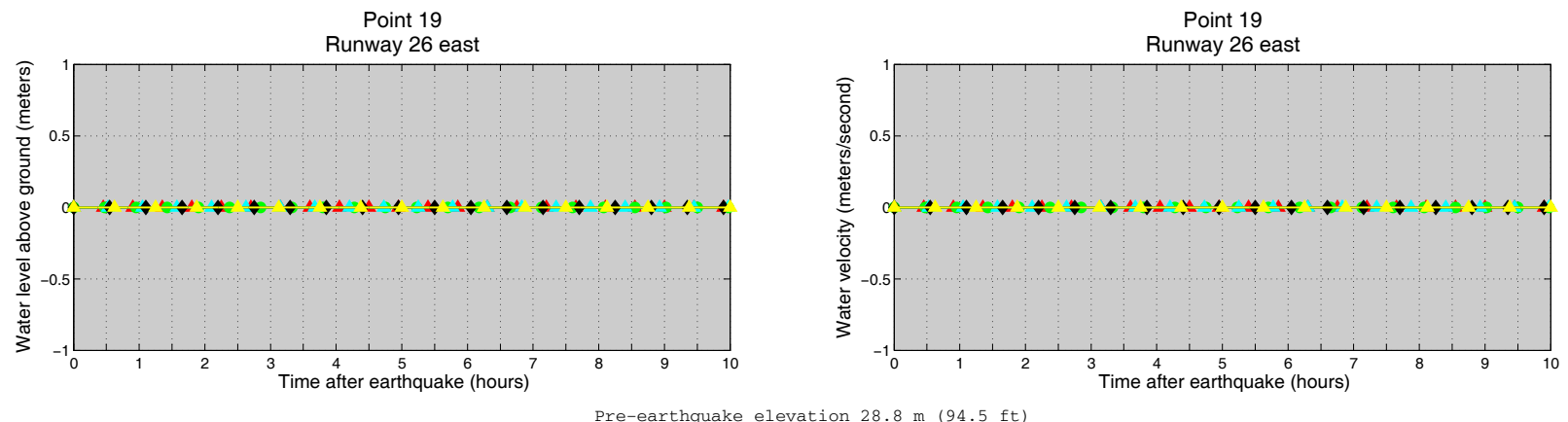

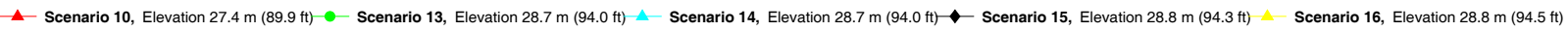
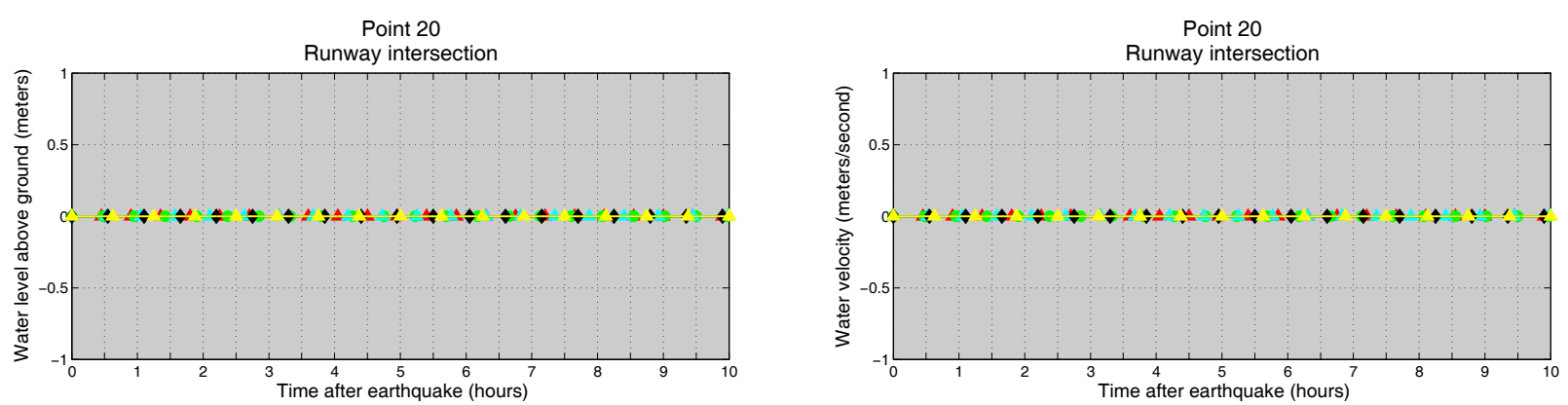

Pre-earthquake elevation $26.0 \mathrm{~m}(85.1 \mathrm{ft})$

- Scenario 10, Elevation $24.6 \mathrm{~m}(80.6 \mathrm{ft})-$ Scenario 13, Elevation $25.8 \mathrm{~m}(84.7 \mathrm{ft})-$ Scenario 14, Elevation $25.8 \mathrm{~m}(84.7 \mathrm{ft}) \longrightarrow$ Scenario 15 , Elevation $25.9 \mathrm{~m}(84.9 \mathrm{ft})-$ Scenario 16 , Elevation $26.0 \mathrm{~m}(85.1 \mathrm{ft})$

Figure B-3 (cont.). Graphs showing time series of water level (left column) and velocity (right column) for selected locations in Cold Bay for scenarios 10, 13, 14, 15 and 16. For each location, pre-earthquake and post-earthquake depth corresponding to the MHHW is provided for each scenario. For offshore locations, to show the height of an arriving tsunami, the vertical datum is such that zero corresponds to the pre-earthquake sea level. Dashed lines show the water level after the tsunami. 


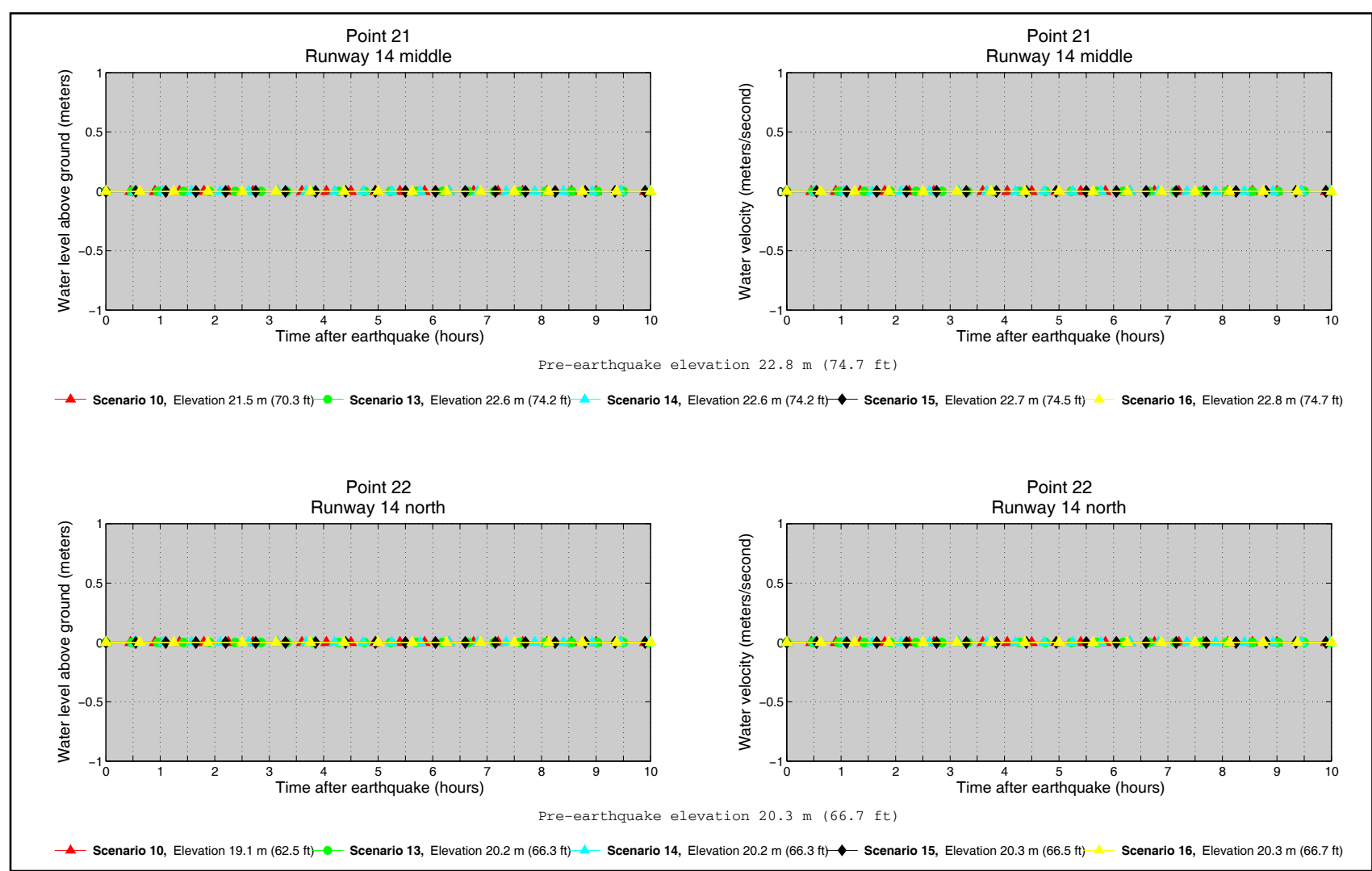

Figure B-3 (cont.). Graphs showing time series of water level (left column) and velocity (right column) for selected locations in Cold Bay for scenarios 10, 13, 14, 15 and 16. For each location, pre-earthquake and post-earthquake depth corresponding to the MHHW is provided for each scenario. For offshore locations, to show the height of an arriving tsunami, the vertical datum is such that zero corresponds to the pre-earthquake sea level. Dashed lines show the water level after the tsunami. 


\section{APPENDIX C-1 KING COVE}

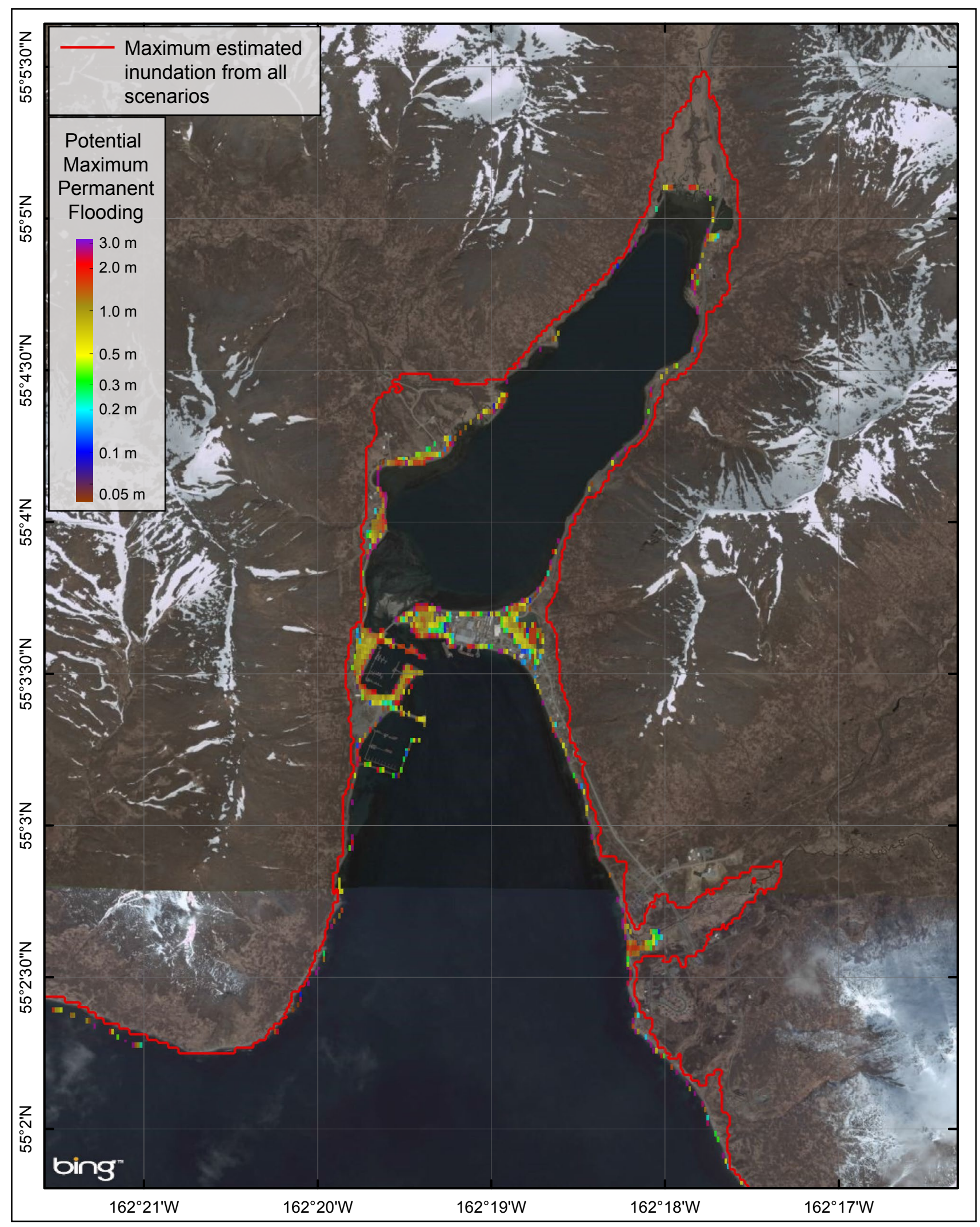

Appendix C-1. Map showing potential maximum permanent flooding in King Cove. Values of subsidence corresponding to each scenario are listed in table 2. 


\section{APPENDIX C-2}

COLD BAY

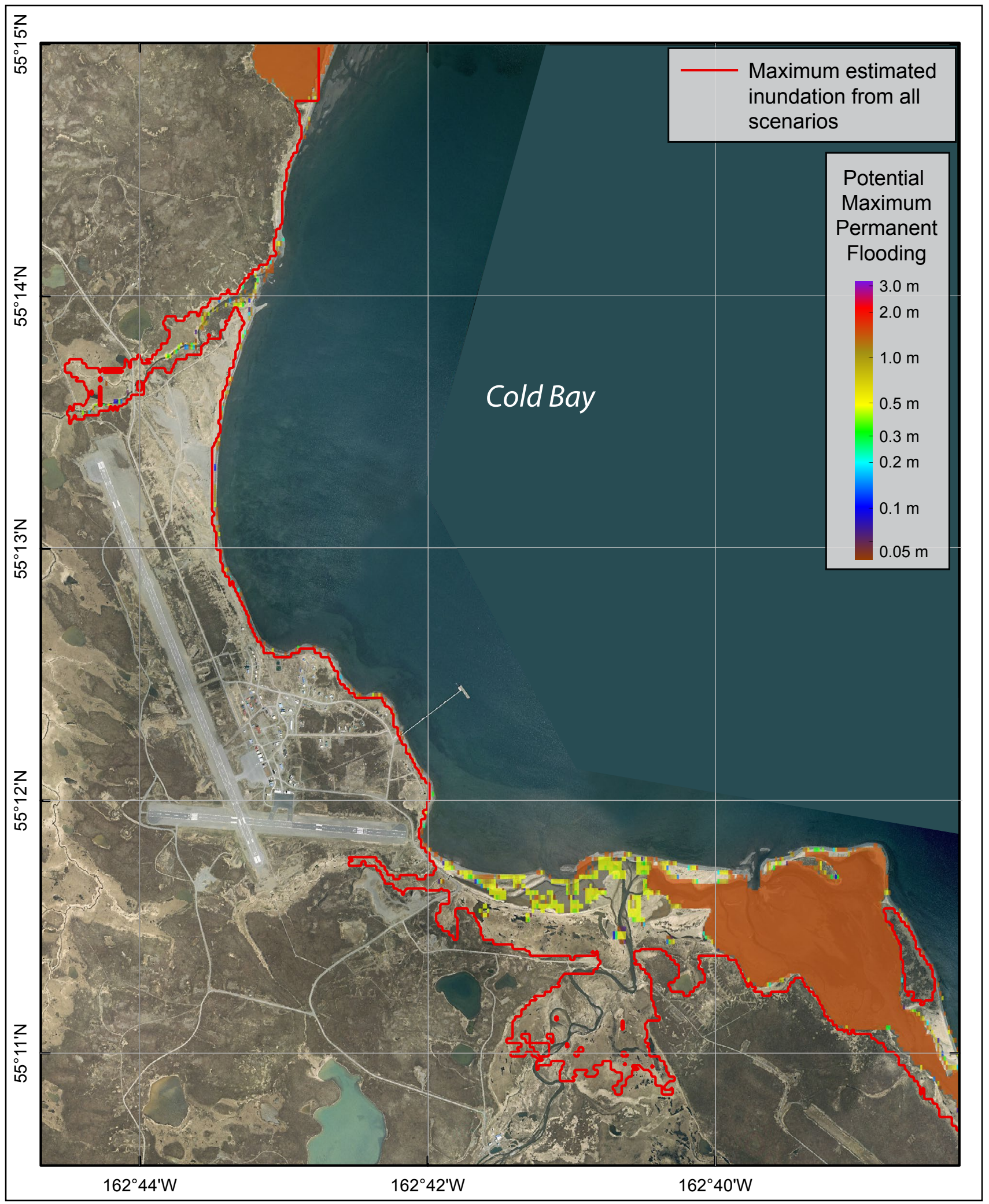

Appendix C-2. Map showing potential maximum permanent flooding in Cold Bay. Values of subsidence corresponding to each scenario are listed in table 2. 